\title{
The Seduction of Feminist Theory
}

Erin Amann Holliday-Karre

Loyola University Chicago

Follow this and additional works at: https://ecommons.luc.edu/luc_diss

Part of the Feminist, Gender, and Sexuality Studies Commons

\section{Recommended Citation}

Holliday-Karre, Erin Amann, "The Seduction of Feminist Theory" (2011). Dissertations. 168.

https://ecommons.luc.edu/luc_diss/168

This Dissertation is brought to you for free and open access by the Theses and Dissertations at Loyola eCommons. It has been accepted for inclusion in Dissertations by an authorized administrator of Loyola eCommons. For more information, please contact ecommons@luc.edu. cc) (i) $\Theta($

This work is licensed under a Creative Commons Attribution-Noncommercial-No Derivative Works 3.0 License. Copyright (C) 2011 Erin Amann Holliday-Karre 
LOYOLA UNIVERSITY CHICAGO

THE SEDUCTION OF FEMINIST THEORY

A DISSERTATION SUBMITTED TO

THE FACULTY OF THE GRADUATE SCHOOL

IN CANDIDACY FOR THE DEGREE OF

DOCTOR OF PHILOSOPHY

PROGRAM IN ENGLISH LITERATURE

BY

ERIN HOLLIDAY-KARRE

CHICAGO, ILLINOIS

MAY 2011 
Copyright by Erin Holliday-Karre, 2011 All rights reserved. 


\section{ACKNOWLEDGEMENTS}

I am eternally indebted to Pamela L. Caughie not only for her tireless work on and enthusiastic support of this project but also for her friendship, which ultimately pushed me to persist with an "ambitious" dissertation. To Anne Callahan for spending so many hours in her writing studio helping me search for just the right word to capture what I was trying to say. To Holly Laird for graciously acknowledging in my work a previous aspiration of her own and for her masterful editorial skills. And to Paul Jay for making me mindful of oppositional viewpoints. To the best friends, colleagues, sounding boards, support group, and writing group that any graduate student could ever hope to have: Natalie Kalich, Julia Daniel, Allison Fagan, Lacey Conley, Faith Bennett, and Scott Cheney. 


\section{TABLE OF CONTENTS}

ACKNOWLEDGEMENTS

CHAPTER ONE: SEDUCING FEMINISM: AN INTRODUCTION 1

Feminism on Baudrillard $\quad 1$

Baudrillard on Seduction $\quad 10$

Anti-productive Feminism: Challenging the Discourse of Meaning and Value 23

CHAPTER TWO: THE SEDUCTION OF FEMINIST THEORY 31

The Feminist who Refuses: "There is No Seduction Here" 31

The Feminine: Joan Rivière and Psychoanalysis $\quad 40$

Equality: A Guinea for Your Thoughts $\quad 50$

Subverting Identity: Or Feminism's Fictional Identity Crisis $\quad 64$

Difference and Feminism $\quad 77$

Knowledge/Knowing/Known 90

CHAPTER THREE: FROM PRODUCTION TO SEDUCTION: WOMEN AND POWER IN THE PROGRESSIVE ERA 102

CHAPTER FOUR: SELF-SPECTACULARIZATION AND SEDUCTION: DEEMPHASIZING SEX AND SEXUALITY IN MODERNIST ERA FEMINISM AND FICTION 132

Producing Sex $\quad 132$

Sexual Reform in the Modernist Era $\quad 141$

New Woman Feminism 156

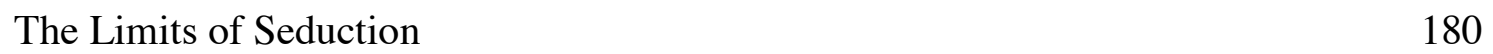

CHAPTER FIVE: POSTWAR FEMINISM: AN INTERLUDE 188

CHAPTER SIX: SIMULATING FEMINISM: POSTMODERN POLITICS AND THE LANGUAGE OF SILENCE 199

Modeling Feminism $\quad 206$

Feminism Beyond the Model $\quad 215$

Reading For Silence: Postmodern Literature and Feminism 226

CHAPTER SEVEN: CONCLUSION: A SIMULATION OF TRUTH:

RECONCILING GENDER IN THE MEDIA AND THE TRUTH AND RECONCILATION COMMISSION IN SOUTH AFRICA 253

$\begin{array}{ll}\text { BIBLIOGRAPHY } & 270\end{array}$

$\begin{array}{lr}\text { VITA } & 280\end{array}$ 


\section{CHAPTER ONE \\ SEDUCING FEMINISM: AN INTRODUCTION}

\section{Feminism on Baudrillard}

The recent death of French sociologist and theorist Jean Baudrillard in 2006 brought about a resurgence of scholarship on his work. While writing this dissertation a wealth of specifically feminist scholarship appeared including, most recently, a 2011 panel at the American Comparative Literature Association conference entitled “Rethinking Baudrillard and Feminist Theory.” In her call for papers Ingrid M. Hoofd writes: 'From Jane Gallop's 'French Theory and the Seduction of Feminism,' Meaghan Morris's 'Room 101 or A Few Worst Things in The World' to Douglas Kellner's 'Baudrillard's Affront to Feminism,' the French sociologist Jean Baudrillard has been widely condemned in the 80 s and 90 s as an anti-feminist philosopher" $<$ http://www.acla.org/acla2011/?p=425> $>$ It is true that Baudrillard has long been dismissed by feminism not only as "antifeminist," but also, by implication, as sexist, racist, and misogynist. Hoofd suggests that it is not just Baudrillard's death but his increasing relevance that makes him important to feminism: "It has become urgent to revisit Baudrillard's relevance for feminist theory in light of the latter's decreasing grip on global politics." Feminism, according to Hoofd, has become decreasingly irrelevant, while Baudrillard has come to define many theories of global politics: the media, simulation, cybernetics, and the hyperreal, to name a few. Thus, in order to regain 
political relevance, Hooft argues that it is time for feminists to reconsider their earlier critiques.

But in all of the recent feminist scholarship on Baudrillard, save for sociologist Victoria Grace's Baudrillard's Challenge: A Feminist Reading (2000), which I discuss later in the chapter, feminists have focused on Baudrillard's latter theories of simulation and the posthuman in order to maintain global relevance, forestalling any reconsideration of his earlier text Seduction (1979). In the most recent feminist text on Baudrillard, Cyborgs and Barbie Dolls: Feminism, Popular Culture, and the Posthuman Body (2007), Kim Tofoletti only tangentially addresses Seduction: “My purpose here isn't to defend Baudrillard on the topic of seduction ... rather I look elsewhere in his body of work using his theory of simulation to make sense of posthuman images in a climate characterized by the abundance of signs and the implosion of meaning" (49). Tofoletti's refusal to engage Seduction is not surprising given the fact that Seduction is commonly viewed as his most sexist work. But Tofoletti's assumption here is also that a theory of seduction is not as important as simulation for understanding today's "climate." A critical engagement with Seduction is, I argue, key to understanding just how we, as feminists, are now in the position of not only trying to "make sense" of the "implosion of meaning" but also defending our "grip on global politics." I agree that a feminist revaluation of Baudrillard's work is "urgent," but I also argue that as long as feminists refuse to engage with Seduction, they will continue to miss an unacknowledged historical strand of feminism that speaks to our continued rather than decreasing grip on global politics. Revisiting Baudrillard's theories will not make feminism relevant unless reading them 
allows us to re-imagine the history of modern feminism as already relevant. In this dissertation, I reread the history of modern feminism through Baudrillard's theory of seduction, arguing for a revaluation of feminist history and literature to highlight feminism's ongoing challenge to power and politics.

Contrary to popular feminist belief, Baudrillard's work on seduction is not rooted in a fundamental disregard for or antagonistic stance toward women. But the fact that this remains a prevailing point of view proves that feminists ban together more than most people give them credit for. Jane Gallop blacklisted Seduction in the 1980s and, since then, feminist scholars have skipped over this seminal work, usually with a nod to Gallop, ${ }^{1}$ before moving on to engage later works, such as Simulations or Transparency of Evil. ${ }^{2}$ Perhaps those feminists who use Baudrillard's later work do not recognize that his theory about the media and image culture came about as a supplement to Seduction, a lament over what Baudrillard fears is the contemporary loss of seduction through the overproduction of meaning. In failing to account for his earlier work, feminists miss the important implication of seduction as a strategy and a practice aimed at challenging the overproduction of meaning.

Jane Gallop's argument against Baudrillard's Seduction in "French Theory and the Seduction of Feminism" (1987) is many layered, but her main criticism is that

\footnotetext{
${ }^{1}$ See Kim Tofoletti's Cyborgs and Barbie Dolls: Feminism, Popular Culture, and the Posthuman Body (2007), or Rebecca Schneider's The Explicit Body in Performance (1997).

${ }^{2}$ See Rita Felski's Doing Time: Feminist Theory and Postmodern Culture (2000), and Donna Haraway's Simians Cyborgs and Women: The Reinvention of Nature (1991).
} 
Baudrillard is contradictory. ${ }^{3}$ Because contradiction is a key term in Gallop's work, in order to fully grasp the reason for Gallop's seeming dismissal of Baudrillard, it is helpful to keep in mind that her critique is informed by her earlier work. In The Daughter's Seduction: Feminist Theory and Psychoanalysis (1984), one of Gallop's main points is that in invoking any identity, indeed in utilizing any definition, we risk turning relations into comforting representations. While Baudrillard, for example, argues that "seduction" and "production" are opposing terms, in that one cannot exist where the other is found, Gallop would argue that they are relational terms and that they should be treated as such. ${ }^{4}$ In The Daughter's Seduction, Jane Gallop uses seemingly contradictory positions, feminism and psychoanalysis (insofar as feminism works against patriarchy and psychoanalysis seems to work in its favor), to model the way feminists should analyze methods and concepts relationally. ${ }^{5}$ For Gallop, even though we may oppose a particular

\footnotetext{
${ }^{3}$ Gallop is not the only feminist to critique Seduction. In Differences that Matter (1998), Sarah Ahmed argues that while Baudrillard refuses the concept of destiny, he also argues that seduction is destiny. In this way, Baudrillard seems to establish seduction as the norm. Ahmed writes, "The subject is [now] determined by indeterminacy (rather than anatomy, class, or gender). As such, Baudrillard's post-modernism can be read as a normative and positive reading of the subject" (106). Ahmed's misreading of Baudrillard is all too common in feminist theory. Baudrillard does not claim seduction as positive. Seduction is without value because it does not conform to the value of political economy. Seduction is also not a subjectivity. Baudrillard's entire work has been an effort to think beyond subjectivity (which he sees as an ideology of exclusion and hierarchy). Finally, Baudrillard does not ascribe "seduction" to humans alone but also to animals, to gambling, and to poetry. Seduction cannot be a "norm" for subjectivity.

${ }^{4}$ Gallop, as a feminist inspired by post-structuralist thought, sees all relationships as structural. But Baudrillard recognizes a need to get beyond such structures.

${ }^{5}$ For a post-structuralist reading of Gallop, see Pamela Caughie's conclusion to Virginia Woolf and Postmodernism.
} 
position, we must ask what we can learn from that position as well as what the opposing view can learn from the position we privilege. This is the only way that feminists can avoid privileging any one approach, setting up hierarchies, or exercising power. In this way Gallop privileges a double vision that sets up a dialogue and resists definition. Gallop argues that what matter are not definitive answers but questions. By keeping open a steady dialogue of questions (acting without answers), feminists can be sure that their actions will not work against them. Gallop argues that feminists must at once invoke a spirit of sameness in order to represent women's difference, in relation to men, and at the same time resist this desire over and over again.

In the first chapter of Daughter's Seduction, Gallop accuses Juliet Mitchell of separating herself from other feminists by privileging the discourse of Freud rather than engaging feminists in a conversation. ${ }^{6}$ Mitchell alienates other feminists in an effort to show that all feminists have been wrong about the "real" Freud and what his "actual" intentions were in his theory of sexuality. While Mitchell may be concerned with "bridging" the gap, she sets up a hierarchy in thinking about Freud (or what Gallop refers to as the "pre-Freudian Freud" and the "more-Freudian Freud") that results in fixed positions closing off rather than opening up dialogue. Gallop also exposes such fixed positions as fundamentally contradictory, arguing that to define terms as stable and to establish particular identities - such as the lesbian or the woman writer - would be the ruin of feminism. She uses Kristeva to make her point: "The vulgar but oh so effective trap of 'feminism': to recognize ourselves, to make of us the Truth ... so as to keep us

\footnotetext{
${ }^{6}$ I make a similar argument about Victoria Grace in my second chapter. Grace privileges the discourse of Baudrillard without engaging feminists in a conversation.
} 
from functioning as the [symbolic order's] unconscious truth" (Kristeva qtd. in Gallop). For Kristeva as well as for Gallop, the strength of feminism is that it does not mirror productivist language. Through imposing "truth" and fixed positions we make the power structures we claim to contest all the stronger.

If change within Gallop's relational model for feminism appears impossible, it is because change is very difficult to imagine within an identity structure. To re-produce the structure, to set up relations only to break them down, is still to organize and to classify, to keep "structure" as a necessity, firmly in place. To practice such a textual politics blocks any move beyond identity-politics. Gallop does explore how the structure of identity becomes constituted as reality through economic discourse. The categories she established for Kristeva, Irigaray, and Lacan - the daughter, the mother, and the prick may enable an exchange of "identities," as she argues, but beyond them they cannot move. Under this structure, feminism is chained to a never-ending process of identification and critique. The structure for identity can be played with but not discarded.

For Gallop, contradiction derives from fixed positions and connotes hierarchy and domination. It is an argument she has made against many theorists, feminist and postmodern alike. She is as likely to accuse Juliet Mitchell of contradiction as she is Lacan, Freud, Irigaray, and Kristeva. Given the fact that Gallop's work places contradictory positions in conversation, it is surprising that she seems to dismiss Baudrillard for his contradictions rather than placing him in a dialogue with particular feminists. In her essay entitled "French Theory and the Seduction of Feminism" (1987), 
Gallop rightly argues that Baudrillard asserts seduction as a truth while arguing that seduction itself is against truth. Gallop argues, "Although he announces the superiority of Seduction over truth and distinctions and categories - the book operates by setting up categories and distinctions" (112). Simply put, Baudrillard's argument is not seductive. Gallop states that her "primary" reason for her dismissal of Baudrillard is what she sees as a "rather rabid attack of feminism" (113). He is the French theorist who outright establishes "an adversarial relation to feminism" (113). Gallop is admittedly not upset with what Baudrillard says about the feminine but rather by his assertion that women should allow him to counsel them: "Baudrillard cannot seduce feminism with his truth, because he protects his truth from being seduced by feminism" (114). Baudrillard refuses to create a dialectical relationship with feminism. Like Lacan, he too is a "Prick," but one that she does not try to seduce, as she does Lacan. Baudrillard does not flirt with women. He makes over-arching generalizations about feminism without allowing for the ways in which feminism is seductive. Gallop's issue with Baudrillard, then, is not that he is contradictory but that he refuses to see feminism as itself seductive.

Gallop has laid down a challenge that many feminists have been loath to take up, preferring to reduce Gallop's critique to the idea that Baudrillard is sexist. ${ }^{7}$ In one such example, Rebecca Schneider argues that the timing of Baudrillard's theory of seduction is significant because it occurred just as women and people of color were beginning to gain access to the spheres of production: "Baudrillard might be read as representative of an anxiety born of women's entry into the realms of production" (191). One could turn this

\footnotetext{
${ }^{7}$ See, for example, Suzanne Moore's Male Order: Unwrapping Masculinity (1988).
} 
suspicion around and ask why feminists use the "just when" argument when encountering new theories that challenge them to rethink their assumption about "the realm of production." It is precisely the realm of production that is at the heart of Baudrillard's critique, not women per se. I take up Gallop's challenge, arguing for a reconsideration of Seduction, in light of his earlier work, and arguing that much of feminism is already seductive. Thus, my desire to show the ways in which feminism is seductive (in Baudrillard's definition of the term) extends Gallop's proposal from twenty years ago, a challenge that has yet to be taken up despite the recent publication of Victoria Grace's much cited book, Baudrillard's Challenge: A Feminist Reading (2000).

Victoria Grace's sociological exploration of Baudrillard's work effectively exemplifies the ways in which feminism could benefit from Baudrillard. She argues, as I do, that feminist movements for "equality" and "liberation," and their revisionist narratives that give women "subjectivity" and "identity," while insisting on the positive "differences" among women, are grounded in a productive logic and end up reproducing oppressive structures. These well-founded feminist efforts, Grace argues, have missed the important political foundations for such ideology, which Baudrillard's life work has been an attempt to explain. Using Baudrillard, Grace shows the ways in which the terms feminists use to empower women - subjectivity, identity, difference, and liberation have rhetorical beginnings in an oppressive structure described by Marx in his theory of labor and economics. According to Grace, feminists often utilize these terms without tracing the oppressive historical and political structures upon which they rely. Do feminists ever challenge, for example, the Marxist ideological premise that humans have 
needs (the naturalization of subject/object), that what separates humans from animals is our ability to produce work (the naturalization of equality/difference), or that sex and sexuality exist (the naturalization of male/female)? Grace's important contribution in reviving Baudrillard for feminism provides us with a model that not only challenges feminists to ask these crucial questions, but to understand these questions as relevant and necessary to the future work of feminism. Grace's text, though comprehensive in tracing Baudrillard's work from his early alliance with Marxist ideology to his move into and beyond Simulations, is more of a comprehensive overview of the historical progression of his theory than a critical engagement with feminism (only chapter 2 is dedicated to this aim). Thus, Grace does not show the ways in which Baudrillard has learned from feminism when developing his theory, whereas the advent of modern feminist thought, I argue, influenced Baudrillard. When engaging the work of Luce Irigaray, for example, instead of establishing a dialogue between Baudrillard and Irigaray - a seemingly important undertaking, as Irigaray is the feminist whom Baudrillard admonishes for perpetuating the productive model - Grace focuses on the "truth" in Baudrillard's reading. Although Grace acknowledges Irigary’s work as “complex," "polyvocal,” and "fragmented," and concedes that that it is impossible to impose order upon her writing (a position which ironically suggests a possibility for re-reading Irigaray as seductive), she does not explore the implications of this claim (45). In other words, Grace's important feminist defense of Baudrillard fails to engage feminist writing itself.

Grace's discussion of Irigaray relies heavily on Elizabeth Grosz's reading of the theorist: “although my aim is not to 're-present' Irigaray's work, I do wish to 
acknowledge similar reservations and qualifications [to Grotz's] in my much more restricted discussion of her [Irigaray's] ideas" (45). Among Grace's reservations are what she argues is Irigaray's search for feminine origins in the myth of Plato's cave, her assertion of an essential femininity, and her privileging of alterity and otherness: an other economy, an other speech, and an other sexuality. Grace supports Baudrillard's premise that Irigaray utilizes productive rationality - an argument, I might add, that can only be made through a "productive" reading of Irigaray, which includes a rational imposition of order, classification, and meaning upon her work. I seek to expand Grace's work by shifting emphasis away from ideas and arguments to feminist reading and writing practices. I engage critically with the work of feminists who can be understood as seductive, if not in their efforts to resist meaning making (what they say), then at least in the methodologies that they adopt in their writing (what they do). I would like to propose seduction as a reading practice, one that resists productive rationality, reasoning, classification, and meaning - particularly where these modes of thinking are rendered difficult. Like Grace, Baudrillard falls back on the productive model in admonishing feminism rather than allowing feminism to seduce him, as Gallop suggested early on. He is, admittedly, productive in his writing. But I see this more as a result of the inherent difficulty of his task rather than as reflective of his masculine anxiety.

\section{Baudrillard on Seduction}

There so are many extensive critical anthologies of Baudrillard's work and on the progression of his thought that it seems hardly necessary to engage his entire oeuvre 
here. ${ }^{8}$ It is, however, necessary to provide a brief summary of his work prior to the publication of Seduction (1979) in order to counter the belief that Seduction came about as an attack on feminism or as a theory about women - though as a theory of "the feminine," it cannot help but engage women. Seduction is an extension of Baudrillard's work on Marx, in particular his later break with Marx, and his desperate search for an alternative discourse. Baudrillard's Seduction came about as the result of an emotional and highly charged political event in 1968 that shook his political beliefs, as a former self-identified Marxist and socialist, to the core.

Seduction is not about women, really, but about proposing a challenge to rationalist, value-laden discourse. Baudrillard's writing exposes an anxiety over the (liberal/socialist) political impotence surrounding the events of May 1968, and the inability of the French socialist party and the labor unions to end the largest workers' strike in history or to assuage student uprisings. History as a productive discourse records the events of 1968 as a worker's strike in Paris that crippled the economy of France in a month, even though the "strike" itself began not with workers but with students at Nanterre University where Baudrillard was teaching. Baudrillard's account of the event, addressed in most of his works, ${ }^{9}$ focuses on the symbolic nature of the student strike

\footnotetext{
${ }^{8}$ See, for example, the most often cited texts, Jean Baudrillard: From Marxism to Postmodernism and Beyond (1990) by Douglas Kelner, Baudrillard: Critical and Fatal Theory (1991) by Mike Gane, or Jean Baudrillard: The Defense of the Real (1999) by Rex Butler.

${ }^{9}$ That I cannot recall any of Baudrillard's works that do not refer to the events 1968 points to the significance of these events for understanding his work.
} 
renouncing historical and theoretical accounts that anchor motivation in issues of class, politics, or government.

Baudrillard focuses on the conflict between students and university administrators that led to the arrest of several students at Nanterre and the closing of the school. Hearing of the news, students at Sorbonne University began to strike in an effort to reopen Nanterre. Eventually both institutions were closed and occupied by French police. Paris Lycee students and administrators became involved, and the sheer number of bodies present in the street initiated a call for riot police and police barricades. Non-union organized worker strikes soon followed and included two-thirds of France's workforce. The workers unions tried to reduce the movement to a strike against wages and consequently negotiated pay increases, but their efforts to assuage the uprising ignored any other social demand. Recalling the strike of ' 68 , Baudrillard writes: "They are the revolution, not concepts in transit. Their speech is symbolic and it does not aim at an essence. In these instances, their speech is before history, before politics, before truth, speech before the separation and the future totality ... to enclose the 'exploited' within a single possibility of taking power has been the worst diversion the revolution has ever taken" (Mirror Of Production 166-167).

The failure of the labor party or the socialist party to fully grasp the meaning of these riots led Baudrillard to the realization that social and political systems cannot account for everything that happens in society through the productive model. A concept of History, which structures society in terms of labor and economics could no longer provide an adequate explanation for social events. Rather, such discourses as these 
destroy revolutionary possibilities. As a consequence of the political impotence of the socialist system in this instance, Baudrillard gradually became anti-production, not just anti-Marxist. His allegiance to the socialist party and to Marxism suffered a huge blow, whose consequences climaxed in his writing of Seduction.

In order to understand the break that led to Seduction, we need to understand Baudrillard's relation to Marx. As mentioned above, before the political uprisings of 1968, Baudrillard was a self-proclaimed Marxist and a socialist. In one of his earliest works, Political Economy of the Sign (1972), published after the strike but written before, Baudrillard envisions the concept of "sign value" as a supplement to Marx's work on political economy. Baudrillard uses semiotics to show the ways in which the ideological concept of the "sign" is heavily invested in Marx's emphasis on "value," and thus cannot distinguish itself from or provide an alternative to value-laden economic discourse. In das Kapital (1867) Marx argues that capitalist society is structured according to a belief that value originates in the commodity when actually, historically, value derives from labor. Marx argues that all societies are structured by labor and the means to production. He defined the commodity as an object based on need, and discussed the object in terms of "use value" and "exchange value," whereby an object's use value is determined qualitatively and quantitatively through deployment or consumption. Exchange value, on the other hand, is what happens once these commodities are traded in the open market, independent of use value. Exchange value determines the owner's power to both buy products and command labor (das Kapital 128). Baudrillard recognizes that Marx's ideology of the political economy is similarly reflected in the ideology of semiotics, the 
study of how linguistic forms affect the meaning of language. For Baudrillard within the ideology of the sign, the signifier (the phonetic component of a word) corresponds to exchange value, while the signified (the concept) corresponds to use value. Use value, Baudrillard argues, was an alibi for Marx to explain the presence of exchange value.

Based on his argument about the interdependence between the ideology of semiotics and the ideology of the political economy, Baudrillard introduced the concept of "sign value" whereby objects (or commodities) do not just indicate function and utility, they are also encoded with signs that structure social practices of consumer societies. Our objects speak for and to us: "Through objects, a stratified society speaks and, if like the mass media, objects seem to speak to everyone ... it is in order to keep everyone in a certain place" (38). The values of objects structure our lives, and function as power mechanisms in order to reinforce class boundaries. Unlike the logic of use value, which emphasizes the instrument, practical operations, and utility, or the logic of exchange value, which is defined by equivalence, the market, and the commodity, the logic of sign value indicates status and difference (66). According to the theory of sign value, objects are characterized by style, prestige, luxury, and power. The sign value of an object can only be determined in relation to other objects, whereas prestige is determined according to a hierarchy of difference. Sign value, as an ideology, is an increasingly important part of the commodity and of consumption brought about by advertising and media technology.

Baudrillard argues that, in order to move outside the power structures inherent in the concepts of economic value, we must critique the ideology of political economy. The 
mythological structure that links subject, object, and need should be expelled as "naïve factuality" and "the schema of primary level psychology" (70). Marx's theory of economics is based on the ideology that humans have needs. Although the idea that humans have needs is one that is commonly accepted as true (certainly humans need food and water to survive), Baudrillard asks us to think about the way the word "need" functions in that sentence. The moment that humans say that they "need" something, they naturalize the dichotomy between subject/object: I (subject) need water (object). It was because of the word "need" that Marx was able to argue that the subject and the object are dichotomous, hardly linked at all, except through need, which constitutes their relationship. The divide between subject and object is then naturalized, and this dichotomy is conveniently itself needed in order for economic exchange (of objects) to take place according to the laws of equality (exchange value) and difference (sign value).

Baudrillard argues that the idea that humans have needs is an ideology based on hierarchy, and further exposes a desire to assert power over the material "object" and "natural" world. In order to create the autonomous subject and the autonomous object, a link between the two must be established through the concept of "need." It is the concept of use value that creates need and thereby establishes the ideology of the "subject." The structure of the commodity allows the "subject" to see himself as an individual, with identity, defined by his needs and desires - which he finds reflected in turn in the "use value" of the objects that he consumes and uses. Marx's theory of political economy and the language of semiotics are interdependent structural formations that constitute identity as dependent upon production, labor, and object- difference. This structure is responsible 
for the ideological "code," what I would like to call the "political backslash" that organizes the dichotomy as natural (subject/object, identity/difference, active/passive) based on the concept of "need." Arguing that "ideology is the process of reducing and abstracting symbolic material into a form" (14), Baudrillard wants to establish the symbolic as separate from or outside of that form. Adding semiotics to Marxist ideology exposes the concept of sign-value and use-value as similarly invested in hierarchy, expressing the value of objects in terms of difference. The structural "code" is thus held responsible for the "natural" marginalization of the "other" as object, passive and exchangeable, and as difference.

In his subsequent text The Mirror of Production (1973), written as well as published after 1968, Baudrillard formally and passionately broke all ties to Marxist thought. Marx, in failing to conceive of a possibility for social wealth and value outside of labor and production, did not offer a radical alternative to capitalism. Essential to understanding his later work on seduction, Baudrillard argued that society is dominated by the ideology and power of production as seen in semiotics, economics, and psychoanalysis. Marx assumed "production" as a natural given, a capacity of man that separates him from objects and animals. Yet the system of political economy, Baudrillard argues, "is what produces the very conception of labor power as the fundamental human potential" (31). According to Baudrillard, Marx was not describing the natural condition of man; he was creating it. In turn, history, pre-historic man, pre- industrial man, primitive man become "boomerang values" of Western society's political economy. Shattering Marx's "mirror of production" requires a two-fold process: recognizing that 
labor is not natural and rejecting the concept of identity based on the subject/object divide. Instead, labor becomes that which disinvests a body of symbolic potential by reducing it to a rational, positive, one-dimensional asset. Historical materialism, production, productive forces, mode of production, infrastructure, these concepts are all ethnocentric, belonging specifically to Western ideologies organized by bourgeois society and based on its fundamental dichotomy between man and nature. After 1968, Baudrillard had no hope for revolutions based on this productive ideology.

The primary argument in The Mirror of Production is that production is responsible for masculine economy and domination, and is used as justification for colonization: the need to impose value and meaning upon others through ideological concepts of equality and difference. For Baudrillard, the ideology of production is inherently flawed because it futilely attempts to impose meaning where none exists and thus exposes its weakness. As made evident by the futile attempt of the labor party to turn the " 68 strike into a wage issue (where Baudrillard saw a "strike for the sake of striking with no bread and butter demands"), labor and production cannot be assumed to structure social and political relations (140). Like Thorstein Veblen before him, Baudrillard argues that the motivations behind social relations include waste, prodigality, and play. That is, what drives social relations is not the means to production but the desire to have what the bourgeois have, including free time, wasteful spending, and conspicuous consumption. In The Mirror of Production, Baudrillard argues that Marx was not radical at all but instead adopted rather than critiqued productive ideology. The concept of production is not radical enough because it does not account for radical change outside the ideology of 
economic capital and labor power. Instead, Baudrillard champions the term "symbolic exchange," which he posits as "outside" the lexicon of production and economy. Baudrillard locates "symbolic exchange" among "primitive" societies, where exchange exists based on non-production, continuous reciprocity, and the limitation of goods, and is never an end or a means. Relations are formed through ritual, religion, and mythology. The gift given through symbolic exchange is not an object because it cannot be separated from the relationship of exchange, and thus breaks down the subject/object divide. Symbolic exchange is not characterized by the power of value reflected in the object, as Marx asserted, but by the separation from the self, the divesting of oneself. In locating his theory of symbolic exchange in "primitive societies," Baudrillard unwittingly undercut the importance of his work by assuming a "totalizing" and "imperialist" stance comparable to Marx's.

Seduction (1979) is a further attempt to articulate this challenge and relies on a dichotomy whereby all systems of meaning are masculine. In one sense, the position outside of this structure, which poses a radical challenge to the authority of this system, is feminine, but Baudrillard posits the word "feminine," as it relates to seduction, outside the dichotomous structure of masculine/feminine, which he says is also masculine. In Seduction, Baudrillard exposes the difficulty, the almost unavoidable trap, of attempting to think outside of the productive system. The fact that Baudrillard instantiates another "code," "masculine/feminine /feminine," in order to posit an "outside" to the system of production, is certainly contradictory because his entire argument is against the political backslash. However, for Baudrillard, to be able to theorize without contradiction is the 
first sign that a theory itself has run its course-is passé. This is an argument he makes in critiquing Marx, Freud, and later Foucault. ${ }^{10}$ For Baudrillard, contradiction is positive because, wherever contradiction is exposed, "reality" and "truth" cannot be assumed or contained - power cannot be enacted. When contradiction does not occur, we become too close to arguing for universality, and inevitably create new hierarchies of belief.

Allowing Baudrillard the admittedly generous benefit of irony (as we most certainly do for many feminists) and acknowledging that his writing is, to an extent, performative of his own theory, we can approach Seduction as a self-consciously productive discourse of anti-production rather than as instantiating an authoritative discourse.

In Seduction, Baudrillard argues that Freud and Foucault are similar to Marx in that they do not challenge the concept of sexual desire as a natural given - something that exists before discourse and before regulatory practices. Expanding on his earlier argument that "use value" constitutes "need," Baudrillard argues that the process of signification constitutes both "sex" and "sexuality." These terms are never value free. In his readings of both Freud and Foucault, Baudrillard argues that these theorists not only argue that desire is regulated and structured by discourses but also believe that sexual

\footnotetext{
${ }^{10}$ In Forget Foucault (1977), Baudrillard argues that Foucault's argument about power is productive and thus too close to the assertion of "truth." Foucault is enacting the power that he claims to be merely speaking about: "There is no vacuum here, no phantasm, no backfiring, but a fluid objectivity, a non-linear, orbital, and flawless writing. The meaning never exceeds what one says of it: no dizziness, yet it never floats in a text too big for it: no rhetoric either" (29). Foucault's History of Sexuality is, for Baudrillard, just another myth about "sex" that comes to be recognized as reality because of its consistency and its flawlessness. The problem with this kind of productive writing is that it performs a system of power that can never question the dissemination of power.
} 
desire exists prior to such systems. ${ }^{11}$ For Freud, all children start off bisexual and mature into heterosexuality or homosexuality. For Foucault sexual desire is regulated through discourses that produce heterosexuals and homosexuals as either natural or aberrant identities. While Marx takes production as a social given, Freud and Foucault assume that sexual desire, the desire for a specific sexual object, is a social given. As such, human beings are structured by how they relate to each other as sexual subjects with desire. But Baudrillard sees no natural desire, nor does he define sexuality in terms of desire for a certain sex object. Rather, he argues that what we come to think of as object desire is also created and regulated ideologically. Heterosexuality, homosexuality, bisexuality are ideologies rather than identities. ${ }^{12}$ These discourses structure how we

${ }^{11}$ In The History of Sexuality: An Introduction, Foucault exposes such a belief in the existence of sexual desire prior to regulatory discourses on sex in his discussion of the farm hand who was arrested in 1867 . Foucault writes, "At the border of a field, he had obtained a few caresses from a little girl, just as he had done before and seen done by the village urchins round about him" (31). Foucault then goes on to state that the parents of the girl found out and reported the farm hand to the authorities. The farm hand was then imprisoned and turned over to medical doctors for examination. Foucault writes, "What is the significant thing about this story? The pettiness of it all; the fact that this everyday occurrence in the life of village sexuality, these inconsequential bucolic pleasures, could become, from a certain time, the object not only of collective intolerance but of judicial action" (31). Here Foucault suggests that there is a certain "inconsequential" "village sexuality" present before the law, a pre-regulated sexual desire in which it is quite normal and natural for a farm hand to fondle "a little girl." Foucault argues, "So it was that our society - and it was doubtless the first in history to take such measures - assembled around these timeless gestures, these barely furtive pleasures between simple minded adults and alert children, a whole machinery for speechifying, analyzing, and investigating" (32). That the adults in his story are "simple-minded" and that the children are "alert" no doubt serve as a justification for his naturalization of such sexual practices.

${ }^{12}$ Foucault makes many slippages in his texts, assuming that there is sexual desire prior to the laws that regulate sex. Judith Butler addresses one of these slippages in reference to Foucault's introduction to the journals of the "hermaphrodite" Herculine Barbin where Foucault argues that while living in the convent, Herculine was able to achieve a "happy 
come to think about ourselves as possessing a natural capacity for sex and desire.

Freud was not only describing sex and sexuality he was also creating/constituting it, just as Foucault was not only describing power but also enacting it.

For Baudrillard, the moment that Freud became productive in thought was the moment he dismissed his theory of seduction. Freud's theory of seduction came about as a result of his work on female hysteria. Freud initially argued that hysteria was a result of latent childhood trauma whereby the young girl experiences sexual advances from her father, or another male relation. But he eventually, and controversially, dismissed this theory of seduction, arguing that the female hysteric was fantasizing about her father's sexual advances. Baudrillard argues that Freud's dismissal of the seduction theory was his first step to becoming productivist because Freud formally established a structural code, a political backslash between fantasy and reality in which a father would not seduce his own daughter. Freud established a reality of mythic proportions whereby female children possess a universal desire for their father, the hysteric being the pathological variant on this theme. Fathers, on the other hand, remain powerful in that no negative value is ascribed to them. ${ }^{13}$

limbo of a non-identity." Butler writes, "Foucault appears to think that the journals provide insight into precisely that unregulated field of pleasures prior to the imposition of the law of univocal sex" (Gender Trouble 125). According to Butler, Foucault suggests that the homosexual environment of the convent "was one in which this "happy limbo of non-identity' is subtly promoted" (127). Retracting his earlier statement that Herculine is participating in a practice of female homosexual conventions, Foucault "[insists] that 'non-identity' rather than a variety of female identities is at play" (127).

${ }^{13}$ Feminism, too, understands Freud's rejection of the seduction theory as a dangerous move. In an essay entitled "Hysteria and the Seduction of Theory," Martha Noel Evans understands Freud's rejection as hiding and perpetuating the abuse of young women: 
The reason that Baudrillard defines seduction as feminine has nothing to do with "real" women but is precisely because seduction is a concept that exposes the weakness of masculine, productive, realist thought through the challenge and the game: seduction is where meaning dies. In order to function as reality, the masculine order needs constant affirmation of its "truth" - "truth" that, for Baudrillard, feminists are all too willing to grant. Thus, he is not trying to deny women "subjectivity" or "sexuality" in an attempt to keep women within the roles of the "oppressed" feminine, but to show the ways that "subjectivity" and "sexuality" are products of productive discourse grounded in hierarchy, domination, and power. This is what Baudrillard means when he accuses feminism of going in the direction of the system that it claims to disavow. By arguing for a "feminine" subjectivity, a "feminine" sexuality, a "feminine" identity, we expand and propagate an oppressive structure that is based on difference and hierarchy. Even multiplying these conceptual ideologies into pluralities (identities or sexualities) does not change the underlying structure.

Baudrillard conceptualizes seduction as a challenge, a game, artifice, gambling, one-upmanship, secrecy, surface, ritual, and weakness. And nowhere does seduction assert truth. Everything from cosmetics to animals, from cards to actresses, from fairy tales to drag queens falls under his theory of seduction. What these concepts all have in

"When Freud Rejects his theory of seduction, seduction reappears in the operation of the theory itself ... Performing its function as an alleviator of the anxiety provoked by the idea of guilt of the father, Freud's new theory can be seen as a symptom at once symbolically re-enacting and concealing the abuse of young women" (76). This is a moment where feminists and Baudrillard come together, except feminists are concerned with the abuse of young women while Baudrillard locates the abuse in the political backslash. 
common is their disruption of the concepts of both meaning and value. They do not carry meaning - and they indicate no reality. Meaning is imposed upon them by productive discourse, and the meaning that is imposed exposes the inherent weakness of meaning-making systems.

Once we recognize that Baudrillard is at all times, after The Mirror of Production, against the system of production and productive thinking, then we will begin to understand that those who call him a nihilist are in effect asserting their own political position rather than describing Baudrillard's. ${ }^{14}$ This political position relies on the production of meaning and the insistence on reality to function, and this system cannot recognize alternatives because productive ideology only has the power to reproduce itself. Baudrillard has made it his life's work to find a way out of the productive model. Anti-productive Feminism: Challenging the Discourse of Meaning and Value

In 2000, Victoria Grace urged feminists to take Baudrillard seriously, and showed his relevance to postmodern feminism by exemplifying the ways in which his theory complicated everything from the subject/object divide presented by Simone de Beauvoir to Judith Butler's adaptation of the Foucaultian stance: there is no outside to power. Baudrillard's theory is critical for feminist theory to the extent that he asks feminists to challenge rather than to adopt ideologies that are grounded in power structures and have dominating impulses. He traces the historical and rhetorical beginnings of words and concepts that feminists use to empower the disenfranchised. In taking Baudrillard

\footnotetext{
${ }^{14}$ See Anthony King's essay "Baudrillard's Nihilism and the End of Theory" (1998) or Douglas Kellner's Jean Baudrillard: From Marxism to Postmodernism and Beyond. (1989).
} 
seriously, we are in turn challenged to recognize and be accountable for the concepts that we use, words historically used to discriminate against women and minorities. As Grace writes:

Baudrillard's writing on seduction shifts the inquiry from what has tended to be the dominant feminist focus - how to achieve subjecthood, agency, autonomy, desire, in alternative and non-oppressive formulations and social structures - to fix the critique more firmly on the problems inherent in this cluster of notions, and hence the underlying subjectifying impulse. Baudrillard takes this latter focus of critique further than I have seen feminist theory achieve hitherto. (153)

When the focus of feminism becomes the empowerment of women, we must critique the structures that we use to accomplish this task. In feminist writing, many words, like "subjecthood," are divorced from their historical and imperialist beginnings in an attempt to empower women. The issue is that the ideology of the word "subject" carries with it the weight of the political backslash. When we use the word "subject," we perpetuate the object as negative and undesirable and thus perpetuate masculine discourse. As long as the object becomes that which feminists fight against, we will have to continually be made aware of our own imperialist imperatives. Grace's work is an important and necessary beginning for feminist theory because she makes feminists accountable for the language that we use. And certainly it is easier to swallow Baudrillard's discourse when the importance of his theory is articulated by one who is sympathetic to and knowledgeable about feminist theory. But I would argue that the next step in this process is to raise questions about the ways in which Baudrillard's theory of seduction is evident in the writing of feminists, from Joan Rivière and Virginia Woolf in the modernist era to 
Judith Butler and Donna Haraway in the postmodernist era, rather than relying on Baudrillard as a means to exemplify the "limitations of feminist theory" (Grace 40). My objective in this dissertation is to establish seduction as a feminist reading practice of resistance to productive ideology. I argue that it is not only ignorance of certain feminists (whether she does not know them or ignores them), but also of nonproductive reading and writing practices, that allows Victoria Grace to claim that Baudrillard takes his social critique further than feminist theory. Thus, the second chapter in my dissertation will take up the method employed by Gallop in order to complicate Grace's work, to ask what Baudrillard can learn from feminism, because, I argue, Baudrillard has not offered feminism an entirely unfamiliar theory of resistance. It is rather that feminists have yet to read feminism seductively. Baudrillard's theory has allowed me to see that there is a long history of writing by feminists that constitutes a genre I term "seducing feminism." I would argue that Virginia Woolf was among the first feminists to theorize seduction in Three Guineas (though she does not name it-which already makes her more seductive than Baudrillard). Gallop does not define seduction so much as employ a feminist practice of seduction (indeed, she shows the ways in which definition is expressly unseductive or a practice of masculine economy). Drawing from the work of French Feminist theorists such as Joan Rivière, Hélène Cixous, and Luce Irigaray, contemporary American and British feminist scholars such as Judith Butler, Donna Haraway, and Trinh T. Minh-Ha, as well as Virginia Woolf, I will show, in chapter two, how feminist writing works as seduction, not meaning. It is the impossibility 
of defining a feminist discourse that enables feminism to resist the materialist rationality of a western metaphysics.

The rest of my chapters each takes a historical approach, showing how a theory of seduction, and a reading practice based on this theory, changes our understanding of feminism from the Progressive Era, to the 1920s, to our contemporary era. My third chapter addresses feminism of the Progressive Era, which asserts that woman are equal to men thorough their ability to produce. Here I argue that focusing on productive discourse systematically disempowers women. The Progressive Era is primarily imagined as a period of social and labor reform. As such, the social world was inextricably linked to the lexicon of production. Quite literally one's "social value" and sense of "self-worth" were defined in relation to the "labor" one performed and/or what one "produced." Progressive reformers sought to rationalize the labor system by investigating, measuring, and classifying working conditions in an attempt to assuage an increasingly disparate and volatile class conflict. In documenting the labor of lower-class women, reformers such as Jane Addams, Cornelia Stratton Parker, and Charlotte Perkins Gilman established feminism as a materialist practice grounded in production. Defining women's power in relation to production, however, does not further women's status in society; it only reinforces the hegemonic notion that production is the only form of power. A seductive feminist movement would attempt to break down the idea of production as power, because, as Baudrillard argues, "the more the system becomes concentrated the more it expels whole social groups. The more it becomes hierarchized according to the law of value, the more it excludes whoever resists this law" (Mirror of Production). As I show 
in chapter three there is no language in which to define women as powerful in the Progressive discourse insofar as it establishes production as the only form of social value. In this chapter, I re-read Edith Wharton's The House of Mirth (1905) as resistant to the feminism promoted by reformers such as Gilman and Parker. Wharton, I argue, negotiates a seductive alternative in her characterization of Lily Bart.

My fourth chapter addresses the modernist era and the feminist insistence on sexual equality in the early part of the twentieth century. I begin by presenting work of feminist sexual reformers such as Margaret Sanger, Mary Ware Dennet, and Helena Rosa Wright who argue that, in order to achieve full equality between the sexes, women must be allowed control over their reproductive function and enjoy sex on a par with men. However, such arguments unwittingly disempower women who do not confirm the social value of sex. In this chapter I explore the public social success of Irene Castle, an influential ballroom dancer of the 1920 s, in relation to modern fictional characters such as Lorelei Lee (Gentlemen Prefer Blondes, 1925) and Betty Lou Spence (It, 1927) in order to demonstrate that social mobility, as imagined by authors in the ' 20 s, was contingent upon a woman's ability to seduce while denying engagement in sex - that is, not through sex, but through performing femininity. I explore the significance of this shift in thinking about sexual equality for the modern woman in relation to the work of Liz Connor who, in The Spectacular Modern Woman: Feminine Visibility in the 1920s (2004), argues that the "modern appearing woman" provides a way of rethinking power outside of the terms provided by masculine discourse. 
To bridge the gap between the modernist and postmodernist eras, I include a mini-chapter, "Post-war Feminism: An Interlude," addressing the dearth of feminist scholarship on the post-war period. I argue that embracing the ideology of production has led many feminists to assume that Betty Friedan was the only serious feminist writing in the post-war era. Recognizing seduction as a feminist reading practice allows commonly dismissed feminists, such as Cosmopolitan editor Helen Gurly Brown, into the feminist canon.

My sixth chapter examines what happens to the concepts of the modern woman and modern feminism in postmodern literature within a global framework. Rita Felski claims that the recent work of feminism attempts to incorporate a global perspective on women: "By refusing to give any specific content to the feminine, the feminist philosopher hopes to avoid the charge of ethnocentrism, such a framework can include all rather than only some women"(120). While Felski acknowledges this philosophical approach as problematic because it fails to take into account the material conditions of women, I argue that the problem actually resides in the feminist adoption of the masculine stance - post-Enlightenment ideals of equality and difference need to be critiqued before theorizing a global feminist reading practice. Moreover, in our postmodern condition, the dominance of mass media with its overproduction of meaning threatens to annihilate the power of seduction, and thus silence becomes not the inverse of power but a means of resisting power's grasp. In Doing Time (2000), Rita Felski argues, "One of Baudrillard's most intriguing insights is that power works not through silencing and prohibition but rather through the proliferation and excess of 
communication. In his work, the model of the cultural code gradually gives way to the virus, invoking the endless, invasive, multiplication of endless signifiers" (139). In chapter six I explore the significance of silence as an untapped resource for the disruption of power in an era dependant on the proliferation of speech and images for the propagation of power and control. Using Maxine Hong Kingston's The Woman Warrior: Memoirs of a Girlhood Among Ghosts (1975), Isabelle Allende's The House of Spirits (1986), and J.M. Coetzee's Waiting for the Barbarians (1980), postmodern novels which explore the proliferation of speech within the current postmodern condition, I show the ways in which silent female characters function to thwart power in a global society that is contingent on the proliferation and excess of communication.

My seventh and final chapter seeks to take Baudrillard's theoretical concept of simulation as a model for rethinking the concept of power and the political in our increasingly global postmodern society. My readings of women's silence in the postapartheid hearings before the Truth and Reconciliation Commission explore the political significance of this shift from modern seduction to postmodern silence. In light of the discourse established by the TRC, where power is restored through public speech, it is important to examine the alternate ways in which women, like female characters in modern and postmodern literature, are able to find empowerment in a social and judicial system that fails to adequately represent them. By paying particular attention to the gaps and silences within the testimonies as within the novels, I raise the question of whether and when speech equals power. Reading testimonies and literature together, I seek to 
establish a new discourse recognizing the power in silence as "the immense, latent defection" from productivist discourse (Mirror Of Production 141).

My dissertation does for early twenty-first century feminism what Toril Moi did nearly twenty-five years ago for the post-second wave generation. That is, I propose to trace the political implications of feminist reading practices, to examine the strengths and limitations of three strands of feminist criticism (Marxist, Freudian, and Foucaultian), and to make my own intervention into key debates that have long gone under-analyzed. However, where Moi's critique of feminism is implicitly Marxist, mine is explicitly Baudrillardian, and where Moi stops at critique, describing rather than performing an alternative practice, I demonstrate the critical and political effects of the practice I call for through my readings of literature, film, and the TRC hearings.

Since Baudrillard's entire oeuvre is an attempt to think beyond systems of power and domination, to suggest challenges that would not establish new systems of power, how could he possibly be "against" feminism? I would agree, however, that Baudrillard has a naïve (limited and perhaps limiting) view of feminism. Had he cared to read beyond Irigaray, or indeed to see the similarities of their work (to read Irigaray seductively) rather than focusing on polarities, he might have succeeded in seducing feminism. 


\section{CHAPTER TWO}

\section{THE SEDUCTION OF FEMINIST THEORY ${ }^{1}$}

\section{The Feminist Who Refuses: "There is no Seduction Here"}

If seduction is a passion or a destiny, it is usually the opposite passion that prevails - that of not being seduced. We struggle to confirm ourselves in our truth: We fight against that which seeks to seduce us.

--Jean Baudrillard

Seduction

In her Baudrillardian analysis of feminist theory, Baudrillard's Challenge: A

Feminist Reading (2000), Victoria Grace claims that feminism's concern with the subversion of identity keeps the positivity of production firmly in place: "These concerns and foci of analysis and deconstruction are undeniably driven by an assumption of the inevitability of the economic (needs, production, value), the inevitability of the law (the bar that structures identity/difference, subject/object), even taking into account the attempts at deconstruction and re-writing from a position of a different 'difference,' and of the inevitability of power. There is no seduction here" (188). Essentially what Grace argues is that many feminists, including Rosi Braidotti, Luce Irigaray, and Judith Butler

\footnotetext{
${ }^{1}$ This year, long after I decided on the title for this chapter, I discovered an article published by Victoria Grace entitled "Baudrillard's Illusions: The Seduction of Feminism" (2008). Perhaps this was inevitable, since we are both concerned with feminism and Baudrillard. However, the subtle difference in our titles makes all the difference insofar as Victoria Grace does not actually engage with feminist theorists in her article, though she does in her book.
} 
do not theorize the political foundations for the ideology that they use. These ideologies appear logical and thus become positive foci for feminist analysis. But, in Baudrillard's estimation, all ideology is Eurocentric and thus contains hidden colonialist imperatives. Unless we address the foundations for such ideology (economics, psychoanalysis, linguistics), feminists will continue to promote the hierarchy imbedded in these terms. For example, in making identity fluid and multiple, the oppressive economic code of identity/difference still stands. Grace's insistence on the "undeniability" of what drives feminist theory indicates her refusal to be seduced by feminism. Moreover, she has cut herself off from establishing a seductive relationship with feminist discourse. Her refusal forecloses any possibility for establishing feminism as in itself seductive. Grace's inability to engage with the ways in which feminism challenges productive ideology is, in part, - and ironically - the result of a productive reading strategy that is limiting and thus limits the possibilities for reading feminism seductively.

Grace suggests that the reason feminists rejected Baudrillard's theory was the traditional definition of seduction. Grace writes, "The word 'seduction' in the AngloAmerican context, is resolutely associated with a kind of predatory male behavior bent on conquest (usually followed by the abandonment of the seduced), or alternatively a female sexual behavior designed to turn the male on his path toward evil and his downfall" (140). Certainly literature in the Anglo-American context has done much to support this traditional view, from the story of Electra in Greek mythology (who became a critical model for Freud's theory of sexuality in young girls), to Eve in the bible, to Byron's Don Juan (discussed by theorists from Foucault to Shoshana Felman). But it seems too quick 
to assume, as Grace does, that Baudrillard's use of the term is "precisely in opposition to, and a process of critique of, these accepted readings" (142). Although I do agree that Baudrillard critiques the traditional literary definition of this term, the fact that he chooses to use the term seduction, suggests that he situates himself within both literary and psychoanalytic discourses on "seduction." Placing Baudrillard in conversation with feminist Shoshana Felman can show that contemporary feminist readings of Don Juan are not so different from Baudrillard's theory.

In The Scandal of the Speaking Body: Don Juan with J.L. Austin, or Seduction in Two Languages (1983) Felman divorces seduction from its definition of sexual manipulation and "predatory male behavior" situating the term within a performative theory of language. Felman argues, "Don Juan is a myth of scandal precisely to the extent that it is the myth of violation; the violation not of women but of promises to them" (11). Locating the offence of Don Juan not in his behavior but in the structure of language, Felman argues that the words "I promise" are used to violate the meaning attached to language. Baudrillard and Felman both argue that a cognitive (Baudrillard uses "productive") view defines language as "an instrument of knowledge, a means of knowing reality" (27). But Don Juan's seduction, says Felman, is dependent on the fact that "saying for him, is in no case tantamount to knowing, but rather doing" (27). That is, the words "I promise" both have a meaning for the person who hears them, constituting a certain truth, and also state a performative act. Where women seduced by Don Juan attribute meaning to his performative act, "I promise," they grievously err. By dismissing Baudrillard as merely critical of literary notions of seduction, Grace misses the 
opportunity to read Baudrillard's definition of seduction in relation to contemporary feminists like Felman. Baudrillard writes, “To be seduced is to be turned from one's truth. To seduce is to lead the other from his/her truth" (81), precisely what Don Juan does. So while Grace is right to point to the way Baudrillard's theory of seduction differs from conventional understandings of the term, his theory cannot be completely opposed to its literary associations.

Significantly, for my argument, Grace both suggests that literary engagement is in some ways necessary for understanding seduction, and that she is limited in that regard. In her notes from the chapter subheading "The Enjoyment of Poetics," Grace writes, "I do not claim expertise in analyzing poetry ... My intention is to present Baudrillard's reflections ... to show how language might be traversed by seduction, by the symbolic" (200). Seduction travels over and through language. Grace admits that reading is integral to Baudrillard's work, but she also does not have the "expertise" necessary to engage in a non-productive (poetic) reading, though she can easily identify what a productive reading looks like, and indeed employs such a practice throughout her text. Grace argues that, for example:

A psychoanalytic 'reading' will lend itself, ... to the articulation or manifestation of the hidden meaning, silenced through each utterance. The assertion of meaning also has the function of silencing, within this framework, of repressing the unsaid, establishing a disjuncture through what is said and what is meant. (179)

Grace's assertion "there is no seduction here" is the result of productive, analytic, and interpretive reading for meaning that functions (unintentionally) to repress feminism's 
seductive potential. Specifically, Grace employs the same practice of productive reading that she accuses feminism of perpetuating.

I argue that in order to see feminist writing as seductive, we must recognize and emphasize where and when seduction occurs in discourse. My aim in this chapter is to provide examples of seduction as it occurs over and over again in feminist writing. I do not aspire to set up a hierarchy of discourse in which seductive discourse is good and productive discourse is bad, but rather to show the ways in which seduction appears in and through productive discourse so that feminists can come to understand seduction as a tool used to challenge the truth claims of productive discourse. While seduction cannot be codified as a practice - to do so would be to relegate seduction back to the productive realm - we can expose the ways in which masculine systems of production contain their own foil in and through seduction. Awareness of the ways in which productive ideologies structure social systems and recycle oppressive systems of value will lessen blind advocation of productive language.

Although Baudrillard does not describe what a seductive reading practice would look like, in his analysis language is seductive (and revolutionary) to the extent that it employs "reversible speech" (speech without the proclamation of truth), is not annexed by linguistic structures (language distributed as value through meaning and signification), and cannot return to indicate wholeness. Seductive discourse is aware of the ideological laws regarding the signification of language, how words come to have meaning through discourse, and works to expose the artifice behind such signification, by using non-sense signifiers - words, images, and concepts emptied of significance and value. When 
describing the ways in which seduction functions in culture, Baudrillard often turns to readings of literary texts such as Kierkegaard's "Diary of the Seducer" (1843), Baudelaire's "In Praise of Cosmetics" (1894), or the 1965 film and novel The Collector. In one reading Baudrillard turns to a fairy tale: the story of a boy who finds a fairy and asks it to grant him his wishes. The fairy agrees on the condition that the boy "must never think of the color red in the fox's tail" (74). The boy replies, "is that all?" and goes out in the world to search for happiness (74). What happens next is what is, perhaps, most expected. The boy begins to see the color red in the fox's tail everywhere he goes and in his dreams. Baudrillard writes,

Despite all his efforts he cannot make it disappear. He becomes obsessed with this absurd, insignificant, but tenacious image, augmented by the spite that comes from not being able to rid himself of it. Not only do the fairy's promises not come true, but he loses his taste for life. Perhaps he dies without ever having gotten clear of it. (74)

This story demonstrates, for Baudrillard, the power of any signifier that is insignificant. The fairy in this story is presented as mischievous, rather than good, as she is quite aware of the fact that the boy's mind will be attracted to a place devoid of significant meaning. The child was not on his guard because of the seeming insignificance of the color red in the fox's tale. If the fairy had asked the boy not to engage in something serious or of significance, the boy would have been more likely to succeed. It is, according to the theory of seduction, the meaningless signs that consume us much like the front of a door marked: "this door leads to nowhere." You must absolutely open it just to see. What is crucial here is Baudrillard's analysis rather than the actual story itself. For one could argue that the color red in the fox's tail does have meaning in that the color red contains 
both a signifier, red, and a signified, the color that comes to mind. The color red becomes emptied of meaning only in relation to the way in which Baudrillard reads the story. He urges the reader to recognize that absurd and artificial signs rule the world to a greater degree than logical ones because of the social and political imperative to create significant meaning.

To understand feminist writing as seductive would, in my view, involve a reading strategy in which feminism and feminist theory can be recognized as breaking down the coded system of meaning production through the dissemination of both meaning and value. A seductive reading practice will highlight the presence of signs without referents, eclipsed signs, absurd and non-sensical signs in feminist writing, not to provide meaning for these signs but to explore the ways in which these empty signs function in the text to reverse "irreversible," or fixed, ideologies. I will argue that where feminism empties words and gestures of meaning by both wearing them out and tiring them, as Virginia Woolf does with "the mulberry tree" in Three Guineas, and when feminism employs neither productive value, nor opposition to that value, as Judith Butler does with "the clown" in Undoing Gender, seduction comes into play. Seduction is not an either/or proposition but spaces in-between. For Baudrillard, seduction "takes from discourse its sense and turns it from its truth" (55). I would argue that much feminist thought has been dedicated to this very task. Seductive reading is first and foremost a reading of enjoyment, not reading for knowledge. For Baudrillard, it is enjoyment that derives from language that "shatters the fundamental laws of the human word" (Symbolic Exchange and Death 197). Thus seductive reading "requires" a reciprocal enjoyment of feminist 
theory. Seduction requires duel/dual participation on behalf of the seducer (writer) and the seduced (reader). Yes, it is a game, a game of risk that always implies a death, either of seduction through the institution of power, the insistence upon productive meaning, or of productive value by disseminating power structures through seduction and artifice. For Baudrillard, seduction emerges victorious because the concept of death is a seductive act: death has no particular meaning.

What follows, then, is a critical engagement with feminists who can be read as moving beyond the productive model when imagining the means of feminism and feminist theory (means, not goals, which implies finality). I have structured this chapter into subsections that explore popular productivist ideologies with which feminists have continually grappled: issues of the feminine, equality, identity, difference, meaning, and knowledge. Necessarily, as these terms are heavily imbricated in rubrics of power and domination, they bleed into one another. Although the feminists I have chosen vary in terms of historical time period, political affiliation, and geographical location, they share a common desire to imagine an "outside" to the social structures of power and domination in which they are heavily immersed - structures, which they realize also are imaginary, systems that rely on the propagation of their discourses to survive. The outsider position realizes that feminists cannot "know" women except in relation to their historical representation in and through masculine discourse. Thus, the challenge for these feminists is to imagine a space outside the representation of women. This entails not the perpetuation of new knowledge about the nature and value of women but a radical "unknowing" of women - unknowing in relation to the productive discourse of value. 
My hope is to expose the textual politics whereby feminism works as seduction, what Victoria Grace defines as, "that movement that removes from the realm of the visible, that vaporizes identity, and is marked by ambivalence" (141). Although Grace and I both acknowledge the benefits of Baudrillard's work for feminism, I recognize certain continuity between the two, while Grace perceives a divided duty, implying Baudrillard does it better. I hold to the belief that feminists have posed a radical challenge to productive ideology. While Baudrillard provides a discourse that helps recognize seduction, it is feminists who interest me here. My goal is to help us recognize the benefits of seduction as a feminist reading and writing practice.

My principle of selection often, but not always, includes re-reading the same feminists that Grace engages with (Haraway, Irigaray, Butler) in order to foreground seduction as a reading practice. Where I differ from Grace's engagement with feminism, I elevate and give attention to feminism. Grace claims that she is not engaged with the work of feminists whose standpoint comes close to that of Baudrillard "because [she has] not found them" (5). I argue that, in order to discover similarities between Baudrillard's theory of seduction and the work of feminism, productive reading practices must be abandoned. I venture back further into the epistemology of feminism in order to argue that the feminist theory Grace does engage is influenced by that very seductive history. It is not necessary to find explicit references to Baudrillard's theory in feminist writing to recognize feminism as seductive - what is required is a close attention to feminist language. My intention in this chapter is to argue that feminism is radical insofar as it exposes the vulnerability and weakness of power structures that are articulated through 
productive ideology. Seduction, as a feminist reading practice, can never and would never attempt to assert power except in relation to the dissemination of productive discourse (even or especially where this method is employed by prior feminists). It is also a strategy that does not fear contradiction. As Donna Haraway imagines, for lived possibilities, in her feminist cyborg manifesto, “A cyborg world might be about lived social and bodily realities in which people are not afraid of ... contradictory standpoints" (154).

\section{The Feminine: Joan Rivière and Psychoanalysis}

All masculine power is a power to produce. All that is produced, be it production of the woman as female, falls within the register of masculine power. The only, and irresistible power of femininity is the inverse power of seduction.

--Baudrillard

Seduction

"Seduction" as an "ideology" did not originate with Jean Baudrillard. Though he is perhaps the first to name it, he does not own it. To trace a mythical origin story for the theory would begin with French psychoanalyst Joan Rivière. Rivière's essay on womanliness is conspicuously lacking from Victoria Grace's text on feminism and Baudrillard. I say "conspicuously" because, when defining seduction, Baudrillard specifically draws upon Rivière's work, claiming:

Joan Rivière in 'Feminité Sans Mascarade' makes a fundamental claimone that contains within it all seduction: 'Whether femininity be authentic or superficial, it is fundamentally the same thing.' This can be said only of the feminine. The masculine, by contrast, possesses unfailing powers of discrimination and absolute criteria for pronouncing the truth. The masculine is certain, the feminine is insoluble. (10-11) 
Baudrillard's theory thus both draws from and is influenced by the seductive work of Rivière, a feminist who gave unfailing proof of seduction in her own writing. Rivière's thesis in "Womanliness as Masquerade" (1929) is that "women who wish for masculinity," which she defines as authority, independence, and power, "put on a mask of womanliness to avert anxiety and the retribution feared from men" (303). Rivière's study explains that intellectual pursuits before 1929 were exclusively the province of an “overtly masculine type of woman" (303). However, at the time of her writing, this is no longer the case. Rivière is particularly interested in describing a new kind of woman, one who successfully enters the professions while still assuming the feminine roles expected of her (in terms of dress, domesticity, and maternity). Many feminist scholars read Rivière literally and conclude that women in positions of power use femininity to deflect masculine anxiety. ${ }^{2}$ Hillary Robinson assumes that Rivière is expressing anxiety over her own precarious position as a female psychoanalyst in a male dominated field, such that "woman has no choice but to respond to [phallocentric] structures by enacting the masquerade" (Robinson 33). Judith Butler defensively argues that Rivière uses psychoanalytic tools to mask female homosexuality: "[She] clearly, begins with set notions about what it is to display characteristics of one's sex, and how it is that those plain characteristics are understood to express or reflect an ostensible sexual orientation" (Gender Trouble 64). Butler suggests that Rivière is using the tools of masculine psychoanalytic thought as a means to simultaneously enact and mask her own power to define. Or, to put it more bluntly, Rivière invokes psychoanalytic topology "as if it were a

\footnotetext{
${ }^{2}$ See for example "Fantasy Echo: History and the Construction of Identity" by Joan W. Scott.
} 
phallic shield" (66). But supposing that we read Rivière's essay on "womanliness" seductively, as Baudrillard's comment invites us to do, not as an affirmation of masculine analytic thought, but as a radical challenge to productive thought? I would argue that Rivière's essay, as well as her theory of "womanliness," can also be read as performative, thus opening up rather than closing off possibilities for Rivière's text.

What would first have to be acknowledged is that masculinity and femininity are, in Rivière's discourse, not just the expression of sexuality but also a “mode of life" (304). "Sex" is a means, a method, and an approach. When she argues that this "type" of woman "appears to fulfill every requirement of complete feminine development," in that she is an excellent house wife and mother, enjoys fashion, "maintains social life," "assists culture," and also fulfills her professional duty as well as the "average man," Rivière is not necessarily suggesting a sexual goal or finality in development, as in "this woman is complete in her socially sanctioned feminine development." Rather, because "sex" is understood as a mode or a means, "a complete feminine development" suggests that this kind of woman has found an approach to life that allows her to be successful, a means to mobility. This approach is "feminine" or what Rivière terms "womanly," and, as we know from the title, the approach is defined as a "performance," a practice of "masquerade."

Indispensable in Rivière's analysis, and to my reading above, is her assertion that this kind of woman defies classification. She is at once a type, and cannot be relegated to a type - a contradictory tension that remains unresolved throughout Rivière's essay. Rivière writes, "It is really a puzzle to know how to classify this type psychologically" 
(304). This type of woman resists both meaning and definition. We have no

psychological classification for her. In a manner of speaking, Rivière is taking a huge risk in this essay because in order for productive discourses, like psychoanalysis, to maintain cultural, social, and medical authority, classification and meaning making are indispensable. Why, then, this hesitation, this puzzle? Perhaps Rivière is posing her own challenge to a colleague, fellow psychoanalyst Ernest Jones.

In the introduction to "Womanliness as Masquerade," Rivière eulogizes Jones for "one of the most important contributions" to the subject of the sexual life of women (103). ${ }^{3}$ Specifically, she says, "as always, he throws great light on his material, with his particular gift of both clarifying the knowledge we had already and also adding to it fresh observations of his own" (303, my italics). Especially significant in Rivière's review of Jones is the repetitious use of production metaphors to describe Jones' gift for psychology. In Forget Foucault, Baudrillard explains, "the original sense of 'production' is not in fact that of material manufacture; rather, it means to render visible, to cause to appear and to be made to appear" (37). Jones is productive to the extent that he throws great light. He clarifies knowledge. And yet, even with his indispensable observations, Rivière suggests the presence of a type of woman who seemingly resists all of Jones'

\footnotetext{
${ }^{3}$ Rivière is responding to an essay Jones wrote in the International Journal of PsychoAnalysis (1927) entitled "The Early Development of Female Sexuality" in which Jones differentiates between the paths of homosexual and heterosexual women. Addressing Karen Horney's charge that male psychoanalysts assume a limited phallocentric bias in their analysis of female sexuality, Jones attempts to widen the scope of analysis to include female homosexual "types," distinguishing between women who "retain their interest in men" and "ceaselessly complain of the unfairness of women's lot" as opposed to those who "have little or no interest in men" and "whose libido centers on women" (Psychoanalysis and Female Sexuality 30).
} 
classifications, even with his 1927 addition of "intermediary types." In Rivière's introductory notes on Jones's work, her attention and praise, is a conscious performance of the masquerade. It is not so much that Rivière's masquerade highlights the precarious nature of her position of power as she explicitly challenges the position of power, the ability to know and to classify based on observation. If Rivière assumed an antagonistic approach to Jones, or if she deliberately set up an opposition to him, her opposition would instantiate another "truth," and thus she would perpetuate productive power.

Rivière argues that her "type" of woman is successful, has wonderful personal relationships, great sex, "a high degree of adaptation to reality," and is in good standing with nearly everyone (304). Rivière neither asserts that her type of woman is socially lacking, nor does she assert a social reality that is static or unchanging. The fact that this new woman is described as possessing the ability to change, to fit new circumstances, to modify herself, and to survive also suggests that the reality experienced by this woman is not of her own making. She does not "accept" reality, she adapts to it. Yet, according to Rivière, this "stability was not as flawless as it appeared" (304). For example, in one case a woman, whose job consisted of propaganda, writing, and speaking, felt extreme anxiety after every public performance. After a particularly difficult speech, the woman sought confirmation from men through what Rivière calls "veiled" "flirting or coquetting," seeking compliments about her performance while resisting the suggestion that she was in any way unequal to men, rejecting the idea that she was subject to their judgment or criticism (305). Rivière explains her difficulty in using Jones' classification for this type of woman as such: 
In this she clearly corresponded to one type Ernest Jones sketched: his first group of homosexual women who, while taking no interest in other women, wish for 'recognition' of their masculinity from men, and claim to be the equals of men, or in other words, to be men themselves. Her resentment, however, was not openly expressed; publicly she recognized her condition of womanhood. (305)

According to the classifications established by Jones, this woman would be classified as a "homosexual" woman by nature of the fact that she sees herself as equal to men (she has power too) and wants recognition of her masculinity (power) from other men. However, this woman disrupts his classifications at precisely the point where she would also have to look, dress, and act masculine. The woman neither asserts nor espouses masculinity. Using Rivière's example as performatively disrupting power relations places femininity at the site where power breaks down. The power relations in this story lie not just between the analyst and her patient but also between two analysts: the one (Jones) who makes the classification, and the other (Rivière) who clouds that classification. As the introduction to the essay makes clear, what is valuable to psychoanalysis about the work of Jones is his classification of female types: power here exists as the ability of the doctor to be able to look at the patient and to classify her based on both auditory (what she says) and visual (what she does) assessment. But a scientific discourse that looks to "femininity" for evidence regarding sexuality is eventually going to raise questions about that discourse's status as scientific. As a performance, femininity functions outside productive discourse. Rivière uses femininity in a way that challenges the authority of productive discourse, its ability to create sexual meaning based on feminine performance. Rivière's discourse is seductive in that it challenges and does not offer an alternative. Femininity defies the structure that claims to contain it through classification. Unlike 
Jones, Rivière does not set up another discourse of power (classification) to "clarify the knowledge that we [have] already."

After citing several more examples of women who perform "womanliness," women who are quoted as "having great ability," as "competent," "well-informed," and "clever," including one observation of the phenomenon occurring in homosexual men, Rivière concludes:

It is significant that [the lecturing] woman's mask, though transparent to other women, was successful with men, and served its purpose very well. Many men are attracted in this way, and gave her re-assurance by showing her favor. Closer examination showed that these men were of the type who themselves fear the ultra-womanly woman. They prefer a woman who herself has male attributes, for to them her claims are less. (311)

If Rivière's analysis can be understood as ironic, in the fact that she too is performing the masquerade, and if this article has an audience of not just psychoanalysts but also "all the women engaged in professional work today," then Rivière is making the transparency of the mask available to other women (304). It is not so much that professional women "naturally" see the mask as transparent; rather, the significance of the mask's purpose is asserted through a veil of universality (women see through it).

For Rivière, the man is attracted to the mask because the social dictates that define his masculine power require him to find the same reality in everything, the reality behind the mask, and the production of meaning. The power of masculinity is the power to construct discourse in a way that renders the world classifiable and knowable (what makes Ernest Jones such a key figure in psychoanalysis). "Many men" cannot deny the challenge to their masculinity. This type of man relinquishes his power to femininity in his attempt at classification. If this type of man can be understood to include the analyst, 
which I assume by Rivière's veiled "flirtation" in her introduction, then the flaw in his "scientific discourse" is exposed: the patient who enacts "womanliness" cannot provide evidence of her sexuality because "womanliness" does not produce meaning. The reason that Rivière asserts that men prefer women who espouse masculinity is that they find their discourse of productivity reflected back upon them as truth. Women who practice masculinity confirm the ideology of masculine power. This ideology asserts that the psychosexual world must be rendered visible, while womanliness functions to mask or to disrupt that power.

Rivière refuses to establish both category and hierarchy of thought. In anticipating her audience's desire for definition and specificity, Rivière writes,

The reader may now ask how I define womanliness or where I draw the line between genuine womanliness and the 'masquerade.' My suggestion is not however that there is any such difference: whether radical or superficial they are the same thing. The capacity for womanliness was there in this woman - and one might even say that it exists in the most completely homosexual woman - but owing to her conflicts it did not represent her main development, and was used far more as a device for avoiding anxiety than as a primary mode of sexual enjoyment (306).

Womanliness makes no distinction between reality and fantasy, the genuine and the fake, the conscious and the unconscious. Womanliness cannot be used to draw lines. It is a tool that blurs the lines between reality and performance, privileging neither. The capacity for womanliness does not derive from a woman's sexual nature because it is a "device" that can be "radical," used purposely with the aim of disrupting power, or "superficial," assumed with no such purpose in mind. In this way Rivière does not allow the concept of value (the assertion of sexual difference) into her discourse on womanliness. Womanliness, like Baudrillard's concept of seduction, is a tool that breaks down the 
productive and discursive "code," the political backslash upon which power relies. ${ }^{4}$

Contrary to Butler's argument that Rivière masks female homosexuality by asserting womanliness as an asexual position, womanliness is not (a)sexuality (67). Rather, Rivière blurs the heterosexual/homosexual divide by refusing to designate who can employ "womanliness" and to what end. Rivière does not mask female homosexuality in that sense; rather she breaks down the distinctions upon which the subordination of both women and homosexuals relies. In this way, seduction also provides a way for feminists to negotiate the hetero/homo divide.

In concluding her essay Rivière returns to her early assertion about the “womanly" woman who, according to Jones's classification, fulfilled all of the requirements for "complete feminine development" (304). In developing her argument, Rivière changes the apparent "given" into a question: "What is the essential nature of fully developed femininity?" (313). The question posed incorporates two words, “essential" and nature," that are conspicuously lacking from Rivière’s initial assertion that the womanly professional woman partially succumbed to classification. The suggestion here is strong, that analytic discourse posits, identifies, and names what is natural, and thus establishes a discourse of essentialism that is understood as natural. Rivière's answer is ironic and surprising because it does not indicate a truth about fully

\footnotetext{
${ }^{4}$ While Rivière makes no distinction between "real" womanliness and "fake" womanliness, Baudrillard does. According to his definition, seduction can be both authentic and simulated through a "dramatization of a refusal of seduction" (121). Baudrillard's simulated seduction resembles Rivière's definition of the womanliness used as "a device for avoiding anxiety." But setting up a hierarchy of thought for seduction and/or womanliness is completely antithetical to the attraction seduction proposes for feminist theory, the breakdown of hierarchy and value.
} 
developed femininity, nor does it suggest that the answer is yet to be found; rather her answer turns the question back to reflect the male psychoanalyst: "The concept of woman as a mask, behind which man suspects some hidden danger, throws a little light on the enigma" (313). That "man" who succumbs to womanliness, the one Rivière refers to throughout her essay, is clearly Ernest Jones, the great psychoanalyst who "throws great light on his material," who makes sense of things (303). What is even more compelling about Rivière's answer is the breakdown of effective communication in this instance. That is, Rivière does not explicitly name Jones but invokes him through the word "light." The wording is more poetically ambiguous than productive analytic prose. ${ }^{6}$ I do not mean to suggest that Rivière's essay is autobiographical, as some have argued, or that she is only addressing Jones. Rather, Rivière is addressing psychoanalysis as a productive discourse. Analytic power is disrupted at the site where knowledge cannot be ascertained. What Rivière describes is an almost compulsory psychoanalytic need to revisit femininity as the site, or sight, of some classifiable, qualitative, quantitative value-laden measurement. Because the temptation to classify is so strong within Western culture

\footnotetext{
${ }^{5}$ I understand Rivière's early assertion that Jones "throws great light upon his material" to mean that he makes sense of things, as in he "sheds light." However, in conjunction with the later morally ambiguous assertion of the man who "throws a little light on the enigma," the words "throwing light" could also suggest the imposition of meaning, forcing meaning rather than rendering it visible.

${ }^{6}$ In discussing the importance of poetic language to Baudrillard's theory of both seduction and symbolic exchange, Grace writes, "poetic language can be understood as a site of extermination of the relentless positivity of value, its structural predicate, the Law" (174). That is, poetic language is not a structural representation but a symbolic operation that de-materializes the sign and representation. Poetics shatters the structural Law, which Baudrillard defines as discourses of psychoanalysis, signification, desire, production, and value.
} 
(particularly in psychoanalysis), the possibility for the disruption of power is seemingly

endless. Rivière does not assert productive truth. She disrupts power through performing “womanliness" (or what Baudrillard terms seduction). Understanding Rivière's essay as a performance that simultaneously eulogizes, employs, and undermines the work of psychoanalysis emphasizes not only Rivière's continued relevance, but also that rereading her through Jean Baudrillard's theory of seduction shows what we've missed, that feminism was and is still in motion, still escaping the finalities that even feminists fall for.

\section{Equality: A Guinea for Your Thoughts}

Seduction has no power on its own, only the power of annulling the power of production. But it always annuls the latter. Has there, moreover, ever been a phallic power? This entire history of patriarchal domination, of phallocracy, the immemorial male privilege, is perhaps only a story. Beginning with the exchange of women in primitive societies, stupidly interpreted as the first stage of women-as-object. All that we have been asked to believe - the universal discourse on the inequality of the sexes, the theme song of an egalitarian and revolutionary modernity - is perhaps one giant misunderstanding.

\section{-- Jean Baudrillard Seduction}

Most feminists who proclaim to $b e$ feminists would argue the need for equality as the central motivation behind their work, so much so that the term "equality" has been separated from its traditional use, as the enlightenment slogan of the French and American revolutions, though is now used primarily and similarly as a term to describe liberation movements. Early feminists, such as Mary Wollstonecraft, used the rhetoric from these revolutions as a model for imagining women's equal rights but did not challenge the value of perpetuating masculine ideologies of equality. In Undoing Gender 
(2004) Judith Butler argues too, "I think it is fair to say that feminists everywhere seek a more substantial equality for women, and that they seek a more just arrangement of social and political institutions" (174). Though Butler eventually critiques what Wollstonecraft takes at face value, few feminists theorize the double bind of the term "equality," as it relates to feminism, more thoroughly than has Virginia Woolf. What concerns Woolf is that the term "equality" contains hidden power relations. In Three Guineas (1938) Woolf questions the value and ideology of social and political institutions such as education and the professions in order to explore the inherent discrimination built into the fabric of such institutions. She concludes that hidden ideologies serve to strengthen a social system that reinforces the necessity for war. According to Woolf, women who join these institutions on a par with or equal to men will necessarily perpetuate discrimination and violence. ${ }^{7}$ Where men set the terms by which equality becomes desirable, women perpetuate these values rather than challenging them. Recognizing equality as a value-laden term that masks power relations may even make the concept of equality undesirable.

In Virginia Woolf and Postmodernism (1991), Pamela Caughie underscores the importance of performative writing in Woolf's Three Guineas to argue that: “Woolf's rhetoric... has allowed her not just to sound uncommitted but to remain uncommitted to

\footnotetext{
${ }^{7}$ Virginia Woolf's work, like the work of Helen Gurly Brown, discussed in chapter five, continues to suffer at the hands of productive reading practices that perpetuate reductive and limiting views. In a recent article "Marketing Virginia Woolf: Women, War, and Public Relations in Three Guineas" (2009), Alice Staveley argues that Three Guineas posed such an affront to the social equality of professional women that it required a defensive marketing strategy employed by Norah Nicholls, and specifically designed to assuage the negative reaction from women's organizational groups in the late 1930s. According to Staveley, Woolf's sins against professional women include her figuration of professional women as "potential sell outs," and her "reinforce[ment of] longstanding misogynist stereotypes that associated the professional woman with the prostitute" (305).
} 
any one position, thereby enabling her to investigate the complexities of tyranny" (116).

Theresa Winterhalter expands upon Caughie's work to argue that, "by subverting expository tradition, [Woolf] hopes to perform a significant act of engaged rebellion against linguistic practices that align with totalitarianism" (238). Readings like Caughie's and Winterhalter's that focus on the performative effects of Woolf's writing in Three Guineas - the way it wastes time while continually reminding us we're pressed for time, for example - still suggest this kind of writing is done in the name of some other set of values. I would argue, instead, that Woolf's writing is even more radical in that it is seductive, ritual, merely throwing a cog in the wheel. While performative writing is seductive, in that it breaks down linear, unitary, and rational arguments, seduction is not the same as performativity. Seduction is less about finding an alternative than about turning the opponent from his game, his truth. Seduction, according to Baudrillard, involves a realization that coded structures of productive value exist behind the meaning of words and in turn behind society in ways that mask power relations, hierarchy, and domination. Seduction involves a move to empty signs of their referents in an effort to disrupt controlling logic through the challenge and the game. Woolf's subversion of totalitarian social structures in Three Guineas goes beyond Winterhalter's argument that Woolf is primarily "subverting expository tradition" through performative writing. ${ }^{8}$

\footnotetext{
${ }^{8}$ A seductive reading parts ways with Winterhalter, when she argues that "Reading Three Guineas with an ear to the rhetorical performances of Woolf's speakers reveals her outlines for the methods or linguistic practices, not only the theories, that must serve to prevent war" (239). It seems facile and perhaps a-historical to argue that expository writing is responsible for war and that performative writing is the answer Woolf suggests - particularly as Woolf is persistently resistant to answering the question of how to prevent war. To espouse such an argument would be both an argument for a universal
} 
Seduction requires not just a theory of writing but a theory of reading as well. A seductive reading would remain skeptical of the view that Woolf "enact[s] a moral position to which she is deeply committed" (Winterhalter 233), or that she "speaks in the name of human decency," as both positions impose liberal humanist values upon Woolf's text that her use of ironic, biting language challenges. (239). If Woolf's writing is seductive, as such, it cannot be moral nor can it speak for human decency because it is first and foremost artificial and anti-representational. If anything, seduction is cruel because it refuses to play by the productive morality of truth and value. This is why woman in the profession are denied value in Woolf's text. No man or woman who espouses productive morality escapes Woolf's text unscathed.

Three Guineas is composed of three parodic, ironic, and overlapping letters in response to written requests for donations to three philanthropic societies which are working on behalf of women's education, women in the professions, and national efforts to prevent war. In responding to the letter regarding the effort to prevent war, Woolf composes a parodical productive response revealing the ways in which societies structured in and through productive discourse function to sow confusion, recycle old ideas, and thwart action. Woolf writes,

It is distressing, baffling, confusing, but the fact must be faced. There is no certainty in heaven above or on earth below. Indeed, the more we read, the more speeches we listen to, the more opinions we consult, the greater the confusion becomes and the less possible it seems, since we cannot understand the impulses, the motives, or the morality which lead you to go to war, to make any suggestion that will help you prevent war. (13)

position, and would marginalize the importance of reading (not just speaking) practices, which also figure heavily into Woolf's work especially in relation to the photographic image which bares no words but simultaneously begs reaction. 
Woolf's argument simultaneously mirrors the productive stance and exposes its inherent weakness. Her argument seems to espouse the view that war is inevitable, but her writing also highlights the fact that war is inevitable within the present system of communication. According to Woolf, knowledge about war effectively strengthens war because the perpetuation of communication about war denies any outside position from which to stand and fight it. Language about war structures and limits our reaction to it.

The media, its images, and reports function to confuse Woolf (as they are meant to do). ${ }^{9}$ The fact that the war is present everywhere in discourse makes it hard to imagine a way out of it. Even those positions taken contrary to the war effort still recognize war as something stable out there in the world that may be preventable, but that is now a reality. From this perspective, Woolf cannot see anyway outside the structure: war is a present and pervasive reality. Woolf has consulted many knowledgeable sources but the answer to the question of war is not to be found in any discourse about war. Production and communication thus structure society by making everything known and visible from all angles. The production of information deters Woolf from being able to think outside the system that has created it. Woolf's assertion of her own weakness in the matter of war prevention, her "distress," her "bafflement," and her "confusion," are presented as a result of the inherent weakness of a system that, regardless of its claim to truth, is unable to either inform or communicate certainty.

\footnotetext{
${ }^{9}$ For more on Virginia Woolf's use of the photographic image to destabilize fact and meaning, see Helen Wussow's "Virginia Woolf and the Problematic nature of the photographic image."
} 
Woolf espouses a similar model of productive parody to discuss women's equal participation in the social institutions of the professions and of education whereby she concludes that anyone who speaks from inside the productive system will necessarily strengthen and propagate the injustice of that system. Addressing women who enter the professions under the current structure for work and employment, Woolf writes,

You will have to wear certain uniforms and profess certain loyalties. If you succeed in your profession, the words "for God and Empire" will very likely be written like the address of a dog collar around your neck. And if words have meaning, which perhaps they should have meaning, you will have to accept that meaning and do what you can to enforce it. In short, you will have to lead the same lives and profess the same loyalties that professional men have professed for many centuries. (81)

Women, in joining the professions, have not, according to Woolf, gained "freedom" or "liberation." They are newly bound to profess loyalty to their employer, and to espouse the views of the employer in order to be successful. They are not free to wear what they want, or to act in any way that is inconsistent with the stated goals and aims of the company. The idea - going back at least to Charlotte Perkins Gilman, if not further - that men have historically been "freer" than women because of their ability to produce is here exposed as a ruse, a social myth that continues to strengthen as women gain access to the professions. Because the professions, according to Woolf, are so heavily invested in the desire for economic capital, it follows that competition, hierarchy, and nationalism are inevitable.

Woolf's discussion of the meaning of words is particularly important to her argument and continues to have political relevance to feminism. She is not fully convinced that words should have meaning, or should necessitate meaning. Woolf asserts 
that definitions of words often kill entire radical movements: “The word 'feminist' ... according to the dictionary, means 'one who champions the rights of women.' Since the only right, the right to earn a living, has been won, the word no longer has a meaning" (117). If we, as feminists, accept that words have meaning, we will "have to accept that meaning and do what [we] can to enforce it." For Woolf, defining words is complicit in the productive model as well as in the rational search for meaning. In using words, women must be aware that they are bound to an existing system of meaning and that their words will be used to propagate that system, a system that existed before they arrived in the public workplace, an oppressive system, and one which woman will now be expected to uphold. Women, in gaining access to the professions, are subject to a host of meanings that are embedded within the concept of "the profession." These include but are not limited to the desire to protect property, to decry foreign invasion of that property, and to make men want to go to war to protect their assets. In order to be successful, to have value for society, women in the professions must in turn exert authority and power over others.

Like women who enter the professions, women in the universities will similarly be expected to protect a system of value that is based on gain, fear of loss, and subsequent subjugation and oppression of others. Indeed, the concept of value is an ideology of particular concern to Woolf in Three Guineas. In her section addressed to the “treasurer asking for money with which to rebuild a woman's college," Woolf notes that the value of education in England is a many-edged sword (27). She considers donating to the women's university with the stipulation that the money be used to help women learn 
ways to prevent war. What gives her pause about the plausibility of such a request is always a question of value. She argues that, insofar as education takes a raw human being and turns him/her into a finished product, "there can be no doubt of the value of an education" (28). Woolf's "there is no doubt" inevitably raises doubt. Woolf discusses the ways biographical writing perpetuates the ideology that "the value of education is among the greatest of all human values" (28).

Biography reinforces the value of human potential. It functions to justify the massive amount of money that goes into the education system. Biography has often celebrated the historical value of women to the extent that they sacrifice their own education in an effort to educate their sons and brothers. The concept of value is what structures society in ways that privilege some of its members and keeps others in their place. Woolf argues, "[Biographical] facts, as facts so often do, prove double faced; for though they establish the value of education, they also prove that education is by no means a positive value; it is not good in all circumstances, and good for all people" (3031). Value is an ideology that structures society in ways that prevent its subversion. That is, we cannot talk about the value of women's education except in relation to the value of men's education. Insofar as men's education is established as "the greatest of all human values," a woman's education must mirror those values in order to have cultural currency, in order that both educations should possess equal value. Thus, it is impossible to suggest that women's universities should be structured according to different values (e.g. pacifist ones), when the value of education is structured according to the legitimacy of productive discourses that do "not teach people to hate force but to use it" (35). Woolf 
exposes the ways in which women who come to the university and the professions under the myth of liberation and equality end up supporting efforts to strengthen British nationalism, which perpetuates war. The structure of education, the professions, and war heavily reinforce one another through systems of value and meaning making. In this way, Woolf undermines the value of arguing for the value of education. Education per se has no value; it is what we make of it. It's an empty signifier.

Woolf realizes that a system of production cannot be changed from within. She does not argue for female equality within the current structure, nor does she believe that the system will change because a greater number of women are invested in its values. Woolf asserts that women "are between the devil and the deep sea" (92). There is no solution to the problem of inequality either through opposition to the system (in which women have no power) or through entering into that system on its own terms. But Woolf does acknowledge that there is a way to enter the professions "and escape the risks that make them undesirable" (92). This process involves a systematic challenge to the factual knowledge and meaning associated with the value of professions. If knowledge is somehow ascertained through work, "give the knowledge acquired professionally to those who need it for nothing" (92). In a reversal of rational logic, Woolf suggests that acquiring knowledge within a profession has no monetary value. Similarly, accepting awards and merits supports meaning associated with a given profession and should be rejected. Woolf writes, "you must refuse all methods of advertising merit, and hold that ridicule, obscurity, and censure are preferable, for psychological reasons, to fame and praise" (93). "Fame" and "praise" bestowed by the current professional system will only 
serve to prove that "you" support the meaning and value that are perpetuated by the profession and that you are thus bound to profess loyalty to that profession. Awards, merits, and even donations are put in place to structure conformity to masculine values and production.

Woolf warns her young female professional to be wary of the "mulberry-tree" that poses a continuous threat to the necessary challenge to meaning and knowledge. The mulberry-tree has become a figure often cited by feminists as a "metaphor for our devotion to property" (Caughie 116). But I'm leery of stopping here, to assume that the mulberry-tree means anything when Woolf has expressed a call to challenge the authoritative meaning and value of words. In her suggestion that productive meaning should be avoided, Woolf performs the action she calls for by divesting this "mulberrytree" of meaning and value. I would argue that fixing the meaning of the mulberry-tree as a metaphor for property, or any other term, is antithetical to the function of the mulberrytree as a seductive, artificial, and mythical device used to empty irreversible ideologies of their meaning. Likening the "devotion to property" to an endless, frivolous children's game, explicitly serves to divest property of meaning, value, unity, and coherence.

Analysis of the actual game "mulberry bush," to which Woolf alludes in her mention of the "mulberry tree," shows that the mulberry tree is not limited to representing devotion to property but is in fact a bigger and more far-reaching representation, extending to all productive systems, including that of gender performance and labor, and thus to nothing in particular. To illustrate this point I turn to a work entitled Popular Rhymes in Nursery Tales: a Sequel to the Nursery Rhymes in England 
(1849), by James Orchard Halliwell-Phillips. In his discussion of popular nursery rhymes in England, Phillips provides two analyses of the performance and language involved in the popular nursery rhymes "Mulberry Bush" and "Bramble Bush." Both games are described as "a ring dance, imitation play" that is "often imaginative but sometimes represented by a child in the middle of the ring. All join hands and dance round in a circle singing" (126). The "Bramble Bush" nursery rhyme is primarily a game which employs the joyful simulation of various kinds of labor: washing clothes, drying clothes, ironing them, and putting them away, duties that can be performed "ad infinitum." The bramble bush game has a feminine element whereby the children are characterized as behaving "like good merry washing women [who] are not exhausted by their labors" (127). That is, the Bramble Bush song enacts the positive value of a hard day's labor, not as taxing, but as fun, as a practice of winsome femininity. Phillips describes this game as "a matter of domestic economy aimed at by the author." Thus, the bramble game is rife with ideologies that support a gendered, coded, and classed system: women's work is in the home; domesticity for women is natural, fun, endless, and inevitable (as the circle maintains); and domestic workers must really enjoy their jobs.

Although both games employ the same melody and similar actions, Woolf chose to reference the mulberry over the bramble, not without significance. In contrast to the feminine bramble game, the mulberry game is much more difficult to define and code structurally. Phillips writes, "it is not so easy to give a similar expression to the game of the mulberry-bush, conducted in the same manner" (127). The mulberry-bush game, according to Phillips, cannot be analyzed for meaning either in terms of gender, class, 
domestic life, or economy. The verses of the mulberry-bush differ in performative action to include not just domestic duties like washing clothes, but also the making and mending of shoes and identity performance, as in the verses "this is the way the ladies walk" and "this is the way the gentlemen walk." The mulberry-bush is a larger and more diverse game that involves a wider range of seemingly unrelated tasks that cannot be read as uniformly sex specific.

Furthermore, Phillips reads the verses of the bramble-bush game as contributing to a rational goal, because the last line "on a cold and frosty morning" implies functional warmth through the performance of exhilarating action. In contrast, the mulberry game ends "on a sunshiney morning" (127). The game is not only rendered meaningless, but the reasons for playing it also escape logic. Phillip describes the fun of the mulberry game as limited and limiting, or threatening to children's health: "this game, however, implies too much exercise to render it so appropriate to the season as the other" (128). In short, the mulberry game defies meaning. It seems to have no value (as in keeping warm), or intent (making domestic chores palatable). The adjectives used to describe the mulberry children's game can then be re-inscribed upon ideologies of sex, labor, knowledge and property, which are all performed within the game through repetition and mimicry. Woolf's ironic assertion that in singing "Here we go round the mulberry tree, the mulberry tree, the mulberry tree," and in adding the verse "of property, of property, of property," she would "fill in the rhyme without doing violence to the facts," exposes a linguistic violence that she would like not to be made obvious - or instantiated as a truth claim (76). Woolf's mention of the "mulberry tree" is invoked not to subvert property 
per se, but rather to erase the value of entire systems of production. The function of the "mulberry tree" is more important than its meaning because the symbol of the "mulberry tree," when used in relation to a children's game, empties the productive system of both meaning and value. Coded systems are merely games that rely on the mechanical movements of the players to sustain themselves. I would argue, then, that the mulberry tree, like Baudrillard's fairy tale, functions in the text as an absurdity, a nonsensical distraction, a sleight of hand rendering the entire system of production valueless, powerless, and exposing its weakness as a structure reliant on the performance of bodies that constantly threaten to break away.

And yet the threat of the circle still looms, causing Woolf to issue another warning, "But directly that the mulberry tree begins to make you circle, break off. Pelt the tree with laughter" $(92) .{ }^{10}$ Because we have by now acknowledged the non-sense and the meaninglessness of the mulberry tree, and because the system of production has been emptied of its context and value, to break off appears relatively easy. But it is, apparently, not enough to empty signs of their referents. The continued powerlessness of the productive system is reliant upon a continued and ruling absurdity of signs. Although the laughter proposed by Woolf could be read as another "metaphor," I recognize laughter as a non-sense term similar to that of the mulberry tree, another sign without referent,

\footnotetext{
${ }^{10}$ Baudrillard argues that seduction as a single movement is "a stroke of wit or a flash of inspiration: a 'spiritual' economy. With the same duel complicity as a stroke of wit, where everything is exchanged allusively, without being spelled out, the equivalent of the allusive, ceremonial exchange of a secret" (112). Woolf's stroke of wit, her laughter in this passage levels all meaning and value as allusive rather than constitutive. Laughter then levels the playing field linguistically as the meaning of laughter is as allusive as the reasons for playing a game.
} 
instantiated as insurance that no productive system of power or truth will replace the one that has been linguistically devalued. Thus laughter uttered into the void of the mulberry tree similarly devoid of meaning insures that "the mulberry tree" remains without meaning. The laughter is empty and carries no truth to replace what is destroyed. Laughter functions in the text to create a radical "break" from the meaningless valueless circle of production without arguing for another value.

Woolf, like Baudrillard, recognizes an outside to the contemporary productive power structures, "the facts of history, of law, of biography" (122). She refers to this position as "the Outsiders Society." Woolf writes:

They would refuse in the event of war to make munitions or nurse the wounded ... the next duty to which they would pledge themselves ... is briefly, not to incite their brothers to fight or to dissuade them, but to maintain as attitude of indifference. (122-123)

To work on the sidelines of war is to perpetuate war, even when working to nurse the sick and injured. Women are thus figured in Woolf's estimation as not victimized by but complicit with the production of the current power system. To gain employment that gives ammunition to the war strengthens the system of war. Women who fight men on the subject of war assume the kind of adversarial stance that leads people to declare war in the first place. The outsider society, in contrast, remains indifferent. The concept of indifference in this passage can be read as a third position from which to critique the structure of identity/difference. To "incite the brother to fight" is a position that would claim "identity" or "identification" with masculine values of war. On the other hand, "to dissuade them" would be a claim to "difference," or different and oppositional values. Indifference is a position, which challenges the structural law that provides for Woolf 
only two positions: war is good and war is bad. Indifference is presented as a break in effective communication in a radical challenge to meaning. This does not mean, contrary to the belief of feminists who critique postmodern theory as apolitical, that Woolf did not act. She donated all three of her guineas. It just means that, as feminists, we should resist naïve positions or claims to victimization that reinforce productive systems. Money, which can be given freely or in exchange for a service, is also structured in and through discourses of production and value. Woolf is most certainly aware of the fact that her money will be used to advance the code of economic value. Her writing in Three Guineas is both an acknowledgement of and an attempt to reverse the effect of that fact.

\section{Subverting Identity: Or Feminism's Fictional Identity Crisis}

She constantly avoids all relations in which, at some given moment, the question of truth will be posed. She undoes them effortlessly, and not by denying or destroying them, but by making them shimmer. Here lies her secret: in the flickering of a presence. She is never where one expects her, and never where one wants her.

-- Jean Baudrillard

Seduction

In the essay "Difference: 'A Special Third World Women Issue'” Trinh T. Minh-ha expresses reservations about using the term identity (and its imaginary friend, difference), even when feminists try to re-imagine or re-define the term as plural, fluid, multiple:

"[Feminism] seems quite content with reforms that, at best, contribute to the improvement and/or enlargement of the identity enclosure but do not, in any way, attempt to remove its fence" (16). Trinh's concern is that, as a Western concept, "identity" is structured by Western laws of what constitutes identity (or identities). That is, in the West we can only come to know identities as they relate to our definition of identity; thus any 
attempt to understand non-Western identities will necessarily be informed by Western thought. Consequently, feminists who argue for identity (in any capacity) perpetuate the politics of a white male power structure. Thus, the project of many contemporary feminists, like Judith Butler, has been to imagine action and agency without invoking the ideology of identity. Feminists must be concerned with action over identification.

In her chapter entitled, "The Fictions of Identity, Power, and Desire" Victoria Grace begins by questioning the effectiveness of Judith Butler's concept of performativity in the subsection: "Butler: Subverting Identity?" The positioning of the question mark as part and parcel of her title suggests that Grace has doubts about Butler's ability to radically alter thinking in terms of identity. Indeed, Grace's arguments against Butler are legion. In Grace's reading, Butler's theory of performativity is productive because her theory tends toward the universal and is not situated historically, not grounded in "culture" or "place." Grace also fears that Butler's articulation that there is no "true gender identity" is an assertion of "truth" that runs the risk of being instantiated rather than critiqued. According to Grace, the idea that there is no true gender identity is a simulation of identity politics because it has substituted one truth, "there is no," for another truth, "there is," without radically critiquing the "newer" position. Finally, and most critically, Grace dismisses Butler's position that there is no outside to constructed identities; she perpetuates Foucauldian ideology: there is no position outside power. Grace quotes the following passage from Gender Trouble: Feminism and the Subversion of Identity (1990) to prove her point:

The critical task of feminism is not to establish a point of view outside of constructed identities; that conceit is the construction of an 
epistemological model that would disavow its own cultural location and, hence, promote itself as a global subject, a position that deploys precisely the imperialist strategies that feminism ought to criticize. (187)

Grace uses this quotation to argue against Butler's conceived course for feminism on the grounds that Baudrillard's concept of "symbolic exchange" resides outside the structure for identity. As Grace argues, symbolic exchange is "excluded by the binary logic of constructed identities: identity/difference" (63).

As I explained in my introduction, symbolic exchange does not distinguish between the subject and object because the object given in symbolic exchange cannot be separated from the act of the exchange itself. Baudrillard argues that in "primitive" societies, the object(s) exchanged between individuals or clans was less important than the bond that was established. The object, given as a gift outside of the political economy - in that it has no value on its own - becomes a symbol of the relationship rather than constituting the relationship according to the laws of the political backslash, or subject/object divide. Symbolic exchange is not a matter of giving some thing but a symbolic act of divesting oneself. In refusing to allow the object any importance, symbolic exchange avoids both hierarchy and power relations. Thus, Grace heartily advocates for creating a space outside of constructed identities (subjects or objects). For Grace, the concept of "symbolic exchange" challenges Butler's position that identity subversion is only possible from within the terms of paternal law. Within this formulation, power is inevitable. Power constantly produces and it produces "subjects" who are always subject to the law (of identity) with only brief moments of subversion. 
However, I read Butler's position differently than Grace. When Butler writes that the critical task of feminism is not to "establish a point of view outside of constructed identities," she is not asserting that there is no outside to "identity." Butler reinforces what she means by the "point of view outside" in her next phrase, "the construction of an epistemological model." It is this epistemological model that should be avoided. As a system for knowledge the "epistemological model" relies heavily on setting up categories for distinction and is heavily immersed in ideologies of value and hierarchy. Butler writes, "the epistemological paradigm that presumes the priority of the doer over the deed establishes a globalizing subject who disavows its own locality as well as the condition for local intervention" (188). What is important for Butler is a theory of action and agency without the perpetuation of identity categories. Thus, when Butler asserts that feminism should be critical of establishing an "outside," she is referring to the perpetuation of epistemological identity categories. To rephrase Butler: the critical task of feminism is not to establish an outside identity, or outside identities, that reconstitute the "global subject." Alternate fixed identities and alternate fixed systems for knowledge about identity should be resisted. The fact that there can be a series of acts that repeatedly fail to constitute identity is quite subversive. Within the traditional notion of what constitutes political power (particularly as it is recognized by Marxist ideology) a "global subject" with consciousness must be established before political agency can occur. Performativity is agency without (or with misfiring) identification, feminism outside of productive ideology. 
In Bodies that Matter: On the Discursive Limits of Sex (1993), Butler makes clear

that she does not accept the ideology that there is no outside to identity and power. In a fictive account of the way in which subjects come into being through normalized sexual practices Butler writes:

This exclusionary matrix by which subjects are formed thus requires the production of a domain of abject beings, those who are not yet 'subjects,' but who form the constitutive outside to the domain of the subject. The abject designates here precisely those "unlivable" and "uninhabitable" zones of social life which are nevertheless densely populated by those who do not enjoy the status of the subject, but whose living under the sign of the unlivable is required to circumscribe the domain of the subject. (3)

The concept of the "subject," as Butler reveals, is truly a position of privilege. Under this rubric, it would seem as if allowing everyone access to this privileged "subject" position would be all that is required to endow all subjects everywhere with the conditions to make their lives livable and acceptable. But, unfortunately, Butler argues, this privileged position exists only in direct relation to the abject position. The only way that a subject can become a subject is through positive identification with other subjects and a complete rejection of the abject position. In Butler's discourse, identification with the subject position is identification with normative "sex." I would add that normative "sex" is not the only position that provides entry into the privileged realm of subjectivity. Productive labor and gender difference are also values that allow entry into the "livable" "habitable" world of subjectivity. These productive discourses rely not only on the negation and the disavowal of the domain of abjection, but also on the reiteration or perpetuation of these norms. For Butler, it is the disavowed abjection that threatens to expose the "self grounding presumptions" of the sexed subject. It is the abject threat that, for Butler, 
becomes the critical resource for concepts of symbolic legitimacy and intelligibility. Because these livable, habitable subject positions (bodies) are reliant upon constant reiteration (materialization), subject positions are unstable, and norms are constantly in danger of material noncompliance. Within the discourse proposed by Butler, disidentification is the crucial term by which we contest the privilege of the subject. For Butler, these abject and excluded positions haunt the boundaries of the subject position as the constant possibility for the disruption and re-articulation of those boundaries. Not everything, according to Butler, is discursively constructed.

What can be particularly frustrating about Butler (but also what helps to prove my point about her theory as seductive) is the fact that her theory of the abject is so beyond the realm of representation that she does not even provide her reader with examples of what she means by her terminology. While Baudrillard provides examples of what constitutes "symbolic exchange" and "seduction," Butler will not. When Butler writes that the "exclusionary matrix by which subjects are formed thus requires the production of a domain of abject beings," she is acknowledging that to identify and to define what makes an abject being is a productive move, and one she is obviously not going to support. The "abject position" is a discursively produced fiction at once invoked by Butler and refused definition in a strategic move to challenge the notion of the subject and of the possibility for positive identification. The "abject" is simply that which has yet to be made real. It is empty and without content precisely because she does not want the abject to become normative, a new position. Thus abject bodies present a disruptive challenge to positive or even provisional identity. 
For Butler, one of her biggest mistakes in Gender Trouble was that performativity became recognized through the drag performance and thus lost the possibility for a reversal of logic: "I brought [the construal of gender-as-drag] upon myself by citing drag as an example of performativity, a move that was taken then, by some, to be exemplary of performativity. If drag is performative, that does not mean that all performativity is to be understood as drag" (231). For Butler, gender is to an extent an assignment, which is never quite carried out according to expectation. The repetitive failure to deliver the "ideal" that $\mathrm{s} / \mathrm{he}$ is expected to enact (the performative) constitutes the space for a radical refusal of binary logic. But the performative as a concept does not always have radical potential because its aim is established as the need to instantiate normative sexual identity. To understand the performative as a metaphor for drag closes off the possibility for the subversion of identity to the extent that the performative is now invested with positive meaning, value, and identification.

Grace's criticism of Butler's language "there is" or "there is no," as espousing the very epistemological discourse she critiques, is a common complaint due to the feminist move to avoid intellectual surety and essentialism. This very complaint is at the heart of a 1998 interview in Signs where Irene Costera Meijer and Baukje Prins ask Butler to defend her assertion in Bodies that Matter, "there is no doer behind the deed," an apparently irreversible reversal of the traditional subject position that instantiates being as a necessary precursor to doing. If Butler's aim is to protect feminism from essentialism, then she is most assuredly working against herself by arguing this essentialist claim. In this particular interview Butler defends her use of grammar, "there is" and "there is no," 
by arguing that "there is no" is not an assertion of truth, but rather a "counterimaginary to the dominant metaphysics" (279). Although Butler recognizes an outside to the privileged position of subjectivity, she chooses to see her work as within the productive system. For Butler, the key to undoing discourse about ontology is through overloading the circuits of information on ontology. Butler's position, by her admission, is one of opposition to productive discourse through the repetitive misuse of that discourse, since it is dissonance that causes change. In this way Butler is not unlike Baudrillard, in that he similarly recognizes a need for dissonance and contradiction in theory.

Although dissonance is an important concept for seduction, I have questions about Butler's ability to know exactly where she stands (or indeed her ability to tell others where she stands). How can Butler create havoc from inside the productive system when she nowhere espouses its views or asserts its truth? According to her own imaginary account of subject (inside) and abject (outside) positioning, Butler would be required, by locating herself inside, to perpetuate identification with norms while disavowing the abject position. She does, to an extent, disavow the abject position, in referring to it as "uninhabitable" and "unlivable," but she also protects the abject position both by using quotation marks, and by refusing to fill that position with an example (the way she did with performativity by linking it to drag). Even wanting to take Butler at her word, I cannot read her as engaging productive discourse from inside its structure: she admits that her discourse is fictive and production can only be asserted as reality. Butler's work is, regardless of where she sees herself, also in the abject position, the excluded position that haunts the boundaries of the subject position as the constant possibility for the 
disruption and re-articulation of those boundaries. Butler is not just jamming information with overload; she has also emptied out a space of non-identification in order to haunt the boundaries of subjectivity, ontology, identity, and sexuality (one might also add philosophy).

In order to bring out Butler's seductive side, I would like to discuss her argument about the nature of philosophy in Undoing Gender (2004), specifically the chapter, "Can the Other of Philosophy Speak?" The fact that there can be an "Other" of philosophy assumes that philosophy is the practice of the "philosopher," an identity category that carefully guards its borders in order to function as an academic field of analytic thought. One can identify as a philosopher only to the extent that non-philosophers exist: not all academics are philosophers. Although Butler opens the chapter by arguing that she has been trained in the history of philosophy, she also expresses doubt that her own writing “conforms to [its] standards." Butler asserts, "I do not live or write or work in the institution of philosophy" (232). Thus, to an extent, Butler is the "Other" to whom she is referring. She expresses anxiety about the fact that, as someone who does not identify as a philosopher, she nevertheless participates in philosophic discourse. Butler is both outside and inside the identification category. It is from this position that her engagement with philosophy "trouble[s] those who work within that institution" (232). Philosophers are productive to the extent that they make "value" judgments about what does and what does not count as legitimate philosophical knowledge. People who identify as philosophers, who create the rules about what is and what is not philosophy, have informed Butler on more than one occasion that she is not a legitimate philosopher. 
Butler's ironic reply: "It is surely impressive to be in such a situation and to be able to know with clarity what counts and what does not" (233). In short, Butler is not impressed by the rebuke. Reading philosophy, and being trained in philosophy, still does not qualify Butler as a philosopher. She is thus outside the identification category - the work that she does is also outside that category. Butler would like to make the borders of philosophy fluid, to see herself working within the discourse of philosophy in ways that jam its "clarity" with information, but she cannot because her discourse does not "count." Butler is, in Baudrillard's phrase, an "unmarked term" because she cannot support the "clarity" of philosophical discourse (an irony certainly given the many arguments that assert Butler's writing is "unclear").

I would like to propose, then, two readings of Butler's writing on philosophy: one in which she participates, inside the discourse of philosophy, in an attempt to abuse its discourse and contest its exclusive power, and another in which her position can be seen as outside the position of philosophy, not opposing it but seducing it. Although Butler's aim is not necessarily to be seen as an "equal" within the discourse of philosophy, nor does she care to assert herself as a philosopher, the target of her critique is aimed at the political backslash of philosophy (subject/abject) that makes her an unmarked term. But can one break the "code" by setting up an opposition to that code?

Butler follows her introduction to this chapter with a story about being interviewed as a child. The question asked of Butler is a standard question posed to any twelve year old: what do you want to be when you grow up? Butler answered that she wanted to be "a philosopher or a clown" (234). Butler reads her early indecision as being 
a question of "value." She had (and still has) "doubt about the value of a philosophical career" (234). And for Butler, the presence of "doubt" should deter any student from pursuing any scholarly career unless, Butler proposes, we can discern some "value" in "not being sure about the value of becoming a philosopher" (234). More specifically, "resistance" itself can counter the "current market values of philosophy" (234).

I have doubts about this position because, regardless of Butler's decision to pursue or not to pursue philosophy, the question is always a question of "value." One cannot talk about either "conforming to" or "opposing" philosophy except in terms of "value" because philosophy is a productive discourse based on exclusion and hierarchy. Philosophy currently excludes Butler from identifying as a philosopher because her discourse does not conform to the "value" of philosophical discourse: her writing does not count. It has no philosophical value. In recognizing the "value" of countering the "market values of philosophy," Butler perpetuates the discourse of "value," the same discourse that is used to exclude her. Butler cannot change the hierarchy of philosophical value by insisting upon an opposing "value." To that end, I can see Butler as inside the system. If she is inside, she is perpetuating exclusionary discourse based on value and not questioning its ability to exclude based on value. All attempts at subversion are forestalled.

A seductive reading of Butler would focus not on what Butler says, the meaning and value that she perpetuates, but instead on what she does not say, and what she is doing in her writing. As such, we would have to ask the following question: to what extent does Butler's discourse refuse to conform to the standard of philosophical value? 
The answer lies in her other possible career choice: the clown. Butler's mention of her desire to be the "clown" is brief, and the word "clown" is left hanging, an empty sign dangling in mid-air. Butler articulates her doubts about the value of being a philosopher but does not talk about the value of being a clown, nor does she express doubts about being a clown. Butler only mentions that her decision "depended on whether [she] found the world worth philosophizing about, and what the price of seriousness might be," later asserting, "I never quite overcame that doubt" (234). The question of (non)seriousness, then, is evidently a part of the equation in the story Butler presents. To what extent does the question of being a "clown" figure into her discourse on philosophy? Butler's early (and perhaps persistent) wavering between being a clown and being a philosopher was always dependent on a philosophical question of value. Thus, being a clown was always foreclosed by philosophical doubt and by nature of the questions Butler asks. Doubt is thus exposed as an inevitable effect of philosophy. If philosophical decisions are based on worth and value, then "being" a clown, which has no value in philosophical discourse, cannot be either a decision or a real question. The clown in Butler's discourse remains value free, it carries no meaning and no doubt. To what degree, then, was Butler's choice not to be a philosopher an acceptance of the outsider position that does not impose "worth," "value," and "doubt" upon others - that is, a choice to be a clown? Or was this choice not to be a philosopher a decision to ask other kinds of non-philosophical questions? And to what extent is Butler holding philosophy accountable for being unable to function except as an exclusive discourse of market value? 
A seductive reading sees Butler as challenging the philosopher's ability to do anything other than perpetuate itself repeatedly, exposing its weakness by using a position that philosophy recognizes as weakness - that of the clown, the non-serious, the position without value. ${ }^{11}$ The outside position thus challenges philosophy's power to function outside its very limited and limiting view, to understand anything in the world that does not reflect its sense of value. Contrary to Butler's belief, the challenge to philosophy does not come about from the insider position - the student who realizes that resistance to philosophy is another form of value - but rather from the outside position, the seducing clown who exists as silliness that exposes the weakness of philosophical discourse, of philosophical identity. The answer to Butler's initial question, "Can the Other of Philosophy Speak," is quite complicated. If we look at philosophy's other as represented by the clown that cannot be realized according to philosophical questions, then no, the other cannot speak. The good news is that neither can philosophy speak for the outsider/clown because philosophy would not even know what kinds of questions to ask. Butler may not have chosen the path of philosophy (difficult when the concept of her "value" so depends on the choice), but she could make a successful clown! It's funny to think that Butler might have been a clown. But it's even funnier that those who dismiss her as a clown (not a real philosopher) have been seduced by her.

\footnotetext{
${ }^{11}$ Baudrillard states that although the ideology of seduction and the concept of the challenge are similar, the most obvious difference between the two is that in the challenge "one draws the other into one's area of strength" while seduction "draws the other into one's area of weakness. A calculated weakness, an incalculable weakness: one challenges the other to be taken in" (83).
} 


\section{Difference and Feminism}

What does the women's movement oppose to the phallocratic structure? Autonomy, difference, a specificity of desire and pleasure, a different relation to the female body, a speech, a writing — but never seduction (8).

-- Jean Baudrillard

Seduction

According to some feminists, women are socially and culturally subordinated through essentializing claims about their physical, biological, class, and cultural difference from men. Theorizing about "difference" varies along a pendulum of opposing extremes: from assertions that deny difference between men and women, asserting women's equality to men on masculine terms, to a rejection of masculine terms in an attempt to elevate the feminine as both different from and superior to the masculine, to a recognition of the differences between women which rejects essentializing about what constitutes both "woman" and the "feminine." Feminists who reject the concept of difference by arguing for male and female equality will be addressed in chapter 2 . Here I would like to focus on French feminists Hélène Cixous and Luce Irigaray who sought to create a female writing and speech (respectively) in ways that would celebrate and empower women based on their difference, and in an effort to privilege writing over the materialism of bourgeois egalitarian feminism. In the late 1970s French feminism brought about a change in language, from talking about "the female" to talking about "the feminine" (the French language makes no distinction between the two). Initially this set up a divide between the French and the Anglo/American feminists who saw the French feminists who focused on difference as supporting the male/female dichotomy. I would 
argue that this divide results primarily from productive reading practices: feminists who search for a coherent ideology and a rational unifying argument, who accept the value of writing to the extent that it remains rigorous in a linear quest for meaning. These are, of course, exactly the productive practices that Hélène Cixous and Luce Irigaray are struggling against with their experimental texts regarding écriture féminine and parole de femme respectively. Until feminism recognizes the importance of the linguistic shift, we too will continue to perpetuate the writing and reading strategies of domination and hierarchy, as I will explain.

Strangely, Victoria Grace makes no reference to Cixous in her work on feminism and Baudrillard. I say "strangely" not just because Cixous is one of the most seductive feminist writers to emerge since Virginia Woolf, but also because Cixous was writing during the same time as Baudrillard and their positions are undeniably similar. Seduction (1979) makes little mention of Cixous's “The Laugh of the Medusa” (1976) except by way of a cryptic nod, "What does the women's movement oppose to the phallocratic structure? Autonomy, difference, a specificity, a writing - but never seduction" (8). Cixous is the most significant feminist to discuss feminine writing. So I find her absence from Grace's book strange, particularly as Grace remains sensitive to Baudrillard's mention of Irigaray.

In “The Laugh of the Medusa" (1976), Hélène Cixous describes écriture féminine as writing the female body, and argues that women should write their experiences of the 
body in order to counter masculine representation of the feminine. ${ }^{12}$ Feminine writing of the body could be read as essentialist, an argument Toril Moi makes in her assertion that “within [Cixous's] poetic mythology, writing is posited as an absolute activity in which all women qua women automatically partake" (123). But the argument that écriture féminine is essentialist is a vast oversimplification, which short-circuits our reading of Cixous's work. Cixous does not argue that all women employ feminine writing any more than she seeks to establish a definition of feminine writing: "It is impossible to define a feminine practice of writing, and this is an impossibility that will remain, for this practice can never be theorized, enclosed, coded - which doesn't mean that it doesn't exist" (883). Feminine writing is a practice not an essence. Moreover, feminine writing is a practice that cannot be defined, and rejects the coded or binary structure, analysis for meaning, and interpretation. As such, Cixous's call for feminine writing is a call to writing that resists the coherence imposed by masculine modes of production such as publishing houses and universities.

Moi's argument that, in creating a writing of the body, Cixous assumes a universal body for all women is similarly a gross overgeneralization caused by the slippage between "woman" and "the feminine." For Cixous refuses to define what she means by the body: "body (body? bodies?), no more describable than god, the soul, or the Other" (882). Feminine writing resists definition, signification, and meaning. More to the

\footnotetext{
${ }^{12}$ I am not the only feminist to note a similarity between the work of Baudrillard and Cixous. In Sex, Work, and Sex Work (2003), Joanna Brevis and Steven Linstead argue, "Cixous and Baudrillard, then, reject the idea that there is an essentially common core to human sexuality, that we possess a natural desire for particular forms of sex. Instead they posit that what we come to think of ourselves in this way because we are constituted as individual subjects through the operation of prevailing discourses" (161).
} 
point, feminine writing exposes the fallacy that without an insistence on the production of meaning, nothing would exist. For Cixous's words are there on the written page. In addition she challenges the insinuation that she is some idealistic "mystic," a charge to which she answers, "and what about the libido?" (891). The implication here is strong: masculine theories of sex and sexuality are also discourses of idealistic mysticism, but the fact that they insist upon their own truth, their own reality, through a coded structure is what gives these theories their power, which is then used to discriminate against and subordinate those who do not conform to the law of the "real."

Cixous thus criticizes first and second wave Anglo/American feminism for perpetuating these productive discourses as truth, for worshiping the "phallic stance":

Yes, the naives to the first and second degree are still legion. If the New Women, arriving now, dare to create outside the theoretical, they're called in by the cops of the signifier, fingerprinted, remonstrated, and brought into the line of order that they are supposed to know; assigned by force of trickery to a precise place in the chain that's always formed for the benefit of a privileged signifier. We are pieced back to the string which leads back, if not to the Name-of-the-Father, then, for a new twist, to the place of the phallic-mother. (892)

For Cixous, women, in privileging masculine theories (economic, sexual, linguistic), support power structures, masculine or feminine, which feminists should break down altogether. She argues that either in privileging masculine discourse women are subjugated to that structure or, in opposing the structure, set up another hierarchy. Understanding that women are bound to language which always privileges men and power, and similarly to Virginia Woolf, Cixous argues for writing, laughter, and disinterest as responses to phallocratic structures: "If she's a her-she, it's in order to smash everything, to shatter the framework of institutions, to blow up the law, to break up the 
'truth' with laughter" (888). ${ }^{13}$ The notion of the "her-she" resembles Woolf's, “outsider society" because it is a term that establishes an outside to the system of meaning, definition, hierarchy, and organization whereby women play with the system rather than opposing or espousing it - they refuse to play its game. In a rare moment of instruction, Cixous advises the "her-she" to "take pleasure in jumbling the order of space, in disorienting it, in changing around the furniture, dislocating things and values, breaking them all up, emptying structures, and turning propriety upside down" (887). This outsider position breaks down the accepted beliefs of what constitutes writing, sex, and the body through laughter, the game, the challenge, and artifice. The rational search for order is the impetus behind ideologies that impose power structures upon the disempowered. Cixous's position makes no claims to truth and supports no existing truth. This is seduction-implemented before Baudrillard ever published his own theory. This is feminine writing and as such non-productive.

Like Cixous, Irigaray appeared to support the notion of difference. Although Cixous saw difference in writing (masculine/feminine), Irigaray argued for essential (and arguably - but not necessarily - essentialist) differences between men and women. In This Sex which is Not One (1977), Irigaray both argues against Freud's notion that

\footnotetext{
${ }^{13}$ I do not make the claim that Cixous is drawing from Woolf in her plea for laughter, merely that there is an epistemology of feminist laughter that bears attention. Consider the fact that in "Womanliness as Masquerade," Rivière also discusses a woman, a university professor, who is prone to laughter when addressing the all-male faculty members at her university, "She becomes flippant and joking, so much so that it has caused comment and rebuke. She has to treat the situation of displaying her masculinity to men as a game, something not real [sic], as a "joke"' (308). This example has political implications: what frustrates masculine ideology is the refusal to take productive ideologies seriously.
} 
anatomy is destiny, and argues that "Parole de Femme," or womanspeak, is anatomicalonly women can speak and understand it. When Baudrillard accuses feminism of working against itself, he tends to blame French psychoanalytic feminists in general and Luce Irigaray in particular. He argues that if her aim is to reject Freud's claim that anatomy is destiny, she is going about it all wrong: "Parole de femme? But it is always an anatomical speech, always that of the body" (9). Although as Baudrillard proclaims, Irigaray's theory appears to be a contradiction, her argument is quite subversive. An important role model for Butler's clown, Irigaray, like Cixous and Woolf, is a strong proponent of laughter in response to masculine subject positions and, as such, she invites seductive readings of her text. In This Sex Which is Not One, Irigaray argues that, "to escape from a pure and simple reversal of the masculine position means in any case not to forget to laugh" (163). In reading this quotation, and recognizing that Irigaray counts among a list of feminists who reject a productive economy, I argue that Irigaray does not seek to establish a universal truth about women in her theory of "womanspeak." On the contrary, reading her in conjunction with Woolf and Cixous, it appears that Irigaray rearranges the furniture, discombobulates values by which universal truths about women become established.

In Speculum of the Other Woman (1974) Irigaray argues that women exist in culture as that which remains outside of representation. "Woman" is the narcissistic object for the male, necessary to the creation of a masculine subject that can reflect upon its own being, his “specularization." Irigaray argues that the ability to think selfreflexively is integral to philosophy. Women thus become the mirror through which man 
comes to "know" himself. In her attack on Freud, Irigary argues that "Three Theories of Sexuality" is misogynist to the extent that it re-inscribes the little girl as a little man who matures to the realization that she lacks masculine power (defined as penis envy). Irigaray argues that Freud's theory does not describe the sexual maturation of the female so much as it negates the female body in such a way to make it a "negative" mirror onto which the male may reflect himself as positive. Irigaray thus describes the notion of "penis envy" as the productive concept used to elevate masculine ego. As a system of meaning making, specularization is incapable of thinking outside of self-reflection. Women, under specular patriarchy, have only two options: to remain silent (defined not as the lack of language but as incomprehensible language - incapable of being understood in the structure of masculine discourse), or to mimic the language of specular ideology. $^{14}$

Toril Moi argues that what Irigaray does in Speculum of the Other Woman is to "mime male discourse" or more specifically to "mime the miming imposed upon women" in a way that "reinforces patriarchal discourse" through the creation of a feminine sexuality that is inclusive, plural, and multiple (140). Moi's conclusion about Irigaray's "mimesis," and thus her perpetuation of masculine discourse, comes mainly from the fact that Irigaray states only two options for women. So Moi sees only these two options. But, in my view, while Irigaray posits only two options, she suggests a third in her writing, one that she does not name. For mimesis implies a recreation of masculine discourse on its own terms, productive terms, which Irigaray argues against vehemently. If Irigaray

\footnotetext{
${ }^{14}$ I will take up this issue of silence in my fourth chapter.
} 
were miming masculine discourse, such as that of Freud or Marx, in Moi's sense of “miming," then her writing would be expository, employing classification and deductive reasoning, and yet Irigaray's writing is performative. That is, she would perform the ways in which meaning and truth become inscribed culturally. The difference between mime, mimicry, and mimesis cannot be underestimated. While all three may entail imitation, miming is playful and parodic. Indeed, a mime is a clown.

Irigaray asserts her female origin story as deriving not from pre-historic man but from myth, specifically, the myth of Plato's cave. In Speculum of the Other Woman, Irigaray effectively shows that all origin stories derive from myth, and become perpetuated as reality in discourse:

Being is thus already caught up in a speculum ... 'Origin' that interacts with Being each cover over, disguising and supporting the other. Finally Being does not appear or even appear to appear. It slips away from the mind's grasp, even as it forms the foundations of the mind. (150)

"Origin" stories that claim to assert "being" are, for Irigaray, self-reflexive. What philosophers assert as "truth" is situated in a time before social intervention and then represented, recalibrated as a more natural form of man from which philosophy derives. Nothing new can appear in this system. It is a speculative dead end in which the philosopher sees himself mirrored in everything. Here Irigaray shows the ways in which pre-social existence is a myth in itself from which other myths emerge and become argued as Truth. Irigaray's argument about the nature of women as plural, fluid, and inclusive is another myth. She makes no claims to its reality or to what it produces. She is holding up a parodic mirror in the hope that philosophers will step back and take a look at themselves and their processes of meaning making, which prohibit them from thinking 
outside the speculum, outside the productive, much like the cat that looks at the naked Derrida, a look that Derrida says philosophers from Descartes to Levinas have failed to confront. $^{15}$

Carolyn Burke argues that Irigaray in "Romancing the Philosophers: Luce Irigaray" is "Having a fling with the philosophers, seducing them on their own ground," and that this "was the only recourse of the feminine, given the position to which it was relegated" (228). But while Burke argues that Irigaray's desire is to "beguile her philosophical partners into a recognition of sexual difference," I argue that Irigaray uses their formulae in a way that exposes the weakness of philosophy's claim to sexual difference (229). Irigary's “origin" story is a parody of the "origin” stories, a kind of theatricality that she sees created by philosophers that have come before her. How can she possibly find an "origin" story in a fictive account of history? She is not asserting a truth about woman's beginning. She is exposing the fictive nature of all beginnings. She exposes their imaginary nature by playing with the way the truth of identity and difference are established. Apparently philosophers including even Baudrillard miss the political implications of their own mythmaking because they do not see themselves reflected in her parodic writing. Ironically, Baudrillard himself indicates that seduction works such that the man/philosopher is unaware of and incapable of seeing his own seduction.

This Sex Which is Not One is a further attempt to void the structures of masculine philosophy. In this decisive work, Irigaray establishes a more clearly defined outsider

15 See "The Animal that Therefore I Am (More to Follow)." 
position to masculine systems of meaning making through her theory of womanspeak or Parole de Femme. In This Sex Which Not One, Irigaray exposes the fact that, contrary to Moi's reading, her textual-politics are not that of mimesis, for she more clearly aligns herself within the position of "silence," or that babble which a masculine economy cannot understand. Irigaray argues that womanspeak is "her language, in which 'she' sets off in all directions leaving 'him' unable to discern any coherence or meaning” (29). More clearly aligning herself with Cixous, Irigaray uses womanspeak to deny phallocratic philosophy its will to knowledge. Thus "womanspeak" becomes a site of frustration for a system that claims to "know," and thus dominate women. Although Baudrillard attacks Irigaray, his entire argument about seduction is that it plays with appearance-thus resisting both "meaning" and "truth." While what Irigaray says may seem to play into Freud's claim that anatomy is destiny, what she does, one might argue, is to seduce. Irigaray writes:

It is therefore useless to trap women into giving an exact definition of what they mean, to make them repeat (themselves) so that meaning will be clear. They are already elsewhere in the discursive machinery where you claim to take them by surprise ... If you ask them insistently what they are thinking about, they can never reply: nothing. Everything." (29)

Here Irigaray outright refuses definition, refuses to take part in the repetition of productive discourse, systems of meaning making, or clarification. Womanspeak is thus a position outside masculine economy. Perhaps what actually frustrates Baudrillard about Irigaray is the fact that she has out-seduced him - excluded him from her discourse - by making it incomprehensible to him. 
More sympathetic to French feminism than Baudrillard, Toril Moi aligns herself with the French feminists to the extent that they recognize feminism as a textual politics. Moi favors the French over the Anglo-Americans because, she argues, sexual politics must be understood in terms of writing - textual politics - and not just in terms of positions, arguments, and policies. Cixous and Irigary both critique, or "un-think" to use Cixous's term, power structures, break down hierarchies, and expose the weakness of phallocratic systems of meaning making. However, in Sexual/ Textual Politics, Moi's more Marxist position becomes frustrated by both Irigaray and Cixous when she encounters their constant use of myth, their resistance to analytical interpretation, and their refusal to think rationally. Moi’s argument that Irigaray cannot pretend to write in some "feminist realm outside of patriarchy" is humorous when viewed from the standpoint that what frustrates Moi most about both theorists is that they are not conforming to productive discourses: rationality, clear analysis, structure, and reality (140). It is not that they cannot write from this position, it is that feminists who acquiesce in the value of productive writing will not let them.

Perhaps Moi's most vehement argument with French feminists is that what she sees as their lack of engagement with material differences among women and thus their theories cannot initiate social change. Of Irigaray's work, Moi complains:

The material conditions of women's oppression are spectacularly absent from her work. But without specific material analysis, a feminine account of power cannot transcend the simplistic and defeatist vision of male power pitted against female helplessness that underpins Irigaray's theoretical investigations. (147) 
Here Moi accuses Irigaray of perpetuating her theory about the "specular" nature of masculine philosophy by refusing to take into account women's material oppression. But Irigaray's argument about the "specular" nature of philosophy is that it looks to "the other" to speculate upon itself. Irigaray does not perpetuate "specularization" precisely because she does not look to the material representations of "the other" in order to reflect upon herself (as woman). As to Moi's assertion that female helplessness underpins Irigaray's work, I cannot agree. Irigaray's work is reflective of (in the sense of holding up a mirror to) the helplessly circular nature of masculine philosophy, which her intervention of "womanspeak" and her concept of the "specular" reveal and devalue as "philosophy."

Irigaray and Cixous are seductive to the extent that their writing is, in Victoria Grace's definition of the term, "precisely not the order of representation" (Grace 142). Moi believes, like De Beauvoir, that men reduce women to objects: that is, women have been constructed through language as man's other and thus denied the right to subjectivity. Thus Moi argues that feminists should take into account the material conditions of real women. Moi's does not give an example of what this kind of reading practice or textual politics would look like. She does not explain how feminists who write about the real conditions of women come to "know" what these "real" conditions are. Had Moi provided an example of such a practice, she might have fallen into the same trap as those masculine authoritative voices that feminists deem incompetent to represent woman. That is, the masculine claim to authority, the power to analyze, represent, and make meaning is, according to Cixous and Irigaray, what feminists should decry, expose 
as imaginary and empty of meaning. As Donna Haraway argues, the "vulgar Marxist

mistake" is "deriving directly the substance of knowledge from material conditions" (12). Irigaray and Cixous perform a much more radical task. They deny both representation and reality. They present a challenge to the masculine desire for women's know-ability. What politics follows from this, Moi might ask: Nothing - no one thing, no alternative practice. Moi succumbs to the myth that textual politics could be a real politics. Irigaray and Cixous refuse to participate in the productive model.

Rosi Braidotti and other feminists have acknowledged the value of the work of Cixous and Irigaray but only by focusing on their claims, arguments, and positions. The work of Cixous and Irigaray is helpful in combating the historical oppression of gendered, racialized, and sexed bodies. A feminist focus on positioning, on ordering and classifying French feminist discourse, has been in an effort to rearticulate the subject as positive, multiple, fluid and "anti-essentialist." While this has proved a useful tool for feminist analysis, it too obeys the productive model. Few feminists actually take up the seductive writing and reading practices of Irigaray and Cixous. I would argue that the reason for this is that seductive writing has little or no economic value according to the rules and guidelines of publication houses and university presses. As Rosi Braidotti points out:

Irigaray has never held a tenured teaching position in any institution, and Cixous teaches in a secondary, underprivileged university. This makes their agendas anything but prestigious and influential, but it has the advantage of freeing them for political activity. (24)

While the French feminists are "free" to engage in political activity, in that they are not required to perpetuate the value of productive reading and writing practices, privileged 
university feminists are compelled by tradition to propagate productive reading and writing practices at the same time that we recognize the oppression of productive structures.

Yet the implication that the writing of Irigaray and Cixous has the capacity to free them for political activity is a red herring - much like the value of feminist studies in the academy. While we acknowledge their positions as beneficial, their writing practices are missed. The perpetuation of productive strategies in academia does remain a testament to the fact that academic feminist theorists are less free for political activity, and we struggle to articulate our own value on the basis of our ability to produce in ways that allow us to achieve tenured positions. Virginia Woolf asserts that though women have the ability to publish their concerns in the press, they are still bound to the structures for writing and argumentation that is favored by these presses. Thus, where seduction occurs in more contemporary feminist theory, it is couched behind productive discourses, discourses which pretend to imitate productive reading and writing practices while simultaneously undermining and critiquing them.

\section{Knowledge/Knowing/Known}

The body is made to signify, but with signs that, strictly speaking, have no meaning. All resemblance has vanished, all representation is absent. The body is covered with appearances, illusions, traps, animal parodies and sacrificial simulations, not in order to dissemble, nor reveal (a desire say, or a drive), not even just for fun ... For nothing exists naturally, things exist because challenged, and because summoned to respond to that challenge.

-- Baudrillard 
For many feminists, such as Donna Haraway, knowledge is a dangerous term. On the one hand, knowledge, or education, has been historically denied to women. On the other hand, knowledge has been used to naturalize female oppression. Since Simone De Beauvoir, feminists have articulated the problematic nature of masculine knowledge whereby scientific discourse, for example, insures that the descriptions of reproductive organs reinforce the appropriate gender roles for men and women (the egg is passive while the sperm as active). The task for feminism has often been not only to critique the discriminating discourse of knowledge, but also to struggle for feminist alternatives to phallocentric knowledge and language. Around the second wave this resulted in alternatives like herstory, gyn/ecology, and the gender-neutral pronoun s/he. But Haraway points out that while feminism is, in part, an effort to reconstruct public life and public meanings, and thus an effort at a new language and a new knowledge, we must also tread lightly when asserting any truth: "Feminists also know that the power of naming a thing is the power of objectifying, of totalizing" (72). For Haraway, we, as feminists, must realize that our own attempts to re-construct knowledge is always fictive in the same way that scientific discourse is fictive. Although feminism is at the same time a struggle for knowledge and against productive knowledge, we must assume that any new formula construed as knowledge will continue to discriminate and to marginalize as these effects are imbedded in the political backslash of the binary opposition knowledge/ignorance. 
In a sub-section entitled "The Dissolution of Power and Meaning in the Illusion of the Real," Victoria Grace argues that Donna Haraway provides "one tiny example of a point of connection with Baudrillard's work" (190):

Her 'Manifesto for cyborgs' shows a determination, like Baudrillard's, to develop an analysis that is grounded culturally and specifically. There is evident in Haraway's work none of the universal questions or constructs that tend to creep into the works of those other feminist theorists discussed. $(188)^{16}$

Grace appreciates the fact that Haraway recognizes a contemporary decline in universalizing discourse, in the use of the origin story, in questions of "totalizing epistemologies," and in "politics defined through immobile identities" (189). But Grace also points to the fact that Haraway's focus on the "specific" establishes a binary opposition with the "universal." Her other complaints against Haraway include: Haraway's cyborg transgresses the boundaries that construct the human but does so "in accordance with the law" (189); the question of "political struggle" goes unquestioned by Haraway; Haraway establishes categories (a chart) describing what we have moved away from (representation) and what we have moved to (simulation) without theorizing the shift; Haraway does not reference Baudrillard (except in her definition of simulation) though her use of language makes his influence undeniable; ${ }^{17}$ and finally, she is too

\footnotetext{
${ }^{16}$ Although Grace keeps Haraway's cyborg from entering into a conversation with Baudrillard, other theorists recognize a profound connection. See for example, Rita Felski's Doing Time: Feminist Theory and Post-Modern Culture (2000); and Kim Tofoletti's Cyborgs and Barbie Dolls: Feminism, Popular Culture and the Posthuman Body (2007).

${ }^{17}$ I would point out that Haraway and Baudrillard are similar in one other way. That is, Baudrillard did not reference Rivière in Seduction except in her definition of
} 
optimistic, something which is not directly asserted but rather implied by Grace's argument that "Baudrillard is less optimistic" (190).

Focusing exclusively on Haraway’s Cyborg manifesto, Grace elides the work that comes before it, which sets up some important points that I think are necessary to understanding the potential and the limits of the cyborg as myth. Like Baudrillard, Haraway believes that all "liberation" movements focused on gender difference must acknowledge the productive history that instantiates that difference in the first place. In her chapter “'Gender' for a Marxist Dictionary,” Haraway notes:

Since the concept of gender is so closely related to the Western distinction between nature and society or nature and history, via the distinction between sex and gender, the relation of feminist gender theories to Marxism is tied to the fate of the concepts of nature and labor in the Marxist canon and in Western philosophy more broadly. (131)

Haraway, like Baudrillard, locates the history of gendered and racialized oppression within Marx's coded productive discourse, which sought to explain social relations through labor and production. Marx's writing is largely responsible for the distinction between subject/object that has come to be associated with the male/female or masculine/feminine divide. This structure instantiates the difference between women and men not only as evidenced by their productive potential, whereby the men are active producers and women passive objects, but also as naturalized - whereby women become linked to nature, which can be both manipulated and subordinated for masculine use. A woman's value in this structure is limited to her potential use as a sign of masculine power. The fact that Haraway recognizes feminist conceptualization of gender as "tied to womanliness. It seems like poetic justice, then, when Haraway does not reference Baudrillard in her work on cyborg except through her definition of simulation. 
the fate of ... the Marxist canon" (131) not only shows the ways in which feminist work on gender inevitably recycles the political backslash of oppression, but also shows her dedication to going beyond such a coded productive structure. More to the point, Haraway expresses a need to move beyond such oppressive "fate." Change cannot be effected through fated discourse.

The difference between Haraway's writing in “"Gender' for a Marxist Dictionary” and her use of language in the following chapter "A Cyborg Manifesto" merits some attention. Where the former sets up distinctions and makes arguments (productive writing), her engagement with the Cyborg exposes language itself as the site of potential subversion (seductive writing). Haraway claims:

Cyborg writing must not be about the fall, the imagination of a once-upona-time wholeness before language, before writing, before man. Cyborg writing is about the power to survive, not on the basis of original innocence, but on the basis of seizing the tools to mark the world that marked them as other. (175)

Writing, the tool that Haraway seizes in her manifesto, has radical potential to the degree that it does not aim at organic wholeness, but instead embraces artificiality, prodigality, play and limitation. Much like Baudrillard's claim that seduction is different from challenge in that seduction seduces with weakness by bringing the other into one's area of weakness, cyborg writing exposes the weakness of arguments that claim to beginnings and origin stories through both the cyborg's refusal to engage in productive discourse and through the relegation of productive discourse to the realm of the fairy tale. Cyborg writing is not about aiming at the truth behind the fairy tale but rather invokes another 
fairy tale that limits the potential for instantiating truth-claims. Haraway's cyborg is less a metaphor than a practice.

To recognize the cyborg as a practice is critical at this juncture of feminist thought because to argue that the cyborg is a metaphor is to limit its radical potential; current cyborg theorists are threatening to normalize and canonize a reductive use of it. In "Witnessing the Postmodern Jeremiad: (Mis)Understanding Donna Haraway's Method of Inquiry” (2001), Ingrid Bartsch, Carolyn DiPalma, and Laura Sells argue that,

Even though Haraway herself clearly sees the importance of constantly shifting metaphors to prevent such a fate, the cyborg has become literalized. Indeed, it now serves as the icon or figurehead for a loose confederacy of cyborg scholars who align themselves and their theoretical interests with the work of Donna Haraway. This is evident in the number of academic publications and conference papers that jockey the cyborg's currency in academic discourse. Unfortunately, this very currency also undermines its rhetorical power and concomitant liberator potential through an overuse that fixes and literalizes its meaning. In many ways, then, it is a dead metaphor. (141)

This critique brings us back to the earlier insight of Virginia Woolf and Luce Irigaray: that our academic work itself reiterates the productive discourse feminists would like to escape. The cyborg has become a portmanteau for productive meaning. A seductive reading of the cyborg is dedicated not to imposing meaning upon the myth of the cyborg, asserting what the cyborg means for a postmodern society, but rather to recognizing that such meaning will instantiate the cyborg as real, as another productive ideology which, on the contrary, the figurehead itself is concerned with dismantling.

I remain unconvinced by Grace's statement that the cyborg transgresses boundaries "in accordance with the law." Where Grace defines the law as "the bar that structures identity/difference, subject/object" (188), it seems to me that Haraway is less 
guilty of instantiating binary coded meaning than her critics and followers. ${ }^{18}$ Careful attention to Haraway's discourse exposes a refusal to instantiate meaning and value at every turn. Haraway asserts in the introduction to "A Cyborg Manifesto" that her work is an effort to "build an ironic political myth faithful to feminism, socialism, and materialism" (148). That is, Haraway contradictorily recognizes a certain responsibility to political frameworks (particular strands of feminism, socialism, and materialism) that are responsible for the political backslash of hierarchy and domination, which she simultaneously seeks to weaken through irony and myth. Readers should be wary of Haraway's assertion of faithfulness to these ideologies in much the same way that psychoanalysts should be wary of Rivière's asserted dedication and devotion to the work of Ernest Jones. Haraway addresses the incompatibility of her endeavor and her faithfulness when she later asserts, "irony is about contradictions that do not resolve into larger wholes ... about the tension of holding incompatible things together because both or all are necessary and true" (148). Haraway's writing, then, is an attempt to join together opposing ideologies, not in an effort to show the similarities between opposing discourses but in an effort to show the ways in which these opposite truths have the radical effect of canceling each other out. If all ideologies are necessary and true, and yet they are opposing and incompatible, then none of them are true. Haraway's refusal to

\footnotetext{
${ }^{18}$ In " A Family of Displaced Figures': an Overview of Donna Haraway" (2008), Sherryl Vint argues that "Haraway's own work has moved beyond the cyborg, continually seeking out new figures who might serve as equally potent metaphors to explain the ever shifting terrain of our technological, political, economic and social landscape" (290). Could the need to instantiate new possibilities, new figures, stem from the fact that Haraway's "cyborg" is now dead because it has been over-signified as a metaphor and used as an explanation for actual realities?
} 
privilege one ideology over another exposes her claim that "both or all are necessary and true" as another irony. That is, all ideological discourses - feminism, socialism, and materialism - have their own claims to truth. It is the claim to truth that makes them true and not their ability to articulate the world faithfully. To hold these opposing ideologies in tension without resolving them is to resist allowing any ideology the truth that it would like to proclaim.

In describing the work of the fictive cyborg, and the equally fictive universe that it belongs to, Haraway writes that her imagined creation:

is a creature in a post-gender world; it has no truck with bisexuality, preoedipal symbiosis, unalienated labor, or other seductions to organic wholeness through a final appropriation of all the powers of the parts into a higher unity. In a sense, the cyborg has no origin story in the Western sense. (150)

If the cyborg is post-gender, then it cannot conform to the masculine/feminine divide. If it has no truck with bisexuality, then it does not acknowledge the homosexual/heterosexual divide. If it is uninterested in un-alienated labor, then it ignores the use/exchange value binary upon which Marxism, along with the entire notion of the subject/object divide, relies. Furthermore, the cyborg establishes no relationship with Foucault's notion of biopolitics, technologies of power which manage people as a group. Finally, the lack of origin story cannot confirm masculine domination of woman/nature. The focus of this passage is less on what the cyborg is (a potent fusion of machine and animal, human and nature), or on its status as a metaphor for reality in a technological age, than what the cyborg does. The cyborg, as a practice, moves away from identification with productive discourses that instantiate truth claims. The fact that the cyborg has no origin story should 
be proof that it is not a metaphor for actual lived beings or social realities but rather an informed and rebellious writing practice. The cyborg becomes less a noun than a verb: to "cyborg" is to radically undercut productive writing and reading practices.

If Haraway’s cyborg is, as Grace suggests, transgressing boundaries “according to the law," then it is no law established through Western discourse. For the ideology of Western discourse relies on distinctions while Haraway's writing relies on contradictions. Haraway goes on to argue that "the main trouble with cyborgs, of course, is that they are the illegitimate offspring of militarism and patriarchal capitalism, not to mention state socialism. But illegitimate offspring are often exceedingly unfaithful to their origins" (151). The cyborg simultaneously has no origin, is the illegitimate offspring of the "isms," and is unfaithful to its origin. The tension between having no origin and being unfaithful to an origin is never resolved. Haraway states earlier in her essay that her writing is an attempt to remain "faithful" to socialism, even while her cyborg is "exceedingly unfaithful" to socialism. Haraway states that her cyborg myth is about "transgressed boundaries, potent fusions, and dangerous possibilities," but she also argues that the myth "might be about lived social and bodily realities in which people are not afraid of their joint kinship with animals and machines not afraid of permanently partial identities and contradictory standpoints" (154). When coupled with the fact that the cyborg is a fiction, the presence of such a "reality" can also only be a fiction. The bodily reality of the cyborg becomes the empty signifier. We hold the incompatible being in our head while the discourse itself works itself around us to radically undercut productive discourse. If Haraway is faithful to socialism and feminism then we feminists 
have nothing to fear from its discourse. The cyborg as a body is a smoke and mirror effect that holds us captive while the language itself denies any possibility for making the cyborg manifest in our minds.

Haraway's repetitive use of unsettling contradiction is, of course, done on purpose and in an attempt to forestall the meaning that has (at any rate) been imposed upon her through productive discourse (be that an argument that she is "optimistic," that her cyborg is a metaphor, or that she establishes a binary of any kind). As Haraway argues:

The world is subdivided by boundaries differently permeable to information. Information is just that kind of quantifiable element (unit, basis of unity), which allows universal translation, and so unhindered universal power (called effective communication). The biggest threat to such power is interruption of communication. Any system breakdown is a function of stress. (164)

What Haraway performs in her manifesto is a repetitive breakdown of effective communication and systems for knowledge (feminism, socialism, and materialism), through both irony and contradiction. Insisting on her devotion to contradictory ideologies serves to distract attention from her subversion. I would argue that Haraway's invocation of the "manifesto," traditionally invoked to declare one's principles and intentions, is similarly an ironic move, because Haraway's principles are tensions and her intentions are contradictions.

Integral to the concept of the cyborg is the ideology of cyborg writing, the political tool of the cyborg used as a "struggle against perfect communication, against the code which translates meaning perfectly, the central dogma of phallocentrism" (176). The cyborg as a bodily reality or a lived possibility is a red herring - that little bit of “womanliness" which distracts her reader while Haraway's writing unsettles ideologies' 
claims to truth. The cyborg itself has reached epic proportions in the academy where we now question: What is the cyborg? Who is the cyborg? Where is the cyborg? All the while the actual writing of the cyborg refuses our desire to know. As long as these questions remain unanswered, the radical potential of the writing itself continues to function in discourse. But to foreclose such knowledge by articulating the cyborg as metaphor for $\mathrm{X}$ is to instantiate the cyborg into productive discourse, to render it innocuous, dead, and an archaic artifact of the past.

Although I have structured each subsection of this chapter according to popular productive ideologies with which feminists must continually grapple-issues of equality, the feminine, identity, difference, and knowledge - I have done so precisely because these productive terms have structured feminism and not because these feminists can be relegated to such categories. Not only are these categories not easily distinguishable rather they bleed into one another - but I would argue that these feminists are not even primarily concerned with the productive concepts in terms of which they are so often read. But can we even imagine a feminist discourse outside of productive discourse? What would it mean to structure feminist discourse around the terms that feminists have created-terms such as "Mulberry Tree," "The Masquerade," "The Clown," and "Laughter"? This would seem to be the logical alternative. However, this would also be a mistake. A theory of seduction, I argue, provides a way of reading feminists that, while highlighting the importance of such terms for feminism, also undercuts our tendency to provide logical alternatives that fall prey to productivist logic. 
What a feminist reading practice of seduction allows us to do, then, is like Virginia Woolf, to remain uncommitted to any one position. That is, seduction as a reading practice focuses on the breakdown of production and productive discourse. Seduction is a means with no end. It is not a reading practice that offers an alternative discourse to the discourses of identity, of representation, of knowledge, or of value. Seduction is a critical term for this juncture in feminist theory. For we should, like Butler, resist any and all intellectual surety that would perpetuate the system of political backslash. To value strength over weakness, to proclaim the truth over the artificial, to move textual politics away from the game and to steer it toward Truth, all of these things threaten to destroy the perpetual motion that is feminist theory. 


\section{CHAPTER THREE}

\section{FROM PRODUCTION TO SEDUCTION:}

\section{WOMEN AND POWER IN THE PROGRESSIVE ERA}

In the last chapter, I argued that productive ideologies structure social systems and recycle oppressive systems of production. I further argued that reading feminist discourse through seduction exposes the ways in which masculine systems of production contain their own foil in and through productive discourse. In this chapter, I take issue with the productive discourse of Progressive Era feminist politics through a seductive reading of Edith Wharton's The House of Mirth. Against a long history of productive readings, which argue that Wharton's novel advocates the same productive feminism of Charlotte Perkins Gilman and other Progressive Era reformers, I read in Wharton's novel a more revolutionary feminist perspective inhering in the characterization of Lily Bart. Lily poses a radical challenge to the oppressive values advocated by Progressive Era reform.

The Progressive Era is primarily imagined as a period of social and labor reform. As such, the social world was inextricably linked to the lexicon of production. ${ }^{1}$ Quite literally one's social value and sense of self-worth were defined in relation to one's work,

\footnotetext{
${ }^{1}$ Even Thorstein Veblen's The Theory of the Leisure Class, characterized conspicuously by non-production, is still linked to this lexicon.
} 
and specifically to what one produced. Progressive reformers sought to rationalize the labor system by investigating, measuring, and classifying the conditions of lower-class working environments in an attempt to assuage an increasingly disparate and volatile class conflict. Elite women reformers such as Jane Addams, Cornelia Stratton Parker, and Charlotte Perkins Gilman played a large part in examining and recording the labor experiences of lower-class women. Specifically, women reformers entered the female workplace, assessed the pay scale and managerial treatment of women, and connected their findings to women's social habits. Many women called for labor reform on the assumption that better working conditions would morally safeguard women. A study of sales girls at Macy's, for example, concluded that women who were well paid were less likely to engage in extramarital affairs with men in order to compensate for their lack of income. ${ }^{2}$ Thus, in the progressive era, reformers dichotomized women's options for gaining social wealth (either through production or though sex, the latter being highly discouraged) while systematically denying any alternative outside of these quantifiable and qualitative social structures.

Because of the substantial body of academic literature by women on women during the Progressive Era, some critics mistakenly see the movement as a feminist one. ${ }^{3}$

\footnotetext{
${ }^{2}$ See “'The Rest Can Go to the Devil:' Macy's Workers negotiate Gender, Sex, and Class in the Progressive Era" by Val Marie Johnson.

${ }^{3}$ For example, Dana Seitler argues that "one of the more surprising aspects of feminist reform campaigns was the frequency with which self-proclaimed feminists like Charlotte Perkins Gilman, Margaret Sanger, and Victoria Woodhull advocated for sexual and economic freedom, reproductive necessity, and eugenic discipline simultaneously" (67, my italics). Although Sietler notices a disjuncture between the ideologies of eugenics and
} 
In her article on women reformers and Progressive Era reform Kathryn Kish Sklar writes, "power defined as the ability to control the distribution of social resources, was more evident in women's activities in the Progressive Era than at any time previous or, some would say, since" (176). For Sklar, then, power is production and production is power. It is this very notion of power, I argue, that explains the palpable contradictions in literature representing the role of women in the Progressive Era. Defining women's power in relation to production does not further women's status in society; it only reinforces the hegemonic notion that production is the only means to social power. In hindsight, a more radical feminist strategy would attempt to break down the idea of production as power because concentrated systems expel and exclude those who do not conform to the hierarchy of value. ${ }^{4}$ Moreover, production is a model for social domination. Therefore, women who do not define themselves as a productive labor force cannot find wealth and power in a social system that excludes them-or at the very least, where they rank lower on the productive scale than men. As I show in this chapter, there is no language with which to define women as powerful in Progressive discourse insofar as it establishes production as the only means to material gain and social worth. Through analysis of the

feminism, issues of sexual and economic freedom remain unquestioned because these aims of feminism are seemingly unproblematic and self-evident.

${ }^{4}$ Shulamith Firestone, in The Dialectic of Sex: The Case for Feminist Revolution, states that radical feminism "sees feminist issues not only as women's first priority, but as central to any larger revolutionary analysis (such as the labor problem and labor reform)... it sees the current leftist analysis as outdated and superficial, because this analysis does not relate the structure of the economic class system (and I would further argue the system of production) to its origins in the sexual class system, the model for all other exploitative systems" (37). Although Firestone defines this feminism as "radical" in the 70's, I use that modifier as a general working definition of feminism today. 
literature of women reformers such as Charlotte Perkins Gilman and Cornelia Stratton Parker I argue that the Progressive Era was a period of strategic female disempowerment irrespective of class and social hierarchy.

As I discussed in chapter one, in The Mirror of Production (1973), Baudrillard argues that Marx, in failing to conceive of a possibility for social wealth and value outside of labor and production, did not offer a radical alternative to capitalism. Essential to understanding his later work on seduction, Baudrillard argued in this earlier work that society is dominated by the ideology and power of production (our multifarious systems for making meaning - semiotics, economics, psychoanalysis). Marx assumed "production" as a natural given, a quality of man that separates him from objects and animals. The system of political economy "is what produces the very conception of labor power as the fundamental human potential" (31). According to Baudrillard, Marx was not describing the natural condition of man; he was creating it. Shattering Marx's "mirror of production" requires a two-fold process: recognizing that labor is not natural, and rejecting the concept of identity based on the subject/object divide as he does in Seduction (1979). If I turn to Seduction in my reading of progressive era feminism, it is because this is where Baudrillard refines his critique of production.

Because feminists and social reformers of the progressive era were, like Marx, heavily immersed in the ideology of production and the social value of labor, they unwittingly end up perpetuating discrimination against those women who do not conform to the social value of labor. Cornelia Stratton Parker, for example, was a labor reformer who recorded women's experience in the workplace with the goal of establishing better 
relations between workers and management. In the introduction to Working With the Working Woman (1922) Parker writes, “There could be no more dynamic subject than labor, since labor is human beings, and what is more dynamic than human beings?" (vii). This quotation articulates the motivation behind Parker's decision to pass as a lower-class woman and enter factories in an effort to investigate the social habits of working women. But the assumption that one $i s$ what one does, implicit in her equation of labor and human beings, is highly problematic. Baudrillard defines labor as "what disinvests the body and social exchange of all ambivalent and symbolic qualities, reducing them to rational, positive and unilateral investment" (46). That is to say, we cannot learn anything about social beings through their productive labor, we can only learn about labor. In privileging the notion of production in writing about women, Parker sets up a hierarchy of discourse in which women will systematically fail to be seen as empowered. What begins as an investigation of the experience of working women ultimately becomes a treatise on labor. In privileging the notion of productivity over all forms of social worth, Parker naturalizes the desire to work: "First, it is part of every normal human being to want to work. Therefore women want to work" (p. xvi). For Parker, production is what allows a woman to fulfill the desire that makes her human, contributing to society on a par with men. When the chocolate factory worker Lena claims the appeal of a leasure-class existence, Parker quickly corrects her mistake. "Lena claimed, if she could have her way in the world, she would sleep till 12 every day and go to a show every afternoon. But that life would pall even on Lena, and she giggled wisely when I slangly suggested as much” (38). The fact that Parker has to remind Lena that a life of luxury would "pall" exposes 
the purpose of labor reform: it was not to just to improve working conditions but also an effort to make factory workers satisfied with their lot in life. In seeking to define women by their desire to work, Parker articulates the strength and universality of the power of production and risks identifying all other desires as unnatural. ${ }^{5}$

In arguing that "labor" is natural, Parker establishes social wealth and self-worth as an end and not a means. That is, labor becomes its own reward and there is no longer any desire to imagine social mobility. To accomplish this goal, Parker examines the "unproductive" nature of academia. When, after working in the chocolate factory, Parker returns to campus to attend a college lecture on "The Role of the State in Modern Civilization," she expresses impatience with the academic inability to speak on any topic with absolute authority. Parker writes,

Thus it is with much which one studies nowadays. We have evolved beyond the era of intellectual surety. What an almighty relief to the soul, then, when one can pack six rows of four chocolates each in a bottom layer... one job done - now and forever. I say it is a blessed thing to pack chocolates when one has been studying labor problems for some years. (29)

Under the laws of production, education becomes less socially significant than physical labor. Because academia cannot find a "solution" through the use of its theories, or finality in its endless quest for knowledge, education becomes a burden on a society

\footnotetext{
${ }^{5}$ Alternatively, Baudrillard and Thorstein Veblen both argue that production and labor are not natural desires in human beings. While Baudrillard privileges the human desire for "discharge, waste, sacrifice, prodigality, [and] play" (Mirror of Production 42), Veblen provides proof of such human nature through his definition of waste in The Theory of the Leisure Class (1899). Veblen argues that what workers desire most is to emulate the leisure class: "people will undergo a very considerable degree of privation in the comforts or the necessaries of life in order to afford what is considered a decent amount of wasteful consumption" (168). That is, workers desire the means to become non-productive.
} 
reliant on productive discourse, where everything has a meaning, a classification, and an end to the workday. Imagine the danger in imposing this ideology upon a woman who has not always had the right to education - to tell her that her productive labor is more important to society than her education. To understand Parker's full implication is to establish a society in which there is no mobility, no desire for higher achievement, but only work as its own end. But surely this ideology rests at the level of propaganda: Parker doesn't really believe her own argument, or else she would have given up her education in order to package chocolates.

Parker also asserts that a person's social value and her exercise of virtue should be measured by the relationship established between the laborer and her employer.

Consequently, other social relations in Parker's narrative become devoid of reciprocity in favor of the worker/employer relationship. Parker illustrates this argument through the relationship she establishes with her fellow factory worker Tessie. Although Parker asserts, "I do love Tessie, and I know that Tessie loves me," we begin to see that her love of Tessie, a love that supposes an attempt to empower Tessie (and those like her) by proving her social worth, ultimately functions to disempower Tessie in favor of a productive morality (22). Parker writes:

Tessie is nearest to me in the whole factory, and Tessie is slow. The faster I pack, the more it shows up Tessie's slowness. If Ida scolded Tessie it would break my heart. The thought of the man who owns the factory and his orders and his profits and his obligations, never enter my or the other packer's head. I will not pack so many boxes that Tessie gets left behind. Then a strange thing happens. All of a sudden I get more interested in packing chocolates than anything else on earth. A little knack or twist comes to me-my fingers fly (for me). I forget Tessie. I forget the time. I forget my feet. How many boxes can I pack today? That is all I can think of. (23-24) 
Parker's assertion that she loves Tessie is undermined by her momentary thought of an enigmatic and absent employer. Parker, an educated woman, reasserts morality as defined by loyalty to one's employer rather than by loyalty to a coworker. Parker's "all of a sudden" or "unintentional" response undermines her conclusion, which argues the need for similar responsibility and loyalty from women workers. This quotation also reveals an attempt to assert a form of dominance over Tessie. Parker establishes herself as a better worker/producer than Tessie - and a more labor conscious one at that. Parker herself becomes the embodiment of the "perfect worker" in order to highlight the lack of perfection she sees in others. Thus the question of women and their experience becomes marginalized in favor of a productive morality. But perhaps Parker's definition of loyalty and her commitment to production are due to the fact that Parker is only a temporary worker, and, by her own account, "no aggressive feminist" (p. 16).

Charlotte Perkins Gilman, on the other hand, a self-proclaimed feminist, similarly seeks to define women's power and morality as a productive force. In Woman and Economics (1898), Gilman argues that women's economic dependence on men is an aberration. Women's labor, Gilman argues, has become the property of her husband and what a woman receives is not directly proportional to what she gives (or produces) in the home. Woman and Economics, however, like Working with the Working Woman, privileges the language of production above all other forms of social value. In so doing Gilman's text highlights the contradiction that arises in conflating the "women's movement" with that of "labor reform." An example of this contradiction is Gilman's inability to escape the language of productivity in defining what morality means to the 
Progressive Era and the women's movement. Gilman explains that virtue is a relative term that changes in meaning throughout history. In the Progressive Era, virtue is defined as loyalty:

The unerring response of the soul to social needs has given us a new kind of loyalty, -- loyalty to our work... professional honor, duty to one's employers, duty to work itself at any cost, - this is loyalty, faithfulness, the power to stay put in relation to the social good, though it may be directly against personal interest. (137)

There appears here a strong contradiction posed between her main premise, her dedication to women's interests, and her definition of loyalty. The problem begins with requesting that women should "stay put," which assumes that women have no social demands other than the right to work. Gilman seeks to liberate women from their roles as wives and mothers only to subjugate them again before the laws of production - "work itself at any cost!’ But, as I have been arguing, these values are neither specific to nor in the best interests of women. ${ }^{6}$

Although Gilman provides adequate reasons for women's need to gain social and economic independence, she does not question the role of production in the creation of women as "dependent" creatures. Gilman states, "So inordinate is the sex distinction of

\footnotetext{
${ }^{6}$ In The Mirror of Production Baudrillard explains that, "the revolt of women aims at the code that makes the feminine an unmarked term. The youth revolt aims at the extremity of a process of racist discrimination in which it has no right to speak. The same holds for all those social groups that fall under the structural bar of repression, of regulation to a place where they lose their meaning. This position of revolt is no longer that of the economically exploited; it aims less at the extortion of surplus value than at the imposition of the code, which inscribes the present strategy of social domination" (134135). Baudrillard argues that women and children have no voice and no responsibility under a strict productive society. They do not count. Therefore, Baudrillard argues, those who are defined as "unmarked" oppose not inequality within the system but rather the system itself.
} 
the human race that the whole field of human progress has been considered a masculine prerogative" (27). Yet what Gilman acknowledges as the superior system has in fact been defined and created by men. That is, only before the laws of production are women "the sex" or even "the weaker sex." To uphold the laws of production will always support the claim that production is the only form of liberation and power. Nothing has, in essence, changed about the male-driven and -defined system. Gilman merely seeks to squeeze women into the production model of social value. Be it housework or factory work, women are still defined by their labor, yet that very model establishes women as the "second sex" in the first place.

Feminist Gilman gives credence to the sexist belief that production is what determines human status when she posits:

In the growth of industry, commerce, science, manufacture, government, art and religion, the male of our species has become human, far more than male. Strong as his passion is in him, inordinate as his indulgence, he is a far more normal animal than the female of his species - far less oversexed. (22)

Rather than challenge or deconstruct the notion that men are "more normal," "human," and "less oversexed" than women based on the assumption of man's productive power, Gilman concedes that the cause of women's dependence is that they are less human according to the laws of productive morality. But even Gilman's contention that women could become equal to men in the productive realm does not translate to equality between the sexes. That is, men will continue to have access to the higher paying jobs and receive the greater rewards as long as women have no power outside of the labor movement since men have set the terms of what constitutes success within the system. Consequently, an 
alternative form of gaining access to social worth and empowerment would need to be established. Yet under the discourse of production, there is no room to consider such alternatives. Rather than seek to break down the laws of production, Gilman exalts the system:

Economic production is the natural expression of human energy - not sex energy at all, but race energy - the unconscious functioning of the social organism.... The creative impulse, the desire to make, to express inner through outer form, "just for the work's sake, no use at all, I the work!"This is the distinguishing factor of humanity. (58)

In identifying work as the distinguishing factor of humanity, Gilman concedes that without work, "no social service is possible." Thus, Gilman is guilty of subjugating women before the laws of production. For the work force will inevitably view women who, for whatever reason, do not produce as lacking social value.

Gilman sees but two options for women to gain social wealth, that of the laborsystem or that of the sex-system, concluding that the latter system impedes social progress. Gilman writes, "The economic status of the human female is relative to the sexrelation" (3). That is, women have, in the past, only gained status from marriage or in direct relation to men who produce; women, by contrast, consume. Gilman asserts that women have remained entirely dependent and excluded from the public sphere to the extent that their humanity is questionable:

So utterly has the status of women been accepted as a sexual one that it has remained for the women's movement of the nineteenth century to devote much contention to the claim that women are persons! That women are persons as well as females - an unheard of proposition! (25)

A system that claims women are not persons based on their absence from the work force seems an absurd proposition. Why would a feminist movement seek to establish power 
within a system that relies on productive forces to beget a truly "human" being-- a system of production established on the premise of domination over others - rather than tear down such oppressive power structures?

Even more troubling than Gilman's argument for women's human status in terms of the very discourse that excludes them, is the way she defines the "sexuo-economic" relation between women and men as similar to the economic relationship that a man establishes with a prostitute:

The virtuous woman stands in close rank with her sisters, refusing to part with herself - her only economic goods - until she is assured of legal marriage, with its lifelong guarantee of support... But here enters the vicious woman, and offers the same goods - though of inferior quality, to be sure - for a far less price. Every one of such illegitimate competitors lowers the chances of the unmarried woman and the income of the married. No wonder those who hold themselves highly should be moved to bitterness at being undersold in this way. (55)

The only thing that stands between a woman who marries and a prostitute is a question of "virtue," implied here as chastity. Gilman's point was a strong one: that in remaining dependent on men for economic status, married women become no better than prostitutes. But the emphasis on prostitutes becomes interesting in relation to Gilman's progressive definition of virtue as "loyalty to one's employer" and "duty to work at any cost." By the nature of this new definition, prostitutes, too, become virtuous women ... albeit unintentionally.

Social reformers such as Gilman and Parker were not without their critics in their day. ${ }^{7}$ In an essay entitled "Intellectual Proletarians" (1914), anarchist Emma Goldman

\footnotetext{
${ }^{7}$ Gilman is also criticized today, though more often for her eugenicist beliefs than for the heart of her economic argument. For a contemporary critique of Gilman and eugenics,
} 
sought to close the gap between the women workers and the intellectuals who claimed to represent them. Goldman asserted that the "emancipated woman" is not as free as she claims herself to be. One can almost imagine Goldman speaking to Parker and Gilman as she writes:

The emancipated woman runs away from a stifling home atmosphere, only to rush from employment bureau to the literary broker and back again. She points with moral disgust to the girl of the redlight district, and is not aware that she too must sing, dance, write, or play and otherwise sell herself a thousand times in return for her living. Indeed the only difference between the working girl and the intellectual female or male proletarian is a matter of four hours. (180)

To sell oneself a thousand times implies that woman intellectuals are bound by political policies and public opinions to write not about what they think and see but rather in support of those ideologies that will actually sell. ${ }^{8}$ So while Gilman associates married women with prostitution, Goldman would argue that women like Gilman are even less removed from the redlight district than married women. In Goldman's view, women

see Alys Eve Winbaum's "Writing Feminist Genealogy: Charlotte Perkins Gilman, Racial Nationalism, and the Reproduction of Maternalist Feminism."

${ }^{8}$ We see examples of the economic dependence on social opinion clearly outlined in Gilman, who argues very strongly that women have been "over-sexed," that "our distinctions of sex are carried to such a degree as to be disadvantageous to our progress as individuals and as a race" (17). Though later Gilman, in an effort to placate possible critics, announces "So the 'new woman' will be no less female than the 'old woman,' though she has more functions... she will be with it all, more feminine, in that she will develop far more efficient process for caring for the young of the human race" (79). Gilman also seeks to reinforce the status quo in her quotation, "there is no fear to be wasted on the danger of women's choosing wrong professions. When they are free to choose, many women would continue to prefer the very kinds of work that they are doing now" (121). In establishing the fact that women's desire to leave the home will result in doing housework for others, Gilman does little more than change women's place of employment. 
intellectuals have little to offer to a society by upholding the status quo. Women writers would do better to break with the ideology of production; rather than instructing working women, they need to be instructed by them.

Goldman's critique of women labor reformers is similar to the critique that Baudrillard makes of Marx in The Mirror of Production (1975). For Goldman, the desperate need to insist on labor and production as the determinative value only implicates the intellectual, who believes herself to be acting as representative of labor, in that same structure. Thus the social reformer who seeks to represent the "proletariat" or "working woman" is likewise a "proletariat" bound to the sale of her labor efforts. For Baudrillard, Marx, in privileging the notion of production, imposed the concept of labor as a worker's primary means of self-comprehension-establishing the concept of production as the only way in which to view social worth. Marx, Gilman, and Parker offered no critique of the productive society that they were investigating. Thus, their advocating for social change and reform offered no real alternative; they merely upheld a productive system that was already in place.

At issue becomes how to challenge the power and social value of the labor system without instantiating another system of power to take its place. In Seduction, Baudrillard offers a new paradigm, shifting away from Marxist thought, and establishes seduction as the ability to overturn the masculine power of production (see my discussion of seduction in chapter one, pp. 11-23 and 33-34 in particular). In order to function as reality, masculinity needs constant affirmation of its "truth," a "truth" progressive era feminists are all too willing to grant. Baudrillard defines seduction as illusion, artifice, gambling, 
one-upmanship, secrecy, surface, ritual, and weakness. And nowhere does seduction

assert truth. Everything from cosmetics to animals, from cards to actresses, falls under the theory of seduction. What these concepts all have in common is their ability to disrupt the articulation of both meaning and value. They do not carry meaning - and they indicate no reality. Meaning is imposed upon them by productive discourse, and the meaning that is imposed exposes the inherent weakness of meaning-making systems.

Baudrillard attributes seduction to femininity because the very notion of the feminine carries no meaning. That is, femininity is an illusion in which production will always be thwarted; the masculine system of production continually seeks to interpret and give meaning to femininity. ${ }^{9}$ Of the seductress, Baudrillard argues, "she turns herself into a pure appearance, an artificial construct with which to capture the desires of others" (86). Feminism and gender studies have, for years, claimed that femininity is a social construct, but Baudrillard recognizes artifice as that which overturns all powers of production, desire, and sexuality (with which seduction should never be confused). ${ }^{10}$

${ }^{9}$ Feminists have long argued that femininity is an illusion. In "Womanliness as A Masquerade" (1929) Joan Rivière states, "The reader may ask how I define womanliness or where I draw the line between genuine womanliness and the masquerade. My suggestion is not however that there is any such difference; whether radical or superficial, they are the same thing" (306). Rivière's assertion was reinforced in 1991 when Louise J. Kaplan affirmed, "There is never a clear distinction between so called womanliness and a perverse masquerade of womanliness" (280). Simone de Beauvoir also accounts for this illusion when she argues, "If man fails to discover the secret essence of femininity, it is simply because it does not exist. Kept on the fringe of the world, woman cannot be objectively defined through this world, and her mystery conceals nothing but emptiness" (259).

${ }^{10}$ This argument was made as early as 1949 when Simone de Beauvoir wrote, "one is not born but rather becomes, a woman" and continues in the work of postmodern feminists and gender theorists such as Sandra Bartkey ("Foucault, Femininity and the 
While Charlotte Perkins Gilman acknowledges such a power in Woman and

Economics, she quickly dismisses it and banishes it before the laws of production.

Gilman states,

Parasitic creatures, whose living is obtained through the exertions of others develop powers of absorption and tenacity - the powers by which they profit most...Needless to say these faculties were those of sexattraction, the one power that has made [the man] cheerfully maintain, in what luxury he could, the being in whom he delighted. (32)

What Gilman describes as sex attraction has little to do with actual sex. It is the ability of women to become the veiled mirror of man's desire, and thereby escape the world of production. Although Gilman calls this power "parasitic," she actually concedes that women possess the ability to overturn the productive power that Gilman so heartily advocates. Thus the pejorative meaning of the word "parasitic" comes from privileging production. ${ }^{11}$

No doubt because of the time period in which it was written, many scholars are eager to read Edith Wharton's The House of Mirth (1905) as advocating the productive power of labor, upheld by women reformers such as Parker and Gilman, and reinforce

Modernization of Patriarchal Power"), Marilyn Frye (The Politics of Reality: Essays in Feminist Theory) and Judith Butler (Gender Trouble, Undoing Gender) (267).

${ }^{11}$ In The House of Mirth, Edith Wharton envisions the social parasite not as one who overturns productive forces, but one who feeds on the pleasure of society without creating any such pleasure of their own. Of the character Gerty Farish, the narrator writes, " it must be remembered that Gerty had always been a parasite of the moral order, living on the crumbs of other tables and content to look through the window at the banquet spread before her friends" (161). The fact that the narrator desires the reader to remember always that Gerty is the social parasite suggests that no other characters would fit the definition. Thus, the character Lily should never be read as parasitic - though she would be defined as such according to Gilman's definition of the term. 
Lily's role as one of those parasitic creatures that Gilman disdains. ${ }^{12}$ For example, Jennie Kassanoff argues, "Wharton indicates that Lily's status as a twenty-nine-year-old unmarried socialite renders her vulnerable to the whims of what Charlotte Perkins Gilman called 'the sexuo-economic relation"” (61). As such, most readings represent Lily Bart's story as one of negation, failure, and tragedy. ${ }^{13}$ Wai-Chee Dimock argues,

The power of the marketplace... resides not in its presence, which is only marginal in The House of Mirth, but in its ability to assimilate everything else into its domain. As a controlling logic, a mode of human conduct and human association, the marketplace is everywhere and nowhere, ubiquitous and invisible. (783)

Dimock argues that, even in its virtual invisibility, the power of the marketplace controls the behavior of, and is the impetus behind, character relations in The House of Mirth. ${ }^{14}$

But the fact that labor and the social value of the marketplace are not central to the story, that they play a marginal role, is precisely the point. In a society that privileges production as supreme, does not its marginalization in popular fiction become conspicuous? While Dimock's reading defines Lily as a rebel, though "not much of a rebel... For Lily's rebellion in its very feebleness and limitation, attests to the frightening power of the marketplace" (783), I read Wharton's novel and Lily as an acknowledgement of the frailty and limitations of the marketplace (783). Outside the

\footnotetext{
${ }^{12}$ See Elizabeth Ammons' Edith Wharton's Argument with America.

${ }^{13}$ In one recent example, Amy L. Blair argues that The House of Mirth "instructs young social climbers what situations they should avoid ... at all costs" by making Lily Bart "the sacrificial lamb" (150).

${ }^{14}$ More recent scholarship continues to espouse variations on Dimock's earlier argument. For example, in "Edith Wharton and the Fiction of Marital Unity" Laura K Johnson argues, "The House of Mirth chronicles Lily's unsuccessful efforts to locate a spiritual union that transcends the concerns of the marketplace" (952).
} 
mode of production, and acting as seductress, Lily is able to frustrate productive power with a mere turn of the head.

An example of the way in which Lily overturns the "power" of the marketplace through seduction occurs in the scene in which Gus Trenor offers to invest money for her in the stock market. While Lily and Gus are riding home from the train station, Lily tells Gus that she fears she has angered his wife Judy by failing to attain the marriage proposal of the millionaire Percy Gryce. Lily appeals to Gus on a level that never directly mentions her desire for his monetary assistance. She only appeals to his sympathy to make things right between her and Judy. The narrator states,

If his wife had consulted him on the subject of Miss Bart's future, he would have said that a girl with extravagant taste and no money had better marry the first rich man she could get; but with the subject of discussion at his side, turning to him for sympathy, making him feel that he understood her better than her dearest friends ... he was ready to swear that such a marriage was a desecration. (87-88)

A mere plea of sympathy and an appreciation for his unique ability to understand her in a moment of personal crisis turns Gus into a pawn of Lily's seductive game. He offers to invest money on her behalf so that she will not need to marry Percy. Gus, who would swear to his wife that Lily should be married off, is easily made to see that this marriage is not in Lily's best interest and thus he instates himself as her protector. The return on this investment is lucrative. Lily makes nine thousand dollars and risks not a penny of her own money. She is thus able to profit from marketplace values without work.

The bleak world of production is overshadowed by the presence of two great mechanisms of seduction in the novel, gambling and the theatre. Of games and gambling Baudrillard writes, "here lies the 'immorality' of games, often attributed to the fact that 
they encourage one to want to win too much too quickly. But this is to give them too much credit. Games are more immoral than that. They are immoral because they substitute an order of seduction for an order of production" (144). That is, games and gambling are stakes and challenges that do not rely on exchange value or use value. Gambling exists as a way to transgress the reciprocal laws of hard work and payment. Gambling is but a parody of such exchange. In the beginning of The House of Mirth we become aware of the fact that Lily is an avid gambler. Indeed her life is one of gambling against odds, thwarting the production paradigm at every turn. Lily says to her friend Gerty:

You think that we live on the rich, rather than with them: and so we do, in a sense- but it's a privilege we have to pay for! We eat their dinners, drink their wine, and smoke their cigarettes, and use their carriages and their opera-boxes and their private cars - yes, but there's a tax to pay on every one of those luxuries... the girl pays it by tips and cards too - oh, yes, I've had to take up bridge again - and by going to the best dress makers, and having just the right dress for every occasion. (279-280)

One wonders if Gerty is really supposed to be sorry for Lily at this moment. Her "payment" is so little in comparison to her material rewards. And if the knowledge that Lily's aunt gladly pays for all of her dresses, then supposes the act of gambling is Lily's only debt. Even this "tax" becomes suspect. The reader knows that Lily is addicted: "the increasing exhilaration of the game drove her to risk higher stakes at each fresh venture" (28).

Indeed Lily's life is dedicated to the game of stakes, a game that becomes dependent on artifice and appearance. What we mistake for Lily's desire-namely 
marriage - is never actually made explicit. ${ }^{15}$ Lily's "desire" to marry Percy Gryce, for example, is never her goal, contrary to even her own belief. That is, the act of being "une jeune fille á marier" allows Lily the ability to negotiate society. One such example emerges when Lily desires to skip a night of gambling after a night of excessive loss at cards. Lily is able to use the public knowledge of her quest to marry Percy in order to avoid bridge. Appealing to Judy Trenor for help - "if you are really interested in my career, perhaps you'll be kind enough not to ask me to play bridge again this evening"Lily is easily able to escape the "taxes" that she claims to have to pay (47). She even procures a dress from Judy as a gift to aid her in her quest.

In failing to address Lily's penchant for high stakes and high rewards, we misread and misunderstand her tactics. Percy Gryce is not a high enough stake to be of much interest to Lily. Thus we can trace Lily's waning interest in Gryce to her realization of a riskier venture. On the night of the party at the Dorsets', Lily takes a quick survey of the dinner table: "And Lily was therefore able to observe Bertha Dorset also and by carrying her glance a few feet further to set up a rapid comparison between Lawrence Selden and Mr. Gryce. It was that comparison which was her undoing. Why else had she suddenly grown so interested in Selden?" (56) The knowledge that Selden and Bertha are having an extramarital affair makes Selden interesting to Lily. He poses a greater challenge. Thus her desire for marriage is exposed as a ruse. Or, as the narrator later asserts, “competition really put her on her mettle" (63). Not marriage but game playing is Lily's

\footnotetext{
${ }^{15}$ In "The House of Mirth: Readers Respond" Deborah Lambert asserts that, in its reception to The House of Mirth, the Literary Digest "was critical of Lily's compromises and her failure to marry," which suggests that most readers, then as now, understand marriage as Lily's ultimate desire (71).
} 
"vocation." When Bertha retaliates against Lily by driving Percy away, she has essentially achieved nothing of consequence. Percy was never what Lily desired.

The novel's emphasis on theatricality and its focus on the actress also function to thwart the power of production. ${ }^{16}$ At the Van Osberg wedding, while gazing upon the bride, Lily notices the presence of a cinema crew hired to film the event, and we learn her desire: "The agent of a cinematograph syndicate was setting up his apparatus at the church door. It was the kind of scene in which Lily had often pictured herself as taking the principal part" (91). Critics often mistake Lily's dream to "play the principle part" as her desire for marriage. But the emphasis on the cinematograph syndicate indicates that Lily yearns for the life of an actress, the principle part in front of a camera. Baudrillard acknowledges the rise of the actress as the greatest seductive mechanism: "Undoubtedly the best example of... collective seduction produced by modern times [was] that of the film stars or cinema idols" (94). He also notes that the biggest stars were "endowed with the power of absolute absorption equal to and rivaling the real world's power of production" (95). The power of the film star was her artificiality. What fascinates the productive world is the absence of meaning behind the smile and gaze of the actress.

Lily is able to make her desires for stardom manifest at the home of the WellyBry's during the tableaux vivant. Her seductive powers take flight here and create the exact effect that Lily desires. Lily asserts after the tableaux that "the completeness of her

\footnotetext{
${ }^{16}$ In "Lily Bart and The Drama of Femininity," Cynthia Griffin Wolff explores the importance of theatricality in Wharton's novel, and mentions that "the early 1900s theater was one of the few arenas in which women exercised some real (if limited) power" (73). But Griffin fails to acknowledge the radical implications of her argument because she does not read Lily as an actress; she argues that Lily is representative of typical female characters within the early $20^{\text {th }}$ century play.
} 
triumph gave her an intoxicating sense of recovered power" (143). Indeed, she has seduced everyone in the room. After the tableaux those nearest to Lily fall prey to her trap. After her appearance on stage, Gerty says to Selden, “wasn’t she too beautiful Lawrence? Don't you like her best in that simple dress? It makes her look like the real Lily - the Lily I know," to which Selden replies, "the Lily we know" (142-143). The fact that Gerty and Selden recognize Lily's most artificial form as "the real Lily" testifies to the powers of seduction. For in this moment, Lily is not "the real Lily" at all, she is playing the part of Mrs. Lloyd in a painting by Reynolds. Thus, Lily becomes the mirror of Gerty and Selden's desires, effectively disrupting the productive corollary between appearing and being. Indeed, seduction is the result of playing at being, as Selden later unwittingly points out in his plea for Lily, "be good to her, Gerty, won't you?" and "She has it in her to become whatever she is believed to be" (165). What seduces both Gerty and Selden is not who Lily is, but rather what they can imagine about her.

Only much later does Gerty realize her mistake and understand the fools that seduction makes of them all. When Gerty has been left alone in her apartment, after arriving at the realization that Selden will never love her, she recognizes the one he does desire (Lily) as artificial:

Gerty felt the poverty, the insignificance of her surroundings; she beheld her life as it must appear to Lily. And the cruelty of Lily's judgments smote upon her memory. She saw that she had dressed her idol with attributes of her own making. When had Lily ever felt, or pitied, or understood? All she wanted was the taste of new experiences; she seemed like some cruel creature experimenting in a laboratory. (171) 
It is true that seduction can be cruel ${ }^{17}$ and even truer that Lily is the embodiment of cruelty. For who but Lily would, on arriving at her aunt's funeral, posit her only reflection as, "wondering vaguely where Gwen Stepney had got such an awful hat" (232). Yet exposing such cruelty does not diminish Lily's power. For Gerty still desires to fly to her friend's rescue whenever she is in trouble. Indeed Gerty offers up her own home to Lily and attempts to make Lily into what she believes Lily capable of becoming, a woman of morals and feeling for those less fortunate than herself. Gerty even goes so far as to help Lily attract the attention of Selden, the man Gerty desires for herself.

Soon after the tableaux vivants, Lily achieves her greatest success. In Nice, Carry

Fisher tells Selden that Lily has finally found her niche:

Lily has been a tremendous success here... She looks ten years younger I never saw her look so handsome. Lady Skiddaw took her everywhere in Cannes, and the Crown Princess of Macedonia had her stop for a week at Cimiez. People say that was the reason Bertha whisked the yacht off to Sicily: The Crown Princess didn't take much notice of her, and she couldn't bear to look on at Lily's triumph. (194-195)

The proximity of the tableaux vivant scene to Lily's success with the crowned heads of Europe is significant. During the tableaux Lily realizes the extent of her powers to seduce. She makes use of these powers in Europe, where she attracts the attention of royalty without possessing a penny, while those who, like Bertha Dorset, can monetarily

\footnotetext{
${ }^{17}$ Although seduction is cruel it is never accomplished by force. Baudrillard argues, "to produce is to materialize by force what belongs to another order, that of the secret and of seduction. Seduction is at all times and all places opposed to production" (34). Lily's cruelty is never instituted by force. It is only her appearance as illusion that is cruel because it refuses to play by the rules of productive forces. But the fact that seduction lacks force explains why Lily would never use Bertha's letters to incriminate Bertha and Selden, even if it would help to assuage her situation. To use the letters would be an institution of force and domination. Lily exists as seduction. So what some critics have ascribed as Lily's "morality" is only the refusal to resort to productive measures.
} 
afford to entertain such royalty go completely unnoticed. Sailing on the Dorsets' yacht, Lily has traveled the world in luxury on seduction's expense account. All that was required of Lily to ascertain this dream vacation (which arrived just in time to save her from marrying the horrible Mr. Rosedale - as if this were ever a real threat) was to distract Bertha Dorset's husband George. She merely had to act amusing.

Of course, Lily's game of challenges and stakes does not come without losses. But it is crucial to remember that Lily never fully realizes she has lost in the way that the reader supposes; for even what we recognize as definitive losses are mitigated by Lily's power of seduction. ${ }^{18}$ When expelled from the Dorsets' yacht after Bertha accuses Lily of trying to seduce her husband George, the narrator informs us that "even at the actual moment of her break with the Dorsets [Lily] had not so keen a sense of its consequences, for the Duchess Beltshire, hearing of the catastrophe from Lord Hubert, had instantly offered her protection" (237). Even after the loss of her aunt's inheritance, Lily's material and social position does not much change; she finds other members of society to pay her way. When Lily has been tossed out of the society that we believe she holds dear (that of the Trenor and the Dorset group), Lily is able to take up a position at the Gormers' and is afforded a free trip to Alaska, "for almost at once she had felt the insidious charm of slipping back into a life where every material difficulty was smoothed away" (245). By

\footnotetext{
${ }^{18}$ Deborah Lambert writes, "critics in 1905, granting Wharton her place in the American pantheon, nevertheless wrote negative reviews attacking the novel's implicit morality. Illustrative of their moral posture, they identified Lily Bart as a frivolous belle and understood her failure to marry as the natural result of her flawed character... Lily's life, so their argument ran, must teach a lesson about living in the world of the rich; since Lily's life could hardly be seen as exemplary, her misfortunes must act as a warning" (6970).
} 
being and acting through sheer artifice, Lily adapts herself to every new situation, as long as it offers her a certain level of luxury and comfort.

Nevertheless, Lily's changing social situations have continually been read as tragic. For example, Francis L. Restuccia reads Lily as powerless in a patriarchal society: "Wharton's novel conveys the feminist social message that women bred to be frilly decorations run risks of various sorts of death" (226). Restuccia's reading is symptomatic of the privileging of production in historical materialist readings of the time period as well as in Wharton scholarship. ${ }^{19}$ Yet Wharton's own emphasis on seductive power breaks down the illusion of production's supremacy. Only when Lily is banished from high society does she feel no social worth and social value, and the very act of labor drives a nail in her coffin. Thus, production becomes what denies women a sense of social value, social wealth, self-worth, and power.

While some might argue that Lily's downfall occurs the moment Gus Trenor approaches Lily about repaying her debt, such a reading reinforces the ideology of production, or the belief that there are only two means for women to progress socially and monetarily: through sex or through labor. When Gus poses the argument, "the man who pays for the dinner is generally allowed to have a seat at the table" (153), the reader understands his metaphor to mean that Gus expects sexual favors. But Lily, as seductress,

${ }^{19}$ In "Is Feminism a Historicism?" Jennifer L. Fleissner argues that within early 20th century American scholarship, "historicism's investment in 'locating' texts in a historical past risks turning both the literary texts it reads and its own critical predecessors into fossils to be examined and labeled, rather than voices that might in anyway speak backindeed, might speak back to the very procedures used to make sense of them" (48) More specifically, focusing on historicism often elides the radical nature of feminist reading practices. 
never acknowledges the truth behind the metaphor, as made evident by her repetition of the words "I don't know what you mean" (153). For Lily to win out over Gus in this moment she must repeatedly deny him access to the meaning of his words (that which makes Gus powerful). To acknowledge Gus's reference to sex would be to enter into the realm of the productive. Ultimately it is her refusal to engage in meaning making that protects her. While at one point Gus touches Lily in a way that she finds threatening, she remains physically unscathed going so far as to point out that "the words were worse than the touch" (155). The words that ultimately free Lily from Gus's grasp are, "I am here alone with you," and "What more do you have to say to me" (155). Lily relocates Gus's expectations, at once making his words, rather than his possible actions, threatening and diffusing the threat by failing to give credence to his words. This ultimately functions to break Gus: "To her surprise, Trenor answered the look with a speechless stare. With his last gust of words the flame had died out, leaving him chill and humble" (155). Gus's silence, indeed his powerlessness, is a direct result of Lily's employment of seduction.

Baudrillard explains that "what destroys people, wears them down, is the meaning that they give to their acts. But the seductress does not attach any meaning to what she does nor suffers the weight of desire" (87). With this in mind, we can track Lily's downfall to a very different moment in the novel. Before the scene in which Selden arrives at Mrs. Hatch's Emporium Hotel suite, Lily expresses happiness: "For a moment she found a certain amusement in the show, and in her own share of it: the situation had an ease and unconventionality distinctly refreshing after her experience of the irony of conventions" (290). However, life with Mrs. Hatch seemed "too soft" for Lily, and the 
appearance of Lawrence Selden drives Lily finally, and for the first time in the novel, to break down appearances and allow doubt to enter her mind (306): "Her momentary flashes of amusement were followed by increasing periods of doubt. The sense of these doubts were uppermost when late one afternoon, she was surprised by a visit from Lawrence Selden" (291). The change in Lily's position is marked by an increasing sense of doubt, driven by the arrival of Selden and his insistence on her position with Mrs. Hatch as "false." Lily interprets Selden's use of the word "false" as being "outside of what we call society" (295). In this tragic moment, Lily discovers that she is no longer in a position of power: "She had been on alert for the note of personal sympathy, for any sign of recovered power over him; and his attitude of sober impartiality, the absence of all response to her appeal, turned her hurt pride to blind resentment of his interference" (295). Lily's power, her ability to seduce, has been extinguished by a momentary feeling of doubt, a marked shift from her earlier statement that "she was always scrupulous about keeping up appearances to herself" (85). This moment forces Lily into the "real" 20 world, after which production and death soon follow.

On the very next page a jarring and sudden switch occurs in the tone of the novel.

\footnotetext{
${ }^{20}$ Lily admits that it is ultimately her moment of addressing the reality of her situation that drives her desire to pay Trenor back. Although she had spoken of her debt before, she never fully intended to re-pay him until the moment she allowed herself to give meaning to her actions. While working in the hat shop Lily admits that, "what really frightened her [was] the thought that she might gradually accommodate herself to remaining indefinitely in Trenor's debt as she had accommodated herself to the part allotted to her on the Sabrina, and as she had so nearly drifted into acquiescing with Stancy's scheme for Mrs. Hatch" (316). Lily's former ability to accommodate herself allowed for the necessary illusion to act without reflecting on meaning. It is "meaning" that destroys her.
} 
We find Lily working in a hat shop and the scene is bleak and more solemn than any scene preceding it. What Wharton describes in this scene is a weary mass of nameless, faceless, working women:

There were twenty of them in the work-room, their fagged profiles, under exaggerated hair, bowed in the harsh north light above the utensils of their art; for it was something more than an industry, surely, this creation of ever-varied settings for the face of fortunate womanhood. Their own faces were sallow with the unwholesomeness of hot air and sedentary toil, rather than with any actual signs of want ... the youngest among them was as dull and colorless as the middle-aged. (297)

The working women are described as weary and exhausted - their bowed heads, which not only hide their faces, also suggest a life that is powerless before the laws of production. The words "fortunate womanhood," a nod no doubt to the likes of Parker and Gilman, take on a bitter and ironic tone, as does Lily when she refers to the women as "liberated" (301). If these women enjoy life at all, it is only vicariously, through gossiping about the lives of the women who wear and enjoy the hats that they produce..$^{21}$ For Lily, the life of the working woman is no life at all.

But Lily's story is not a tragedy. Through Lily's death Wharton reinstates seduction as sovereign, emerging in two moments of the final scene. The first example appears in the scene where, on her deathbed, Lily lethargically switches from a dreamlike state into awakened consciousness and imagines she is holding Nettie Struther's child. Nettie has, prior to this scene, just informed Lily of the name of her child: "Marry

\footnotetext{
${ }^{21}$ This kind of vicarious enjoyment is portrayed in the novel as something that society desperately needs in order to survive in a productive world. When the working woman Nettie Struther is in conversation with Lily toward the end of the novel, she tells Lily, "Sometimes, when I felt real mean and got to wondering why things were so queerly fixed in the world, I used to remember that you were having a lovely time anyhow and that seemed to show that there was a kind of justice somewhere" (336).
} 
Anto'nette- that's what we call her: after the French queen in that play at the Garden- I told George the actress reminded me of you, and that made me fancy the name" (332). A child born under the sign of the actress and seduction is thus the final vision that Lily has before dying, and the presence of that child fills her with "a gentle penetrating thrill of warmth and pleasure" (340). The warmth and pleasure that Lily gains suggests that she takes comfort in the fact that seduction will still reign after her passing. For not only is Marry Anto'nette named after an actress in a play, but she is also given her name in tribute to Lily Bart. This end presupposes that the next generation will continue to battle the powers of production through seduction.

Secondly, and most importantly, is the effect of Lily and Selden's mention of the "word" that they must speak to each other, the word that will make everything understood. When Lily takes the final dose of the drug that will cause her death, the narrator asserts, "as she lay there she said to herself that there was something she must tell Selden, some word she had found that should make life clear between them" (341). Selden makes similar mention of a word that he must speak on his way to Lily's room: "He had found the word he meant to say to her, and it could not wait another moment to be said" (342). This word, for which no meaning or definition is provided, reinforces the pervasiveness of seduction, even when it appears that production has prevailed. The word seduces the reader. We, in turn, attempt to lend meaning to a word that essentially means nothing. Seductive power reigns in its very non-sense.

In 1926 Edith Wharton left her own clue to the reading I have provided here when she commented that the novel Gentlemen Prefer Blondes (1925) by Anita Loos was "the 
great American novel (at last!)" (xi). What Wharton calls the great American novel is a short comedic story of a young actress, Lorelei Lee, who, with her best friend Dorothy, travels the world and procures great wealth without ever earning her a penny, lending sexual favors, or having to suffer retribution for her power in the way of Lily Bart. It seems strange that Gentlemen Prefer Blondes, a novel whose style and tone could not be more different from Wharton's own writing, gained so much attention from her. But I would argue that Wharton praised Loos as a "genius" precisely because Lorelei never had to negotiate either the labor or the marriage market. As I argue in the next chapter, Lorelei negotiates a third option for achieving power. For Lorelei, every productive challenge met is a seductive challenge won, while the reader is too busy laughing to be threatened. The fact that Wharton so openly praised Loos in her use of seduction suggests that we have been misreading Lily Bart's social situation and social power, and have consequently missed the insight this character offers into Wharton's feminist political position. Moreover, the fact that, according to Wharton, "the great American novel" did not arrive until 1925, suggests that, by the modernist era, production ceased being the only means to women's social empowerment. 


\section{CHAPTER FOUR}

\section{SELF-SPECTACULARIZATION AND SEDUCTION:}

\section{DE-EMPHASIZING SEX AND SEXUALITY IN MODERNIST-ERA FEMINISM}

\section{AND FICTION}

\section{Producing Sex}

By now it seems a near cliché to address the fact that literary modernism and cultural modernity (1910s to 1930 s) were politically inactive periods in feminism. ${ }^{1}$ With suffrage won, the specific aims of feminism became unclear. As early as 1938, Virginia Woolf proclaimed with great irony that feminism was dead. Thirty years later Shulamith Firestone looks back upon the 20 s as an unfortunate event in the history of feminism. ${ }^{2}$ Today the best that we can imagine for women of the interwar period was that they had

\footnotetext{
${ }^{1}$ Contemporary scholarship continues to embrace the same narratives about feminism in the 1920s that Nancy Cott supported in the 1980s. For example, in "The New Era and New Woman: Lou Henry Hoover and 'Feminism's Awkward Age'" (2004), Kendrick A Clemets writes: "As Nancy Cott has observed, the argument being made by Lou Hoover and others in the 1920s was not really a feminist one. By contending that a new, public role for women was a reaction to changing historical circumstances, rather than a deliberate decision to conquer society's limitations, women like Hoover were asserting their right to work but not really challenging the 'gender hierarchy' of American society" (444).

2 In The Dialectic of Sex: The Case for a Feminist Revolution (1970), Firestone writes, 'Here in the twenties, is the beginning of that obsessive modern cultivation of 'style,' the search for glamour (you too can be Theda Bara), a cultural disease still dissipating women today - fanned by women's magazines of the Vogue, Glamour, Mademoiselle, Cosmopolitan variety. The search for a 'different' personal style with which to 'express' oneself replaced the old feminist emphasis on character development through responsibility and learning experience" (25).
} 
some kind of vague sexual prowess. ${ }^{3}$ Women after the war are generally conceived as superficial flappers more concerned with fashion, drinking, and jazz than with issues of equality. Writers like Kenneth Yellis and Lewis Erenberg discuss the "new woman" as threatening to traditional morality and as rebelling against older sexual mores. Yellis writes, "Women had now taken to swearing and smoking" and "using contraceptives," as if these actions are correlative signifiers (46). Women no longer show any collective desire for political power and authority. According to many narratives of the modernist era, the flapper's mother won the war on inequality, and her daughter enjoyed the benefits of the feminist struggle. The modern woman's public presence in the workplace, the public streets, the dance hall, and the cabaret are provided as historical evidence in support of the idea that the modern woman was content with her new publicly sanctioned liberty.

However, after the publication of Sexology Uncensored: The Documents of Sexual Science (1998), in which editors Laura Doan and Lucy Bland present a collection of sexual-reform essays by early twentieth century feminists such as Dora Russell, Marie Stopes, and Stella Brown, there has been a critical resurgence of work expressing dissatisfaction with narratives that support the notion of modern feminist political inactivity. These revisionist accounts of women in the modernist era focus on issues of

\footnotetext{
${ }^{3}$ In The Spectacular Modern Woman: Feminine Visibility in the 1920s (2004), Liz Conor writes of the flapper: "Everywhere she appeared she was marked by scandal because, by constituting herself as spectacle, she was asserting her sexual agency" (13).
} 
feminism and sexual reform. ${ }^{4}$ In "Rewriting Sex: Mina Loy, Marie Stopes, and Sexology" (2003) Paul Pepis argues, "At the moment this public debate on sex reaches a fevered pitch, World War I significantly reconfigures sexual and power relations between women and men" (562). Although Peppis concedes that the power women reformers wielded in terms of their engagement in heated debates regarding sex education, birth control, and the promotion of orgasm for women, were short lived, he does not consider that utilizing sex as a trope for feminist empowerment could itself explain the fact that any strides gained toward "sexual equality" (i.e. gender equality) in the short term did not last through the second World War.

In order to explain why women sexual reformers achieved short-lived power for women, it seems necessary to invoke Foucault on the commonly accepted link between sexual reform and women's liberation. For while Foucault argues that discourses on sex feed into current power structures, he offers no possibility of resistance to power. In short, "speaking out" about sex serves only the institutions that regulate sexual behavior. The radical potential for using sexual reform as a means of empowering women is always already contained by the medical and theoretical discourse that these sex reformers utilize in their writing and politics. In History of Sexuality Foucault writes: "the least glimmer of truth [about sex] is conditioned by politics. Hence, one cannot hope to obtain the desired

\footnotetext{
${ }^{4}$ See, for example, Ivan Crosier's “'All the World's a Stage': Dora Russell, Norman Haire, and the 1929 London World League for Sexual Reform Congress" (2003); Karen Chow's "Popular Sexual Knowledges and Women's Agency in 1920s England: Marie Stopes's 'Married Love' and E. M. Hull's 'The Sheik"” (1999); Jessamyn Neuhaus's “The Importance of Being Orgasmic: Sexuality, Gender, and Marital Sex Manuals in the United States, 1920-1963” (2000); and Stephen Brooke's “The Body and Socialism: Dora Russell in the 1920s" (2005).
} 
results simply from a medical practice, nor from theoretical discourse, however rigorously pursued" (5). In short, speaking in terms of sex cannot empower disenfranchised social groups. Sexual reform only adds to the discourse on sex, which then can be used to regulate social and sexual practices. It is not insignificant, for example, that in all of the discourse related to sexual reform the figure of the prostitute as embodiment of the amalgamation of sexuality and economics - is continually described as the greatest of all social evils. Nor is it insignificant that many of the feminists writing about female pleasure during this time period condone sex as a positive act only as it occurs within the sacred bonds of marriage. In short, the radical potential for using sex as a discourse of liberation is already closed off by the dictates of social responsibility, respectability, and traditional notions of femininity. The laws regarding discourse on sex, as Foucault argues, produce the imperative to both speak about and to regulate sex.

When Jean Baudrillard asked the editorial board of the French Literary Journal Critique to "Forget Foucault" in 1976, a strategic move that had negative effects on both his reputation and the size of his readership, he did so because he argued that Foucault's Will to Knowledge, the theoretical precursor to The History of Sexuality, essentially changed nothing about our ability to theorize sex and power. In Baudrillard's estimation, Foucault's move from theorizing power as oppressive to theorizing power as productive does not change the idea that power is the inevitable result of politics and discourse. Baudrillard writes, "Foucault can thus describe the successive spirals of power, the last of which enables him to mark its most minute terminations, although power never ceases 
being the term, and the question of its extinction can never arise" (FF 31). Whereas the discourse of sex was once conceived of as singular (repression), now sex-discourse is conceived of as multiple and web-like (production). ${ }^{5}$ If the end result of discourse about sex is always the production of power, then possibilities for challenging the law of sexuality cannot be theorized. Or as Baudrillard writes, "what difference does it make whether we say repression or an 'induced' mode of speaking? It is only a question of terminology" (FF 34). Moreover, power, in Foucault's theorization becomes minute, even more precise, and works its way into every facet of society. As such, how can feminists imagine change or reversion when power is always the final and inevitable result of all discourse about sex $?^{6}$ This is why Baudrillard argues that feminism, in theorizing about female sex and sexuality, inevitably replicates the power structures that are already in place. Sex as theorized by Baudrillard is productive masculine discourse and thus contains no possibility for reversion by nature of its very structure in society. In Seduction (1979), Baudrillard argues, "the danger of the sexual revolution for the female is that she will be enclosed within a structure that condemns her to either discrimination

\footnotetext{
${ }^{5}$ Baudrillard is similar to Foucault in his argument that repression never existed in society. However, Baudrillard's argument about repression does not carry Foucault's meaning. Where Foucault claims that there has not been repression but rather a compulsion to speak about sex, Baudrillard argues that the reason that there has never been any repression in society is because there "has never been any sexuality" (42, my italics).

${ }^{6}$ Baudrillard uses the word "reversion" because he argues that the word "subversion" should not be the aim of radical movements. Subversion points to brief moments of rebellion, implying a new power. The aim should be reversion because the logic that governs the laws of production is irreversible. That is, once an ideology has been established as truth, it becomes an irreversible logic. The aim of radical movements should be the reversion of irreversible ideology without the institution of another irreversible truth.
} 
within the structure when the structure is strong, or a derisory triumph within a weakened structure" (6). According to Baudrillard, sex and sexuality are governed by a productive structure, the dichotomy between subject and object, what I term the political backslash, which is not dissolved in arguing for a feminist sexual revolution. This dichotomy would need to be overturned before any revolution from the oppression of power dichotomies can be achieved. We need to challenge the authority and production of sexual discourse.

For Baudrillard, sexuality has been governed by the masculine production of sexual discourse created by Freud: the laws of the father, the phallus, and castration. Freud, like Marx, theorized society according to a binary of subject/object. The subject/object divide similarly structures economics and psychology. While Marx naturalized the binary subject/object through the concept of "need," Freud naturalized the subject/object divide through "desire," and both of these binaries depend upon ultimately oppressive ideologies. Although Freud theorized that society and the family structured who is on the desiring and who on the receiving end of sexual desire, he never questioned the subject/object dichotomy as natural. Because sexuality is always masculine according to Freud, even when women are engaging in it, any establishment of different terms for this structure, by arguing for a female sexuality, continues the essentialism of Freud, perpetuating his proposition of body as destiny. ${ }^{7}$

Power, according to Baudrillard, is an inevitable result of masculine productive

\footnotetext{
${ }^{7}$ In Freud on Women, Elizabeth Young Bruehl writes, "With this 1925 paper, Freud went even further in the direction of 'anatomy is destiny' than he had ever before. The girl's phallic phase is not just a period of realistic discovery followed by envy; it is a period of repression. And once again repression is the key to leaving behind bisexuality and assuming a feminine attitude" (38).
} 
discourses that form the basis for theories of both sex and labor. Productive discourses are those discourses that create the structure for our society: what we consider to be truth and reality. Productive discourses are, according to Baudrillard, irreversible ideologies from which all power emanates. That is, once the laws of production are established as truth, they are difficult to challenge. They can only be replaced by other productive ideologies, while the law of production remains fixed. So if, as Foucault suggests, society is structured by power through discourse on sex, how we conceive of sex may change historically, but sex as a truth, a reality, and as a way to construct society remains intact. In fact, the more we speak and write about sex, the stronger it becomes. This is why Baudrillard claims that Foucault did not change anything in theorizing about sex; on the contrary, Foucault actually strengthened the discourse on sex by showing the ways in which sex is regulated by power-discourse. The possibility for challenging the authority indeed, the very existence - of sex becomes impossible through each written and spoken word.

In Forget Foucault (1977), Baudrillard defines, once again, what he means by production, particularly as production relates to sex:

From one discourse to another - since it really is a question of discourse there runs the same ultimatum of pro-duction in the literal sense of the word. The original sense of 'production' is not in fact that of material manufacture; rather, it means to render visible, to cause to appear and be made to appear: pro-ducere [sic]. Sex is produced as one produces a document, or an actor is said to appear on stage. To produce is to force what belongs to another order (that of secrecy and seduction) to materialize. (37)

Productive discourse itself, according to Baudrillard, gives rise to sex and sexuality. Sex is not some thing that exists in the world which medical discourse describes, records, and 
observes in order to control and regulate society; rather, it is the method that comes first, the law and the technology of production from which this thing called sex follows. According to Baudrillard, we do not have a sex or sexuality - homosexuality, bisexuality, transsexuality, or a natural desire for certain sexual objects - so much as we have an ideology of production that requires the perpetuation of discourse on sex. A broader danger for feminism in the perpetuation of productive discourses emerges in the fact that these discourses are the basis for and the rationality behind oppression, colonization, inequality, and racism. The masculine production of sexuality and sex becomes the ground zero where all other races, genders, and cultures are judged. Baudrillard writes that "psychoanalysis came to clear the way for sex by telling what was hidden - how incredible is the racism of truth, the evangelical racism of psychoanalysis; everything changed with the coming of the Word" (Forget Foucault 42). The racism that Baudrillard refers to and tropes on is the racism of Western ideology. The knowledge produced by psychoanalysis in legitimizing and creating the laws of sex is used to explain other societies, genders, and cultures without accounting for the ways in which we impose the production of sexual discourse upon others. The fact that Baudrillard capitalizes the letter "w" in his discourse is suggestive: the production of discourse has become the colonizing religion of the West. To what extent, then, do feminists and sexual reformers propagate this discourse and the oppressive power structure at its core even while they seek to create sexual equality between men and women $?^{8}$ There must be a challenge to the

\footnotetext{
${ }^{8}$ Sex educator Margaret Sanger often uses contradictory examples of "primitive" cultures as evidence in support of her claims about the "natural" process of sex. I say contradictory because knowledge about primitive cultures is also used to decry aspects of
} 
pervasive reality of sexual discourse, and its ability to structure society, before any question of equality can be raised.

What follows is a critical engagement with feminist reformers of the 1910s through the 1930s who attempted to empower women through sex reform. It is my argument that any feminist revolution that invokes the discourse of sex, even or especially sex reform, ultimately ends up perpetuating oppressive masculine ideology. ${ }^{9}$ The social value of sex, especially the use of sexual discourse in explaining gendered phenomena, becomes more significant than the empowerment of women or the breakdown of the so-called sexual double standard. Sex education and sex reform can be seen, not as sources of empowerment for women, so much as regulation and naturalization of what is expected of women in their sexual relationships to the benefit of a masculine economy. My argument is not the common one that espouses the view that sex reformers upheld the status quo, which has been argued extensively, but an argument

sex deemed unnatural. While Sanger links the bonding of women's feet in China to the Western binding of the woman's pelvic area in order to underscore the fact that Western cultures are not culturally superior to that of the East (13), she later uses the sex habits of the aboriginal Australian, "the loWest known species of the human family," to argue the superior brain control of Euro-American men (47). Sanger lauds the "ancient Teutons" for the fact that they considered it shameful for young men to have sexual relations before their twenty-sixth year, as evidence of the fact that men should wait for marriage to engage in sex. She uses ritual passage rites of the Yuman Indians as evidence of the fact that sex education is both natural and necessary: "Savages have recognized the importance of plain sexual talks to their young for ages, while civilization is still hiding itself under the black veil of prudery" (24).

${ }^{9}$ In The Second Sex, Simone de Beauvoir underscores the oppressive nature of discourses on sexuality in her statement, "man is a human being with sexuality; woman is a complete individual, equal to the male, only if she too is a human being with sexuality" (682). 
against the fallacious link between sex discourse and feminism. ${ }^{10}$ What needs to be critiqued is "the truth" -- the cultural given -- of sex and feminism's role in the production of sexual logic.

\section{Sexual Reform in the Modernist Era}

In his article “"All the World's a Stage': Dora Russell, Norman Haire, and the 1929 London World League for Sexual Reform Congress" (2003), Ivan Crosier lists the ten planks that made up the central political platform of the World League for Sexual Reform. Included in these planks for reform were: "political, economic, and sexual equality of men and women," "control of conception, so that procreation may be undertaken only deliberately and with a due sense of responsibility," "prevention of prostitution and venereal disease" (28), and "systematic sexual education" (29). Also at issue for the sex reformers and educators was, as Jessamyn Neuhaus maintains in "The Importance of Being Orgasmic: Sexuality, Gender, and Marital Sex Manuals in the United States, 1920-1963" (2000), an effort “to correct faulty male sexual technique, with a view toward increasing female pleasure" $(450) .{ }^{11}$ Reading these reform aims through

\footnotetext{
${ }^{10}$ Specifically, I mean to challenge such arguments as Karen Chow makes in "Popular Sexual Knowledges and Women's agency in 1920s England: Marie Stopes's 'Married Love' and E.M. Hull's 'The Sheik." Chow argues that, "popular discourses of women's sexuality in 1920s England ... and sex manuals like Marie Stopes's Married Life ... despite their adherence to status quo values, were liberating for women through their affirmation of women's sexual subjectivity" (64).

${ }^{11}$ Neuhaus espouses the contemporary feminist critique of sexual reform in the 1920 s or the idea that women reformers upheld the status quo by admitting that men were the primary agents in sex and thus responsible for the sexual pleasure of women: "They relegated the 'awakening' of female sexual pleasure to the domain of male skill, leaving men firmly in charge of that pleasure ... these manuals made female orgasm central to 'successful intercourse"” (450). However, I would argue that Neuhaus's critique is not
} 
Baudrillard's theory on sex and sexuality is particularly helpful to my argument that sex reform was productively masculine in design and thus not entirely congruent with the critical or social aims of feminism. The efforts of sexual reform strengthen the ideology of sex by perpetuating certain cultural imperatives to the extent that they become instantiated as unilateral truth in society: at all times and places, female pleasure must be awakened, sex must happen responsibly, prostitution must be expelled from society, and men and women must be equal. The production of discourse about sex is larger than any revolutionary aim because the more sexual discourse is instantiated as truth the less likely the ideology of sex as a biological and cultural given is to be challenged. The questions, who benefits from the aims of sex reform and by whose standard is equality measured, become central to any critique of these reform efforts. We do not need to "better understand" women's sexuality so much as we need a challenge to the natural scientific discourse on sex - what has been used to explain a woman's sexual passivity, or, worse, her hysteria.

The modernist era ushers in a shift in women's writing. While Charlotte Perkins Gilman argues that "economic production is the natural expression of human energy" (58) in the progressive era, feminism of the modernist era is primarily concerned with the natural expression of sex. Although the shift from labor to sex is a marked difference, the effect is still the same because both discourses are governed by the laws of production. While Gilman argues in Women and Economics that production and labor are responsible

radical enough because it suggests that giving women power over their own sexual pleasure would be a viable alternative, when in fact such a proposition would mean a perpetuation of masculine discourse on the pleasure derived from sex - a substitution of one truth (male power) for another (female power) without critiquing the original. 
for the creative impulse, American sex educator and reformer Margaret Sanger argues, in her 1920's pamphlet "What Every Girl Should Know," that the creative impulse is governed by the sexual impulse. Sanger writes:

The sexual impulse is the strongest force in all living creatures. It is this that animates the struggle for existence ... it is this that also inspires man to all endeavors and achievements, to all art and poetry; this impulse is the creative instinct which dominates all living things and without which life must die. If then, this force, this impulse plays so strong a part in our lives, is it not necessary that we should know something about it? (35)

Thus the discourse of sex and the discourse of labor both affirm production as natural human expression. Sanger's romantic introduction to her sub-section entitled "the sexual impulse" articulates both the primacy of sex in the lives of men and links this impulse to noble pursuits. Linking sex to art has the effect of disassociating sex from base animal desires and relocates sex as the motivation behind the structures of society and culture. Sex becomes at once that which connects us to nature, as it dominates all living things, and that which enables us to control and manipulate nature, that which makes us noble and creative. Even though the sex impulse rules the lives of human beings, our ability to sublimate sex through our creation of art and poetry constitutes our humanity or our power over the base natural world. Sex knowledge, according to Sanger, is power, power over the ability to reproduce, which she then wants to impress upon young women of the working classes. Sanger's definition of the sexual impulse has its desired effect: it both valorizes sex as natural and preaches abstinence, or harnesses this impulse to the production of culture, knowledge, and social responsibility. Whether through the creation of art and poetry, the dissemination of sexual knowledge, or the reproduction of the species, sex is always a question of production, one that, before Sanger's day, had been 
the domain of scientific, artistic, and noble men. ${ }^{12}$

Because Sanger and other reformers argue that the function of sex is the reproduction of the species, they reinforce sex as the ultimate site of a woman's pleasure. However, within the emerging discourse on female sexual pleasure or orgasm, there is first the requirement that pleasure be experienced in a way that perpetuates the values of masculine society. The advent of the modernist era ushers in a whole set of belief systems that challenge orgasm as some base, fearful, brute, or animal passion and reinstate orgasm as both natural and desirable. In the creation of such a discourse, the primacy of the orgasm becomes larger than any other women's issue because the assumption is first that men have orgasms and that, because of this fact, women should orgasm too. ${ }^{13}$ Equality is measured by the fundamental truth of the male orgasm. In The Sex Side of Life: An Explanation for Young People (1919), Mary Ware Dennett, an American birth control activist and sex reformer, decries the lack of discussion of orgasm in books for young people. She attempts to correct this aberration by presenting the orgasm as "something which rightly belongs to every normal human being, a joy to be proudly and serenely experienced" (4). The orgasm is thus, according to Dennett, not only natural and

\footnotetext{
${ }^{12}$ I recognize that some feminists distinguish production from reproduction by claiming that the latter is women's realm, and the former men's. However, women's reproduction is governed and subsumed by the laws of production. Reproduction is desirable in so far as it functions in accordance with the social value of production.

${ }^{13}$ In "Sexologists Examine Lesbian and Prostitutes in the United States, 1840-1940" (2000), Heather Lee Miller writes, "In the nineteenth century, many white, middle- and upper-class Americans and Britons not only adhered to the ideal of female 'passionlessness,' believing that women had little or no desire of their own and what did exist could be aroused only by a man, but they also thought female same-sex behavior to be physically impossible ('true' sex necessitated a phallus)" (71).
} 
normal but also a human right. She argues that, prior to the cultural moment of her writing, there was "all too evident an inference that sex emotion is a thing to be ashamed of" (4). Dennett assumes that the production of positive discourse about the orgasm will correct the faulty representation or prohibition of sexual discourse in society. However, Dennett's own writing exposes the fact that, far from being a natural experience belonging to every normal human being, the orgasm is both historically and socially constructed, and in ways that benefit men. Dennett writes, "by the rhythmic movement of the penis in and out, the sex act reaches an exciting climax or orgasm, when there is for the woman a particularly satisfying contraction of the muscles of the passage and for the man, the expulsion of semen, the liquid which contains the germ of life" (9). Dennett suggests not only that the rhythm of penis is responsible for any pleasure achieved through the sex act, and that the stimulation of the vagina is the natural means to orgasm, but also that the sex act is consistently pleasurable for both men and women. Further reinforcing the primacy of the man's role in orgasm, Dennett endows the male with an active, moving, ejaculating penis, while the female's pleasure is described as a passive "passage" of contracting muscles.

While Dennett articulates a default vaginal female pleasure, reformers were not ignorant of other possibilities for sexual pleasure. However, other strategies for pleasure were generally constructed as negative within the discourse of sex reform. In "The Sex Factor in Marriage" (1930), British sex reformer, educator, and medical doctor Helena Rosa Wright states:

Theoretically it might be said that the ideal type of feminine sensation is concerned with the vagina alone, but that ideal is seldom realized. As a 
general rule it is true to say that a woman has not reached full sex maturity until she is able to feel pleasure as acutely in the vagina as in the region of the clitoris. (Sexology Uncensored 131)

This quotation provides an example of what Baudrillard means when he accuses feminism of coming too close to the order of the truth. Even though, as Wright suggests, clitoral stimulation is the more common means to female orgasm, quantitative evidence that could be used to challenge both the vagina as the primary site of sexual pleasure and the power of the penis, the "truth" becomes that which supports the production of social values. So, where data and evidence cannot support the desired conclusion, cultural norms must step in. Invoking a woman's "sexual maturity” allows Wright to reinforce the role of the penis in feminine pleasure. What becomes more important than the physical sensation of the body is what is socially acceptable, a "truth" that can only be articulated through a cultural notion of "sexual maturity" masked as scientific evidence. We can see this demand for a masculine induced female pleasure or orgasm constantly reinforced throughout the literature of sex manuals and sex reform, all of which draw from the "scientific" sexual discourse of Freud and Havelock Ellis who articulate sexual maturity in women as a convenient shift from clitoral to vaginal stimulation.

Even the more radical reformers who argued for sexual pleasure outside of marriage similarly use productive language by arguing that sex carries cultural weight and value. For example, in "Hypatia or Women and Knowledge" (1925), British author, feminist, and sexual reformer Dora Russell argues that "most males ... have tried to persuade women that their part in sex is pregnancy and childbirth" (Sexology Uncensored 124). Russell seeks to liberate women, encouraging them to have sex outside of marriage, 
by arguing that sex carries social value beyond childbirth. In her discussion of the

modern woman, Russell writes:

There is this that is new: that, though these younger women may be driven from fear of starvation to the outward acceptance of old codes and conventions, inwardly they know they have done no wrong and will not admit a conviction of $\sin$. Sex, even without children, and without marriage, is to them a thing of dignity, beauty, and delight. (Sexology Uncensored 124)

Sex is always a question of the production of value, even if only to reinforce sex as always pleasurable for women so as to keep heterosexuality alive. Within reformer discourse there is never a challenge to the ideology that heterosexual sex is fundamentally pleasurable for women, which proves that sex as a discourse is more important to the reformer than the actual lived experience of those who do not conform to the ideology of sex as socially valuable.

However, if sexual pleasure is articulated in any way that does not conform to the value of production and meaning, as in the case of masturbation, then it is quickly dismissed as unhealthy, unnatural, and wrong. Within the discourse of sex reformers, the concept of discharge and waste, that which cannot be either quantified or qualified according to the laws of production, is devalued - particularly in regard to both masturbation and prostitution. ${ }^{14}$ The importance of the discourse on masturbation in regard to sex reform cannot be overstated. In "Eugenics, Race and Margaret Sanger Revisited: Reproductive Freedom for all?”(2007), Alexander Sanger, Margaret's

\footnotetext{
${ }^{14}$ A notable difference to this generalization is offered by Mary Ware Dennett who argues, "for generations [masturbation] has been considered wrong and dangerous, but recently many of the best scientists have concluded that the chief harm has come from the worry caused by doing it, when one believed it to be wrong" (14).
} 
grandson, argues that, "the entry point for eugenics into political discourse came from societal disapproval of certain sexual activities, specifically masturbation" (211). I would argue that the reason masturbation met with such disapproval is because masturbation carries no social value according to the laws of production. Masturbation is, first and foremost, a waste of sexual energy with no greater social purpose than self-pleasure. Margaret Sanger writes of masturbation in adolescents:

It stands to reason that to abuse these organs before they are strong enough to be exercised must weaken them for their natural functions. Again, masturbation unlike the sexual act can be practiced individually, and at all times and nearly anywhere. This gives the individual unlimited opportunity for indulgence, and consequently drains and exhausts the system of the vitality necessary for full development. (38-39)

According to Sanger, the sex act is intended for a specific social purpose or goal. If that purpose is unclear, or if it does not add to the betterment of the society as a whole, then it is simply a matter of individual indulgence. Within the discourse of sex, the ideology of individualism quite literally drains the system (both the body and the body politic) of vitality. Masturbation, as an individual practice that can happen anywhere and anytime, cannot be recorded, documented, and studied in ways that support the production of social value. The inability to control the production of masturbation, to regulate when and where it should happen, is perhaps the greatest danger. Sanger argues that the desire for masturbation - or individual indulgence - is stronger in men than in women, but she also writes, "it is much more difficult for a girl to overcome the habit [of masturbation] than a man. The effects are more permanent in her" (40).

Although Sanger does not articulate why the habit of masturbation is more difficult for women to break than men, it suffices to say that the reason has to do with the 
fact that the clitoris, glaringly unaddressed, has no social value within productive sexual discourse. Although Margaret Sanger notes that a form of external sexual stimulation is possible for women, "caused by uncleanliness, itching, tight clothing, etc" (37), she does not name the clitoris, and she lumps this kind of stimulation in among the "danger and temptation" of masturbation (41). ${ }^{15}$ It is not insignificant that the clitoris is relegated to the realm of the etcetera, or the unspecified. Indeed, within the productive discourse of sex, the clitoris has no specified social function. The clitoris represents the remainder, the rest, the surplus, and the outside of sexual function. The vagina, on the other hand, the "natural" and productive cite for orgasm, has a specific productive purpose: pleasuring the man and bearing children.

On the other hand, masturbation in men is addressed with more specificity. It is more acceptable to explain masturbation as it occurs in boys due to the fact that the male uses the same organ to masturbate as he does to perform "natural" sex. To describe clitoral stimulation would be to encourage great danger. In her discussion of young women Sanger writes, "perhaps the greatest physical danger to the chronic masturbator is the inability to perform the sexual act naturally" (39). Ironically, the greatest physical danger is also the greatest social danger. A woman who experiences pleasure outside of the vagina is dangerous to the extent that she cannot confirm the primacy of the male sex organ in climax. Pleasure for women, then, is not exactly the aim of sexual reform so

\footnotetext{
${ }^{15}$ The fact that Sanger does not name the clitoris opens up the possibility for reading this section of her pamphlet through Baudrillard's theory of seduction, in that she both denies knowledge of, and refuses to supply representation to, the act in women. This possible reading, however, is staved off by nature of the negative value judgment that Sanger makes regarding women and masturbation in general. For Baudrillard, seduction is never a process of value.
} 
much as it is an aim to encourage both men and women to engage in sex productively, in ways that add value to the social ideology of love. For, as Margaret Sanger writes, the "sexual impulse," defined as the desire to touch, caress, write, and speak to members of the opposite sex combined with a desire to "discharge the accumulation of ripe cells," is what "constitutes the foundation upon which love, the greatest of all emotions, is based" $(35-36)$.

Perhaps an even greater concern for sexual reformers than masturbation is the pervasive threat of prostitution. Much of the literature on sex education includes efforts both to save women from becoming prostitutes, and to create an authoritative social discourse in which the prostitute is figured as threatening the values of institutions like marriage, public health, and the economy. Indeed, the entire impetus behind Margaret Sanger's "What Every Girl Should Know" is the belief that "ignorance about the sex function is one of the strongest forces that sends young girls into unclean living" (7). The prostitute is perhaps the most concentrated example of the problem of invoking productive ideology regarding women and liberation. Prostitutes figure into reformer discourse as the ultimate social disease. It is not insignificant, for example, that sex manuals link the increasing outbreak of venereal disease, gonorrhea, and syphilis to the prostitute, who is always the carrier, never the victim, of disease. (Sanger, a notable exception, will be discussed later). Mary Ware Dennett, in her sexual explanation for young people, writes, "men often get these dreadful diseases by having sex relations with women who are called prostitutes or 'bad' women, that is, they are women who are not in love with anyone but who make money by selling their sex relations to men who pay for 
them" (16). According to common parlance, women who have sex without love are considered "bad" while the men who pay for them need no such qualifier. Dennett goes on to state that even if these diseases can be entirely cured, "prostitution will still remain a thing to hate," indeed "will always be revolting to highly developed sensitive people" (16). That is, for now it suffices to say that prostitutes are the cause of social disease, but even if this were no longer the case, prostitutes are still themselves a social disease. Women who have sex without love are both deplorable and revolting. If sexual freedom and equality with men are really the central aims of 1920s sex reform and education, then why is the prostitute figured so negatively in this discourse? Continued and pervasive negative reaction to female sex-workers shows the near impossibility of liberating women according to productive ideology. ${ }^{16}$

Women who invoke sex and power must first defend themselves against the negative values imposed upon the prostitute. ${ }^{17}$ Because masculine productive discourse

\footnotetext{
${ }^{16}$ Although there are notable exceptions to negative feminist representations of the prostitute (see for example Camille Paglia in Sex, Art, and American Culture: Essays 1993), feminists of sex and sexuality often distinguish themselves in terms of their positive or negative attitudes toward prostitutes. A recent book of feminist essays Not for Sale: Feminists Resisting Prostitution and Pornography (2004), proclaims with vehemence that "there is a whole new generation of feminists who are resisting the sex industry" (xii).

${ }^{17}$ It is important to note that nearly all feminists, between the periods of 1800-1970, invoke the image of the prostitute as the political trump card. If there is any feminine role that feminist writers disapprove of, comparing the repudiated role to that of the prostitute will prove their point, because a general rule of thumb is that no woman wants to be a prostitute. See, for example, Charlotte Perkins Gilman in Women in Economics (1898) who refers to prostitutes as "illegitimate competitors" and insinuates that married women who do not work are no better than prostitutes (55); Emma Goldman, in "Intellectual Proletarians" (1913) seeks to check women like Gilman by making the point that the "emancipated woman ... is not aware that she too must ... sell herself a thousand times in
} 
regulates the laws regarding sex and economics, a woman who attempts to transgress these laws by inhabiting both structures simultaneously becomes the ultimate threat to a masculine economy, the greatest of all social evils. Because the prostitute is a threat to the masculine economy, laws must be instantiated in ways that protect men from that threat. Margaret Sanger writes:

Prostitution has been upheld and women segregated for man's sexual use, the government going to the extent of authorizing examinations of the women for venereal diseases to ensure the man's safety from these diseases. Yet there has been no such protection given either the woman prostitute or the wife that the man's body is free from them. (73)

To her credit, Sanger recognizes that sex as a discourse works its way into law in ways that benefit men. Legal protection for the man is logically justified as an attempt to protect the wife and family. A political silence is established in ways that encourage men to have sex widely without fear of illness or fear of social sanction. The laws regarding sex take precedence even at a legislative level. The cultural imperative of sex must be protected, and it must be protected in ways that benefit men. Sanger clearly exposes this logic, yet she misses the fact that as long as women are segregated into two classes - the virtuous woman and the prostitute - invoking sex as a discourse for women's liberation only reinforces such segregation.

Because the impetus behind sexual reform was protection of the social value of

return for her living" (180). In Three Guineas (1938) Virginia Woolf claims that daughters of educated men would "prefer to call ourselves prostitutes simply and take our stand openly under the lights of Piccadilly Circus rather than use [indirect influence]," suggesting that the only thing worse than indirect influence over society is prostitution (19). More recently, Andrea Dwarkin argues, "what is happening before your very eyes is that the pornography industry has managed to legitimize pornographized sexuality and to make it the duty of every woman to perform sexually as a prostitute" (141). 
sex, social recognition of the necessity for birth control became critical in reformer

discourse. While it was illegal to speak about birth control in the early twentieth century, sexual reform was instituted as an effort to break down such prohibitions. Many scholars argue the birth control movement was a eugenicist project, driven by fears about the decline of the white race in such popular modernist literature as Havelock Ellis's The Problem of Race Regeneration (1911), Lothrop Stoddard's The Rising Tide of Color against White World Supremacy (1920), and Madison Grant's The Passing of the Great Race (1921). ${ }^{18}$ Scholars who link birth control and eugenics reinforce the connection Baudrillard makes between production and oppression - or the ways in which the production of sexual discourse discriminates against those who do not conform to the value of sex as it is conceived in white Western intellectual discourse. ${ }^{19}$

${ }^{18}$ The list of scholars who argue that sexual reform was directly related to eugenics and racism is so large that I will not attempt to list them all here. This argument has become so mainstream as to spark a negative reaction from Sanger's grandson Alexander Sanger, who, in "Eugenics, Race and Margaret Sanger Revisited: Reproductive Freedom For All?" (2007), attempts to reclaim his grandmother's work from those scholars that call her a racist: "she was an intelligent woman but not a formally educated one. I doubt she had read or studied evolution, natural selection, or genetics. She came from one of the classes that Protestant eugenicists looked down upon and discriminated against-Irish Catholics. She was also poor and female. She had married a Jew. She had a criminal record from her days as a labor organizer. She had inherited diseases. No eugenicist would call her 'fit'" (213). Alas, Sanger defends his grandmother based on who she is and not what she writes.

${ }^{19}$ For an alternative reading of the birth control movement in America, see Andrea Tone's "Black Market Birth Control: Contraceptive Entrepreneurship and Criminality in the Gilded Age" (2000). Tone argues that immigrants, lower class women, and Jews drove the advent of the birth control movement in America. It is, according to Tone, the educational bias of the scholar that ties the birth control movement to middle-class white women: "Scholars who have studied the modern birth control movement have typically framed its history as a tale of physicians, policy makers, and reproductive rights activists. As a result, we know a lot about such figures as Margaret Sanger, legal impediments to 
Reading the early challenge to birth control legislation through Baudrillard allows us to add another layer to this argument. Baudrillard reminds us that the advent of birth control was not necessarily intended to allow women the right to choose sex whenever and with whomever she desired. ${ }^{20}$ Although the birth control pill would not come into existence until the 1950s and would not be widely available until 1961, Baudrillard's words on birth control carry resonance for sex reform in the modernist era where the most popular, and often scientifically untested, means of birth control consisted of either a sponge soaked in olive oil for the lower classes, or the combination of a cervical cap or diaphragm together with spermicidal jelly for the middle classes, while the condom was promoted only as a last resort: ${ }^{21}$

Here is the era of the pill when sexual pleasure is decreed. The end of the right to sexual reticence. Women must realize that they are being dispossessed of something essential for them to put up so much resistance (all those ghosts of 'missed' acts) to the rational adoption of the pill ... Defiance, the other's defiance, is no longer possible: all symbolic logic has been eliminated to the advantage of a permanent erection and its blackmail (without counting the tenacious lowering of the rate of sexual pleasure itself). (Seduction 19)

reproductive rights, and the medicalization of contraception but little about the business of birth control as it evolved from an illicit trade into one of the most successful 'legitimate' industries in American history" (436).

${ }^{20}$ Sanger provides proof of Baudrillard's argument in her articulation of fear over the fact that women are more concerned with economics when choosing a mate than the propagation of the species: "all over the civilized world today are being given and taken in marriage with but one purpose in view: to be well supported by the man who takes her. She does not concern herself with the man's physical condition, his hereditary taints, the cleanliness of his mind or past life, nor with the future of the race" (44). Clearly, she means her writing to be instructive, in terms of who a woman should have sex with, not just informative about sex.

${ }^{21}$ For more on the technology involved in birth control of the 1920s and 30s, see Peter Neuchal's article, "Marie C. Stopes and the Popularization of Birth Control Technology." 
According to Baudrillard, birth control was designed to increase the pleasure of men, while encouraging women to agree to sex without consequence. ${ }^{22}$ Emphasis placed on the need for contraception in women amounts to the production of the human right to orgasm - the supreme pleasure in the sex act. Women who have access to birth control no longer have a legitimate reason to say no, particularly when sex is reinforced in reform literature as pleasurable. Moreover, birth control eliminates the possibility for imagining a challenge to the supremacy of sex and orgasm. Indeed, Sanger underscores the fact that the birth control movement was not concerned with increasing the pleasure of all women:

When women have gained their economic freedom they will cease being playthings and utilities for men, but will assert themselves and choose the father of their offspring. As Bernard Shaw tells of her in one of his greatest plays, she will hunt down her ideal in order to produce the superman. (44)

Within the logic of production there are but two choices available for increasing the potential for social and political power: through sex or through labor. Either the woman gains power through marriage, which affords her the monetary funds necessary for survival, or else she can work and control her own means of support. Both options are provided by the history of what is considered power according to productive ideology.

${ }^{22}$ Proof of this masculine design of birth control can be found in the writing of sex reformers like Marie Stopes who, in Contraception: Its Theory History and Practice (1923), argues, even though there was no scientific data to confirm her theory, that the condom "robs the coital act of its full physiological benefit by preventing women from having contact with seminal secretions" (127). For Stopes, the sex act was not completely fulfilled without seminal emissions. Ideologically speaking, Stopes's theory makes sense. In a society that values the power of production, trapped or aborted emissions would mean the production of wasteful sperm, or sperm without a purposeful female destination. Could this be the reason that the use of the condom was considered "morally tainted" in the 1920s? (Neushal 225). 


\section{New Woman Feminism}

The Spectacle is heir to all the weaknesses of the Western ideological project which undertook to comprehend activity in terms of the categories of seeing; furthermore, it is based on the incessant spread of the precise technical rationality which grew out of this thought. The spectacle does not realize philosophy, it philosophizes reality. ${ }^{23}$

-- Guy Debord

Society of the Spectacle

Now the temptation of the absolute mask (the mask of antiquity, for instance) perhaps implies less the theme of the secret (as in the case with the Italian half mask) than that of an archetype of the human face. Garbo offered to one's gaze a sort of Platonic Idea of the human creature, which explains why her face is almost sexually undefined, without however leaving one in doubt.

-- Roland Barthes Mythologies

Although, as I have argued, discourse on sex education and sex reform was productively masculine in design and thus not entirely congruent with the aims of feminism, unlike Shulamith Firestone, Estelle Freidman, and Nancy Cott, I do not want to suggest that the modernist era was a politically inactive period for feminism. I do, however, argue that sexual equality and sex reform are not narratives that exemplify the ways in which women are able to reverse the logic of productive masculine discourse. ${ }^{24}$

${ }^{23}$ Because the spectacle is traditionally associated not only with women but also with femininity, it is enlightening to substitute the word "feminine" for the word "spectacle" throughout Debord's text. Such a reading highlights Debord's not-so-veiled misogyny. It should not be surprising that Debord, a Marxist, proclaims the evils of spectacle. Indeed, the spectacle challenges the supremacy of labor and economics, productive concepts that Debord thinks should be the primary focus of social relations. But it may be surprising to some feminists to see how such opposition, especially in the modernist era, can be consonant with hostility toward women.

${ }^{24} \mathrm{I}$ argue with Baudrillard that a radical challenge to the law is articulated as the ability to elude that law, to reverse it, without instantiating another ideology to take its place. History shows that sex reformers were at all times and places subject to the laws that 
Feminists have been looking for feminism of the 1910s -1930 s in all the wrong places.

The spectacle, not sex, is the locus of modernist-era feminism. Instead of focusing on the successes and failures of sexual reform, a discourse that primarily reinforces the social value of sex, focusing on the historical emergence of the "new woman," the flapper, and the film star, I argue, allows feminism to pose a radical challenge to the value of sexual production. In reading Seduction, I could not help but recognize the similarities between Baudrillard's account of the emergence of seduction and the advent of the twentieth century "new woman." With the increase in modern technology, the development of the beauty culture, and the rise of the film industry, seduction was at its cultural height in the 1910s and1920s - and women recognized seduction, not as an alternative to productive discourse, but as a lucrative challenge to that discourse. Indeed, what separates the feminism of the modernist from that of the Progressive Era is, I argue, precisely the value placed upon the strategy of seduction.

Such a perspective may be applied by reading even sex reform literature for a different emphasis. Where social reformers like Charlotte Perkins Gilman repudiated the feminine and artifice, Margaret Sanger does not. In fact, Sanger attempts to reclaim the feminine from those who would like to bring it into the realm of masculine ideology.

Sanger writes:

Certain authorities who have made vice and kindred subjects a study, assert that it is this great desire for trinkets, silk petticoats, which induces girls to sell their bodies. Such authorities fail to see the economic

dictate rules regarding sex in the 1920s and 30s. Margaret Sanger was arrested eight times during the course of her work, Mary Ware Dennett was indicted in 1928 for violation of the Comstock laws, and Marie Stopes's Married Love was banned in the US, under the Comstock Law, until 1931. 
significance of these unsatisfied desires. There is something wrong with a system of society, which allows its women to sell their bodies for such trifles, the desire for which is part of their natural development. (17)

Sanger is suspicious of the fact that "certain authorities" (namely, teachers, clergymen, social workers, and physicians) seek to link the cause of prostitution to the desire for objects that have no social meaning or value. The link between the feminine use of artifice and prostitution is an attempt to bring the feminine into the realm of the masculine, to blame socially unsanctioned sex on petticoats. According to Sanger it is the negative social value placed upon these objects that is the problem. Sanger reclaims artifice by arguing the girl's "natural development" is responsible for the fact that "laces, jewelry, trinkets, ribbons, become her world" (17). A young girl who beautifies and adorns herself is expressing an "inherent and natural desire," one "which comes down to her from primitive women" (17-18). We do not need to read this assertion only as an essentialist claim, but alternatively as a strategy.

The advent of the "new woman" in the 1910s and 20s coincides with a period in which productive ideology was presented with its greatest challenge: the mass reproduction of the female image, particularly in advertisements and women's magazines. In The Spectacular Modern Woman: Feminine Visibility in the 1920s (2004), Liz Conor conceives the modernist era as governed by a tension between the female image as a reflection of reality and the image as artifice and superficiality. For example, Conor shows that the mannequin, deriving from the dress form, took on a more realistic appearance, with a head, a face, and limbs, but then became so stylized as to be clearly an icon, not a representation of actual women. The modern woman came to represent the 
embodiment of this tension by artificially fashioning her appearance, in accordance with representations of women in magazines and advertisements, which allowed her control over how she was received publicly. According to Conor, social mobility imagined for women in the 1920s came about, not only through the assertion of sexual subjectivity, but also through practices of appearing - that is, through artifice. Because female images carry social meaning, women could change their public reception as often as they changed their clothes: are you a "beautiful charmer" who delights, "a new England Woman" who thinks, or an "Outdoor Girl” who cavorts (Malnig 43)? ${ }^{25}$ Through revaluing artifice, I argue, we can divorce feminine representation during the 1920s from productive ideology in a way that does not ascribe meaning or value to the public presence of the "new woman," but rather challenges that ideology, blurs the lines between reality and artifice, illusion and essence.

Drawing from the work of Joan Rivière, Simone de Beauvoir, and Guy Debord, Conor argues that Western society is governed by the ideology of ocularcentrism: the equation between seeing and knowing. Ocularcentrism can be seen as a slice of the larger pie of what Baudrillard calls productive ideology whereby appearing unproblematically reflects being. Conor argues the concept of the "modern appearing woman" overturns ocularcentrism: "the feminine as spectacle could upset the correspondence between image and reality" (27). Although Conor does not invoke Baudrillard in her study of

\footnotetext{
${ }^{25}$ In "Athena Meets Venus: Visions of Women in Social Dance in the Teens and Early 1920s" (1999), Julie Malnig argues that women in the early teens and twenties were able to imagine themselves as "new women" through images and articles in dance craze magazines.
} 
women and modernity, the similarities between the woman-as-spectacle and the feminine as seduction are palpable. ${ }^{26}$ Reading Conor through Baudrillard's theory, I argue that the modern woman reverses productive ideology by seducing meaning through artifice.

Conor's work is particularly helpful in explaining what Baudrillard says about the transgressive potential of seduction. Not only does the ability to seduce meaning through artifice challenge productive ideology, it strikes at the core of the productive structure. Conor writes, "appearing disrupts the foundational dichotomy of subject and object by disrupting the traditional articulation of sexual difference along this divide" (8). In short, the "modern appearing woman," in turning herself into a spectacle for public consumption, transgresses the boundaries between subject and object. The idea that a woman asserts herself as subject through turning herself into an object not only negates the notion that the object position lacks agency and authority, but it also challenges the political backslash, the concept of the object position as distinct from and in opposition to the subject position. Changing focus from the modern woman as sexually empowered to the modern woman as transgressing the laws of production through artifice and illusion has the effect of showing the ways in which the "modern appearing woman" was able to

\footnotetext{
${ }^{26}$ One very important difference between Baudrillard's theory of seduction and Conor's theory of the spectacular modern woman is that Conor's theory does not go far enough, and thus ends up perpetuating productive discourse on the need for sexual agency. Conor uses the modern appearing woman to argue for her sexual subjectivity: "by constituting herself as spectacle, she was asserting her sexual agency" (13). Effectively, what this argument does is to bring the modern woman back into the realm of productive ideology - to say that seduction is what allowed women to access sexual production. In contrast, I would like to argue that seduction is what allowed the modern woman to overturn the ideology of production. A woman does not need the ideology of sex to assert agency: to do so reinstates the subject/object divide, which Conor very nearly overturns. That Conor misses the larger theoretical implications of her feminist intervention in no way diminishes the importance of her argument.
} 
nullify the subject/object divide.

Moving away from discourse that espouses a link between sex and feminism requires either a re-examination of those feminist writers and public figures like Margaret Sanger, who are constructed as sexually empowered, or, what I offer here, a closer examination of those radical women of the modernist era who reverse the laws of productive ideology and binary logic through the use of spectacle, seduction, and artifice. ${ }^{27}$ Focusing on such modernist figures as ballroom dancer Irene Castle, as well as authors and screen writers Elinor Glyn and Anita Loos, I argue that social and economic mobility, as imagined by authors and public figures of the 1910s-1930s, was contingent upon a woman's ability to "seduce." As the "new woman" began to maneuver across the social sphere, and interact publicly with men, it does not make sense to see sexual

${ }^{27}$ In terms of sexual reform, one might examine more closely the work of an oftoverlooked British reformer and feminist, Stella Browne, who, while purporting interest in sexual reform, does not perpetuate the value of sex for all women. In a paper given at the 1915 meeting of the British Society for the Study of Sex Psychology, entitled "The Sexual Variety and Variability Among Women and Their Bearing Upon Social Reconstruction," Browne challenges the assumption that women experience sex in the same manner as men, and that there is any specificity or particularity to the location of her pleasure. In fact, Browne is one of the few reformers who argued that sex consists of ideology rather than truth: "sex is complex, and in humanity, largely mental and imaginative." Furthermore, instead of using the word "equality" in regard to the relationship between men and women, Browne uses the words "co-operation" and "companionship," suggesting social exchange and thus forestalling any belief that women should adopt the attitudes of masculine ideology. In a strategic move consistent with what Baudrillard says about feminists who adopt rather than critique masculine ideology, Browne writes, "I am utterly opposed to the 'double standard'; but I believe the 'double standard' is an integral part of a certain social order: to repudiate that standard, while upholding and accepting the social order, seems to me absurd" $<$ http://homepages.primex.co.uk/ lesleyah/variety.htm>. Here Browne suggests not only that one cannot fight the system from inside the system, but also that equal participation within the social order, from which the double standard originates, does not indicate revolution. 
liberation as the impetus behind social liberation. Indeed in many modernist works, such as the novels Gentlemen Prefer Blondes and Jacob's Room, along with the novellaturned-Hollywood film "It," women who seduce masculinity achieve social and economic gain, while those openly invested in the production of sex struggle against the laws that constitute social value. It is my contention that woman of the modernist era, regardless of type, class, or social status, gained social liberation not through opposing masculine ideology (or insisting on sexual equality) but by seducing it, thus undermining the productive sex/power dynamic.

In Steppin' Out: New York Nightlife and the Transformation of American Culture (1984), Lewis Erenberg follows the career of the Castles, a middle- class, married dance team that weakened class and social boundaries in the early twentieth century. Erenberg's discussion of Irene Castle provides an example of what Liz Conor refers to as the spectacular modern woman, while simultaneously supplying evidence of the ways in which seduction overturns the masculine ideology of production. Erenberg writes, Irene conveyed images of rebellion from the social constraints of the day. She danced black dances, made fabulous sums of money, associated with the wealthy and with blacks, became a leading woman of her day, and defied the conventions to advocate that women could publicly cross the barrier of the double standard and enjoy life more equally with men. (169)

Against an upper-class society opposed to the "immorality" of modern dances (because of their lower-class, primitive, and sexual associations), Irene emerges as triumphant in her ability to reshape and redefine herself and popular dances in a way that was socially acceptable and economically viable. While Erenberg insists that Irene crossed "the barrier of the double standard," which implies greater sexual freedom, his essay fails to provide 
poof for this claim - thereby revealing how unthinking is the assumption that the modern

woman desired sex and sexual equality. Irene never insisted on sexual equality and adamantly denied her sexuality in public; it was this that made her fortune. Irene relied on the powers of seduction, the strategy of appearance and artifice, to challenge traditional upper-middle class beliefs. ${ }^{28}$

In Seduction, Baudrillard states that the strength specific to the feminine order is the power to seduce. The power of seduction trumps political, economic, and sexual power, specific orders of the masculine. Baudrillard states, "the capacity immanent to seduction" is its ability "to deny things their truth and to turn [reality] into a game, the pure play of appearances, and thereby foil all systems of power and meaning with a mere turn of the hand" (8). Irene's slim, child-like, public appearance, her insistence on her husband as master of their success, and her advertisements about the health benefits of dancing, seduced the upper-middle class into believing in her gentility and thus the gentility of her revised modern dance. Irene emerged as "a winsome boyish, American

\footnotetext{
${ }^{28}$ Many scholars note the modern dance craze as having a significant impact on modernity, the reconfiguration of social mores, and the burgeoning presence of the "new woman." However, despite the wide variety of dance teams present in the early 1900s, including Maurice Mouvet and Florence Walton, much scholarship tends to focus primarily on the figures of Irene and Vernon Castle. (See, for example, Ann Douglas and Julie Malnig). Erenberg's use of language in his short description of Florence Walton provides some insight as to why Irene emerges as the poster child for social dance over her "nearest rival": "Florence Walton's beauty was more voluptuous compared to Irene's elegant girlishness, and she and Maurice were both swarthier in complexion. Maurice and Walton represented the underlying currents of sensuality that emerged as significant possibilities for the dance and for men and women" (165). To put it bluntly, Florence was emblematic of blatant sexual desire. Her divorce from Maurice in 1920 and her later remarriage kept her from appearing as an example of women's social value. The marginalization of Walton renders problematic both the ideology that women had sexual freedom in the early twentieth century and scholarly insistence upon an end to the double standard.
} 
girl-a pal" (168). She projected the image of an innocent, devoid of sexual passion, and a model of good health. Irene appeared subordinate, malleable, and non-threatening. She did not defy or rebel against her feminine role any more than she accepted it as truth; she played with it. A play of appearance allowed Irene the flexibility to cross and re-cross social and economic boundaries.

Anita Loos's novel Gentlemen Prefer Blondes: The Illuminating Diary of a Professional Lady (1925), received great critical acclaim from James Joyce, William Faulkner, and Edith Wharton who deemed Loos's text "the great American novel (at last!)" (Gentlemen Prefer Blondes xi). As I argued in the last chapter, Wharton's praise of Loos acknowledges the character Lorelei Lee as a modern reincarnation of Lily Bart. Loos's Lorelei marks a shift in female characters of the modernist era who are able to "make it" in a masculine productive world without supporting or opposing masculine ideology. Not unlike the beloved Irene Castle, Lorelei Lee encapsulates the image of the "new woman" by appearing slight, boyish (the contemporary feminine ideal), and full of vitality. So, too, does the story of Lorelei present a socially and economically successful woman from a humble background created under the lights of the entertainment industry. Like Irene, Lorelei crosses social boundaries with little opposition. And, as in the case of Irene, critics cannot help but associate Lorelei's economic and social acquisitions with “sexual liberation.” In “Taking Blondes Seriously” (1995), Susan Hegeman argues,

We might say that for Loos and many other 'professional ladies' of the 20 's the inescapable subtext of their lives in the public sphere was sex... Returning to the elaborate evasions of the question of sexuality in Lorelei's diary, we can begin to see how Loos in effect rewrites this subtext in such a way that the heroine actually benefits. (539) 
Hegeman reads Lorelei's use of the word "education" to mean sexual favors for which Lorelei gains expensive jewelry from her gentlemen friends. To suggest that Lorelei’s social and economic advancement is the result of sexual endeavors would limit the scope of power that Lorelei wields in a society not only insistent on the male as sexually dominant, but also on the propagation of masculine productive discourse. The sex act would suggest an end to seduction, surrendering power to masculine dominance through orgasm. In contrast, Lorelei's challenge to productive ideologies like sex and work is undefeatable.

When Lorelei describes her early experience in Arkansas, before she moves to New York City, she underscores the importance of her most resonant life lesson: sexual acts have deadly consequences. After attending "business colledge [sic]" (24) for all of seven days, Lorelei is offered job as a stenographer working for a man named $\mathrm{Mr}$. Jennings. When Lorelei walks into Mr. Jennings's apartment, to find a girl "famous all over Little Rock for not being nice," she attempts to murder him (25). At her trial, and before the court, Lorelei denies her role in the attempted murder of Jennings to the judge, even as she admits her guilt: "I had a revolver in my hand and it seems that the revolver had shot Mr. Jennings" (25)..$^{29}$ Lorelei's paradoxical statement at once upholds the law as all knowing and powerful, and denies agency. Lorelei cannot deny the truth in front of the judge, but her murderous act was not an exercise of power or opposition; at the moment of his shooting, she was "out of it" (25).

${ }^{29}$ Importantly, Lorelei is not in the subject position, grammatically speaking. The gun shot. She did not. The gun more or less went off, "had shot," undermining any agency. 
It is Lorelei's appearance as weak before the powers of the court that seduces the judge and jury, and ultimately leads to her acquittal. That Lorelei's strength is paradoxically also her weakness is consistent with what Baudrillard says about seduction: "To seduce is to appear weak. To seduce is to render weak. We seduce with our weakness, never with strong signs or powers. In seduction we enact this weakness, and that is what gives seduction its strength" (83). Thus when Lorelei's lawyer reminds the judge and jury that, "practically all had either a mother or a sister," in effect, he rendered the court weak to act against her (25). Indeed, at this reminder, "all the gentlemen in the jury cried" (25). Lorelei, in getting the jury to mirror her weakness, undermines the strength of the judicial systems. The jury was out on Lorelei for only three minutes, forcing the reader to recognize her strength as one that can enervate systems of power, even as she appears to uphold them. In the courtroom, Lorelei learns that there is an alternative to sex and power, and that is the play of seduction.

It is not coincidental that Lorelei decides to pursue an acting career after her trial. Baudrillard calls the cinema, the "only important constellation of collective seduction produced by modern times" $(95){ }^{30}$ Lorelei realizes that her potential for social success is

\footnotetext{
${ }^{30}$ Notably, Ann Morey, in "WWould You be Ashamed to Let Them See What you Have Written?' The Gendering of Photoplaywrights, 1913-1923" (1998), states: "Many film historians have noted the considerable presence of women in filmmaking early in the development of Hollywood. Not only were women directors comparatively common in the first two and one half decades of the business in America, but Martin Norden has also observed that screenwriting was an aspect of the industry that women 'quickly dominated.' Indeed, screenwriting and editing may be two of the few crafts within Hollywood that did not suffer the near-complete expulsion of women as the industry developed" (83). Thus, the advent of the cinema in the modernist era was not only an example of concentrated, collective seduction, as Baudrillard claims, but also of an industry in which women dominated the field.
} 
contingent on appearance and artifice: "I mean it was when Mr. Jennings became shot that I got the idea to go into the cinema, so Judge Hibbard got me a ticket to Hollywood" (25). The fact that Mr. Jennings "became shot" suggests that this is his condition, that there was no doer behind the deed. The result of the trial convinces Lorelei that her power over the judge and jury is the same power that actresses wield over their audience. Baudrillard argues that, "the great stars or seductresses never dazzle because of their talent or intelligence but because of their absence" (96). Certainly what makes Lorelei seductive is not the presence of any specific quality, but what her audience can imagine about her. This is made evident in the scene where Lorelei explains how she acquired her name: "So it was Judge Hibbard who really gave me my name because he did not like the name I had because he said a girl ought to have a name that aught to express her personality. So he said my name aught to be Lorelei which is the name of a girl who became famous for sitting on a rock in Germany" (26). When Lorelei takes on a name given to her by the judge, she shows her ability not only to become the mirror of masculine desire, but also to deny agency in overturning meaning-making systems. While the reader may recognize Lorelei as the siren from German myth who sits on a rock luring shipmen to their death by distracting them with her singing, our Lorelei turns the myth around to indicate the siren's lack of agency. She is unthreatening and merely resting.

The absence of any distinct or overpowering quality in Lorelei, her malleable appearance, and her career as an actress drive her benefactor Mr. Eisman's desire later to remove Lorelei from Hollywood. In her diary, Lorelei explains Eisman's proposition: “A 
girl with my brains ought not to be in the cinema, but she ought to be educated so he took me out of the cinema so he could educate me" (26). Clearly, Mr. Eisman did not have the good fortune of reading Lorelei's diary. The reader knows that Lorelei is not intelligent in the traditional sense, as is exemplified by her various misspellings and her claim to cultural ignorance (the Eyeful Tower of Paris, for example); thus it is plausible to read Mr. Eisman's intentions as sexual. This interpretation, however, fails to take into account the power that exceeds the limits of sex, the power of seduction. Sex has an end. Seduction is infinite.

That Lorelei's primary interaction with Mr. Eisman revolves around her time in Hollywood indicates that her "education" was not sexual. This is where Baurdillard's theory becomes particularly relevant: "[Actresses] were no longer beings of flesh and desire, but transsexual, suprasensual beings... endowed with a power of absorption equal to and rivaling the real world's powers of production" (95). Actresses constitute a blank face eternally ready to take on symbolic meaning through makeup, costume, and lighting. Lorelei's play on illusion absorbs the meaning attributed to her by Eisman. She merely has to show that she is engrossed in her education: "Mr. Eisman likes me to have what the French people call a "salo" [sic] which means that people all get together in the evening and improve their minds. So I invited all of the brainy men I could think up" (7). Lorelei becomes the mirror of Eisman's expectations by flippantly thumbing through novels, entertaining "literary people," and introducing Eisman to famous authors. Her formal "education" only demands that she play her part, that she continue to meet 
Eisman's meager challenges. Lorelei would not do well to question or oppose Mr.

Eisman's belief that she needs to be educated. Instead, she plays on it.

Baudrillard argues that "the law of seduction takes on the form of an

uninterrupted ritual exchange where seducer and seduced constantly raise the stakes in a game that never ends" (22). Lorelei's success is dependent on the fact that she never raises the stakes higher than the stakes involved in a game. She simply has to play. On the day of her birthday Lorelei expects to receive a diamond ring from Eisman because "a gentlemen who has a friendly interest in educating a girl... would want her to have the biggest square cut diamond in all of New York" (7). But Lorelei receives a smaller ring than she anticipated. Instead of complaining about the size, thereby opposing Eisman and possibly risking offence or his feelings of emasculation, she raises the stakes: "So I told him that I thought it was quite cute, but I had a headache and I had better stay in a dark room all day and I told him that I would see him the next day, perhaps" (7). Here Lorelei offers appreciation, a drop of a thank you rather than gushing appreciation. She suggests that her headache is brought on by disappointment without clearly stating so. She also suggests that she will not see Eisman again without actually threatening him. That very evening Eisman appeared at Lorelei's apartment with a "very very beautiful bracelet of square cut diamonds" (8). Lorelei's seduction becomes a game, a competition, in which Lorelei always emerges the champion. From Eisman alone Lorelei receives a trip to Paris, London, and Vienna, a bracelet of square-cut diamonds, a (small) diamond ring, a string of pearls, an emerald bracelet, and cash. In this way, Lorelei overturns the laws of 
production, which equates a woman's material gain with hard work and labor, on the one hand, or sexual favors, on the other.

Lorelei's meeting with Freud (or Froyd as she refers to him) is not only an outright denial of sexual desire, but also the refusal of productive reasoning. Debora Saville states, "Possibly the most significant social paradigm of the twentieth century, Freudian psychology made its way into the larger culture, first through bohemian ideology and then the flapper and jazz cultures" (63). In the 1920's salon, social interaction included the interpretation of dreams, suggesting an increasingly "liberated" attitude toward speaking about sex and sexuality. But Lorelei denies any association with the physical, sexual manifestations implied by such freedom of speech. When Lorelei explains to Mr. Stoddard that she has been worried and sleepless, and finally breaks down in front of him, Stoddard concludes that Lorelei should visit Freud. Mr. Stoddard, no doubt, believes that Lorelei is one of Freud's sexually repressed "hysterics."

In order to uncover Lorelei's latent sexual desires, Freud would need to analyze her dreams: "So Dr. Froyd asked me what I seemed to dream about and I told him that I never really dream about anything" (90). The absence of dreams suggests that Lorelei has no latent sexual desire. As such, she is not a visible threat to the social value of sex, which seeks to hold women morally responsible for the sexual waywardness of men. In his essay on the flappers of the 1920's Yellis states, "women were supposed to be the unwilling victims of animal desires, resigned to sexual intercourse solely for the benefit of the continuation of the race" (46). Lorelei's interaction with Freud is testament to the fact that she has no such claims on sexual equality. Indeed, she denies both sexual 
repression and desire for masculine power: "So then he seemed very intrigued at a girl who seemed to do everything she wanted to do" (90). Lorelei's refusal to allow Freud to derive sexual meaning from her discourse reverses the laws of sexual discourse through a play of appearances, the continuous act of seduction. She has no untapped sexuality, no latent sexual desires. And yet she is able to experience pleasure, to do everything she wanted to do. Effectively, Lorelei is able to reverse the law of masculine productive discourse on sexuality. Elizabeth Young Bruehl argues that "When Freud explains that 'Libido is invariably and necessarily of a masculine nature, whether it occurs in men or women ...,' he means primarily that libido is always active" (19). Lorelei's seduction challenges not only the existence of libido but also the feminine as passive. For even in lacking sexuality, she maintains both agency and authority, rendering the active/passive sexual analogy meaningless.

Lorelei and seduction exist purely outside the realm of psychoanalysis: "So Dr. Froyd looked at me and looked at me and said he did not really think it was possible" (90). Freud cannot make a diagnosis because he cannot attribute meaning to a woman who does not lend evidence to the primacy of sex in society. "So then Froyd said that all I needed was to cultivate a few inhibitions and get some sleep" (90). Freud cannot break through Lorelei's barrier of appearance, something psychoanalysis tries to do in order to expose the "truth" about sexuality. As discussed earlier, in Forget Foucault Baudrillard writes, "we act as if the sexual were 'repressed' wherever it does not appear in its own right: this is our way of saving sex through the 'sex principle.' It is our moral system (psychic and psychoanalytic) which remains hidden behind the hypothesis of repression 
and which governs our blindness" (42-43). Specifically, because sex and sexuality have come to govern society, wherever it does not exist we must speak of sex in terms of repression. This is the genius behind psychoanalysis, its ability to reinforce the structure of sexuality, to insist on transparence, even within the absence of sexual discourse. It is only a question of production. Loos's Lorelei suggests a similar position to that of Baudrillard, that the ideology of Freudian psychoanalysis imposes sexual discourse upon women, that psychoanalysis is flawed in its attempt to create sexual meaning even where it does not exist. Thus, where Freud cannot find evidence of sexuality in Lorelei, he suggests that she should go out and find it by developing repression and dreams. Lorelei does not speak in a way that allows Freud to make sense of her because her language is artifice. It is not a cover for anything.

Lorelei seduces the reader in her very nonsense. It is within her discourse that the character Lorelei seduces us, the readers of her diary. When visiting Paris, Lorelei claims a desire to experience culture and become educated in French history: "We read all of the famous historical names, like Coty and Cartier and I knew we were seeing something educational at last ... So when we stood at the corner of a place called Place Vandome [sic], if you turn your back on the monument they have in the middle and look up, you can see none other than Coty's sign" (52). That Lorelei equates education with jewelry stores and turns her back on historical monuments in order to get a better view of perfume signs, challenges not only what we think of as knowledge and culture, but does so in a way that appears non-threatening: she's absurd, laughable, and ridiculous. (The sense of turning one's back on history is also significant to what I have been arguing 
about the seduction of feminism, whereby feminists challenge rather than accept the masculine structure of history). Baudrillard argues that language has seductive potential to the degree that rational meaning is impossible to ascertain: "only signs without referents, empty, senseless, absurd and elliptical signs, absorb us" (S 70). Thus, Lorelei's horrendous spelling and her laughable knowledge of geography, history, philosophy, and art serve to distract us from knowing and thus controlling her power to reverse productive ideology. Her weakness in formal knowledge ("how much francs is in money") (53) is turned into her greatest strength. As we laugh at her antics and her obvious mistakes, we lose the ability to judge her as menacing. Loos's creation of Lorelei reverses the power of production too because she is able to acquire capital without actual labor, companionship without engaging in sex, and because she crosses all barriers of social restriction. But this is not something specific to Lorelei. She is a figure of seduction.

Like Irene Castle, Lorelei denies pre-conceived notions also about the debauchery of the flapper through an insistence on gentility. Although the term "flapper" was defined literally as a girl who had not yet reached the mature age of womanhood, the 1920s associated the term with sexual proclivity and immoral behavior. The origination of the term "flapper" allowed room nonetheless for that necessary bit of ambiguity, which made it possible for social mobility. How is it possible that an innocent, gawky, and boyish persona could threaten the social value of sex? Lorelei proves that a simple denial of sexual intention opens many a socially barred door. In order to seduce Mr. Spoffard, for example, a wealthy, "moral," eligible American bachelor who remains single due to the immoral implications of the American "new woman," Lorelei professes her own disgust 
about the present state of women: "So I told Mr. Spoffard that I really felt just like his mother feels about all of the flappers because I am an old fashioned girl” (79). By professing herself "old-fashioned" Lorelei suggests sexual passivity and chastity even as her dress and appearance signify her modernity. Lorelei compounds denial with a moral call to action. She tells Mr. Spoffard that she is in the throes of saving her young wayward flapper sidekick: "I told him how I was having a hard time reforming Dorothy and I would like to have him meet Dorothy so he could tell me if he really thinks I'm wasting quite a lot of time" (79). Lorelei's seduction is complete when she frames her relationship with Spoffard with the illusion of similar interest - they are co-conspirators in social and sexual reform. Playing on illusion, Lorelei is allowed access to the homes of English aristocracy, travels the world, and, ultimately, marries into a wealthy influential family - all privileges traditionally reserved for the upper classes. ${ }^{31}$

In the novella "It" (1927), originally serialized in Cosmopolitan magazine in 1926, and made into a major silent motion picture staring Clara Bow (best known as the "Hollywood It Girl”) as Betty Lou Spence, British author and screenwriter Elinor Glyn exposes the strategy of Loos's character Lorelei through her coinage of a word that becomes representative of the 1920s "new woman." Throughout the years, scholars have

${ }^{31}$ A notable difference between Gentlemen Prefer Blondes, the novel, and the Howard Hawks version of the Hollywood musical released in 1953, starring the much more sexualized and curvaceous Marilyn Monroe, is that by the 1950 s, Hollywood attempts to halt Lorelei's seduction, whereby Lorelei is made to pay for her attempts to overturn masculine production: being tossed out onto the streets of Paris without a single penny, Lorelei is forced to get a job in a nightclub, and eventually is arrested for stealing Madame Beekman's diamond tiara. It is notably Lorelei's brunette sidekick Dorothy who, appearing in front of the courtroom in a blonde wig, is able to save Lorelei from going to jail. 
sought to define "It" in terms of sex appeal or to use it as a euphemism for sexuality, as Marsha Orgeron does in her assertion that the film title "resonates in the realm of the sexual" (76). ${ }^{32}$ However, I argue that to do so completely devalues the function of "It," the way the term helps challenge the importance of sexuality to women's new public role in society. In fact, "It" can be seen as the key concept in a blossoming seductive feminism present in the modernist era, or what one could even call "FemITism." The fact is that Glyn does not define "It" in any way that can be directly related to sex. Her definition in both the novella and in the film is purposefully vague and meaningless. A productive society could not possibly let "It" rest until "It" comes to represent a particular value in society, specifically until "It" confirms the value placed on the importance of sex appeal to a woman's having "made it." The reason "It" becomes such a powerful symbol for the 1920 s is because it cannot be reduced to a single meaning.

In the opening lines of her novella, Glyn writes of her main character John Gaunt, "He had that nameless magnetism which can only be called "'It,' and cats - as well as women - always knew when he came into the room” (9). Later Glyn writes again, "There was no beauty in him, she was right - but there was some strange magnetism, and perhaps it was augmented by his absolute indifference" (10). What we know about "It"

\footnotetext{
${ }^{32}$ An exception is found in the article "It" by Joseph Roach who argues that "It" is, "the power of projecting contradictory essences in the same role, even in the same gesture. This quality points to a definition of It that moves beyond the tautology of innate charm and enters into the realm of theatrical and cinematic technique. Theatrical performance is the simultaneous experience of mutually exclusive possibilities truth and illusion, presence and absence, face and mask" (559). Although Roach uses the term specifically to connote a technical theatrical skill, thus suggesting that "It" can be produced, he comes close to what Baudrillard defines as seduction. Only seduction is not just about contradiction. It is about eclipsing the truth through illusion, challenging presence through absence, and obscuring the face through the mask.
} 
from Glyn's novella is that you can't name it. You can't explain it according to the laws of productive reasoning. It has nothing to do with physical appearance, and is marked not by difference but rather by indifference to social value. Although the term "It" is now primarily associated with women, indeed went on to characterize many young Hollywood starlets, the term was not originally meant to connote a specific gender: both women and men could have "It." The refusal to account for exactly what "It" is made the film "It" a huge success, and became the impetus behind woman's desire to mirror the bee-stung lips of Clara Bow's character Betty, adding to the already popular trend of the female bob the nostalgic hairstyle we continually attribute to woman's public presence in the roaring '20s.

The arbitrary nature of "It" allowed Glyn the power to seduce society, which helps to account for the fact that Glyn was the highest paid Hollywood screen writer of the 1920 s. ${ }^{33}$ Significantly, the film, unrelated in many ways to the novella, begins not with the introduction to character or plot but with a definition of the term. This draws attention not only to the way productive ideologies structure society but also to the obsessive need to assert meaning and social value at every turn. The strategic move that Glyn makes in this film is that she seductively promises meaning and denies it simultaneously. The opening words on the film screen appear as such: "It is that quality possessed by some which draws all others with its magnetic force. With 'It' you win all men if you are a woman - and all women if you are a man. It can be a quality of the mind

\footnotetext{
${ }^{33}$ Joseph Roach writes, "For a fee of $\$ 50,000$, Glyn was persuaded to lend her orphic voice to say that Bow had 'It.' Rivals complained that this coup made Glyn, at fifty grand per word, the highest-paid writer in Hollywood, but the moniker stuck fast to the actress until its re-ascription to Marilyn Monroe" (558).
} 
as well as a physical attraction." The fact is that some people have "It" and some people do not, leading us to question: Who has it? Where does it appear? And where can I get "It?" However, Glyn is adamant about the fact that you cannot make "It" or produce "It." Furthermore, "It" has everything and nothing to do with gender and thus everything and nothing to do with sex. Although Glyn's quotation seems to reinforce the heterosexual norm, the word "win" is particularly important in discerning what it is. "It" is a game you play, a strategy. "It" is a force that attracts the desire for productive reasoning or meaning and remains the victor, for "It," like the face of the Hollywood film actress, masks emptiness.

In a quotation that links her vision for the film to the social success of Lorelei Lee in Gentlemen Prefer Blondes, while also asserting their important differences, Glyn writes, "Every evening, in America, eighteen million blondes prepare to dine with gentlemen." That is, according to Glyn, every night modern women take Lorelei's seduction out to play. The modern woman fashioned herself as blonde after a character that made it in a masculine world without embracing masculine values. But Glyn's "It" girl Betty/Bow is a brunette who conspicuously stands out at dinner in a room full of blondes. Apparently, Glyn wants her literary movie-going girl to know that "It" has no specific hair color. It is a strategy and not a character trait. "It" is not a game that only blondes can play. Because "It" is not about possessing an identifiable quality, according to Glyn, our modern woman has missed the point: "It" is not essence.

Significantly, the opening scene of the film takes place in Waltham's department store where co-worker Monty tells his friend and boss Cyrus Waltham, "You don't have 
it." Monty, on the other hand, who spends his workdays reading Cosmopolitan magazine and living off of Cyrus's social connections, apparently does. As the owner of Waltham's department store, and Betty/Bow's boss, Cyrus represents not only the upper class but also men dependent on production. Cyrus's success is brought about by labor and work ethic, while Monty's success is due to his seduction. In this way, Glyn is able to spell out the way in which relationships in the film will play out in a dual/duel manner: those who have "It" seducing those who do not. This early scene with Cyrus and Monty not only foreshadows Cyrus as Betty/Bow's future romantic interest (as she too has "It," indeed, is the embodiment of it) but also her competitor in the film: Betty/Bow continually matches her seduction with and against Cyrus's productive values. From the beginning Glyn also reinforces "It" as primarily a game with two players. For example, Betty/Bow and Cyrus's first date comes about as a result of the fact that Cyrus loses a bet with Betty/Bow regarding her identity: he does not recognize at dinner that Betty/Bow is his employee from Waltham's. What makes Betty seductive is that Cyrus cannot guess who she $i s$.

When Glyn makes her cameo appearance at the Ritz (another nod to Loos, perhaps) where the "It" girl Betty/Bow, her friend Monty, and her future suitor Cyrus are dining, she takes another opportunity to define "It" for a room full of adoring fans. "It," Glyn tells Manhattan's dining elite, is “self confidence and indifference as to whether you are pleasing or not - and something in you that gives the impression that you are not all cold. That's it." Reinforcing the notion that "it" does not have a value, "it" does not concern itself with pleasing society or opposing it. Glyn's use of the words "that's it" 
constitutes a double entendre confirming "It" as a matter of word play. "It" is not about being so much as it is about playing at being. "It" is not concerned with who you are, rather that you put forth an impression, or an idea, regardless of whether that impression is true or false. "It" is about seducing meaning, denying the spectator the means by which to deduce, induce, or especially to produce it (meaning).

Although the presence and consequences of sex and sexuality are easily discernable within the film, as made evident by the fact that, to her feigned horror, Betty's suitor Cyrus tries to kiss her on their first date and by the fact that Betty lives with a single mother Molly who is suffering from illness and struggling to feed and care for her child, sex is never presented as that which empowers women in the film. Rather, sex is presented as governed by the laws of social value in ways that threaten to strip women of their power, to strip them of "It." When Betty/Bow receives a sexual advance from Cyrus on their first date, she stops him and says, "So You're one of those minute men the minute you know a girl, you think you can kiss her." Betty/Bow confirms sex as productive in the film, and forever linked to knowledge of the female other. Although Betty/Bow pretends to be shocked and outraged by Cyrus's advance, once up in her room, she smiles and hugs her teddy bear to let the audience know that she is engaged in a seductive game, one that requires her to play a part that will deny him access to both knowledge and sex. Betty's power over Cyrus is not that she withholds sex from him. Her power is to be found in the game she plays, that quality that gives her "It." To express sexual desire for Cyrus would be to allow productive ideology to win, to make "It" about sex. 
Outside the realm of game play, sex in the film is generally what disempowers women and devalues them in society. This is made evident in a scene where two social reformers, complete in all-black dresses with high, lace collars and big hats, arrive at Betty/Bow's apartment looking for Molly, whose child they want to take into protective custody. Pretending to be Molly, Betty/Bow replies, "If women like you would stay home and have babies of your own, we'd all be better off." Sexual reformers emerge as the biggest drain on society, suggesting that sex and sexuality are governed by the productive mandates of social morality. Cyrus mistakenly comes to believe that Molly's baby belongs to Betty/Bow, which causes him to dismiss her as a gold-digger once she is confirmed as tainted goods. Clearly, Glyn does not attribute the power of the "new woman" to sex any more than Loos does.

\section{The Limits of Seduction}

To proclaim women's sexual agency from the 1910s through the 1930s is clearly not the argument feminists should make. The "new woman's" agency is best defined in relation to seduction, even and especially when a woman makes her living from sex-work as Virginia Woolf's characters Florinda and Laurette do in Jacob's Room (1922). Although revisionist feminists focus on individuals like Margaret Sanger and Helena Rosa Wright in order to create a more sex-positive view of the modernist era, there is greater evidence of a systemic women's movement interested in censoring sex and sexuality wherever it appeared in public. In "Publication and 'Public Women': Prostitution and Censorship in Three Novels by Virginia Woolf," Celia Marshik reminds us of the more pervasive type of sexual reformer present in the early twentieth century: 
"As social reformers worked to censor women's bodies through penal and medical codes visited upon prostitutes, who brought 'private' sexuality into the 'public' sphere, they also pressed government agencies for censorship of writers who explored sexuality within published works" (854). Societies such as the Women's Christian Temperance Union, The National Congress of Mothers, The General Federation of Women's Clubs, The Women's Cooperative Alliance, and the American Library Association attempted not only to censor sexual content in literature, theatre, and film, so as to prevent young people from engaging in vice, but also lobbied for anti-prostitution legislation. ${ }^{34}$ While Marshik concludes that "by deleting overt discussions of sexuality, Woolf was able to raise eyebrows without publishing - or being prosecuted for - anything obscene" (869), I argue that overt sexuality was left out of Jacob's Room in order to foreground female agency without reinforcing the masculine ideology of sex. What allows agency and authority to Woolf's Florinda is not her admission of prostitution; rather, it is her ability to mirror the desires of Jacob. Florinda's presence in the story is not only dependent upon the fact that Woolf initially refrains from using the term "prostitute" to describe her, but also on the fact that Florinda never reveals the economic reality of her relationship to Jacob. Once that reality is unveiled not only does Florida disappear forever from Jacob's life, she is also forced to suffer the consequences of her sexual position: pregnancy and possible abortion.

\footnotetext{
${ }^{34}$ For more on the reform efforts of women in pro-censorship activism, see Allison Marie Parker's Purifying America: Women, Cultural Reform, and Pro-censorship Activism, 1873-1933 (1997) and Leigh Ann Wheeler's Against Obscenity: Reform and the Politics of Womanhood in America, 1873-1935 (2007).
} 
Woolf's Jacob's Room is a veritable ode to the spectacle and its challenge to the pervasive ideology of ocularcentrism that dominates early twentieth century England. This is made evident throughout the novel as characters depend heavily upon sight in order to make sense of the world around them. From the narrator's anxiety-ridden question, "What does one fear?" answering immediately "The human eye" (81), to the fact that the story climaxes with Jacob in Greece among the statues of ancient gods, where, according to Liz Conor, ocularcentrism, originates, productive ideologies are continually rendered problematic. ${ }^{35}$ Woolf's narrator underscores the importance of ocularcentrism not only in relation to the "new woman's" social mobility but also in relation to the mobility of the prostitute. When we are first introduced to Florinda, the narrator focuses on her face: "By a trick of the firelight she seemed to have no body. The oval of her face and hair hung beside the fire with a dark vacuum for background. As if dazed by the glare, her green-blue eyes stared at the flames. Every muscle in her face was taut. There was something tragic in her thus staring - her age between twenty and twentyfive" (74). Devoid of body, existing purely as face, the narrator not only establishes ocularcentrism as our primary means to knowledge of female essence but also shows that seduction is not sexual, not of the body. What initially attracts Jacob to Florinda has

\footnotetext{
${ }^{35}$ In her definition of ocularcentrism Conor writes, "It is said to be the outcome of centuries of thinking in terms of seeing, a manner of thinking which gained dominance in antiquity. The material visibility of Greek gods, the provision of the spectacle in human action and drama, the idealization of the visual form in Greek art, the centrality of the eye in Greek mythological literature (such as the stories of Medusa, Narcissus, and Oedipus), and Greek mathematics emphasis on geometry all testify to an Hellenic affinity for the visible" (19).
} 
nothing to do with sex but is precisely what he can imagine about her thanks to the fact that she is dark, mysterious, and tragic-seeming.

Significantly for my argument our initial introduction to Florinda is book-ended by a discussion of the ancient Greeks, and occurs at a party where Jacob's head is wreathed in paper flowers. Here Jacob not only misreads Florinda's character and station but also reveals his knowledge as stemming from formal education in and acceptance of productive ideology: "She had called him Jacob without asking his leave. She had sat upon his knee. Thus did all good women in the days of the Greeks" (76). Florinda possesses both agency and authority in the story by virtue of the fact that she appears to be what she appears to be. Because Florinda's profession has not been revealed, she has not yet entered the masculine productive realm. "Florinda's story" is a story of seduction, and Jacob's sense of masculinity, indeed his belief in masculine ideology, is eluded by the fact that Florinda remains pure appearance. That Florinda is allowed a history at all, where Laurette is denied history, depends upon her seduction. At the same time, we are not aware of her real name: "As for Florinda's story, her name had been bestowed upon her by a painter who had wished to signify that the flower of her maidenhood is still unplucked" (77). Florinda, like Lorelei in Gentlemen Prefer Blondes, becomes the mirror of masculine desire. Both women allow themselves to take on an artificial name, ultimately playing with the meaning attributed to that name, in a way that allows them to negotiate a masculine productive society.

\footnotetext{
${ }^{36}$ Although grammatically awkward, I say "appears to be what she appears to be," not Florinda "is what she appears" as this logic is productive. "Is" designates a meaning, a truth, and I argue that Florinda does not yet have one.
} 
Florinda's early interaction with Jacob cannot be separated from this name any more than it can be separated from her insistence upon near-chastity. The fact that Florinda "talked more about virginity than most women do; and had lost it only the night before" suggests to Jacob not only that he has been her first sexual encounter, but also affirms his masculinity (77). Her possibly-pretended assertion of chastity, which strategically affirms Jacob's power allows her agency: within the space of just one paragraph, where there is never a full stop, Florinda "wept," "wander[ed]," "stood," “trailed," "opened," "powdered," "read," "detected," "accused," “declared," "found herself," "slowly saunter[s]," "liked" "drew off her gloves," and "told" (78). In no uncertain terms, Woolf tells her reader that this activity depends on her ability to seduce, rather than any outward display of sexuality or sexual agency: "Jacob took her word for it that she was chaste. She prattled, sitting by the fireside, of famous painters ... wild and frail and beautiful she looked, and thus the women of the Greeks were, Jacob thought; and himself a man and Florinda chaste" (78). Jacob's reference to Florinda's "prattling," her outward display of femininity, forestall any suspicion over the fact that Florinda entertains other men. Florinda is, for Jacob, incapable of guile, completely transparent, to the extent that he even "wondered whether she had a mind" (79). But Jacob can only assert the truth of masculine ideology as long as Florinda fulfills her feminine, seductive, role. As soon as the "truth" of Florinda's situation is brought to light, as soon as she enters the productive realm, through Jacob's realization that Florinda is a prostitute, she disappears from Jacob's life. Walking along the streets of London at night Jacob is finally made aware of his philosophical fallacy, and that masculine ideology is exposed as 
weakness: “Then he saw her turning up Greek street upon another man’s arm” (94). That Jacob recognizes the "truth" about Florinda on Greek street is more important than any actual infidelity. It is not just Florinda who has betrayed him, but the whole of masculine ideology. Exposed as a threat to Jacob's sense of masculinity, Florinda is, in the end, made to pay for her sexuality. The last time we meet her, she has undergone a change. She wears a "dull expression like an animal" (168). She is pregnant and Mother Stewart is "recommending remedies, consulting friends," suggesting that abortion is her only option (168).

Even though the masculine ideology of ocularcentrism is exposed for its weakness and its ability to be overturned through feminine seduction, it is so engrained in society that seduction continues to emasculate Jacob over and over again. Jacob never seems completely cognizant of the fact that his ideology fails. He keeps applying productive ideology to all of the women that he comes in contact with, the last of them, the wealthy, married Sandra Wentworth Williams, whom he ironically meets in Athens. Although the failure of productive ideology is reinforced over and over again in the novel, possibly even leading to Jacob's death in the end, he is never able to recognize that a strategy of resistance exists. The ultimate example of this emerges in the scene where Jacob is standing among the ruins of ancient statues in Greece: "These statues annulled things so! He stared at them, then turned, and there was Madame Lucien Grave perched on a block of marble with her Kodak pointed at his head. Of course, she jumped down, in spite of her age, her figure ... She jumped down, but not before Jacob had seen her ... 'Damn these women - damn these women!' he thought ... 'How they spoil things,' he 
murmured" (151). Armed with her Kodak camera, a metaphor for the power of seeing during the early twentieth century, Madam Grave is present in a place where she should not be, and not only that, she is completely unaccompanied. The fact that her camera is pointed at Jacob also suggests her ability to do battle with him, to metaphorically shoot him and capture him. It is the society of the spectacle, together with the tactic of seduction, which allowed women the ability to negotiate social space, to compete with men in the public realm, and to challenge the production of masculine ideology in the modernist era.

The problem that many feminists have in relation to women of the modernist era is closely linked to their political inactivity. That is, many of these women failed to rise up, to vote, to become a strong enough opposing political force after suffrage: Estelle Freedman writes, “Women in the 1920's began to be presented as flappers, more concerned with clothing and sex than with politics. Women had, by choice... rejected political emancipation and found sexual freedom" (379). Feminists have looked for other arenas in which women were politically active, turning precisely to the sexuality of the "new woman," "the clothing and sex," and the pervasive presence of sexual reform as possible alternatives. The problem with this desire to pinpoint alternative sources for female power is they continue to depend on masculine ideology to set the standard by which women should and can exert power rather than looking at the ways in which women might challenge masculine ideology by refusing to conform to its ultimately oppressive structure. Perhaps all that is required to see the "new women" as politically active is a small shift in focus away from the "new women" being characterized as 
sexually liberated. In the texts discussed here and many others, women who oppose masculinity in modernist era literature do not succeed, suggesting not only that there were still many roadblocks to sexual liberation and equality, but these women apparently did not need to conform to the ideology of sex as empowering. Power, for women in the ' 20 s, had a different emphasis, which worked quite well for film actresses and public ballroom dancers like Irene Castle, affording them the authority necessary to have an important influence on the roles of women in society. To seduce masculinity was clearly a way to gain social mobility and public authority in the modernist era. A switch in focus from women as sexual to women as agents of seduction opens the door to relatively unexplored levels of authority and agency. 


\section{CHAPTER FIVE}

\section{POST-WAR FEMINISM: AN INTERLUDE}

In the previous chapter I argued that feminism in the modernist era should be divorced from the ideology of sexual liberation because proclaiming the new woman's sexual subjectivity not only reinforces what I have been calling the political backslash but also strengthens oppressive masculine ideology regarding the social value of sex. In an effort to challenge and overturn productivist logic of sex, I argued that the new woman's agency and authority is better theorized in terms of seduction, a theory of the feminine which overturns the subject/object divide governing the laws of sexuality through artifice and the spectacle. What remains at issue, of course, is a lingering historical narrative in which women's agency in the modernist era is short lived. History and scholarship would have us believe that, after the Second World War, feminism virtually disappeared along with the new woman and her public agency.

Save for the publication of Simone de Beauvoir's The Second Sex (1953) (which didn't gain popularity until the 1970 s), the 1940 s to the early 60 s constitute a gap in feminist scholarship, as language of "equality" and "liberation" fade into terms like "nuclear family," "suburban expansion," and "the happy housewife." Many feminist scholars reinforce the same narrative when imagining women of the post-war period: "Upon the return of servicemen to civilian life at the end of World War II, a host of 
public and private agencies pressured many women to abandon their wartime employments ... and readjust to the roles of housewives and mothers" (Ryan 77). While in these narratives women no longer have the freedom to work outside the home, they also are not contributing to the social value of productive labor. In "“I Was Appalled': Invisible Antecedents of Second Wave Feminism” (2002), Linda K. Kerber tries to account for the master narrative that overshadows and prohibits discussion of the 1950s and feminism: "Why do most people think that the feminist agenda did not emerge until 1969 or 1970 ? Because McCarthyism and Cold War anxieties muffled or silenced the voices that were outlining that agenda" (97). It is not so much that feminism did not exist in the early post-war period as it is that productive masculine ideology about warfare and the social value of democracy takes precedence. Women are represented in ways that reinforce a different social value: the "happy housewife" reinforces national health and wellbeing. It isn't until the publication of The Feminine Mystique (1963) that feminist epistemology allows Betty Friedan to break the silence in a way that suggests women of the 60 s are right back where they started from in 1890 . Simulating the productive politics of Charlotte Perkin's Gilman's Woman and Economics (1898), Friedan encourages women to leave the house and find work. The difference between Friedan and Gilman, of course, is that Friedan does not argue that domestic women are "parasites" or drains on society. For Friedan, it is the confines of the home and the 2.5 children that are killing women's spirits. Donna Reed's cookie-cutter smile is a lie.

While I do not want to focus extensively on 1940s and 50s feminism in this dissertation - indeed the dearth of feminist scholarship prohibits me from doing so - my 
hope is that a theory of seduction will allow scholars to reclaim this time period for feminism in a way that does not take stock in familiar productive binaries upon which many feminists and historians rely: subject/object, public/private, active/passive, masculine/feminine, real/artificial. For as Baudrillard states, quite rightly:

All that we have been asked to believe, the universal discourse on inequality between the sexes - the universal discourse on equality between the sexes, the theme song of egalitarian and revolutionary modernity ... is perhaps one giant misunderstanding. The opposite hypothesis is just as plausible and, from a certain perspective, more interesting - that is that the feminine has never been dominated, but has always been dominant. (14)

The post-war period need not be tossed onto the political dung heap of feminist history once contemporary feminists begin to challenge masculine productive ideology. A theory of seduction allows feminism of the modernist era to be seen as continuous with post-war feminism rather than as ephemeral.

Such a project would entail seductive readings of women like Cosmopolitan editor and author Helen Gurly Brown; domestic housewife humor writer Shirley Jackson, author of Life Among the Savages (1953); and Jean Kerr, author of novel turned Hollywood film Please Don't Eat the Daisies (1957). We should begin with these writers precisely because Betty Freidan openly criticizes them for taking a very serious problem (the exploitation of housewives) and laughing about it in their fiction:

There is something about Housewife Writers that isn't funny-like Uncle Tom, or Amos and Andy. 'Laugh,' the Housewife Writers tell the real housewife, 'if you are feeling desperate, empty, bored, trapped in the bedmaking, chauffeuring and dishwashing details. Isn't it funny? We're all in the same trap.' Do real housewives then dissipate in laughter their dreams and their sense of desperation? Do they think their frustrated abilities and their limited lives are a joke? Shirley Jackson makes the beds, loves and laughs at her son-and writes another book. Jean Kerr's plays are produced on Broadway. The joke is not on them. (57) 
Unlike our seductive feminists Joan Rivière, Virginia Woolf, Lucy Irigaray, Hélène

Cixous, and Judith Butler, - all discussed in chapter one - Betty Freidan sees laughter as

a perpetuation of injustice rather than as a challenge to productive meaning making

systems. ${ }^{1}$ For Friedan, the role of a housewife is inherently unjust. Friedan never

challenges the ideology that informs her reading of domestic life, or questions the ways

in which she belittles the lives of so many women who do not conform to the value of

masculine ideology: the very ideology that supports domestic lives as "limited,"

"frustrated," and desperate. While Friedan claims that these domestic humor writers are reinforcing women's exploitation, their crime is actually much more dangerous: they do not reinforce the social value of production.

Seeing the post-war period as a politically inactive time period for feminism leads to the belief that Betty Friedan is the only significant feminist writing during this time. ${ }^{2}$ And while the publication of Jennifer Scanlon's Bad Girls Go Everywhere: The Life of Helen Gurly Brown (2009), gave immediacy to what I was already thinking about how Baudrillard's theory of seduction might prove valuable to our conception about what

\footnotetext{
${ }^{1}$ In Simulacra and Simulation, Baudrillard writes, "Why does one laugh? One only laughs at the figure of reversibility of things ... it is because the stake is always reversible between masculine and feminine, between life and death, that one laughs" (145). This quotation helps when trying to understand why laughter is such a crucial theme in feminist literature. Laughter refuses to acknowledge both the "reality" and the "truth" of productive discourse. In refusing to uphold the value of masculine discourse, feminism challenges masculine ideology or the belief that woman are oppressed.

${ }^{2}$ Kim Tofoletti's work on Barbie dolls (brought into existence in the late 1950s and often used as an icon for women of that time period) is also helpful in facilitating such a revisionist project. Cyborgs and Barbie Dolls (2007) argues that the Barbie doll is an early example of the post-human, a theory in which the subject and the object are no longer distinct and binary but rather co-exist.
} 
constitutes feminism, particularly in the post-war period, public reaction to Scanlon's biography helps to underscore my argument about the pitfalls of productive feminism. In a recent New York Times (April 26, 2009) review of Bad Girls, Ginia Bellafante rebukes Scanlon's attempt to place Gurly Brown on equal footing with the likes of Betty Freidan whose efforts (along with that of second-wave feminism) are "nobler" than that of the "apolitical" and "anhedonic" writings of Gurly Brown. Yet, Scanlon's biography has sparked a chain of new attention to the former editor-in-chief at Cosmopolitan magazine, including a recent article in The New Yorker entitled "Helenism: The Birth of the Cosmo Girl" (April 11, 2009) by Judith Thurman. Unlike Bellafante, Thurman is "happy to see Brown getting her due as a pioneer of libidinal equality." But Thurman similarly warns her readers against taking Gurly Brown too seriously. Indeed the fault she finds with Bad Girls is what Thurman argues is Scanlon's desire to "seek a moral in the glittering life of a bad girl." Thurman assumes a discord between Scanlon's "savant" discussion of second and third-wave feminism, and the vision of Brown as a pioneer who bridges the gap between these more serious minded approaches. As Thurman sees it, Gurly Brown does not require, deserve, or evoke such serious-mindedness. Gurly Brown was, quite simply, "a classic poor girl on the make, lusty and driven." Feminism's exclusion and devaluation of Gurly Brown is a concern at the heart of Scanlon's biography - and it appears that her text has not had the desired effect. At best, Gurly Brown remains "feminist" to the extent that Sex and the City's Carrie Bradshaw and her often-cited predecessor Lorelei Lee from Gentlemen Prefer Blondes are "feminist." She is shamelessly materialistic and selfsufficient, worthy enough to be our girlfriend but not our mentor. Or, more disastrously, 
according to Bellafante, Helen Gurly Brown is about as worthy to be labeled "feminist" as 2009 vice-president political hopeful Sarah Palin. She's a neophyte, a dilettante.

My very serious question is: why should feminists not consider Gurly Brown seriously? Contrary to Thurman's argument that Jennifer Scanlon is searching for "morals," Scanlon is really quite frank about the reasons why feminists have historically rejected Gurly Brown, or about why she qualifies as a "bad girl."3 Gurly Brown is a selfproclaimed feminist, a capitalist, and a pick-yourself-up-by-the-bootstraps individualist. She did not go to college. She is from a lower-class background. She speaks the language of single working-class women about how to get ahead, and she is unapologetic in her endorsement of femininity and the beauty regiment. Gurly Brown argues that women should work the system rather than fight it, is happy when Cosmopolitan is accused of turning women into sexual objects ("I say bravo!"), and refuses to argue the evils of women's victimization (Scanlon 174). In Sex and the Single Girl, Gurly Brown argues that single women, when strapped for cash, should absolutely accept (indeed expect) monetary assistance from men, and urges single women to have affairs with married men. In short, Gurly Brown threatens to undo all of the serious work feminists undertake. If we believe the reviews above, Gloria Steinem was right when she argued in 1960 that Gurly Brown is a victim of patriarchy (albeit an extremely successful and wealthy victim).

Although Jennifer Scanlon may have failed to elicit a feminist reaction that differs from Gloria Steinem's early dismissal, it is not entirely her fault (though, as a book by a

\footnotetext{
${ }^{3}$ This label has been applied to Jane Gallop, among other academic feminists.
} 
popular press, many arguments made against Gurly Brown go under-theorized). As Scanlon (all too subtly) explains in Bad Girls Go Everywhere, good feminists, complex feminists, serious feminists, upper-class, educated feminists prefer arguments that espouse the same values and ideologies as white intellectual males. As Baudrillard explains in Seduction, "there is a strange, fierce complicity between the feminist movement and the order of truth" (8). Feminism too often accepts the value of "reality" rather than challenging it. Scanlon provides an example of this complicity in her discussion of Friedan's canonical feminist text The Feminine Mystique. This groundbreaking work serves to articulate the truth in masculine ideology, which argues that domestic spaces are inferior to public spaces by nature of the fact that they are feminine. Women must, according to Friedan's argument, reject femininity as it denies them their identity as human beings, denies them their autonomy, and infantilizes them. Women are victims, prisoners in the home, and must find ways to free themselves from domestic responsibilities. Those women who claim to get any pleasure in the home are, according to Friedan, suffering from false consciousness. Thus, feminists and happy housewives came to be seen as opposing positions. ${ }^{4}$ Scanlon astutely points out that Friedan does not consider alternatives to masculine discourse when asserting the inferiority of women's home lives, even as her contemporary Julia Child frequently articulates the joys and art of cooking as creative outlet for the "servantless American

\footnotetext{
${ }^{4}$ I would argue that these early oppositions set up between women by feminists like Freidan are partially responsible for feminism's "bad" reputation. Confronting negative assumptions takes up much of our work, as evidenced by entire works dedicated to expelling myths of tyranny, and defending feminism as necessary. See, for example, Jessica Valenti's, Full Frontal Feminism: A Young Woman's Guide to Why Feminism Matters (2007), or bell hook's Feminism is for Everybody: Passionate Politics (2000).
} 
cook." But Mastering the Art of French Cooking (1961) is only slightly more likely to enter the feminist canon than Gurly Brown's Sex and The Single Girl. Coincidentally, neither of these authors espouses the view that femininity or women are inferior to men, or that to liberate women feminism must go in the direction of the system that defines femininity as such. Oddly enough, "liberation" under the terms dictated by men reads a lot like homogenization.

Because feminists in the contemporary media have shown a preference for a productive model of feminism as exemplified by Betty Freidan, feminism in the popular press exposes an alliance with production and productivity as the means to incorporate women into the political economy of men. To provide space for a challenge to productive morality, the value of masculine truth claims, would be to allow for a greater number of influential women to be included in the feminist canon: women who do not subscribe to the innocence or the victimization of women (we are partially responsible), women who suggest, like Gurly Brown, ways to play with the system rather than supporting it or opposing it (insofar as opposition is also a part of that system). Can we not infer irony from Gurly Brown’s “bravo?” Can we not, like Liz Conor in The Spectacular Modern Woman, see women who objectify themselves as posing a challenge to the ideology of the object status? In an example of non-productive (or seductive) feminism, Gurly Brown describes the agency of the single woman, while simultaneously refusing to engage in the productive morality of both meaning and value.

Sex, of course, is more than the act of coitus. It begins with that delicious feeling of attraction between two people. It may never go further, but sex it is. And a single woman may promote the attraction, bask in the sensation, drink it like wine, and pour it over her like blossoms, with never 
a guilty twinge. She can promise with a look, a touch, a letter or a kiss and she doesn't have to deliver. She can be maddeningly hypocritical, and after arousing desire, insist that it be shut off by stating that she wants to be chaste for the man she marries. Her pursuer may strangle her with his necktie but he can't argue with her. (7)

What Gurly Brown defines as sex looks more like the traditional definition of seduction, often seen as immoral and self-serving, but her insistence upon using the term "sex" destabilizes sex as a masculine system of meaning making and value. From the ironic "of course" (you didn't know?), to the suggestion that sex is a means to another means with no end, Gurly Brown shows how the system can be used to the advantage of the single woman, whereby women are allowed complete control over their sexual relationships. Masculine ideology can call this woman hypocritical, but that is in itself a hypocritical move. For within a contradictory structure, how can a woman avoid being hypocritical? Gurly Brown takes the derogatory term "hypocritical" ascribed to single women, and relocates the offence to indict the gender structure itself.

For Gurly Brown sex and sexuality are not so much about playing by the rules as playing with the rules. The man with the necktie becomes the productive figure in Gurly Brown's prose. He is knowable. We can anticipate his anger and can predict his violence, but he cannot deny that he is responsible for the structure used to torture him. Thus, for Gurly Brown, productive rationality is that which leads to violence in the first place. The "necktie's" assurance in the power of his deductive reasoning and knowledge has failed him: he does not know if the woman will engage in coitus -- but somehow she is already engaging him in sex. The irony here is that "sex" may or may not be coitus, but it may also be the biological term "sex" as "female" or "feminine." Thus a woman engaging in 
sex is performing femininity. If, as many feminists suggest, a woman's inferior status is dependent upon the fact that she be unknowable, undefinable, unclassifiable, and controllable as female then Brown certainly turns this inferiority on its head. Because the single woman's role is ambiguous, she finds agency in the very ambiguity of her position.

To allow women like Gurly Brown into the feminist canon would be to imagine a place for feminism that resides outside of the productive system, which contemporary feminists like Eve Sedgwick find difficult to change. ${ }^{5}$ Feminism that focuses on the dissemination rather than the perpetuation of information about women poses a radical challenge to productive ideology. And this is where Jean Baudrillard's theory can be beneficial to post-war feminism because the challenge is not to incorporate feminism into the productive model. Rather, the challenge is to disseminate the productive model - not through opposition, but in finding the fissures that underscore the weakness of productive discourse, and to use these discourses for feminist purposes while being careful not to slip into legitimating the "truth" of that discourse.

Fortunately, and thanks in large part to present day nostalgia for the 1950s and 60s in popular culture, work on feminism of the post-war period is occurring if only by nature of the fact that once disregarded figures from the 1950s are finally being discussed in feminist discourse. For example, in “'Is It Ridiculous for me to Say I Want to Write?”

\footnotetext{
${ }^{5}$ In Between Men: English Literature and Male Homosocial Desire, Sedgwick expresses concern over the fact that radical feminism, espousing non-historical structuralist discourse, effectively ends up reproducing power structures rather than changing them. Citing Jane Gallop's Daughter of Seduction as one such example, Sedgwick argues, "historical change from this point of view appears as something outside the structure and threatening - or worse, not threatening - to it ... [Radical Feminism] can make future change appear impossible ... even though desirable" (13).
} 
Domestic Humor and Redefining the 1950s Housewife Writer in Fan Mail to Shirley Jackson” (2009), Jessamyn Neuhaus argues that “fans of Jackson’s writing clearly believed that the figure of the housewife writer offered them an opportunity for extending and even challenging those domestic ideals by becoming writers themselves, and perhaps joining a community of women beginning to question those limitations" (122). Although a theory of seduction would foreground a challenge to masculine ideology as necessary to understanding the social devaluation of domestic roles, reinforcing the ways in which productive ideology underscores the importance of the masculine over the feminine, acknowledging Shirley Jackson as an important feminist figure is certainly an important step toward recognizing seductive feminism in the post-war period. 


\section{CHAPTER SIX}

\section{SIMULATING FEMINISM:}

\section{POSTMODERN POLITICS AND THE LANGUAGE OF SILENCE}

In the preceding chapters, I have historicized Baudrillard's critique of production in ways that highlight particular moments in feminist writing and theory. I have focused on the importance of labor that rallied feminists of the progressive era and the social value of sex that ignited the writing of feminists of the modernist era, and I have shown the ways in which these particular ideologies perpetuate a system of production historically used to oppress women and minorities who do not conform. I have shown the ways in which some feminist writing from these periods uses a strategy of seduction to pose a radical challenge to the authority of that system. Through close readings of selected feminists texts, I offer a reading practice that foregrounds seduction, the ways in which artifice and the absurd trump logic and reason. Seduction challenges the productive imperative to create meaning and its inevitable reinforcement of power. However, in addressing feminism of the postmodern era I must also address an important historical shift that influences postmodern feminist writing and theory. In much the same way that a theory of postmodernism tries to define its distinctness from that of modernism, so too does feminism of the postmodern era try to distinguish itself from feminism of the modernist era. In the first part of this chapter I address the ways in which feminism of the postmodern era is historically conceived in terms of the shift from an 
ideology of equality to that of difference. I argue, along with Rita Felski, that thinking in these terms does not allow us to get outside of oppressive structures but brings us into their very heart. I suggest, along with Baudrillard and Haraway, that the postmodern era marks a shift from the productive model for power to an era of simulation. In the postmodern era, feminists came to relinquish earlier productive models realizing the ethnocentrism of claims to speak for all women (e.g., modern arguments for equality and universality); yet postmodern feminists get bogged down in arguments over equality/difference or poststructuralist/materialist analyses, missing the important historical shift Baudrillard identifies as the shift from production to simulation. Many feminists keep arguing as if there were a "real" rather than simulations of reality. Much as a theory of seduction is resisted by some feminists because they think it endorses a view of women as artificial as opposed to genuine, so too simulation is resisted in the name of some "real," missing the point that the model is all there is.

According to feminist history, the 1970s ushered in a shift in feminist writing. History tells us (please stop me if you've heard this one) that feminism dating back as far as Mary Wollstonecraft conceived of female power using an equality model for feminist writing and politics. The particular argument used by feminism during this long time period stressed not only that women were equal to men but also that women should be treated as the social equals of men. Women should be allowed the same access to education, politics, and labor. This model takes the lives of men as the zero degree from which equality should be measured. In this dissertation I have shown the ways in which the philosophical tenets of these early feminists are based on a masculine, 
productive imperative. Feminism of the postmodern era, on the other hand, is structured by the model of sexual difference, a model generally conceived in terms of binary oppositions that, depending on who you read, are given different names. In Sexual/Textual Politics (1985) Toil Moi refers to these models as themselves opposed: as "radical" French and "liberal" American feminism. In Between Men: English Literature and Male Homosocial Desire (1985), Eve Sedgwick refers to two further postwar models: those of "Radical Feminism" and "Marxist Feminism." In Doing Time: Feminist Theory and Postmodern Culture (2000), Rita Felski refers to the models as "second wave" and "post-structuralist" feminism. Whatever the models and whatever the names feminists call these models, they are usually referring to either a theoretical focus on the feminine difference versus the masculine or a focus on the material (read "real") differences between women and men. Whatever the methodological differences among postmodern era feminisms, difference is the key term. Despite the fact that few feminists fall firmly on either side of these two poles, their models are still largely viewed as incompatible, warring approaches.

These warring feminist models have become so commonplace in feminist discourse that it is now possible to anticipate arguments and rebuttals on all sides of the debates. Materialist feminism, for example, argues that theoretical feminism valorizes femininity, does not engage in practical politics, focuses narrowly on language games, and assumes a universal category for women that does not take into account racial and class differences. Theoretical feminism generally argues that materialist feminism assumes all women are oppressed, cannot imagine structural change, and assumes 
"reality" as objective and unmediated. Such feminist critics tend to point out two glaring issues when critiquing each other's work: arguments of contradiction and arguments of essentialism. But rarely do such feminists question the ways in which invoking the ideology of difference perpetuates both essentialism and contradiction because these models are bound up in the process of power. ${ }^{1}$ Contradiction is too often used in feminist discourse as a way to dismiss a theory or theorist altogether. Refusing to give our proverbial guinea based on the fear that we will be discovered to be contradictory becomes a political deterrent. Censoring discourse to avoid essentialism is in itself an essentialist and contradictory move. While it is impossible to completely stave off essentialism and contradiction, the idea that this should be the aim or the goal of feminism is ultimately tied to the belief that "reality" can be accurately represented. The obsession with trying to make arguments without contradiction and essentialism has taken up too much of feminist writing in the postmodern era. ${ }^{2}$

In Doing Time, Felski argues that equality and difference cannot figure into postmodern feminist discourse unproblematically. In structuring feminism according to the dichotomy between equality and difference, Felski says that we must first recognize that the opposite of equality is not difference; it is inequality. Similarly, the opposite of difference is not equality but identity. In feminism of the postmodern era, the notion of

\footnotetext{
${ }^{1}$ For example, Felski writes, "I confess to being particularly irritated by tables that draw up oppositions between the modern (hierarchy, reason, identity, depth) and the postmodern (anarchy, desire, difference, surface) while claiming in the same breath that postmodernism overcomes dualistic thinking" (204).

${ }^{2}$ For example, see Diana Fuss's Essentially Speaking: Feminism, Nature, and Difference (1989), which spends 144 pages arguing that constructionist thinking can be just as essentialist as thinking in terms of essences.
} 
difference is essentially (literally and figuratively) used to argue for a larger

understanding of equality. What feminist ever promoted a politics of inequality? There is, thus, no radical break between equality feminism (in the modernist era) and difference feminism (in the postmodern era). Moreover, according to Felski, thinking in terms of equality and difference does not radically alter our ways of thinking:

To defend the value of difference and specificity is to call up some universal maxim, such as the rule that 'all differences should be treated with respect.' It is soon clear, however, that this minimal norm does not get us very far. What differences are we talking about? Those of gender, race, class, sexuality, education, age, intelligence, opinion, politics, lifestyle? Are all these differences equal? For example, can the Ku Klux Klan's desire to express its political differences from mainstream values be reconciled with the desires of specific racial groups to have their own cultural differences respected? The appeal to difference, it soon becomes clear, does not lead us out of the labyrinth of norms, values, and truth claims, but takes us into its very heart. (130)

Felski's point here is that, in setting up terms of difference, there will always be a hierarchy. But, too, in speaking purely about difference, we will necessarily regurgitate earlier feminist claims of sameness: all people are created equal in their very difference. We have, it seems, come full circle back to early egalitarian feminism; we have returned to thinking in terms of the inherent sameness of women - even if by the measure of their difference. Another problem here is that, although the concept of identity (sameness/difference) was relevant to the origins of feminism, it is less relevant today. We can no longer-if we ever really could - talk about sameness and difference as if these categories could possibly exist outside the power structure that created them.

The problems with structuring feminism around the ideology of difference are manifold. Difference is part of a dichotomy. Difference assumes identity. Nor are all 
differences are created equal. Meanwhile, in arguing for difference feminists cannot help but perpetuate the particular norms that they would like to critique. There is no different difference. Difference, like subjectivity, is an overdetermined portmanteau in feminism and one that ceases to move beyond old ways of thinking based on the dichotomy between identity and difference. As Simone de Beauvoir states, "Now, after centuries of men constantly repeating that we were different, here are woman screaming, as if they were afraid of not being heard and as if it were an exciting discovery: 'We are different!' Are you going fishing? No, I am going fishing" (qtd in "Difference: A Special Third World Woman's Issue” 19).

While many feminists, including Felski, see the postmodern era as governed by the ideology of difference, ${ }^{3}$ Baudrillard argues that what distinguishes the social structure of the modernist era from that of the postmodern is the shift from conceptualizing a productive society governed by the perpetuation of social value to conceiving a social structure governed by the simulation of reality. In defining what he means by simulation, Baudrillard writes, "Simulation is no longer that of a territory, a referential being or a substance. It is the generation by models of a real without origin or reality: a hyperreal. The territory no longer precedes the map, nor does it survive it" (Simulacra and Simulation 1). The social structure of production, as exemplified by the modernist obsession with identifying, categorizing, and ordering, is particularly interested in the affirmation of social value and is dependent on the social reinforcement of these values

\footnotetext{
${ }^{3}$ Felski writes, "Postmodernism simply is the culture of difference, freeing us from the tyranny of a single, universal time" (2).
} 
through speech and writing. A social structure of simulation, on the other hand, asks

for no such social response because the values are embedded in the medium. Simply put, where a productive society is governed by the repression of speech, a society of simulation is reliant on the perpetuation of speech.

In Simulacra and Simulation (1994) Baudrillard defines simulation as:

characterized by the precession of the model, of all the models based on the merest fact - the models come first, their circulation, orbital like that of a bomb, constitutes the general magnetic field of the event. The facts no longer have a specific trajectory, they are born at the intersection of models, a single fact can be engendered by all the models at once. (16-17)

In "The Masses: The Implosion of the Social in the Media" (1985), Baudrillard offers the opinion poll as an example of simulation. The opinion poll, according to Baudrillard, is said to manipulate both need and consumption. However, the level of uncertainty that surrounds the results of an opinion poll underscores the impossibility of articulating either public opinion or individual will. The opinion poll does not represent the public opinion; rather it stages opinion. We cannot be sure of its influence, which in turn creates uncertainty about reality. Whereas a productive society is interested in imparting knowledge and truth claims, a society of simulation is interested in the articulation of reality, norms, and facts, making no move to either inform or produce a response: the medium becomes the message. Baudrillard does not recognize even the shift from production to simulation as a definitive shift, as in the claim that production is gone and we live only in a world of simulation, but argues rather that these power structures exist simultaneously and their incongruity causes uncertainty: "It is this lack of relationship between the two systems which today plunges us into a state of stupor ... a radical 
uncertainty as to our own desire, our own choice, our own opinion, our own will”

(579). Baudrillard argues that simulation is similar to seduction in that they are both forms of game play. But Baudrillard terms simulation "cold" because it does not ask for a response from those it claims to represent and is irreversable. As I have been arguing, seduction constitutes a duel/ dual relationship with production, whereas simulation is a one-way street (subjects without objects, needing no response). Challenging the simulation of reality requires not response - but non-response (to which I will return later).

\section{Modeling Feminism}

We need a way to organize feminist history that takes into account the historical shift from the modernist-era social structure of production (equality/difference) to the postmodern social structure of simulation (norms and models). I argue that what characterizes feminism of the postmodern era (1970s-1990s) as distinct from that of the modernist era is not simply a question of difference. The 1970s also ushers in a method of feminist investigation that is obsessed with the implementation of models for thinking about women and reality. Feminism is no longer simply a question of social value. Not only do we have the epistemological model of equality/difference that frames feminism according to historical categories, we are introduced as well to a model for thinking about feminism in terms of waves: first wave, second wave, and third wave. In 1970, Shulamith Firestone writes that at the moment of her writing, "It is the second wave of the most important revolution in history" (15). Beginning with Firestone, feminism separates and divides according to models for reality. What starts out as "radical feminists," 
“conservative feminists," "politicos," "ladies auxiliary on the left" (32-33) in the 1970s, quickly morphs into radical, materialist, psychoanalytic, poststructuralist, postcolonial, and deconstructive feminists (to name but a few) in the 1980s and 1990s. Feminists of the postmodern era must, first and foremost, identify the particular model that frames their writing and politics.

We no longer, like psychologist Ernst Jones, whom I discussed in chapter two, need to classify and collect evidence about women in order to reinforce dominant social values. The value is embedded as a norm in the ideological models we use. While this is most assuredly an exciting time for feminism and feminist theory, ${ }^{4}$ problems necessarily arise when a model is used to describe the "real" conditions of women. The simulation of politics, when engaged in outside of the representation of reality - as practice or as a strategy used to throw a wrench in ideological systems of power - can be fun, ironic, and playful and yet still maintain deadly seriousness, a level of threat to the current structure for social power (as Donna Haraway, Jane Gallop, and Eve Sedgwick show). However, when these strategies for resistance are turned into models for representation, as simulations of the "real" lives of women, Western feminism becomes charged with ethnocentrism.

Perhaps the clearest articulation of the shift in feminism can be seen in Mary Daly's book GYN/ECOLOGY: The Metaethics of Radical Feminism (1978). Daly's text, in which she discusses four instances of women's oppression - suttee, footbinding,

${ }^{4}$ Donna Haraway is indeed jazzed by the possibility of a simulated politics (as opposed to a politics that engages the real, in feminism), "The cyborg simulates politics, a much more potent field of operations" (163). 
genital mutilation, and witchcraft - was originally criticized by Audre Lord, Gayatri

Spivak, and Chandra Mohanty (among many others) for "[obliterating] the differences, complexities and heterogeneities of the lives of, for example, women of different classes, religions and nations" (“Under Western Eyes" 84). However, such critique assumes that the problem lies only with the question of difference. While these criticisms provide evidence of the historical shift in feminism of the postmodern era, they tend to rely too heavily on critiques of essentialism and contradiction. Many of these critiques assume that there is a reality of women to uncover if only differences are taken into account, rarely critiquing the use of reality and difference as norms, or as legitimate models of feminist investigation. For example, Chandra Mohanty writes:

As Audre Lorde pointed out, women in Africa share a long tradition of healers and goddesses that perhaps binds them together more appropriately than their victim status. However, both Daly and Lorde fall prey to universalistic assumptions about 'African women' (both negative and positive). What matters is the complex, historical range of power differences, commonalities and resistances that exist among women in Africa which construct African women as 'subjects' of their own politics. (84)

Mohanty claims not only that Daly and Lorde are essentialist in their respective negativism and positivism, but also that there is a need for more particulars, more realities as sights of resistance to power. There remains an assumption that reality can be discovered, that 'real' women can be ethically represented through scholarship, and that the aim should be the Western empowerment of an under-represented section of women. Taking into account the differences among women does not question the reality principle or the models that feminists use for speaking about women. By refusing to question the 
model that Daly uses in her investigation, many feminists perpetuate these models and thus perpetuate the very outcomes that they would like to attack as essentialist.

The issue at hand is actually much more complicated and needs to be addressed in terms of Daly's simulation of women's realities in order, in turn, to address issues that continue to appear after Daly's writing. Feminist modes of investigation make a subtle shift from the articulation of "truth" under the productive structure to "reality" under the structure of simulation. Whereas feminists discussed in previous chapters such as Charlotte Perkins Gilman and Margaret Sanger argued that women could be as socially valuable as men by adopting masculine ideology (claiming that the greatest of all social values is the labor one performs and the material one produces), feminists at the beginning of the postmodern era, like Mary Daly, use normative models for speaking about women's reality. Daly refers to her particular model as the Sado-Ritual. The shift that she announces quite clearly articulates the shift that I have been referring to. Daly argued that all of the Western historical and anthropological scholarship on the topics of women and history hide the atrocities against women in favor of speaking "objectively": "The bland rituals of patriarchal scholarship perpetuate the legitimation of female sacrifice. The social reality, unacknowledged by such myth-masters, is that of minds and bodies mutilated by degradation" (119). That is, according to Daly, scholarship on women, prior to her writing, used the productive method of disinterested knowledge or truth, which did not account for the actual lived realities of women. Truth is no longer deemed objective, for Daly, as investigation makes the scholarly masculine bias known. Reality, according to Daly, which she believes to be unmediated, becomes crucial to our 
understanding of the various conditions under which women operate. This shift from knowledge to reality is consistent with the shift Baudrillard recognizes in his shift from theorizing modernist production to postmodernist simulation. In Daly's discourse, patriarchal scholarship constitutes a disinterested "truth" about rituals of violence. However, in telling this truth, "patriarchal scholars" mask "reality" - the pain, the suffering, and the oppression that Daly hopes to correct through her model of investigation. Although Daly claims that her investigation is different because it articulates reality, her investigation, which claims to be more true than true, becomes evidence of what Baudrillard calls hyperreality, or the inability to separate truth from representation. The model that Daly uses constitutes a moment of simulation whereby the model is the message: she is not producing new knowledge about women but rather she is simulating women's realities. The model, the method of investigation, is what masks the fact that she cannot get to the reality of these women for whom she speaks.

Daly's Sado-Ritual model insists upon "oppression” as fundamental to thinking about women. Her model includes seven points, all of which are necessary, for discussing worldly atrocities against women. In all cases, what is most important for Daly is the model she used in her discussion as she places each "event" within that context. Daly's Sado-Ritual model includes: "obsession with purity," "a total erasure of responsibility," "gynocidal ritual practices [that] have an inherent tendency to 'catch on' and spread," "women ... as scapegoats and token torturers," "compulsive orderliness, obsessive repetitiveness, and fixation upon minute details, which divert attention from the horror," "behavior which at other times and places is unacceptable becomes acceptable," and 
"legitimation of the ritual by the rules of 'objective' scholarship" (131-133). In critiquing feminists like Daly, the issue is less the accuracy of what she says about women than the assumption that the model provides access to women's reality. That is, not one of these planks can offer us any information about women. They are, in a sense, removed from women. These planks either refer to the scholars who write about women or to the "patriarchal" societies that engender the atrocities acted out on women. In this way, even the model itself cannot be linked to the realities of women. In using this model to speak about women, we are, in effect, learning only about the model.

Speaking for women becomes deeply problematic after this historical moment when feminists are asked to recognize the ethnocentism that informs their research on women whom they cannot know and for whom they cannot speak. Many postmodern feminists expose anxiety about speaking, as is underscored in the titles of a variety of feminist texts, such as Luce Irigaray's When Our Lips Speak Together (1980), Gayatri Chakravorty Spivak's “Can the Subaltern Speak?” (1988), Elaine Showalter's edited collection Speaking of Gender (1989), Diana Fuss's Essentially Speaking: Feminism, Nature and Difference (1989), Linda Alcoff's “The Problem of Speaking for Others” (1992), and Judith Butler's Excitable Speech: The Politics of The Performative (1997). In failing to acknowledge that the issue is not just how to speak about or for women but the very models used to speak about woman's reality, some feminists perpetuate the problem.

In her article, "The Problem of Speaking for Others," Linda Alcoff addresses the oppression that occurs when feminists try to speak for women whom they cannot know. 
Alcoff's essay expresses concern over the fact that feminists, now that they are charged with ethnocentrism, will stop speaking. Her essay is interested in encouraging feminists to keep speaking, but to do so in a way that does not disempower those "others" that feminist speech claims to represent. Alcoff recognizes that speaking for others is always problematic within a certain structure: "The problem with speaking for others exists in the very structure of discursive practice, no matter its content, and therefore it is this structure itself that needs alteration" (23). She nevertheless articulates a structure for speaking about women's realities in her essay, four points which she articulates as necessary in an effort to mitigate the oppression that occurs when feminists speak for others. Alcoff writes, "In list form they may appear to resemble an algorithm, as if we could plug in an instance of speaking for and factor out an analysis and evaluation. However, they are meant only to suggest a list of the questions that should be asked concerning any such discursive practice" (24). The biggest problem that I see here is the suggestion that speaking should or could be plugged into an "algorithm," thus perpetuating a model for speaking about women, such that what becomes most important is the "algorithm" used to describe an event. I fail to see how this differs in any way from what Mary Daly did with her Sado -ritual model, plugging events into the model. Although Alcoff states that her algorithm is meant to raise questions, she does not ask questions, nor does she show the ways in which this model could raise questions. Moreover, within such a formulation, Alcoff admits that we cannot hope to formulate a different understanding of events than what we already have: "these are by no means original: they have been learned and practiced by many activists and theorists" (24). 
Alcoff admits that the process of speaking cannot imagine anything new about the lives of women. The process of speaking, it would appear, can only effectively regurgitate what we've already learned and practiced. The lack of originality in feminist speech is explained through what Baudrillard says about the age of simulation: "It is useless to dream of a revolution through content, useless to dream of a revolution through form, because the medium and the real are now a single nebula whose truth is indecipherable" (Simulacra and Simulation 83). Because Alcoff suggests that oppression occurs as a result of a discursive structure and yet nevertheless articulates a comparable discursive structure for speaking about reality, refusing to challenge the use of reality as a model for speaking, it is difficult to see how she can avoid the kind of oppression that she would like to get beyond.

Alcoff articulates her model through four points suggesting an increased adherence to norms for speaking: "The impetus to speak must be carefully analyzed and, in many cases (certainly for academics!), fought against;" "We must also interrogate the bearing of our location and context on what it is we are saying;" "Speaking should always carry with it an accountability and responsibility for what one says;" and, "In order to evaluate attempts to speak for others in particular instances, we need to analyze the probable or actual effects of the words on the discursive and material context .... we have to pay careful attention to the discursive arrangement in order to understand the full meaning of any given discursive event" (24-26). What is important for Alcoff seems to be the increase of information. Of equal and significant import is the meaning that is attached to an event. Because her model does not allow for the disruption of meaning, or the ways in 
which an event challenges our ability to make meaning, Alcoff actually strengthens the system of meaning that she admits has been the main problem in speaking for others: "The dangers of speaking for others result from the possibility of misrepresentation" (23).

Moreover, fighting against speaking in a structure by using a model for speaking entails a perpetuation of speaking into the void of the model: the particular method of investigation that includes the desire to "analyze," "interrogate," and "evaluate" "material context" so as to articulate a less oppressive reality. In effect, what Alcoff argues for is a further perpetuation of speech, an increase in methods of investigation and evaluation, a perpetuation of the very act that structures power systems of the postmodern era. She exposes a particular obsession with the medium over the message. In an era dependent on speech proliferation in order for power to function, it would appear that Alcoff is going in the direction of the system that perpetuates the disenfranchisement of social groups. Speech, it seems, can only reinforce the structure for speaking, through which feminists can only effectively learn about our own location and context, the effect of our own words, our own responsibility. Could such a model ever do anything other than perpetuate itself ad infinitum?

At the end of her essay, Alcoff suggests what is most important about feminist speech by posing the following question: "We must ask further questions about [speech's] effects, questions that amount to the following: will it enable the empowerment of oppressed peoples?" (29). How can an increase in discursive structures, and an increase in meaning, possibly enable the empowerment of an "oppressed" people, especially when these structures are primary in any investigation? Reading Alcoff's essay 
raises doubt about speech's ability to empower anyone at all. It would seem that speech only reinforces the structure for speaking. However, when the postmodern era is dependent upon the increase in speech and requires the perpetuation of said speech in order to function in accordance with models for power, we must locate a strategy to counter the perpetuation of speech in order to challenge models for reality. If what is most problematic about speech is the meaning attached to it, then would not it make sense to interest ourselves in the disruption of speech and thus the disruption of meaning?

\section{Feminism Beyond the Model}

In Baudrillard's Challenge: A Feminist Reading (2000), Victoria Grace

articulates her aim in writing about Baudrillard for feminism which is to help feminists come to understand the ways in which they rely on models for speaking about women without questioning their use. Grace writes:

The various trends of analysis woven throughout the chapters of this book present Baudrillard's challenge, which I perceive to be the requirement for a paradigm shift away from feminism's preoccupation (fascination?) with the structure of the subject/object dichotomy and with feminine subjectivity, toward an immediate engagement with contemporary simulation and the myriad of singularities that remain irreducible to codification, models, and simulation. (191)

Indeed, Grace's engagement with feminism involves feminist theorists who, in her readings, reinforce concepts of subjectivity without challenging the ideology that informs such terminology. She assumes that all feminists are preoccupied with dichotomies based on the sample that she has chosen. Without trying to undo the value and importance of Grace's work, I would simply like to recall Baudrillard's words in Simulations:

Both objects and information result already from a selection, a montage, from a point of view. They have already tested 'reality' and have asked the 
questions that 'answered back' to them ... you can do anything, all you have to do is approach the original from the right angle, at the right moment or mood that will render it the correct answer to the instantaneous test of instrument and its code. (121)

Seek a structure, a dichotomy, feminine subjectivity, and you will find it. There is plenty of evidence, of writing, which will answer these questions in the way that you desire. This is how simulation works: the increase in speech provides an increase in evidence for the model. The model proves the content. Thus it would make sense that the opposite argument is also true: there is the evidence of the paradigm shift, of an immediate feminist engagement with simulation. ${ }^{5}$ The way out of the code is here, if only we read for it.

${ }^{5}$ Consider, for example, Trinh T. Minh Ha's discussion of the Chinese New Year Parade in her essay "Difference: 'A Special Third World Women Issue."' Similar in effect to Baudrillard's discussion of Disneyland, the Chinese New Year parade does not pretend to be a "real" space of Chinese identity (because the parade draws thousands of white tourists to Chinatown whereby Chinese identity becomes consumable and digestible). However, the parade saves the reality principle because it functions as a celebration of some real monolithic Chinese identity, which leads Trinh to ask the question "'Backhome' - whose spirit this parade pretends to perpetuate - did the Chinese celebrate their New Year squeezed up along the side walks with several dozen of hefty policemen?" (20, original italics). According to Trinh, Chinese identity is rendered impossible by the structure of the parade, because of the presence of (white and Chinese) policemen who are there "to guard (what is supposed to be) their parade, shoo them, push them back, or call them to order if they happen to get off the line while watching the procession" (20, original italics). Trinh's story functions, simultaneously, on a metaphorical and a literal level. Literally, there is no Chinese identity perceptible in the form of the parade (tiny cobble-stone streets, and white policemen). It is a celebration of identity that does not ask for, indeed forbids, a response from those the parade claims to represent. Metaphorically, the "police" come to signify Western philosophers and (to the extent that we are complicit) Western feminists. Western philosophy regulates and maintains the boundaries of what is and what is not considered identity (or identities), policing those boundaries, and keeping identities in line. We sit high on a horse and oversee, preserve, and protect the concept of identity as if it were an expression of the "real." 
In Doing Time (2000), Felski argues, "One of Baudrillard's most intriguing insights is that power works not through silencing and prohibition but rather through the proliferation and excess of communication" (139). While Felski admits to being intrigued by Baudrillard's insight, she does not explain how feminists might go about disrupting power, how we might use a reading or a writing practice that takes power into account, and how we might work to undo the structure. In recognizing that power systems are dependent on the excess of speech, Baudrillard writes:

Thus the strategic resistance is that of the refusal of meaning and of the spoken word - or the hyperconformist simulation of the very mechanisms of the system, which is a form of refusal and non-reception ... it is the equivalent of returning to the system its own logic by doubling it, to reflecting meaning like a mirror, without absorbing it. (Simulacra and Simulation 86).

If, as Baudrillard suggests, the system of simulation doesn't ask for a response from its object of investigation, from the event that it reports, what would silence matter? We have, according to Baudrillard, already been rendered silent, incapable of being heard by the system by the very measure of our voices. Even dissent can only be registered within the confines of the model. Is Baudrillard saying that we should not talk, or write about events? Does he advocate passivity? And, if so, what use could his theory ever be to feminism?

Silence in feminism is traditionally thought of in terms of female disempowerment, as evidenced by Hélène Cixous's war cry, "Women should break out of the snare of silence" (882). It is the historical silence of women that drives many a feminist investigation, where we attempt to give voice to the marginalized, to write women back into history by showing the ways in which women in different historical 
eras influenced society and banded together to fight injustice, or sometimes, to perpetuate it. This historical silence is particularly frustrating to feminists, and is the impetus behind texts such as Tillie Olsen's influential Silences (1978), in which she begins with the question, "why are there so many more women silenced than men?" (24). Silence, for Olsen, is “unnatural” (6) and proof of women's exclusion, "excluded, excluded, excluded from council, ritual, activity, learning, language, when there was neither biological nor economic reason to be excluded" (26). Certainly, when silence is "unnatural," and women have been "excluded," reason would dictate a need for more women's speech, language, and writing. While Olsen's objective is noble, in the desire to get women to write, to speak, and to make their voices heard, she nevertheless recognizes a particular way in which women should speak, in effect inadvertently silencing, once again, those voices that do not conform to the dominant model for writing, for speaking. Olsen expresses frustration with what she calls "writing like a woman" (252):

Being charming, entertaining, 'small,' feminine, when full development of material would require a serious or larger tone in treatments. Pulling away from depths and complexity. Irony, wit, the arch, instead of directness: diffuse emotion or detachment instead of tragedy. Avoiding seriousness altogether. Concealing intellect, analytical ability, objectivity; or refusing to credit that one is capable of them. Abdicating 'male' realms: 'the large,' the social, the political. (252)

It is indeed surprising to find that, according to Olsen, many women who do speak, who do write, have been doing it all wrong. The female voice must conform, not to the 'unnatural silence' that they have been subjected to, but to a more 'natural' masculine 
voice of seriousness, size, complexity, depth, directness, objectivity, and the political. Women must speak within the proper model for speaking. ${ }^{6}$

To what extent then, do feminists perpetuate this silence by arguing in favor of the very language, the very structure that has been used to subjugate and exclude women? As I have been arguing, speaking in accordance with a structure only perpetuates that structure without challenge, exposing a further fascination with the model. The form becomes more important than the content, and thus the form is what will be reproduced ad infinitum. The silenced "feminine" or "woman" writer becomes, in my view, an instance of the (non)conforming, or what Baudrillard terms the "hyperconforming," the mirror that reflects back the model without absorbing it. While I certainly do not want to dismiss the importance of Olsen's work, the ways in which she has influenced both feminists and female writers to pick up a pen, I would nevertheless like to argue for another silence, one that is strategically "unnatural": the surface which challenges the "natural" as depth; the wit and the irony that challenge the seriousness of the political and the social; the detachment that challenges the objectivity of the facts. In this way, silence functions much like seduction, but it is directed toward a different structure: the simulation of reality.

Perhaps the silence that Baudrillard suggests is more akin to Trinh T Minh Ha's use of silence. Before I fully understood the ways in which some feminists perpetuate models for speaking about reality, making those models primary in their investigation of

\footnotetext{
${ }^{6}$ Perhaps Trinh is addressing Olsen in her essay "Difference: 'A Special Third World Women's Issue."” In her discussion of women who write, Trinh states, "She has been warned of the risk she incurs by letting words run off the rails, time and again tempted by the desire to gear herself to the accepted norms. But where has obedience led her?" (5).
} 
women's lives, without questioning the ways in which our concepts (subjectivity, sexuality, and identity) shore up Western analytic power systems, I read Woman, Native, Other: Writing Postcoloniality and Feminism (1989) as merely playful. I read Trinh as challenging feminist concepts of empowerment and as questioning their ability to function in non-oppressive ways. However, upon subsequent readings of Trinh, I began to detect a tone of anger and frustration. Her frustration stems from feminist concepts that bind her to prescribed structures of empowerment, denying her ability to extend beyond them. Trinh writes:

Silence as a refusal to take part in the story does sometimes provide us with a means to gain a hearing. It is voice, a mode of uttering, and a response in its own right. Without other silences, however, my silence goes unheard, unnoticed; it is simply one voice less, or more point given to the silencers. (83)

Silence is what most frustrates systems of meaning and the perpetuation of norms, the simulation of reality. In order to function in accordance with power, it must be made to speak.

Trinh maintains that what has allowed her entrance into discussions and conferences with Western feminists is the fact that she is authentically "different" and “other." In a sense, quoting Trinh allows Western feminists to speak with some authority, without essentialism, on the subject of "other" differences. Trinh suspects that she is consistently invited to lecture on "difference" so that feminism may collect content that they then will place into models for difference: effectively silencing her speech in order to perpetuate the model. In her estimation, it is this obsession with the liberation of speech, but only in accordance with the structure for speaking, that gains her audience: 
"You try to keep on trying to unsay it, for if you don't, they will not fail to fill in the blanks on your behalf, and you will be said" (6). Trinh recognizes that whatever she says will be interpreted for use by Western models. She will be brought into the realm of subjectivity and identity, and will be celebrated in her difference - again, returned to silence. What Trinh asks for is an exchange of silence akin to what Baudrillard refers to above. At the moment that we would like to claim evidence and "subjectivity" or a "difference" for the "other," we silence what is said in favor of speaking in accordance with the simulation of Western norms. In other words, what becomes most important is not what is said, but how a discourse of "difference" can support ideals of female empowerment. Trinh asks for silence, a refusal to perpetuate the model as if it were evidence of reality. Yet, still, many feminists and critics cannot hear this except in accordance with the simulation of academic models for social and political empowerment.

For example, in Postcolonial Theory: A Critical Introduction (1998), Leela Gandhi makes the mistake of lumping together a disparate group of "postcolonial" feminists as essentialist and contradictory, and then articulates the impossibility of listening within the context of a model for reality. According to Gandhi:

Trinh, Talpade Mohanty and Spivak each idealize and essentialize the opacity of the 'real' third-world woman. By making her the bearer of meanings/experiences which are always in excess of Western analytic categories, these critics paradoxically re-invest the 'third-world woman' with the very iconicity they set out to contest. This newly reclaimed figure is now postulated as the triumphant site of anti-colonial resistance. Trinh's rampant prose valorizes the racial, gendered body itself as a revolutionary archive, while Spivak, somewhat feebly, urges the academic feminist to speak to the subaltern woman, to learn from her repository of lived experience. (88) 
In contrast to Gandhi, I understand Mohanty as arguing that there is an ethical, at least a less damaging, way to articulate women's realities, by “understanding the contradictions inherent in women's location within various structures" (Mohanty 74). Furthermore, Spivak articulates a method aimed less at understanding women's contradictions than at the contradictions of the structure for understanding itself. Although vastly different in terms of approach, writing style, and argument, Spivak and Trinh clearly argue that meanings and experiences are not in excess of Western analytic categories, as Gandhi suggests, but are in fact Western analytic categories. Thus any perpetuation of speech about women will occur within the confines of the current structure for power - further perpetuating injustice. It is not that "real" third world women do not exist. It is that they can only exist in the context of Western simulations of reality. The very notion that there is a discernable unmediated objective reality is a Western belief. Spivak and Trinh are interested in the silence that makes reality problematic, or the silence that threatens meaning. Neither Trinh nor Spivak perpetuates the current structural model for power: the perpetuation of speech, the maximization of reality, the insistence on facts and objectivity. Rather, what these feminists do is to engage in a strategy of resistance; employing silence to frustrate the simulation of reality. These two theorists use silence in an effort to disrupt the very models that inform feminist thinking. Silence is a strategy of refusal of subject/object, a refusal of equality/difference, a refusal of center/margin, reality/fiction - that is, of the political backslash that shores up Western ideology in general. 
Gayatri Spivak's essay “Can the Subaltern Speak?” is an example of the kind of feminist engagement with simulation that Grace calls for. Spivak's title is, of course, ironic as it points to the fact that the question of speaking is a model set up by Western philosophical thought from Deleuze to Foucault. The question "Can the Subaltern Speak?" is not aimed at the "object" of investigation or at the "subaltern" but rather at other philosophers. Such a question does not ask for a response from the subaltern, nor does it require one to keep functioning as a model for philosophical investigation. Thus, Spivak creates a mirror effect, what Baudrillard terms silence or a space of hyperconformity to this system, effectively showing the ways in which the subaltern cannot answer a question that does not require a response, and that the question "Can the subaltern speak?" is used to mask the fact that there is no way of uncovering a reality of the "subaltern." The answer to her question is strategically turned toward the philosopher, highlighting the ways in which this question reinforces Western models of knowledge.

In asking "Can the subaltern speak?" Spivak shows the ways in which speech is coded and structured around the philosopher's ideology of what constitutes not only the subaltern but also knowledge. It is the sort of question used to justify the power of Western analytic thought. Spivak creates her own model for speaking by using the madeup quotation, "white men saving brown women from brown men" (92), which simulates colonial reality, or a model by which reality can be tested in any context. She then uses this quotation to show the ways in which history, scholarship, feminism, myth, linguistics, and even first-person accounts of actual events can plug information into a model and end up with evidence of "white men saving brown women from brown men." 
But she also uses this model to challenge the authority of models as such, not only because analytic categories function in the same way, but also in an effort to underscore the ways in which models for reality cannot help but strengthen oppressive ideology, whether intentionally or not. Thus Spivak's formulation, her “algorithm” if you will, exposes the simulation of reality that pervades each account of each event. Spivak argues that in asking the subaltern to speak, we are asking the subaltern to speak within the context of, or in support of, a particular ideology, such that the social realities of women become consistent with Western norms. The speaking subject is always placed within the confines of a context that precede these "realities." We cannot, according to Spivak, learn anything about women's realities by persisting with this task. The challenge is to expose the particular ideologies at work within the idea of the speaking subject, a kind of antirepresentation, to enact an "unlearn[ing] of female privilege" (91), and as such, to enable a radical challenge to the ideology of the speaking subject and "reality."

Addressing feminism in particular, Spivak argues that feminist intervention into the Indian myth of the goddess Sati has attempted to articulate a universal truth of female power without taking into account the ways in which certain myths simultaneously exist as evidence of oppression: "to see this [myth] as proof of the feminism of classical Hinduism or of Indian culture as goddess-centered and therefore feminist is ... ideologically contaminated by nativism or reverse ethnocentrism" (103). While the implication here is that India is a huge country that cannot be reduced to such easy identifications, it is also that the problem starts with the attempt to valorize a feminist goddess-centered India, the reverse of what Mary Daly did when she sought to invest all 
Indian women, as oppressed in so far as they were subject to the widow burning ritual "suttee," neglecting the translation of "suttee" as "the good wife" and its connection to the story of the goddess "Sati." Whether oppressed by "suttee" or empowered by "Sati," Indian women are subject to the same model. By reverse-ethnocentrism Spivak means that this feminist model claims to know what qualifies as feminist within an Indian or Hindu context. Spivak writes, "In my view, individual examples of this sort are tragic failures as models of interventionist practice, since I question the production of models as such" (103). Intervention, for Spivak, cannot be achieved within the confines of a model for reality; indeed her arrow is pointed at models of speaking about reality in general. In the most basic attempt to uncover reality, women's reality, we only learn about the ideological model.

I argue, along with Spivak, Trinh, and Baudrillard, that the frustration of power systems occurs not in the perpetuation of new speech about women but in the silence that surrounds and permeates both the subject of speech and the speaking subject. Spivak nearly reaches this point when she argues for something akin to Pierre Machery's formula for the interpretation of ideology, where what is most important for a work becomes not what is said but what is unsaid:

A method might be built [on Machery's formula], with the task of measuring silences, whether acknowledged or unacknowledged. But rather this, what the work cannot say is important, because the elaboration of the utterance is carried out as a certain journey to silence (81).

Spivak's task, then, is not to prove that what has been said about women in India is wrong, but to suggest that reality is a myth belonging to the reality-maker. At issue is a question not of getting to the real story (for a 'real' story does not exist) but rather of 
returning the story to the design of the model, or showing the ways in which ideology governs every attempt at speaking about reality. There is always a model that constructs any reality we think we can "see." For Spivak "something like a collective ideological refusal can be diagnosed for the codifying legal practice of imperialism," a task that includes "measuring silences" (82).

How does the question of silence disrupt the very ideological practices and simulation that appear in feminism of the postmodern era? Because speech is structured by power, what becomes primary to feminist analysis of the postmodern era is a challenge not just to look at what is said but, indeed, what is unsaid - the silence that turns the "reality" back on itself to indicate the method of investigation. For Spivak, the trick is to thwart systems of power through silence and refusal. Further complicating this task is the problem that, once silence is made to speak (by attributing meaning to that silence), it becomes relegated to the power structure and co-opted for its use. My aim in the remaining section of this chapter is to show the ways in which silence functions in postmodernism as a challenge to the ideology of reality and truth claims, thereby overturning them and exposing them. I explore the significance of silence in literature as an untapped resource for feminism, disrupting power in an era dependant on the proliferation of speech for the propagation of power and control.

\section{Reading for Silence: Postmodern Literature and Feminism}

A too-often overlooked aspect of postmodern literature is the number of silent characters. Most often the silent characters of postmodern literature constitute historically marginalized groups: women, children, and "colonized" men, suggesting that this silence 
is a strategic literary device. To name but a few examples: the unnamed narrator and the "quiet girl” in Maxine Hong Kingston's The Woman Warrior: Memoirs of a Girlhood Among Ghosts (1975); Clara in Isabelle Allende's The House of Spirits (1985); J.M. Coetzee's Friday in Foe (1986) and the Barbarian Girl in Waiting for the Barbarians (1980); Angela Carter's Toussaint in Nights at the Circus (1984); Salman Rushdie's Naseem in Midnight's Children (1981) and Dumsday in Satanic Verses (1988); Don DeLillo's Wilder in White Noise (1985); Arundhati Roy's Estha in The God of Small Things (1998); and Andre Brink's Hanna X in The Other Side of Silence (2004). I argue that in every one of these examples, silence, far from being a sign of oppression and victimization, disrupts and frustrates the ideology of power in the novel. Not only does these characters highlight the ways in which power functions by inciting speech, their refusal or inability to speak challenges the Western assumption that speech is political power. Moreover, each of these characters, by either refusing speech or being unable to speak at strategic moments, drives both the action and plot of the novel, disrupting the traditional link between speech as action and silence as passivity.

While I have long read postmodern silence through a feminist trope that prefigures silence as a metaphor for the oppressed, looking for the ways in which authors empower the marginalized through speech, reading Baudrillard's work challenges us to recognize silence as a strategic disruption of power in the postmodern novel. For, to insist that speech is power, to insist that silence must be made to speak, embraces the very system of power feminism means to challenge. Reading Baudrillard allows me to see that even at the level of plot, the "quiet girl" in The Woman Warrior directly causes an 
inexplicable illness to befall the narrator, from which she cannot recover enough to leave her bed for a year. Clara in House of Spirits, who retreats into unexplained silence for years at a time, is the only character who possesses the magical ability to predict the future and to telepathically manipulate objects in the present. A tongueless and silenced Friday is the only known survivor at the end of Coetzee's Robinson Crusoe retelling, Foe. The silent barbarian girl is the only character, in Waiting for the Barbarians, who manages to escape the confines of evil empire. Born without a mouth and said to take food up his nose, the character Toussaint saves the fantastical women of Nights at the Circus from his employer, the evil museum owner, but also convinces the perpetually disbelieving narrator Waltham to question his insistence upon the divide between reality and fiction. Dumsday is the only character in Satanic Verses who is allowed to escape a deadly group of hijackers on an airplane after his tongue is cut out. Six-year-old Wilder, refusing to speak one word throughout the very noisy novel White Noise, is the only character able to provide relief to his television junkie/ drug addict mother Babbette and to his father Jack who experiences a debilitating fear of death brought about by the overabundance of communications devices that surround them, such as television programs, radio, and advertisements. The young child Estha, in The God of Small Things, purposefully stops talking at the exact moment he recognizes that people in power co-opt speech to perpetuate violence against the innocent. Hanna X, in The Other Side of Silence, manages to wage war, indeed wipes out an entire troupe of brutal German Soldiers, as the tongueless leader of a motley rebel group of oppressed people in South Africa. Silence is hardly a metaphor of oppression. 
Silence in these postmodern novels breaks down coded models for discourse (subject/object, identity/difference), throwing a wrench into ideological power structures dependent on the perpetuation of speech and the simulation of reality. Reading for silence becomes a model for feminist reading aimed at models for feminist reading. The rhetorical strategy of silence does not use silence in the novel in order to make generalizations about realities of under-represented women or minorities, or as an articulation of a kind of reality different from or distinct from Western reality, but rather as a challenge to what is considered reality in the West. For example, what does the story of the Chinese immigrant woman in Maxine Hong Kingston's novel allow us to challenge in Western society, in the feminist ability to create authoritative meaning, and in the social models upon which we rely? Some of the feminist work on Hong Kingston foregrounds the issues I have underscored above in the very titles used to articulate feminist intervention in these novels: Yuan Shu's “Cultural Politics and ChineseAmerican Female Subjectivity: Rethinking Kingston's Woman Warrior” (2001), Ruth Jenkins’s “Authorizing Female Voice and Experience: Ghosts and Spirits in Kingston's The Woman Warrior and Allende's The House of the Spirits" (1994), Margaret Miller's “Threads of Identity in Maxine Hong Kingston's The Woman Warrior" (1983). Feminist buzzwords - female voice, subjectivity, empowerment - abound in scholarship on the novel thereby perpetuating both identity politics, and a call to give voice to the historically marginalized.

According to Miller, Kingston's novel is about "sorting through the threads of her identity" (14). Miller argues that in the novel: 
To have no name is to have no identity: Maxine's aunt is the 'no- name woman.' But her family names are both non-individuating and confusing, and not only to the gods. Kingston's true Chinese pre-name, if she has one, is not known to the reader, as her parents' names are secret from the White Ghosts. (17).

Miller assumes that silence frustrates the characters' search for identity, without taking into account her own level of "confusion" about the concept of identity in this novel. Is the point of the novel the search for identity if the question of identity confuses the reader? The question of identity continues, even when the content cannot support a context for speaking: the word "identity" is not used once in Hong Kingston's novel. While Yuan Shu recognizes “a gap between Kingston's work and feminist interpretations of the work" (201), he nevertheless persists with a feminist model of interpretation in his argument that Kingston's novel is incompatible with feminist politics: "Kingston never challenges the value of individualism per se and actually deploys the discourse of individualism as a means to fight against Chinese patriarchal tradition and to articulate her identity in American culture and society" (204). The only character in the novel who is discussed as having "individualism" is the narrator's "no-name aunt" and, even then, the "individuality" of the aunt is discussed in terms of aesthetics: "At the mirror my aunt combed individuality into her bob" (9). Individualism in the novel is addressed as a construction. Although Ruth Jenkins sees silence in the novel as significant, she nevertheless argues for silence is an alternative rather than a challenge. For Jenkins, Kingston and Allende "re-inscribe female silence as subversive alternatives" (64). This argument would be novel except for the fact that an alternative can only identify another kind of identity, another kind of voice: "Kingston reconstructs a woman, a warrior 
against custom, silenced by her own culture and as a result engenders her own voice, her own identity" (65). In looking to silence as an alternative, what we get is another case of "Are you going fishing? No. I am going fishing." In all of these critical interventions into Hong Kingston's novel most important is the feminist model for reading, reading for identity, reading for subjectivity, reading for difference, such that the novel itself, what it actually says, becomes silenced.

The entirety of Hong Kingston's novel can be discussed in terms of silence. Silence in the novel takes on contradictory roles of protection, repression, penance, punishment, and betrayal. Although silence, as a strategy, varies throughout the contexts of Kingston's novel, it is rarely described as the result of oppression, but rather as that which frustrates those who would like to have it speak, those who need to make speech mean something in order to gain control and power. From the beginning of the novel, we are told that silence is a strategy that avoids Western information systems dependent on the propagation of speech:

The emigrants confused the gods by diverting their curses, misleading them with crooked streets and false names. They must try to confuse their offspring as well, who, I suppose threaten them in similar ways - always trying to set things straight, always trying to name the unspeakable. The Chinese I know hide their names; sojourners take new names when their lives change and guard their real names with silence. (5)

The West in the novel, specifically America, is immediately characterized by an obsession with naming, with making sense, with the easy articulation and explanation of events and people. To speak, to create meaning in the novel, is indeed power, but it is a power that threatens those who would like to see culture saved from the models of information that lie in wait, threatening to reduce a world of traditions into easily 
classifiable meanings. From the beginning, the narrator tells the reader that she both recognizes the Western desire to set things straight, to name, and to codify and that there is a strategic move to thwart these desires. This strategy occurs at both the level of plot (as in actual refusal to speak in the novel) and at the level of narration as our narrator at once recognizes this desire in the Western reader and suggests an aim to mislead, to drive down crooked streets. We know that the narrator is in on this plot to thwart the reader, because she too "guards" the names of characters with silence. Proper names, often refused in the novel, expose a desire to free proper names from use by proper nouns. Spivak says that "there is no more dangerous pastime than transposing proper names into common nouns, translating them and using them as sociological evidence" (101-102). Hong-Kingston employs a strategy of silent resistance here such that it becomes nearly impossible for the academic feminist to speak for her characters except by reference to names such as "The No-Name Woman," "the quiet girl," and "the narrator.” The lack of proper names for characters not only renders it difficult to universalize about a place or a people but also renders such a practice absurd.

The narrator, linking herself with the immigrant strategy of silence, articulates her own problems with speaking as a child. While many feminist critics attribute this silence to the narrator's struggle to find voice, or the "double bind of articulating female voice in cultures that ordain silence as the appropriate expression of female experience" (Jenkins 63), we are told over and over again by the narrator that her silence was not tolerated, was not accepted. On the contrary the narrator's mother cut her tongue when she was a baby so that she would "be able to speak languages that are completely 
different from one another" (164) Similarly, the teachers at school express much concern over the fact that neither the narrator nor her sister will speak. She is also made to speak when she does not want to: "Once a year the teachers referred my sister and me to speech therapy ... Some of us gave up, shook our heads, and said nothing, not one word" (172). Persistent efforts to make the young girls speak are constantly refused, suggesting that silence cannot be reduced to evidence of "the appropriate expression of female experience." While the narrator states that, "normal Chinese women's voices are strong and bossy" (172), she also states that her silence exceeded what was considered American-feminine: "We American-Chinese girls had to whisper to make ourselves American-feminine. Apparently we whispered even more softly than the Americans" (172). While this statement could suggest an oppressive feminine silence, silence (the hyperconformity to the system) serves more as a frustration to the dominant structure of power. Moreover, there is an inconsistency about the cause of the narrator's silence, suggesting that her silence had nothing to do with being a Chinese-American girl and was the result of her mother's tampering with her tongue. The narrator writes:

If my mother was not lying she should have cut more, scraped away the rest of the frenum skin, because I have a terrible time talking. Or she should not have cut at all, tampering with my speech. When I went to kindergarten and had to speak English for the first time, I became silent. (164-165)

Here, the reader is presented with contradictory causes for her problem with speaking: it was her mother's fault for not cutting enough, for cutting in the first place, and it was the 
fault of being made to speak English. ${ }^{7}$ Trying to "set things straight," to find a

rationale for the narrator's occasional refusal to speak, occasional inability to speak, and her occasional imitation of silence is a tiring task, a task that exhausts itself in the search for rational reasoning.

Silence, in the novel, aims to frustrate the speaking world. While it is impossible to codify silence in the novel, to make it mean anything or express the reality of any event, silence does allow the reader to speak to the oppressive structure dependent upon maximizing voice. Silence becomes, in effect, the mirror that reflects the ideology of the Western world without absorbing it. So it is unsurprising that the most violent, emotional, and unsettling moment in the novel occurs when the narrator, who, "finding her own voice," uses it to threaten and enact violence upon a young Chinese-American girl, only referred to as "the quiet girl," who refuses to speak. This scene challenges feminists to question both the positivity that they assume for the "female voice" and the silence that threatens the current power structure. After pinching and threatening her classmate who refuses to speak, the narrator states, "You're so stupid, you don't know your own name, is that it?' When I say, 'What's your name?' you just blurt it out, o.k.? 'What's your name?"” (177). This moment emphasizes not only the ways in which silence threatens the structures for naming but threatens models for speaking, exemplifying the violence or

\footnotetext{
${ }^{7}$ It is important to note that speaking Chinese offers no alternative to power. As the narrator states, "You can't entrust your voice to the Chinese, either; they want to capture your voice for their own use. They want to fix up your tongue to speak for them" (169).
} 
injustice that lies in wait for those who do not comply. ${ }^{8}$ The response to her classmate's silence is behavior she learned in an American school, from an American teacher: "Last year the whole class had laughed at a boy who couldn't fill out a form because he didn't know his father's name. The teacher sighed, exasperated, and was very sarcastic, 'Don't you notice things? What does your mother call him?'” (177). The narrator draws our attention here to the obsession with speaking in compliance with specific forms. The inability to fill out an appropriate name becomes the site of frustration for the teacher, which results in the humiliation of the boy who cannot comply. Here the narrator learns that compelling someone to speak is as much a power play as enforcing silence, and that the refusal to speak frustrates power more effectively than anything one might say. The narrator appropriates the teacher's act of humiliation in an attempt to make the quiet girl speak her name, a seemingly simple task that is continually refused. There are, of course, feminist implications to the line in which the narrator exposes the violence that lurks: “'Talk!' I would scare the words out of her. If she had little bound feet, the toes twisted under the balls, I would have jumped up and landed on them - crunch! - stomped on them with my iron shoes" (178). While the narrator has learned to use the power of speech, she uses it in effect to disempower those who do not succumb to the demand, "talk!" The iron shoes, the mark of power, are used to crush those with bound-feet, the ones who do not speak for themselves, who always must be spoken for, exposing a desire to enact violence upon the speechless, to make them conform, to crunch silence with Western violence.

\footnotetext{
${ }^{8}$ I will return to this point in my conclusion on the silence of women before the Truth and Reconciliation Commission in South Africa.
} 
But as the moment progresses in violent tones, the narrator herself, faced with pervasive silence, loses the advantage that she thinks she has over the silent girl, and lapses into tears, frustrated, unable to speak herself:

"Why won't you talk?" I started to cry. What if I couldn't stop and everyone wanted to know what happened? "Now look what you've done," I scolded. "You're going to pay for this. I want to know why. And you're going to tell me why. You don't see I'm trying to help you out, do you? Do you want to be like this, dumb (do you know what dumb means?) your whole life? Don't you want to be a cheerleader? Or a pompon girl? What are you going to do for a living? Yeah, you're going to have to work because you can't be a housewife." (180)

The rationalization for wanting to "help" make the silent girl talk is that the girl will be able to fit into the models for femininity. Only the silence of the girl points to the emptiness of such models and to the irony of Kingston's language. Silence serves to mock the narrator and the feminine models she holds up as inducements for speaking. Not talking means never conforming to what it means to be an American-girl (a housewife, or a cheerleader, or a productive citizen).

Silence in the story frustrates the narrator's ability to make sense of the world around her. She is angry at the obvious rebellion even in the face of violence. This silence slowly wears the narrator down. Her own words begin to fail, to break down as a result: "Look. I'll give you something if you talk. I'll give you my pencil box. I'll buy you some candy. O.K.? What do you want? Tell me. Just say it, and I'll give it to you. ... But she didn't want anything” (180). Although the narrator relies on many known models for making silence speak: violence, intimidation, kindness, and finally bribery, nothing works. The assertion that the girl "didn't want anything" assumes that silence can always be made to mean something, no matter how ridiculous. It becomes obvious to us, in these 
final moments of this torturous scene, that if the quiet girl did speak, she would transfer power to the narrator. As long as the girl remains quiet, she frustrates the narrator's desire to know. To speak, at this point, would amount to the reinforcement of the narrator's beliefs. The silent girl frustrates the narrator's authority, her ability to rationalize and analyze, her ability to tell the story from more than one perspective. Thus, like Spivak, Kingston exposes the power play in the very question of how to speak for others (Alcoff), or can the subaltern speak.

For those feminists that would still claim that the violence acted out upon the silent girl is evidence of her victimization, I would agree but add that we can only talk of her victimization if we admit our own power to victimize by demanding at all times and all places the necessity for speech. The outcome of the narrator's torture of the quiet girl, of her verbal battle with silence, is, significantly, an undefined illness:

The world is sometimes just, and I spent the next eighteen months sick in bed with a mysterious illness. There was no pain and no symptoms, though the middle line in my left palm broke in two ... I saw no one but my family, who took good care of me. I could have no visitors, no other relatives, no villagers ... I had a bell to ring for help. I used a bedpan. It was the best year and a half of my life. Nothing Happened. (182)

But it has to be asked, how can one stay in bed for a year with no symptoms and no pain? Can this really be cosmic punishment for violence against the quiet girl, if the experience is conversely "the best year and a half of [the narrator's] life?" How does this experience equate with justice in the world? The narrator loses the ability to perform the most basic human functions, suggesting that silence results in the complete break down of systems (bodily and political). While the narrator claims to have no symptoms, the middle line in her left hand that broke in two is telling. The middle line of the left palm is known as the 
"head line" in classical palmistry. According to The Practice of Classical Palmistry"

Anything that interrupts the head line shows interruptions in the thinking process as well .... break in here could indicate a devastating trauma that impeded a person's thinking abilities ... breaks indicate outside circumstances that cause a complete change of attitude. (200)

The physical change in the narrator, and one she refers to as the best year of her life, occurs because her thinking abilities, information systems, broke down in the face of silence. The narrator loses her ability to talk while at home. She must relearn. In a sense she too is rendered silent by the violence of discourse. ${ }^{10}$

The effects of the narrator's experience with "the quiet girl" do not last long. As Kingston's narrator re-learns speech, she falls back on the ideology that a "reality" exists, that the truth about the Chinese can be discovered if only she were to visit China.

${ }^{9}$ In Chinese medical palmistry this line is referred to as the "human crease" or the "head crease," which, if "bisected," indicates "undeveloped intelligence or feeblemindedness" (Chinese Medical Palmistry: Health in Your Hand 83).

${ }^{10}$ While silence in the novel is the primary mode of resistance to meaning, there is evidence of another form of deterrence, which is expressed through lying. The narrator learns from her family the importance of avoiding, at all costs, being placed into social and statistical models by speaking "truth" to the system. According to the narrator, it becomes necessary for Chinese Americans to: "Lie to Americans. Tell them you were born during the San Francisco earthquake. Tell them your parents and your birth certificate were burned up in the fires. Don't report crimes; tell them we have no crimes and no poverty. Give a new name every time you get arrested ... Ghosts have no memory anyway and poor eyesight. And the Han people won't be pinned down" (185). There is recognition in the novel that power systems in the West function through the perpetuation of speech, the insistence upon reality, the objectivity of facts. As opposed to the ocularcentrism of the modernist era, in the postmodern era, what one sees is not nearly as important as what is said. Silence, in matters relating to both "reality" and "truth," is transformed into a political strategy of evasion and deterrence. Reality is that which gets you deported. Speaking "truth" is disempowerment for the individual and empowerment for the system. What matters first and foremost is the refusal to be pinned down, to be kept from moving either through silence on the one hand or lying on the other. 
Suggesting the possibility of finding out the real story, denied by her family's silence, the narrator states: "I'd like to go to China and see those people and find out what's a cheat story and what's not ... Do the babies wear a Mao button like a drop of blood on their jumpsuits?" (206). These questions articulate the Western desire for the real story and also the impossibility of knowing (as these questions go unanswered).

The fact that the narrator invokes the "talking-story" at the end of the novel, a literary form learned from her mother that does not distinguish between reality and fiction, is also significant. As a young girl, her mother's stories served only to frustrate the narrator:

I don't want to listen to any more of your stories; they have no logic. They scramble me up. You lie with your stories. You won't tell me a story and then say, 'This is a true story,' or this is just a story. I can't tell the difference. I don't even know what your real names are. I can't tell what's real and what you made up. Ha! You can't stop me from talking. (202)

The narrator establishes her difference from her mother as a difference between one who makes distinctions between reality and fiction (the narrator) and one who does not (the narrator's mother). The narrator's greatest frustration throughout the novel remains her mother's silence in relation to both naming and making binary distinctions. The narrator exposes a particular Western fascination with speech as the power to differentiate.

However, what she sees as her power over her mother, her ability to talk in binary terms, is refused by her mother's talking-stories. That the novel ends with one such story told in part by her mother and in part by the narrator (though not distinguishing between where the mother's words end and where the narrator's begin) advocates a refusal to maintain the binaries enforced by Western speech. 
As in much criticism of Kingston's novel, silence in Isabelle Allende's The

House of Spirits is typically conceived of as an alterative "voice" or an alternative "space" within feminism. For example, in "The Struggle for Space: Feminism and Freedom in The House of Spirits" (1994), Ronie-Rachele and Garcia- Johnson argue: "Whether Clara's silence is interpreted as a retreat, a refuge ... or as a clever victory over the mundane, it is clear that she entered into an alternative space" (186). But arguing that silence in the novel creates an alternative space does not take into account the ways in which silence functions in the novel as a challenge to existing power structures. The novel begins:

Barrabas came to us by sea, the child Clara wrote in her delicate calligraphy. She was already in the habit of writing down important matters, and afterward, when she was mute, she also recorded trivialities never suspecting that fifty years later I would use her notebooks to reclaim the past and overcome terrors of my own. (2)

Here Allende's unnamed, inconsistent narrator makes the point that, while habit results in recording historically important details, silence or muteness engenders the ability to break down hierarchy whereby triviality is mixed with importance. While the narrator makes the distinction between the important and the trivial, Clara does not.

Allende's opening lines introduce the reader to a strategy that persists throughout her novel in the embodiment of Clara, who, through her silence, continues to break down hierarchies between truth and fiction, magic and science, subject and object, identity and difference. In contrast, for the narrator, silence is a strategy structured by power dichotomies, and is necessary in not only reclaiming the past but also in overcoming the present. Thus Clara, in writing of her sister Rosa, who died very young, does not try to 
articulate a truth, to try to represent her sister faithfully, but rather describes her without using hierarchy: "There was something of the fish to her (if she had a scaly tail, she would have been a mermaid), but her two legs placed her squarely on the tenuous line between a human being and a creature of myth" (4-5). Allende thus makes clear her feminist strategy: Clara's silence allows her to walk the line of power dichotomies, eluding the distinction between reality and myth.

While feminism is specifically addressed in the novel, through the thoughts of Clara's mother Nivea, Western notions of feminism can only go so far in fighting the system. While in church, and listening to the priest giving a sermon, Nivea addresses the pain that she suffers as a result of her corset:

She had often discussed this with her suffragette friends and they all agreed that until women shortened their dresses and their hair and stopped wearing corsets it made no difference if they studied medicine or had the right to vote ... but she herself was not brave enough to be the first to give up the fashion. She noticed that the voice from Galicia had ceased hammering in her brain. They were in one of those long breaks in the sermon that the priest, a connoisseur of unbearable silences, used with frequency and to great effect. (6)

Nivea addresses the fact that the voice she and her fellow suffragettes are using emanates from Europe, which serves to underscore her lack of courage in addressing feminist issues. Nivea's train of thought is broken by silence, which is referred to as "unbearable, "thick," possessing the ability to make "time ... stop" (6), and as producing "anxiety" (7). Out of the silence comes Clara's voice of "purity" (7). "Father Respetro! If that story about hell is a lie, we're all fucked, aren't we ..." (7). That the moment of Nivea's thoughts about feminism is broken with unbearable silence and filled with the voice of young Clara, who later chooses to live the majority of her life in silence, suggests silence 
as a strategy that goes beyond traditional notions of feminism. In refusing to address this scene in the novel, many feminist critics miss the ways in which silence in the novel speaks to feminism.

While the entire novel is told through a re-reading of Clara's notebooks, Clara herself remains physically silent for most of the novel. We are told that, "Clara was ten years old when she decided speaking was pointless and locked herself in silence" (73). The implication here is that speaking has no point, makes no difference in this novel, and that silence has a goal, is strategic. Whereas Clara's grandmother, Nana, claims that it is common for young girls to be telepathic and that Clara would lose her telepathy upon adolescence, the fact that Clara refuses to speak is tied to the fact that Clara never loses her ability: "Clara's ability to move objects without touching them did not disappear with the onset of menstruation, as Nana had predicted, but rather became more pronounced, until she was so accomplished that she could move the keys on the piano with the cover down" (77). The refusal of speech is thus also linked to the ability to manipulate objects with the mind, an "accomplishment" that breaks down the division between subject and object: the keys of the piano are linked with Clara's mind; they do not exist as separate entities. Nana's suggestion is that it is common in youth not to distinguish between subjects and objects, that to distinguish is a learned behavior, but that Clara's silence lets her refrain from re-producing such power structures long after the onset of maturation.

Clara does not speak again until her nineteenth birthday when she declares to her parents that she will marry Esteban Trueba. While Clara speaks more in the years that follow her marriage, including the years of her first child's birth, it appears that the more 
she speaks, the less she can change her surroundings, to challenge the dominant social structure: "And Clara too had changed. From one day to the next, her listlessness had vanished, she stopped finding everything so 'lovely,' and she seemed to be cured of her habit of speaking with invisible spirits and moving furniture by supernatural means" (105). It is not insignificant that the moment that Clara begins to speak is also the moment that she turns to relying upon binary distinctions. Relying on traditional models for empowerment, Clara begins to enact traditional methods for power upon the "disempowered" and "oppressed" women workers on the estate of her home Tres Marias. Organizing meetings for women on the estate, Clara, we are told, "used the meetings to repeat the slogans she had heard her mother shout when she chained herself to the gates of Congress" (16). Relying on these feminist methods requires that Clara ignore the fact that she is forcing the women to attend the meeting out of fear of angering the patron's wife. She also refuses to ask the question of whether these models are appropriate for all women, especially the women in Tres Marias who have nothing in common with Clara. The narrator informs the reader that Clara's "inflammatory cries only made them laugh" (6). Clara buys into the notion that all women have a shared experience by nature of their gender. She ultimately succeeds only in igniting the anger of her husband, who, though a violent man before marrying Clara, kept his violent nature in check up to this moment: "he shouted like a madman ... arguing that if Clara intended to follow her mother's footsteps, she would come face to face with a real man, who would pull her pants down and give her a good spanking" (106). Working in opposition to the dominant social structure does not effect change, but rather incites violence. 
Clara realizes the error in her desire to introduce Western notions of gender equality to help the people of Tres Marias only after she recognizes the weakness in Western analytic thought. When Tres Marias is infested with ants, Esteban hires a "gringo" to get rid of them: "When he finished identifying the species, its lifestyle, the location of its burrows, its habits, and even its most secret desires, a whole week had passed and the ants were beginning to crawl into the children's beds" (110). Western methods are exposed as not only ineffectual but also, in the search for the desire of ants, absurd. Pedro Garcia eliminates the ants that have infested the land by simply asking them to leave, after a paid Western scientist with his experiments and tests fail. Clara discovers that the people of Tres Marias know there are other ways to address social problems than those provided by the models of the West. Immediately after this scene, Clara stops "helping" the people and becomes silent once more: "Clara reverted to her visionary tasks, speaking with apparitions and spending hours writing in her notebooks" (112). What is visionary about Clara is her ability to break down hierarchies of thought rather than engaging in them. ${ }^{11}$

Silence is not a strategy that is limited for use by women authors. On the contrary, silence in postmodern literature persists as a strategy that is not gender specific. Silenceas-strategy is perceptible in most of J.M. Coetzee's works written under apartheid in South Africa: Waiting for the Barbarians (1980), The Life and Times of Michael K

\footnotetext{
${ }^{11}$ Clara is representative of the kind of feminism supported by Trinh T. Minh Ha, who writes: "I undeniably prefer the heterogeneity of free play in a dice game to the unity and uniformity of dissection, classification, and synthesis toward a higher truth. It is within the reign of worn codes, or perhaps more precisely, here within the boundaries of what he says he is or does that I intend to play and spin" (Woman, Native, Other 49).
} 
(1983), Foe (1986), and even in his first novel published after apartheid, Disgrace

(1999). While silence is traditionally viewed, by feminist and postcolonial theorists alike, as a continuation of colonial oppression, I argue that such a position is too often used as a deterrent from engaging these texts as critiques of Western power structures. For example, in "Speech and Silence in the Fictions of J.M. Coetzee" (1998), Benita Parry argues that, in Coetzee's novels, "the potential critique of the political is diverted by conjuring and endorsing of a non-verbal signifying system" (153). Parry's insistence upon Coetzee's endorsement lets the reader off the political hook, keeping us from engaging Coetzee's silent characters as a critique (153). In such an argument, the text is to blame. While it is certainly possible to read silence in Coetzee's novels as a continuation of colonial oppression, in what way does such a reading practice re-inscribe the oppression that feminist and postcolonial scholars would like to see challenged? Continuing to read through a Western lens that prefigures speech as empowerment and silence as oppression recreates, indeed stages, the oppression of the other in our readings of Coetzee's novels. Such a reading practice invests silence, or absence, with meaning, "oppression," even as Friday's silence in Coetzee's retelling of Daniel Defoe's Robinson Crusoe, Foe, according to Parry, makes him "less available to the attention of conjectural readings" (155). Where Friday's silence makes him unavailable to conjecture, critics have moved away from Friday himself and looked to the dominant ideology to support their readings of him. In this way, Friday is doubly silenced, purposefully by Coetzee and unintentionally by Parry who assumes that Friday's silence is "outside the formal structures of language" (155), and thus cannot serve to critique such structures. 
Baudrillard's claim that that "any movement that believes it can subvert a system by its infrastructure is naïve" (Seduction 10) allows me to argue that the opposite of Parry's argument is also possible: that a close reading of the text reveals the ways in which silent characters, like Friday, function to question the authority of what is said, the authority of the text's central speaking characters. Such a view does not prefigure silence as oppressive, an easy assertion based on an already dominant viewpoint, but as challenging the dominant modes of Western discourse and ideology. Friday's silence can neither reinforce nor oppose Western ideology. But it can challenge ideology's ability to function, and it can highlight the impotence of meaning-making systems. Friday's silence functions not only to reduce reality to the level of myth, but to show the ways in which reality is a function of imposing meaning on silence. Thus when Susan Barton says to Foe, "We must make Friday's silence speak, as well as the silence surrounding Friday ... As long as he is dumb we can tell ourselves that his desires are too dark for us, and continue to use him as we wish" (142-148), she is performing the perversity of Western liberation systems. Susan's assumption is that making meaning of Friday's silence is less of a colonialist agenda than keeping him silent. However, in both cases, it is only Susan's and Foe's desires that are expressed. Repression of speech and its liberation are both the function of power structures that seek to use Friday "as we wish."12

\footnotetext{
${ }^{12}$ Critics often make the same mistake as the characters in the novel in trying to make Friday's silence speak, to make him function in relation to Western methods of interpretation. Evidence of this can be found in Parry's assertion that, "it is intimated that the dumb Friday is without tongue and perhaps without phallus" (153). But how can Friday's absence of tongue be equated with a loss of power when he serves as a constant frustration to both Susan Barton and Foe who attempt to make meaning of him? Friday's lack of tongue becomes that which frustrates their desire to know, and thus to control,
} 
Parry's strongest critique of Coetzee is that while he, at the time of her

writing, wrote three novels from the perspective of a female narrator, he refuses to write from the point of view of the "dispossessed." Parry argues that the effect of "granting authority" to the woman's text while withholding the language of the "dispossessed" is to:

reinscribe, indeed re-enact, the received disposal of narrative power, where voice is correlated with cultural supremacy and voicelessness with subjugation; just as the homages to the mystical properties and prestige of muteness undermine the critique of that condition where oppression inflicts and provokes silence. (158)

Parry assumes that Coetzee allies himself with the woman's movement but continues the oppressive colonialization of the other by refusing to give voice to the dispossessed. However, not all of Coetzee's novels "grant authority" to female characters. Indeed, many of Coetzee's female characters are similarly silent, throwing Parry's assumptions into question. Furthermore, speaking, in Coetzee's novels, does not necessarily indicate a granting of authority. In many cases, characters that attempt to speak for others only end up stripped of authority, the most obvious example being Coetzee's Magistrate in Waiting for the Barbarians. In her critique of Coetzee's silent characters, Parry only briefly mentions the novel Waiting for the Barbarians, an elision that I find troubling, not only because the novel does not give voice to the female character, but also because it was published prior to Foe and thus provides clues to reading Friday. Whereas Parry argues that the barbarians are like Friday in that that they "are muted by those who have

Friday. Can Friday's lack of tongue really be an indicator of his powerlessness when he is the only recognizable character left alive at the end of the novel? I continue to have doubts about the usefulness of applying Western ideological systems, here implied by Parry's psychoanalytic interpretation, to readings of Friday. 
the power to name and depict them" (151), the barbarian girl in Waiting for the

Barbarians, like Friday, continually functions as a source of frustration to the Magistrate, Susan, and Foe. The fact that the Magistrate is unable to make sense of the barbarian girl or her actions cannot be separated from the political and sexual impotence he experiences as a result of his misreadings of her. In this way, Coetzee not only investigates a political structure that relies heavily on speech in order to enact power over the "other," but also suggests silence as a strategy to overturn such structures. What is left at the end of the novel is an Empire weakened in its inability to know the barbarian and thus justify power and colonization.

The barbarian girl's silence underscores the inherent contradictions of empire and the impossibility of subversion from inside the political structure. Indeed, her silence shows the ways in which the power of empire lies in its conflation of reality with ideology. Expressing frustration at his inability to make the barbarian girl mean in accordance with his perceived notions for power, the Magistrate defines the silence of the barbarian girl in relation to the prostitute who gives him power through pleasure:

But of this [barbarian girl] there is nothing I can say with certainty. There is no link I can define between her womanhood and my desire. I cannot even say for sure that I desire her ... I have just come from the bed of [another] woman for whom in the year I have known her, I've not for a moment had to interrogate my desire: to desire her has meant to enfold her and enter her, to pierce her surface and stir the quiet of her interior ... But with this woman it is as if there is no interior, only surface across which I hunt back and forth seeking entry. Is this how her torturers felt hunting their secret, whatever they thought it was? For the first time I felt pity for them: how natural a mistake to believe that you can burn or tear or hack your way into the secret body of the other! The girl lies on my bed, but there is no good reason why it should be a bed. I behave in some ways like a lover - I undress her, I bathe her, I stroke her, I sleep beside her - but I 
might equally tie her to a chair and beat her. It would be no less intimate. (43)

What frustrates the Magistrate, first and foremost, is his inability to account for the barbarian girl. All of the ideological systems for knowing her fail in the face of her silence. She becomes the surface that challenges the depth of the magistrate's masculinity, of his power. Unlike the prostitute, he cannot penetrate her. He cannot presume power over her. He cannot define her according to what he knows about desire. The barbarian girl cannot prove his masculinity or his prowess as the prostitute can. In this moment the "one just man" of empire identifies with the girl's torturers who similarly seek a "reality," a "truth" that is not there. Her silence becomes most frustrating for those who would seek the truth either through demanding speech or through expecting the physical body to produce meaning. It is only through the barbarian girl's silence that the Magistrate is led to the conclusion that torture of the female "other" includes all systems that impose meaning, speech, and interrogation upon her.

Immediately following this scene is evidence not only of the magistrate's physical impotence but also of his breakdown. The Magistrate's wavering between his guilt and innocence provides evidence for the impossibility of justice in a colonial system that imposes meaning on the "other":

I shake my head in a fury of disbelief. No! No! No! I cry to myself. It is I who am seducing myself, out of vanity, into these meanings and correspondences. What depravity is it that is creeping upon me? I search for secrets and answers, no matter how bizarre, like an old woman reading tea leaves. There is nothing to link me to her torturers, people who sit waiting like beetles in dark cellars. How can I believe that a bed is anything but a bed, a woman's body anything but the sight of joy? I must assert my distance from Colonel Joll! I will not suffer for his crimes. (44) 
The Magistrate would like to take back his earlier assertion that he is no different from those, like Colonel Joll, who tortured the barbarian girl. But in order to do that, he must assert that the barbarian girl's body means nothing save "joy," or the pleasure of men. However, as his justification of innocence, too, relies on the meaning that he attributes to the barbarian girl's body, he cannot escape suffering. If the meaning he formerly gave to the body of the barbarian girl (secret) makes him guilty, reading her body through another meaning (joy) cannot make him innocent.

The Magistrate admits that the meaning he tries to make of the barbarian girl's silence is an attempt (though a futile one) to enact power over her, a power that he cannot achieve sexually. The Magistrate muses:

So I begin to face the truth of what I am trying to do: to obliterate the girl. I realize that if I took a pencil to sketch her face I would not know where to start. Is she truly so featureless? ... How ugly, I say to myself. My mouth forms the ugly word. I am surprised by it but I do not resist: she is ugly, ugly. (47)

That the barbarian girl is deemed ugly now cannot be separated from the fact that the Magistrate is powerless to represent her, to summon her into his mind, to draw her with features. His desire to "obliterate" her is linked to the fact that she serves as a persistent challenge to his ability to know, to make meaning, and thus to enact power over her. Coetzee links power under empire with the ability to represent "the other." Through the Magistrate, Coetzee shows the underlying violent tendencies that emerge when "the other" refuses to lend strength to Western powers of representation.

Even though the Magistrate does not physically harm the barbarian girl, the ideology that informs his feelings of power is not so different from Colonel Joll's. In 
justifying his use of torture Colonel Joll states: "First I get lies, you see - this is what happens - first lies, then pressure, then more lies, then more pressure, then the break, then more pressure, then the truth. That is how you get the truth" (5). Where the Magistrate astutely points out that "pain is truth: all else is subject to doubt" (5), the reader notes that what matters most for Joll also is pain. The desire for truth is merely a justification for power. Because Joll's discussion of torture eerily resembles the Magistrate's description of massaging the barbarian girl's body ("First comes the ritual of the washing; for which she is now naked." [30]), we must also question whether the Magistrate also uses his search for reality as an excuse to justify power over the barbarian girl. The Magistrate massages the girl in the hopes that her body will reveal what really happened. His questions, "What did they do to you?" and "Why won't you tell me?" (31), at once distinguish his difference from Joll and underscore their similarity.

It is not insignificant that the only character who is able to escape the confines of empire unimpeded is the barbarian girl. As the presence of the barbarian girl serves only to reinforce the Magistrate's powerlessness, not only to possess her but also to end the torture of innocent barbarians, his peace of mind returns once the Magistrate decides to take her back to her people: "Now that I have committed myself to a course I sleep more easily and even detect something within myself like happiness" (58). Happiness, for the magistrate, occurs once he stops making fruitless attempts to know the barbarian girl. However, that the Magistrate cannot function without the reinforcement of meaning, that silence disrupts the ideological systems that perpetuate power, should not be lost on the 
reader. The barbarian girl must go, not only because the Magistrate is just but also because her silence threatens him.

In this chapter I have argued that silence in postmodern literature and feminist theory frustrates ideological power systems that rely on the perpetuation of speech. However, the question remains as to whether silence can be used outside of theory and fiction, can be used to engage with actual events. In my conclusion I take Baudrillard's theoretical concept of simulation as a model for rethinking power and the political by showing the ways in which simulation allows us to re-think reality in an increasingly global postmodern society. 


\section{CHAPTER SEVEN}

\section{CONCLUSION}

\section{A SIMULATION OF TRUTH: RECONCILING GENDER IN THE MEDIA AND THE TRUTH AND RECONCLIATION COMMISSION IN SOUTH AFRICA}

The following readings of women's silence in the post-apartheid hearings before the Truth and Reconciliation Commission (TRC) explore the political significance of the shift from modern seduction to postmodern silence. In light of the discourse established by the TRC, where political power and reconciliation are restored through public speech, it is important to examine ways in which women, like the female characters in postmodern literature, challenge the social and judicial system that failed to represent them. By paying particular attention to silences within the testimonies, I raise the question of whether speech ever equals power. Reading testimonies and literature together, I seek to establish a new discourse recognizing the political significance of silence as, in Baudrillard's words, "the immense, latent defection" from productivist discourse (Mirror Of Production 141).

In 1994, after the fall of the Apartheid regime, the new South African government introduced plans for a Truth and Reconciliation Commission (TRC). The truth commission was structured such that political activists and everyday citizens, bearing the burden of torturous memories, could stand before their fellow South Africans and give voice to unimaginable stories of human rights violations. For two and a half years, details 
of the commission aired daily on public radio, television, and in local and national newspapers. The commission became the subject of international controversy because of its inability to bring apartheid criminals to justice and its failure to represent entire segments of the community. Even though there were an equal number of women and men who testified, the final TRC report showed that, when women reported violations, it was about the loss of husbands, children, and family members. Women did not speak about the bodily harm they themselves sustained. In "Building a Postcolonial Archive? Gender, Collective Memory, and Citizenship in Post-apartheid South Africa," Cheryl McEwan comments on this elision:

The TRC focused on the most extreme abuses and events but virtually ignored the countless horrors that people, and especially black women, faced in their daily struggle to survive ... Truth telling has historical, political and healing significance, but some truths, such as those from women, were underrepresented in the collection process and thus remain underrepresented in the national memory-archive. (746)

McEwan's mention of a "national memory-archive" alludes to the media's function as national memory maker. South Africans who did not attend the hearings remember the TRC as a series of daily media broadcasts. But McEwan's statement that women's experience was simply underrepresented does not account for the ways in which women's testimony was manipulated in support of post-apartheid rhetoric about reconciliation. In this conclusion I argue that women's speech was co-opted by the media in its effort to create a community of awareness about apartheid and post-apartheid "reality." I maintain that the ideology informing television, radio, and newspaper coverage did not allow for female torture and abuse narratives. In the case of the TRC, 
where speech was continually adapted for public consumption, silence challenges the truth claims of the media and the objectivity of representation.

In the year 2000 two American filmmakers, Frances Reid and Deborah Hoffman, directed a documentary entitled Long Night's Journey into Day. ${ }^{1}$ The documentary gives an inside view of the TRC by providing access to testimony, newspaper reports, journalist interviews, and radio and television coverage. The documentary aims to present a wide range of testimony, including stories told by victims and perpetrators, men and women, and white and black South Africans. What emerges, however, is a cultural discourse that establishes women as the victims of apartheid injustices and men as political activists. It was a simulation of truth.

In Simulations, Baudrillard defines simulation as the ability "to feign to have what one hasn't" (5). More precisely, "Simulation threatens the difference between true and false, between real and imaginary, since it produces true symptoms" (5). Baudrillard uses the term "simulation" to describe the way in which the media neither simply reports nor necessarily creates meaning but rather stages meaning. Therefore, the information

\footnotetext{
${ }^{1}$ The documentary, as a genre, is a form of realism. Literary scholars understand realism as a set of conventions. As Catherine Belsey explains, “... the form of the classic realist text acts in conjunction with the expressive theory [of language] and with ideology by interpellating the reader as subject. The reader is invited to perceive and judge the 'truth' of the text, the coherent, non-contradictory interpretation of the world as it is perceived by an author whose autonomy is the source and evidence of the truth of the interpretation" (68-69). The conventions used in literary realism are not dissimilar to those used in documentary filmmaking in that the audience is asked to judge the "truth" of the film by being presented with a non-contradictory interpretation of the world as perceived by the filmmaker. But audience members and filmmakers tend to view documentaries as a reflection of the real, buying into the ideology of realism that Belsey exposes.
} 
presented is no longer the "truth" or "real" but hyper-real (where "truth" cannot be separated from representation). We accept the media message as truth because we see simulation as reality and there is no longer anything standing in opposition to it.

Even before the TRC opened, before the first testimony aired, the media presence, complete with microphones and video cameras, was palpable. The process of simulation had begun with the media as master symptom producer. On day two of the TRC hearings, the dominant message staged by the media was clear: trauma, mourning, and victimization. Four women, from the township of Craddock, appeared before the TRC to tell the story of the trauma they faced on the day their husbands and sons (The Craddock Four) were brutally murdered by the apartheid special forces. Long Night's Journey into Day chronicles a section of the testimony of Nomonde Calata, widow of the murder victim Fort Calata. Ms. Calata states, "you know what have hurt me the most is to hear that he was killed and after he was killed, his body were burned. You know that hurt me a lot.” During the course of her testimony, Ms. Calata broke down into sobs and wailing; language failed her.

Although Long Night's Journey into Day does not include Ms. Calata's full testimony, or her complete breakdown, Antjie Krog, a journalist covering the hearings, and Alex Boraine, a TRC commissioner, both remember Ms. Calata's testimony as a defining moment in the TRC process. In her award-winning book Country of my Skull, Antjie Krog states, "for me, [Ms. Calata's] crying is the beginning of the Truth Commission - the signature tune, the definitive moment, the ultimate sound of what the process is about" (42). Crying is the beginning, the anticipated symptom. The media turns 
Ms. Calata's crying into a signifier of "truth," reproducing the sound of her cry on the airwaves until it becomes an instance of the hyper-real. ${ }^{2}$ In A Country Unmasked: Inside South Africa's Truth and Reconciliation Commission, a detailed memoir of his experience as founder and Deputy Chair of the TRC, Alex Boraine emphasizes the strong public response to the media's repetition of Ms. Calata's breakdown: "Nomonde Calata's sorrowful cry was played over and over again by the SABC. Many people told me afterwards that they found it unbearable and switched off the radio" (103). The fact that Ms. Calata's verbal testimony was never completed, while her non-verbal sounds reverberated across the airwaves, demonstrates that the media found the appropriate symptom for its message.

For Baudrillard, "Every image, every media message ... is a test-- that is to say, liberating response mechanisms according to stereotypes and analytic models" (Simulations 120). That is, the media relies heavily on anticipated stereotypical responses. A media message will necessarily represent what is both easily recognizable and predictable for its intended audience (in this case, the South African public, though also an international community of onlookers). Female representation was necessary as a test of the media's "inclusiveness," and Ms. Calata's cry was media-worthy; the cry of a woman in mourning came to stand in for the entire TRC process. The literal cry became a metaphor: the woman is country; the country is mourning the loss of her people. After the

\footnotetext{
${ }^{2}$ Laura Moss, in "'Nice Audible Crying': Editions, Testimonies and Country of my Skull," asserts, "the TRC report of Nomonde Calata's testimony provides a more located and specific, and ultimately more responsible, narrative of the testimony than Krog, precisely because it locates the testimony in a real physical space rather than forcing it into a metaphorical landscape or situating it primarily in a national narrative" (95).
} 
widows give their testimony, Long Night's Journey into Day provides a radio

voiceover: "It is now eighteen minutes past seven. South Africans are weeping. The raw pain and deep emotion of the truth commission has brought tears to many eyes, black and white alike. Victims...." Ms. Calata's cry came to represent an entire victimized, feminized nation. The cry became synonymous with women's reality in post-apartheid South Africa and gradually subsumed all other female experiences of the apartheid regime. Thousands of women came to testify before the commission, few deviated from the message established by the media.

Consequently, there was no need to question the truth about women's reality in post-apartheid South Africa; the truth had been seemingly exhausted. After several months of testimony Antjie Krog wrote:

I am suddenly sick and tired of the Truth Commission.... And the women! They have never managed to subvert the developing stereotype of the Commission: women as victims, men as fighters and leaders. They never take the lead in any considered directed way. At the hearings they easily become sentimental or moralistic. They're ... reveling in the role of the supportive little woman. (236)

It is indeed interesting that the journalist who in the beginning claimed that the cry of Ms.

Calata was "what the process is about," herself cries out, overwrought by the mass production of her claim. ${ }^{3}$ Like the people who turned off the radio in response to the

\footnotetext{
${ }^{3}$ Laura Moss argues, "Krog articulates the messiness of dealing with the past in the present through a montage of voices and facts. In this montage, however, and perhaps because of this montage, the actual voices of the victims of Human rights abuses sometimes get lost among the emotions of 'Antjie' as various versions of the narratorreporter overcome a sense of guilt and a recognition of complicity" (90). We must understand this complicity as two-fold: complicity with the government-mediated journalism practiced under the Apartheid dispensation, and complicity in the creation of a nationalist mediated journalism (often associated with gender discrimination) while
} 
overexposed cry of Ms. Calata, Krog expresses frustration and impatience that exemplify what Baudrillard terms "the allergic world," a "world of excess, of an oversensitivity to anything whatever - precisely, to others" (The Perfect Crime 145). In other words, the "allergic world," as Krog's comment unwittingly reveals, produces a negative reaction to the overproduction of information and an excess of meaning - a response that Krog is, in part, responsible for.

A section of Long Night's Journey into Day also chronicles the testimony surrounding seven men murdered by apartheid police in the township of Gugulethu. Again, the wives and mothers appear before the commission. After their testimony, the women are asked to face a repentant black apartheid police officer responsible for the death of their male family members. ${ }^{4}$ Before meeting the perpetrator, the women were briefed by a psychologist. Under the lights of running video cameras, each woman expresses an adamant refusal to forgive. For example, Irene Mxinwa's assertion, "saying sorry is not going to help," and Cynthia Ngewu's dismissal, "my child is dead. Whatever he says will not alter that," illustrate the strong resistance of these women to the political aims of the commission. But adamancy melts into forgiveness as the women enter the room with the former apartheid police officer. The cameras are, of course, still rolling as each woman embraces the man who killed her hopes for the future.

reporting for the TRC.

${ }^{4}$ Why would the TRC ask these women to meet with a former apartheid police officer? As Giuliana Lund explains in "'Healing the Nation': Medicolonial Discourse and the State of Emergency from Apartheid to Truth and Reconciliation": "To continue to insist on healing and forgiveness in the context of apartheid's worst excesses can be perceived as a form of coercion that compels the witness to place his or her own needs after those of the nation" (108). 
Has, then, the transformative and restorative power of forgiveness promised by the TRC been publically achieved in this moment? In The Perfect Crime, Baudrillard argues, "given the mass of evidence, there is no plausible hypothesis but reality. Given the mass of evidence to the contrary, there is no solution but illusion" (1). That is, while the media creates a simulation of reality, it also creates an illusion of reality. This is not to say that the testimony of women's ability to forgive was an illusion. The illusion is seeing this level of forgiveness as typical, representative. But as Baudrillard writes, "every singular moment can be reckoned exceptional. And it puts an end to all others" (Intelligence of Evil 102). More to the point, any media-worthy moment is highlighted and reinforced, rendering mute the moments that precede or follow it. "The Gugulethu Seven" commission hearing was indeed exceptional: these women whose lives were ruined by a black South African apartheid police officer forgave the treason. The case became a landmark, a symbol and an icon for the emphasis the TRC placed on forgiveness and reconciliation. ${ }^{5}$ It provided the necessary illusion to prove that the process was working. ${ }^{6}$

\footnotetext{
${ }^{5}$ Stated in the notes to the first draft of the Promotion of National Unity and Reconciliation Bill, "reconciliation depends on forgiveness and that forgiveness can only take place if gross violations of human rights are fully disclosed. What is therefore envisioned is reconciliation through a process of national unity" (Ross 13).

${ }^{6}$ Of Cynthia Ngewu's selfless capacity to forgive, Alex Boraine writes, "Ngewu was bereaved and deeply angry, but, remarkably, she thought not only of her particular needs, which were great, but the needs of the very people who killed her son. If this is not the beginning of reconciliation in a particular person as well as in a particular community I don't know what is" (353).
} 
A glimpse back at previous stories presented in Long Night's Journey into

Day, however, proves that most women's testimonies did not result in forgiveness. In the case of the Craddock Four, when former apartheid police officer Eric Taylor asked to meet the widow of the man he had murdered in cold blood, Nyami Goniwe states, "I'm not going to absolve him... I refuse to do that. Umm, he can use, I mean, the TRC for that." Similarly, Sharon Welgemoed expressed only disgust for Robert McBride, the ANC military official who set off a car bomb in Durban, killing her sister and two other women. Welgemoed exclaims, "Mr. McBride is a cold blooded murderer who can never wipe away the pain, sorrow, and anguish he has caused." Significantly, Long Night's Journey into Day presents Ms. Calata, the woman whose cry came to define the TRC process, as among those women who were unable to forgive: "Ah Mr. Taylor, it is going to be very difficult for me to say that I forgive you, for what you did to me. Because you have caused so much pain to me and my family." In this way, the documentary exposes, however unintentionally, the broadcast media's exclusive attention to Ms. Calata's gendered cry of pain - an instance of the hyperreal. Regardless of strong evidence to the contrary, radio, television, and newspapers framed women by their selfless capacity to forgive. Thus, despite their active resistance to the process, women in post-apartheid South Africa were instated as victimized witnesses, unfortunate recipients of grave injustice yet clear reconcilers ready to forgive their offenders.

While the media uses simulation to stage the "truth" and reality, it also uses dissimulation to detract from meaning that is antithetical to its message. As Baudrillard notes, "To dissimulate is to feign not to have what one has" (Simulations 5). Because 
simulation produces the symptoms of the media message, it follows that dissimulation denies symptoms to the contrary. In any narrative that produces symptoms contrary to the message (in this case, strength, survival, and agency), the media must find a way to undercut the symptoms and reinstate the simulation of reality. It must deny the acquisition of divergent facts and turn its lens from the "truth."

In her book Bearing Witness: Women and the Truth and Reconciliation Commission in South Africa, social anthropologist Fiona Ross provides transcribed testimony of one of the few female anti-apartheid activists to appear before the commission. An active underground member of the African National Congress (ANC), Yvonne Khutwane's narrative is one of arrest, detention, torture, violence, and the bombing of her home by apartheid police forces. In testimony regarding her detention, Ms. Khutwane says, "They [the police] said if I defy them I will be detained for years and I will never get out of prison again ... I said I didn't care; they can do whatever they liked" (83). Clearly a message contrary to women's reality as defined by the media, Ms. Khutwane's testimony is one of strength, agency, and a determination to defy the demands of the apartheid police. Ms. Khutwane also describes her return home to the township of Gugulethu after her release from prison: "I was being ridiculed by everyone because my house was destroyed through arson. But I never turned my back on them. I am still an ANC member" (85). Ms. Khutwane identifies herself as a continuing, active, and loyal member of the cause, regardless of the fact that the ANC turned its back on her. Only later on in her testimony, after being prompted, interrogated (and interrupted) by a member of the commission, does Ms. Khutwane admit that she also had been raped, 
providing the media with the means to turn her story away from agency and back to the message, where the act of rape is less important than its symbolic function.

Here is how Yvonne Khutwane's testimony was reported by the South African Press Association: “A Worchester mother of four on Monday told the Truth and Reconciliation Commission how she was sexually molested and tortured by security force members ... for her involvement in African National Congress activities" (qtd. in Ross 89). The media focused primarily on Ms. Khutwane's status as mother, to her victimization and sexual assault, and ended by reporting that she was involved in ANC activities (but not that she remained an active member). Similarly, The Cape Times reported: "Soldiers the same age as her own children sexually assaulted African National Congress veteran Mrs. Yvonne Khutwane” (qtd. in Ross 90). Again, Ms. Khutwane was represented as a mother, a victim of sexualized crime, and as a former member of the ANC. Later, in the same Cape Times newspaper article, the journalist reporting states, "When she cried, they threatened to shoot her" (qtd. in Ross 91). But, as Fiona Ross states, "Mrs. Khutwane did not state [in her testimony] that she had cried or that the men threatened to shoot her" (91). Drawing upon the radio broadcast of Ms. Calata's testimony, the simulated cry becomes a necessary fiction in order to situate Ms. Khutwane's testimony within the media-inspired gendered discourse. The emphasis on the sexual crime is not only an overgeneralization of Ms. Khutwane's story but also a denial of political agency. Focus on Ms. Khutwane's status as mother and on her sexual assault over that of her ANC activities reinvents her as a passive victim. This is dissimulation. 
Both simulation and dissimulation render a disservice to the "victim" by failing to acknowledge his or her world as in and of the political, as in and of the apartheid system of hatred and racial segregation. To claim victimization is to take a woman out of her everyday reality through the cry of misfortune. The media thus makes outsiders and witnesses out of women who were inside and active political participants, denying women the power of knowing that they, too, were part of the system, even if they were not responsible for it. A kind of false advertising arises in the form of sympathy over loss and grievances.

However, no citizen of a racially segregated country should be viewed as being outside of the political. These were not extenuating circumstances; everything was despair. This was life under the apartheid dispensation. Everything was political. To insist on women's victimization is a lie and a deterrent-- a deterrent from speaking about everyday life, with its police raids, detention, harassment, and arrest. Simulation and dissimulation of reality, based on the claim of misfortune, ensure that the female remains a witness before the commission, testifying as a witness, rather than an active political member. As such, women's agency is denied.

The fact that most women downplayed their political involvement, their torture and detention, must be seen in direct correlation with media representation. Even women who were clearly active members of the anti-apartheid movement were publicly stripped of power and agency through the reinstatement of gendered victimization in service to the media message. Through the acts of simulation and dissimulation the media became a deterrent to any narrative that opposed its meaning. Most women who identified as 
political agents declined to appear. When journalist Antjie Krog asked an anonymous woman why she refused to testify, the woman argued, "the day I became involved in the struggle, that day I made a choice and I fully understood the consequence of it. To run to the Commission now just doesn't seem right" (181). Understanding the magnitude of the public message, the anonymous political activist recognizes her circumstance as outside of the TRC process. She intentionally joined the struggle as an active member of the antiapartheid cause. Thus, "[running] to the Commission" becomes a claim of innocence and victimization. Reality for women, post-apartheid, had been established. There was no evidence to the contrary.

Due to the media's simulation of reality, all speech is co-opted to lend further evidence for the established message. Thus, in the case of the TRC, contrary to our belief, speech does not equal power; on the contrary, it gives material proof of victimization. That is to say, the only recourse, the only way for women to escape the victim status, was not to appear and therefore not to speak. As Baudrillard explains, "The current argument of the system is to maximize speech, the maximum production of meaning. Thus the strategic resistance is that of the refusal of meaning and of the spoken word" (Simulacra and Simulation 85). Since with every spoken word, women's testimony lends power to the system, defining them as victims of misfortune rather than agents of political crimes, silence becomes a form of power to subvert the media's overproduction, simulation, and dissimulation of information and meaning. ${ }^{7}$

\footnotetext{
${ }^{7}$ Analisa Oboe goes so far as to wonder "whether this insistence on the need to open up, to speak openly, to break the silence, to lift the veil of silence, is not a new violence on women" (68).
} 
The commission eventually began to recognize the lack of women's testimony in regard to rape and torture. Consequently, plans for special commissions for women were proposed. However, not enough women responded to the special commission to receive the reparations provided for people who were defined as having experienced "gross violations of human rights." Most women in the final reports fell under the category "Severe ill-treatment." Again, Baudrillard provides insight: "There is nothing more dissuasive than the accumulation of evidence" (Intelligence of Evil 193). That is, the overproduction of simulated reality is a powerful deterrent. Thus, the special women's commissions were unsuccessful. Few women testified. The women who attended spoke in vague metaphors. ${ }^{8}$ In the end, TRC findings about the human rights violations of women under the apartheid government were deemed inconclusive. With any event covered by the media, the outcome of the event must be considered in relation to media presence. For Baudrillard, "All media and official news service only exist to maintain the illusion of actuality — of the reality of the stakes, of the objectivity of facts" (Simulations 71). To expose the media's use of simulation as false, and the "real" as hyperreal, leaves no way to return to an original real. It is too far removed. There is no longer an unmediated reality. Even events filmed in "real time" are mediated. What we do gain by this analysis, however, is the ability to see the strength in silence.

${ }^{8}$ In an essay proclaiming the defiance in women's special hearing narratives, Oboe argues: "It is perhaps due to this lack of complete trust on the part of women that, at the hearings, the suffering and the horror ... tend to surface as fragmentary and resistant to language. Some of the testimonies were hopelessly disjointed, sometimes incoherent" (66). 
Understanding the overproduction of information leads to understanding silence as a form of resistance to an overproduced "reality."

As I have shown in this dissertation, reading and writing practices have political consequences. This last chapter of my dissertation shows the social and political significance of my theoretical intervention in feminist debates. My work with Baudrillard is meant to challenge the status quo, to challenge reactive responses that continue to reinforce oppressive structures. Grasping this can help open up more creative responses to social problems as well as to literature and theory. The most important thing that I learned in researching the Truth and Reconciliation Commission (TRC) in South Africa is that academic responses tend to lump together disparate historical events no matter where they take place in the world or in what time period, thereby producing readings in which the cause and the effect are always the same. Thus, we either become confused when known solutions to problems like inequality and oppression do not work universally, or we over generalize about events in ways that disempower social groups that do not conform to our tried and true solutions.

My dissertation has asked a different set of questions, questions directed at the structure of western ideology as a whole. Why is it that, in the West, we commonly understand silence as powerlessness? Is it to affirm our own right to know what happened and reinforce our own powers of interpretation? For the South African women's testimonies do not expose their powerlessness before the TRC but rather the powerlessness of the system that claimed to be able to know, and to heal, an entire country. That the system failed to achieve its intended goal in the case of the women who 
came to speak before the commission should clue us to its systemic failings. Yet, true to many historical representations of women, academics tend to attribute this failure to the women themselves: they are naturally silent, naturally shy away from public speech, or are auxiliary to the men who actively fought against apartheid and are conceived as strong, willful, and powerful agents of history. I privilege an approach that challenges the ways in which we come to think of power and the ways in which we come to recycle power structures through the very analyses meant to critique and expose these structures.

My dissertation has shown that what we value as a society often reinforces historical gendered biases and oppression. I promote a reading practice that questions our social responses to women, literature, and political events - that raises academic consciousness about the ways in which representation may unwittingly reinforce the oppression it seeks to relieve by assuming its values and solutions are universal and ahistorical. More specifically, oppression is often reinforced by our systems of value: what we deem to be of political consequence. As such, we deny or devalue alternative responses. The fact that women did not conform to the desired aims of the commission, for example, hurt them monetarily and politically. But, I argue, it hurt these women because their silence posed a threat to the political power being recycled within the structure of the commission itself.

I began this dissertation by noting the renewed interest in Baudrillard by feminist scholars in the past ten years and their nearly universal neglect of his theory of seduction. In my chapter readings I have sought to demonstrate Baudrillard's relevance to feminism and to disclose a long, and often unacknowledged, strand of what I call a "seducing 
feminism," a writing practice that challenges the materialist rationality of Western metaphysics. The point is not to redeem Baudrillard, long dismissed for his dismissal of reality, for feminism, but to rethink the truisms of feminist practice. My readings of feminist theory, women's literature, and the TRC hearings seek to expose the ideologies that inform literary and theoretical representations of women, and to undermine oppressive structures for speaking about women and reality. 


\section{BIBLIOGRAPHY}

Alcoff, Linda. “The Problem of Speaking for Others.” Cultural Critique 20 (1991-1992): 5-32.

Allende, Isabel. The House of Spirits. New York: Bantam, 1993.

Ammons, Elizabeth. Edith Wharton's Argument with America. Atlanta: University of Georgia, 1982.

Barthes, Roland. Mythologies. New York: Noonday Press, 1989.

Bartsch, Ingrid, Carolyn DiPalma, and Laura Sells. "Witnessing the Postmodern Jeremiad: (Mis)Understanding Donna Haraway’s Method of Inquiry." Configurations 9 (2001): 127-164.

Bartkey, Sandra. "Foucault, Femininity, and the Modernization of Patriarchal Power." The Politics of Women's Bodies. Ed. Rose Weitz. London: Oxford, 2003. 25-45.

Baudrillard, Jean. Forget Foucault. Los Angeles: Semiotext(e), 2007.

---. The Intelligence of Evil or the Lucidity Pact. New York: Berg, 2005.

---. "The Masses: The Implosion of the Social in the Media.” New Literary History 16 (1985): 577-589.

---. The Mirror of Production. St. Louis: Telos Press, 1975.

---. The Perfect Crime. New York: Verso, 1996.

---. Seduction. New York: St. Martin's, 1990.

---. Simulacra and Simulation. Ann Arbor: University of Michigan, 1994.

---. Simulations. Cambridge: Semiotext, 1983.

Belsey, Catherine. Critical Practice. London: Methuen, 1980.

Blair, Amy “Misreading The House of Mirth.” American Literature 76 (2004): 149175. 
Boraine, Alex. A Country Unmasked: Inside South Africa's Truth and Reconciliation Commission. Oxford: Oxford UP, 2000.

Bordieu, Pierre. "What Makes a Social Class? On The Theoretical and Practical Existence of Groups." Berkley Journal of Sociology: A Critical Review 32 (1987): $1-17$.

Braidotti, Rosi. "Becoming Woman: Or Sexual Difference Revisited." Theory Culture Society 20 (2003): 43-64.

---. "Comment on Felski's 'The Doxa of Difference': Working through Sexual Difference." Signs 23 (1997): 23-40.

Brevis, Joanna, and Steven Linstead. Sex, Work, and Sex Work: Eroticizing Organization. New York: Routledge, 2003.

Brooke, Stephen. "The Body and Socialism: Dora Russell in the 1920s." Past and Present 189 (2005): 147-177.

Brown, Helen Gurly. Sex and the Single Girl. New York: Random House, 1962.

Browne, Stella. "The Sexual Variety and Variability Among Women and Their Bearing Upon Social Re-construction." The British Society for the Study of Sex Psychology 3 (1915): <http://homepages.primex.co.uk/ lesleyah/variety.htm>.

Bruehl, Elizabeth Young. Freud on Women. New York: W.W. Norton, 1992.

Burke, Carolyn. "Romancing the Philosophers: Luce Irigaray." Seduction and Theory: Readings of Gender, Representation, and Rhetoric. Ed. Dianne Hunter. Champaign: University of Illinois, 1989. 226-240.

Butler, Judith. Bodies that Matter: On the Discursive Limits of Sex. New York: Routledge, 1993.

---. Gender Trouble: Feminism and the Subversion of Identity. New York: Routledge, 1990.

---. Undoing Gender. New York: Routledge, 2004.

Caughie, Pamela L. Virginia Woolf and Postmodernism. Champaign: University of Illinois, 1991. 
Cella, Laurie. “"Narrative Confidence Games' Framing The Spectacle in Gentlemen Prefer Blondes and Night at the Circus." Frontiers: A Journal of Women Studies. 25 (2004): 47-62.

Chow, Karen. “Popular Sexual Knowledges and Women’s Agency in 1920’s England: Marie Stopes's 'Married Love' and E.M. Hull's 'The Sheik."' Feminist Review 63 (1999): 64-87.

Cixous, Hélène. “The Laugh of the Medusa” Signs 1 (1976): 875-893.

Clements, Kendrick A. "The New Era and New Woman: Lou Henry Hoover and 'Feminism's Awkward Age"' Pacific Historical Review 73 (2004): 425-461.

Coetzee, J.M. Foe. New York: Penguin, 1987.

---. Waiting for the Barbarians. New York: Penguin, 1982.

Connor, Liz. The Spectacular Modern Woman: Feminine Visibility in the 1920s. Bloomington: Indiana University, 2004.

Crozier, Ivan. "“All the World's a Stage': Dora Russell, Norman Haire, and the 1929 London World League for Sexual Reform." Journal of the History of Sexuality 12 (2003): 16-37.

Daly, Mary. Gyn/Ecology: The Metaethics of Radical Feminism. Boston: Beacon, 1990.

De Beauvoir, Simone. The Second Sex. 1949. Trans. and ed. by H.M. Parshley. New York: Vintage Books, 1989.

Debord, Guy. Society of the Spectacle. New York: Zone Books, 1995.

Dennett, Mary Ware. The Sex Side of Life: An Explanation for Young People. Astoria: Mary Ware Dennett, 1919.

Derrida, Jacques. "The Animal that Therefore I Am (More to Follow)." Critical Inquiry 28 (2002): 369-418.

Dimock, Wai-Chee. “Debasing Exchange: Edith Wharton's The House of Mirth." PMLA 100 (1985): 783-792.

Dworkin, Andrea. "Pornography, Prostitution, and a Beautiful and Tragic Recent History.” Ed. Christine Spark and Rebecca Whisnant. Melbourne: Spinifex, 2004. 
Erenberg, Lewis A. 'Everybody's Doin' it: Irene and Vernon Castle and the PreWorld War I Dance Craze." Steppin' Out: New York Nightlife and the Transformation of American Culture, 1890-1925. Westport: Greenwood, 1981.

Evans, Martha Noel. "Hysteria and the Seduction of Theory." Seduction and theory: Readings of Gender, Representation, and Rhetoric. Ed. Diane Hunter. Bloomington: University of Illinois, 1989.

Fleissner, Jennifer L. “Is Feminism a Historicism?” Tulsa Studies in Women's Literature 21 (2002): 45-66.

Felman, Shoshana. The Scandal of the Speaking Body: Don Juan with J.L. Austin, or Seduction in Two Languages. Ithaca: Cornell University, 2002.

Felski, Rita. Doing Time: Feminist Theory and Post-Modern Culture. New York: New York University, 2000.

Firestone, Shulamith. The Dialectic of Sex: The Case for Feminist Revolution. New York: Bantam, 1972.

Foucault, Michael. History of Sexuality, Volume 1: An Introduction. New York: Vintage, 1990.

Freedman, Estelle. “The New Woman: Changing Views in the 1920's.” Journal of American History. 61 (1974): 272-393.

Friedan, Betty. The Feminine Mystique. New York: W. W. Norton, 1963.

Frye, Marilyn. The Politics of Reality: Essays in Feminist Theory. Freedom: The Crossing Press, 1983.

Gallop, Jane. The Daughter's Seduction: Feminist Theory and Psychoanalysis. Ithaca: Cornell University, 1984.

---. "French Theory and the Seduction of Feminism." Men in Feminism. New York: Routledge, 1987.

Gandhi, Leela. Postcolonial Theory: An Introduction. New York: Columbia, 1998.

Garcia-Johnson, and Ronie-Richele. "Struggle for Space: Feminism and Freedom in 'The House of Spirits"” Revisita Hispanica Moderna 47 (1994): 184-193).

Gilman, Charlotte Perkins. Woman and Economics. Minneola: Dover, 1998. 
Glyn, Elinor. It and Other Stories. London: Duckworth, 1927.

Goldman, Emma. Red Emma Speaks. New York: Vintage, 1972.

Grace, Victoria. Baudrillard's Challenge: A Feminist Reading. New York: Routledge, 2000.

Haraway, Donna J. Simians, Cyborgs, and Women. New York: Routledge, 1991.

Hawkesworth, Mary E. "Knowers, Knowing, Known: Feminist Theory and Claims of Truth" Signs, 14 (1989): 533-557.

Hegeman, Susan. “Taking Blondes Seriously.” American Literary History 7 (1995): 525554.

Hong Kingston, Maxine. The Woman Warrior: Memoirs of a Childhood Among Ghosts. New York: Vintage, 1989.

It. Dir. Clarence D. Badger. Perf. Clara Bow, Antonio Moreno, and William Austin. Paramount Pictures, 1927. Film.

Irigaray, Luce. This Sex Which is Not One. Ithaca: Cornell University, 1985.

---. Speculum of the Other Woman. Ithaca: Cornell University, 1974.

Jenkins, Ruth Y. "Authorizing Female Voice and Experience: Ghosts and Spirits in Kingston's The Woman Warrior and Allende's The House of Spirits. MELUS 19 (1994): 61-73.

Johnson, Laura K. "Edith Wharton and the Fiction of Marital Unity." Modern Fiction Studies 47 (2001): 948-976.

Johnson, Val Marie. “'The Rest Can Go to the Devil': Macy's Workers negotiate Gender, Sex, and Class in the Progressive Era." Journal of Women's History 19 (2007): $32-57$.

Jones, Ernest. "The Early Development of Female Sexuality." Psychoanalysis and Female Sexuality. Ed. Hendrik Marinus Ruitenbeek. New Haven: College and University Press Services, 1966. 21-35.

Kaplan, Louise J. Female Perversions: The Temptations of Emma Bovary. New Jersey: Jason Aronson Inc., 1997. 
Kassanoff, Jennie A. "Extinction, Taxidermy, Tableaux Vivants: Staging Race and Class in The House of Mirth." PMLA 115 (2000): 60-74.

Kerber, Linda K. “'I Was Appalled': The Invisible Antecedents of Second-Wave Feminism.” Journal of Women's History 14 (2002): 90-101.

Krog, Antjie. Country of My Skull. Johannesburg: Random House, 2002.

La Roux, Madame. The Practice of Classical Palmestry. York Beach: Samuel Wiser, 1993.

Lambert, Deborah G. "The House of Mirth: Readers Respond." Tulsa Studies in Women's Literature 4 (1985): 69-82.

Liscum, Gary and Xaio-Fan Zong. Chinese Medical Palmistry: Health in Your Hand. Boulder: Blue Poppy Press, 2007.

Long Night's Journey Into Day. Dir. Frances Reid and Deborah Hoffman. Iris Films, 2000. Film.

Loos, Anita. Gentlemen Prefer Blondes and But Gentlemen Marry Brunettes. New York: Penguin Classics, 1998.

Lund, Giuliana. "'Healing the Nation': Medicolonial Discourse and the State of Emergency from Apartheid to Truth and Reconciliation." Cultural Critique 54 (2003): 88-119.

Malnig, Julie. "Athena Meets Venus: Visions of Women in Social Dance in the Teens and Early 1920s.” Dance Research Journal 31 (1999): 34-62.

Marshik, Celia. "Publication and 'Public Women': Prostitution and Censorship in Three Novels by Virginia Woolf." Modern Fiction Studies 45 (1999): 853-886.

McEwan, Cheryl. "Building a Postcolonial Archive? Gender, Collective Memory, and Citizenship in Post-apartheid South Africa." Journal of Southern African Studies 29 (2003): 739-757.

Miller, Heather Lee. "Sexologists Examine Lesbians and Prostitutes in the United States, 1840-1940.” NWSA 12 (2000): 67-91.

Meijer, Irene, and Baukje Prins. "How Bodies Come to Matter: An Interview With Judith Butler.” Signs 23 (1998): 275-286. 
Miller, Margaret. "Threads of Identity in Maxine Hong Kingston's Woman Warrior." Biography 6 (1983): 13-33.

Minh-Ha, Trinh T. "Difference: 'A Special Third World Women's Issue.'” Feminist Review 25 (1987): 5-22.

---. Woman Native Other: Writing Postcoloniality and Feminism. Bloomington: Indiana, 1989.

Moi, Toril. Sexual Textual Politics. New York: Routledge, 1985.

Morey, Ann. “'Would You Be Ashamed To Let Them See What You Have Written?' The Gendering of Photoplaywrights 1913-1923." Tulsa Studies in Women's Literature 1 (1998): 83-99.

Moss, Laura. “"Nice Audible Crying”: Editions, Testimonies, and Country of My Skull." Research in African Literatures 37 (2006): 85-103.

Neuhaus, Jessamyn. "The Importance of Being Orgasmic: Gender, Sexuality, and Sex Manuals in the United States, 1920-1963." Journal of the History of Sexuality 9 (2000): 447-473.

---. “Is It Ridiculous for me to Say I Want to Write?': Domestic Humor and Redefining the 1950s Housewife Writer in Fan Mail to Shirley Jackson." Journal of Women's History 21 (2009): 115-137.

Neushul, Peter. "Marie C. Stopes and the Popularization of Birth Control Technology." Technology and Culture 39 (1998): 245-272.

Oboe, Analisa. "The TRC Women's Hearings as Performance and Protest in the New South Africa." Research in African Literatures 38 (2007): 60-76.

Olsen, Tillie. Silences. New York: Feminist Press, 2003.

Orgeron, Marsha. "Making 'It' in Hollywood: Clara Bow, Fandom, and Consumer Culture." Cinema Journal 42 (2003): 76-97.

Paglia, Camille. Sex, Art, and American Culture: Essays. New York: Vintage, 1992.

Parker, Cornelia Stratton. Working With the Working Woman. New York: Harper and Brothers, 1922. 
Parry, Benita. "Speech and Silence in the Fictions of J.M. Coetzee." Writing South Africa: Literature, Apartheid, and Democracy, 1970-1995. Ed. Derek Attridge and Rosemary Jolly. Cambridge: University of Cambridge, 1998

Pawlowski, Merry. "Virginia Woolf's Veil: The Feminist Intellectual and the Organization of Public Space.” Modern Fiction Studies 53 (2007): 722-751.

Peppis, Paul. "Rewriting Sex: Mina Loy, Marie Stopes, and Sexology." Modernism/Modernity 9 (2002): 561-579.

Phillips, James Orchard Halliwell, Popular Rhymes and Nursery Tales: A Sequel to the Nursery Rhymes of England. London: John Russell Smith, 1849.

Restuccia, Francis L. "The Name of the Lily: Edith Wharton's Feminism(s)." Contemporary Literature 28 (1987): 223-238.

Rivière, Joan. "Womanliness as Masquerade" Journal of Psychoanalysis 8 (1929): 303313.

Roach, Joseph. “It.” Theatre Journal 56 (2004): 555-568.

Robinson, Hillary. Reading Art, Reading Irigaray: The Politics of Art By Women. New York: I.B. Taurus, 2006.

Ross, Fiona. Bearing Witness: Women and the Truth and Reconciliation Commission in South Africa. London: Pluto Press. 2003.

Russell, Dora. "Hypatia or Women and Knowledge.” Sexology Uncensored: The Documents of Sexual Science. Ed. Lucy Bland and Laura L Doan. Chicago: University of Chicago, 1999.

Ryan, Patrick A and Sevan G. Terzian. "Our Miss Brooks: Broadcasting Domestic Ideals for the Female Teacher in the Postwar United States." Feminist Formations 21 (2009): 76-100.

Sanger, Alexander. "Eugenics, Race, and Margaret Sanger.” Hypatia (2007): 210-217.

Sanger, Margaret. What Every Girl Should Know. Springfield: United Sales Co, 1920.

Saville, Deborah. "Freud, Flappers and Bohemians: The Influence of Modern Psychological Thought and Social Ideology on Dress, 1910-1923.” Dress USA 30 (2003): 63-79. 
Scanlon, Jennifer. Bad Girls Go Everywhere: The Life of Helen Gurly Brown. New York: Oxford, 2009.

Schneider, Rebecca. The Explicit Body in Performance. New York: Routledge, 1997.

Scott, Joan. "Fantasy Echo: Feminist History and the Construction of Identity." Critical Inquiry 27 (2001): 248-304.

Sedgwick, Eve. Between Men: English Literature and Male Homosocial Desire. New York: Columbia UP, 1985.

Shu, Yuan. "Cultural Politics and Chinese-American Female Subjectivity: Rethinking Kingston's 'Woman Warrior.” MELUS 26 (2001): 199-223.

Sklar, Kathryn Kish. “Organized Womanhood: Archival Sources on Women and Progressive Reform.” The Journal of American History 75 (1988): 176-183.

Spivak, Gayatri Chakravorty. "Can The Subaltern Speak." Marxism and the Interpretation of Culture. London: Macmillan, 1998.

Staveley, Alice. "Marketing Virginia Woolf: Women, War, and Public Relations in Three Guineas." Book History 12 (2009): 295-339.

Stark, Christine, and Rebecca Whisnant. Not for Sale: Feminists Resisting Prostitution and Pornography. Melbourne: Spinifex, 2004.

Stopes, Marie. Contraception (Birth Control): Its Theory History and Practice: A Manual for the Medical and Legal Professions. London: J. Bale, Sons \& Danielsson, 1923.

Tofoletti, Kim. Cyborgs and Barbie Dolls: Feminism, Popular Culture, and the Posthuman Body. New York: I.B. Tauris, 2007.

Tone, Andrea. "Black Market Birth Control: Contraceptive Entrepreneurship and Criminality in the Gilded Age." The Journal of American History 87 (2000): 435459.

Veblen, Thorstein. The Theory of the Leisure Class. New York: Penguin Classics, 1994.

Vint, Sherryl. "“A family of displaced figures': an overview of Donna Haraway." Science Fiction, Film, and Television 1 (2008): 289-301. 
Weinbaum, Alys Eve. "Writing Feminist Genealogy: Charlotte Perkins Gilman, Racial Nationalism, and the Reproduction of Maternalist Feminism." Feminist Studies 27 (2001): 271-302.

Wharton, Edith. The House of Mirth. New York: Barnes and Noble, 1999.

Winterhalter, Teresa. “'What Else Can I Do But Write?' Discursive Disruption and the Ethics of Style in Virginia Woolf's Three Guineas.” Hypatia 18 (2003): 236-257.

Wolff, Cynthia Griffin. "Lily Bart and the Drama of Femininity." American Literary History 6 (1994): 71-87.

Woolf, Virginia. Jacob’s Room New York: Harcourt, 1950.

---. Three Guineas New York: Penguin, 1977.

Wright, Helena Rosa. “The Sex Factor in Marriage.” Sexology Uncensored: The Documents of Sexual Science, ed. Lucy Bland and Laura L Doan. Chicago: University of Chicago, 1999.

Wussow, Helen, "Virginia Woolf and the Problematic Nature of the Photographic Image." Twentieth Century Literature 40 (1994): 1-14.

Yellis, Kenneth A. "Prosperitiy's Child: Some Thoughts on the Flapper." American Quarterly 21 (1969): 44-68. 
VITA

Erin Holliday-Karre was born in Lynchburg, Virginia and raised in Georgetown, South Carolina, Memphis, Tennessee, and Brussels, Belgium. Before attending Loyola University Chicago, she attended the Hunter College, CUNY where she earned a Master of Arts in English in 2005. She also attended the University of Tennessee, Knoxville where she received a Bachelor of Arts in Psychology in 1998.

While at Loyola, Erin was elected Vice President of the Graduate School Advisory Committee where she served as the English department representative for two years. Erin also won the Arthur J. Schmitt dissertation fellowship in 2010 and was a finalist for the U.S. Fulbright Scholarship Program in 2007. Her most rewarding experience was her three years as manager of the Loyola Community Literacy Center, which is a community-outreach service offering free tutoring in English to adult nonreaders, giving them the skills to succeed socially and professionally. 